
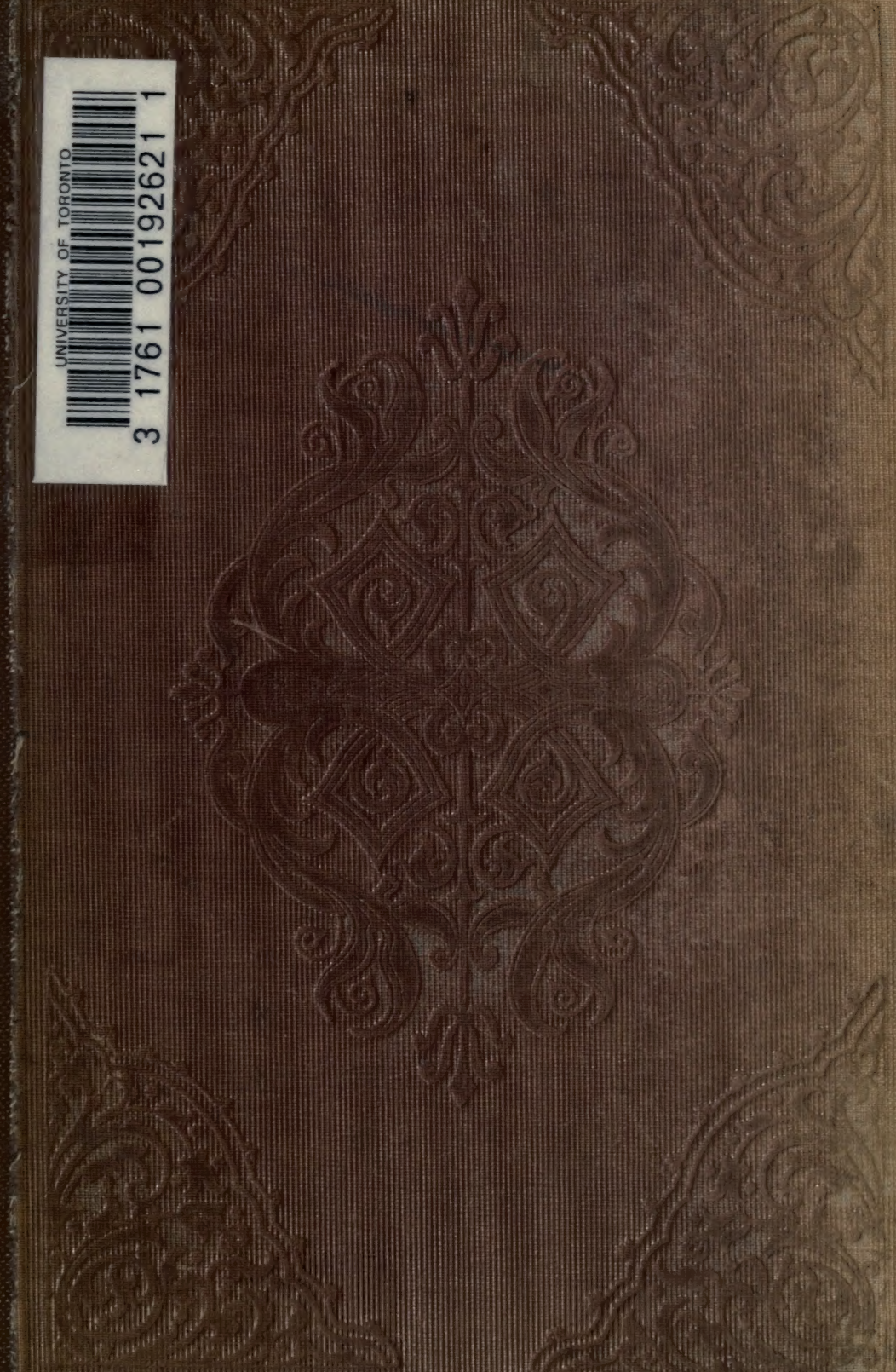


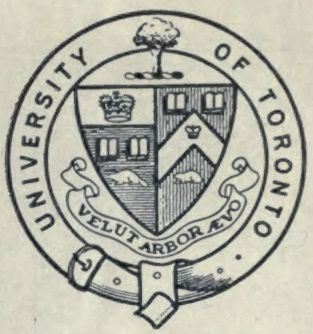

PURCHASED FOR THE

UNIVERSITY OF TORONTO LIBRARY

FROM THE

CANADA COUNCIL SPECIAL GRANT

FOR

HISTORY OF SCIENCE 

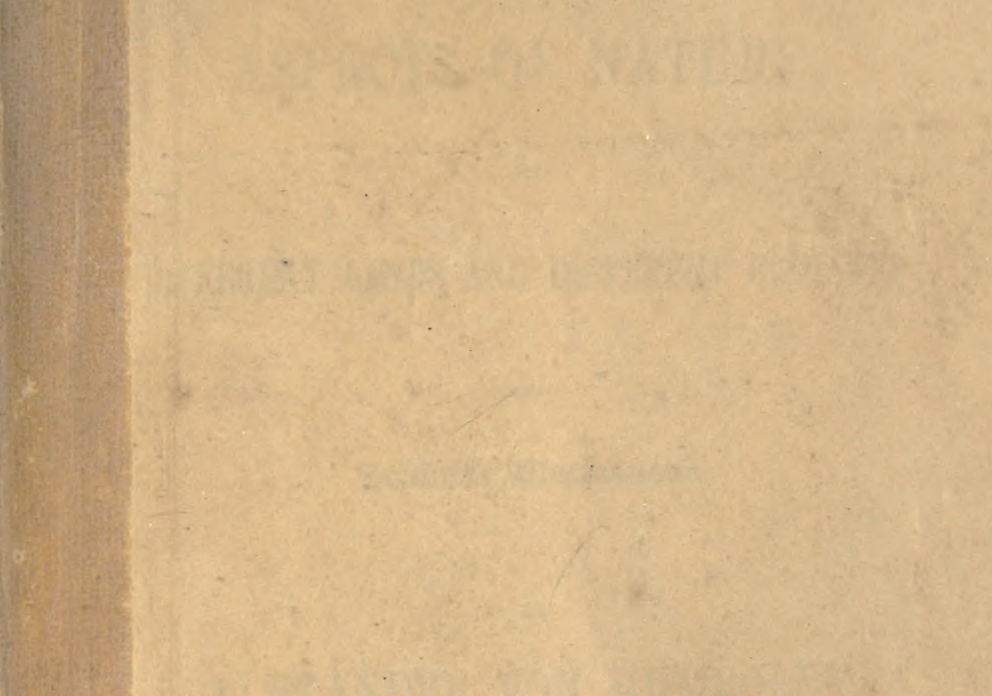



\section{ASPECTS OF NATURE,}

IN

\section{DIFFERENT LANDS AND DIFFERENT CLIMATES;}

WITH

Srientific эelucioations.

\section{BY \\ ALEXANDER VON HUMBOLDT.}

TRANSLATED BY MRS. SABINE.

IN TWO VOLUMES.

VOL. I.

LONDON :

LONGMAN, BROWN, GREEN, AND LONGMANS, PATERXOSTER Row; AND JOHN MURRAY, ALBEMARLE STREET.

1849. 


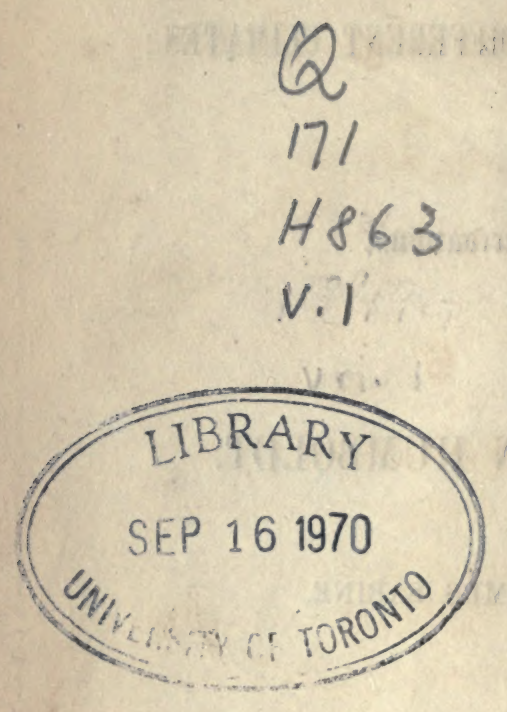




\section{AUTHOR'S PREFACE}

TO THE

\section{FIRST EDITION.}

IT is not without diffidence that I present to the public a series of papers which took their origin in the presence of natural scenes of grandeur or of beauty,-on the Ocean, in the forests of the Orinoco, in the Steppes of Venezuela, and in the mountain wildernesses of Peru and Mexico. Detached fragments were written down on the spot and at the moment, and were afterwards moulded into a whole. The view of Nature on an enlarged scale, the display of the concurrent action of various forces or powers, and the renewal of the enjoyment which the immediate prospect of tropical scenery affords to sensitive minds, are the objects which I have proposed to myself. According to the design of my work, whilst each of the treatises of which it consists should form a whole complete in itself, one common tendency should pervade them all. Such an artistic and VOL. I. 
literary treatment of subjects of natural history is liable to difficulties of composition, notwithstanding the aid which it derives from the power and flexibility of our noble language. The unbounded riches of Nature occasion an accumulation of separate images; and accumulation disturbs the repose and the unity of impression which should belong to the picture. Moreover, when addressing the feelings and imagination, a firm hand is needed to guard the style from degenerating into an undesirable species of poetic prose. But I need not here describe more fully dangers which I fear the following pages will shew I have not always succeeded in avoiding.

Nevertheless, notwithstanding faults which I can more easily perceive than amend, I venture to hope that these descriptions of the varied Aspects which Nature assumes in distant land3, may impart to the reader a portion of that enjoyment which is derived from their immediate contemplation by a mind susceptible of such impressions. As this enjoyment is enhanced by insight into the more hidden connection of the different powers and forces of nature, I have subjoined to each treatise scientific elucidations and additions. 
Throughout the entire work I have sought to indicate the unfailing influence of external nature on the feelings, the moral dispositions, and the destinies of man. To minds oppressed with the cares or the sorrows of life, the soothing influence of the contemplation of nature is peculiarly precious; and to such these pages are more especially dedicated. May they, "escaping from the stormy waves of life," follow me in spirit with willing steps to the recesses of the primeval forests, over the boundless surface of the Steppe, and to the higher ridges of the Audes. To them is addressed the poet's voice, in the sentence of the Chorus-

"Auf den Bergen ist Freiheit! Der Hauch der Grüfte Steigt nicht hinauf in die reinen Lüfte;

Die Welt ist vollkommen überall,

Wo der Mensch nicht hinkommt mit seiner Qual." 



\section{$\triangle$ UTHOR'S PREFACE}

TO THE

\section{SECOND AND THIRD EDITIONS.}

THE twofold aim of the present work (a carefully prepared and executed attempt to enhance the enjoyment of Nature by animated description, and at the same time to increase in proportion to the state of knowledge at the time the reader's insight into the harmonious and concurrent action of different powers and forces of Nature) was pointed out by me nearly half a century ago in the Preface to the First Edition. In so doing, I alluded to the various obstacles which oppose a successful treatment of the subject in the manner designed. The combination of a literary and of a purely scientific object,-the endeavour at once to interest and occupy the imagination, and to enrich the mind with new ideas by the augmentation of knowledge,-renders the due arrangement of the separate parts, and the desired unity of composition, difficult of attainment. Yet, notwithstanding these dis- 
advantages, the public have long regarded my imperfectly executed undertaking with friendly partiality.

The second edition of the "Ansichten der Natur" was prepared by me in Paris in 1826; and at the same time two fresh treatises were added,-one an Essay on the Structure and mode of Action of Volcanoes in different regions of the earth; and the other on the "Vital Power," bearing the title "Lebenskraft, oder der rhodische Genius." During my long stay at Jena, Schiller, in the recollection of his youthful medical studies, loved to converse with me on physiological subjects; and the considerations in which I was then engaged on the muscular and nervous fibres when excited by contact with chemically different substances, often gave a more specific and graver turn to our discourse. The "Rhodian Genius" was written at this time: it appeared first in Schiller's "Horen," a periodical journal; and it was his partiality for this little work which encouraged me to allow it to be reprinted. My brother, in a letter forming part of a collection which has recently been given to the public (Wilhelm von Humboldt's Briefe an eine Freundin, Th. ii. S. 39), touches tenderly on the subject of the memoir in question, but adds at the same time a very just remark : 
PREFACE TO THE SECOND AND THIRD EDITIONS. Xiii

"The development of a physiological idea is the object of the entire treatise; men were fonder at that time than they would now be of such semi-poetic clothing of severe scientific truths."

In my eightieth year, I am still enabled to enjoy the satisfaction of completing a third edition of my work, remoulding it entirely afresh to meet the requirements of the present time. Almost all the scientific Elucidations or Annotations have been either enlarged or replaced by new and more comprehensive ones. I have hoped that these volumes might tend to inspire and cherish a love for the study of Nature, by bringing together in a small space the results of careful observation on the most varied subjects; by showing the importance of exact numerical data, and the use to be made of them by well-considered arrangement and comparison; and by opposing the dogmatic half-knowledge and arrogant scepticism which have long too much prevailed in what are called the higher circles of society.

The expedition made by Ehrenberg, Gustav Rose, and myself, by the command of the Emperor of Russia, in 1829, to Northern Asia (in the Ural and Altai mountains, and on 
the shores of the Caspian Sea), falls between the period of publication of the second and third editions. This expedition has contributed materially to the enlargement of my views in all that regards the form of the surface of the earth, the direction of mountain-chains, the connection of steppes and deserts with each other, and the geographical distribution of plants in relation to ascertained conditions of temperature. The long subsisting want of any accurate knowledge on the subject of the great snow-covered mountain-chains which are situated between the Altai and the Himalaya (i.e. the Thian-schan and the Kuen-lün), and the ill-judged neglect of Chinese authorities, have thrown great obscurity around the geography of Central Asia, and have allowed imagination to be substituted for the results of observation in works which have obtained extensive circulation. In the course of the last few months the hypsometrical comparison of the culminating summits of the two continents has almost unexpectedly received important corrections and additions, of which I hasten to avail myself. (Vol.i.pp.57-58, and 92-93.) The determinations of the heights of two mountains in the eastern chain of the Andes of Bolivia, the Sorata and the Illimani, have been freed from the errors which had placed those mountains above the Chimborazo, but without as yet 
altogether restoring to the latter with certainty its ancient pre-eminence among the snowy summits of the New World. In the Himalaya the recently executed trigonometrical measurement of the Kinchinjinga (28178 English feet) places it next in altitude to the Dhawalagiri, a new and more exact trigonometrical measurement of which has also been recently made.

For the sake of uniformity with the two previous editions of the "Ansichten der Natur," I have given the degrees of temperature in the present work (unless where expressly stated otherwise) in degrees of Reaumur's scale. The linear measures are the old French, in which the toise equals six Parisian feet. The miles are geographical, fifteen to a degree of the equator. The longitudes are reckoned from the Observatory at Paris as a first meridian.

BERLTK, 1849. 


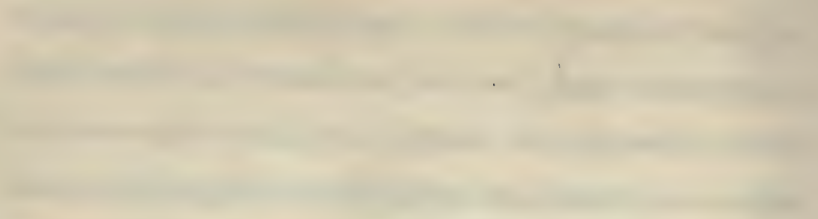

-

$+2$

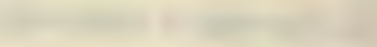

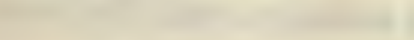
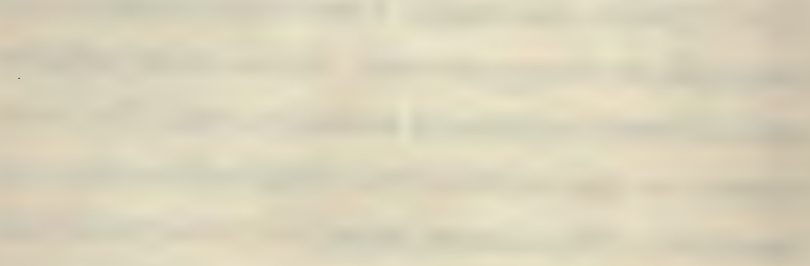


\section{NOTE BY THE TRANSLATOR.}

IN the translation the temperatures are given in degrees of Fahrenheit, retaining at the same time the original figures in Reaumur's scale. In the same manner the measures are given in English feet, generally retaining at the same time the original statements in Parisian or French feet or toises, a desirable precaution where accuracy is important. The miles are given in geographical miles, 60 to a degree, but in this case the original figures have usually been omitted, the conversion being so simple as to render the introduction of error very improbable. In a very few instances "English miles" appear without any farther epithet or explanation; these have been taken by the author from English sources, and may probably signify statute miles. The longitudes from Greenwich are substituted for those from Paris, retaining in addition the original statement in particular cases. 



\section{CONTENTS.}

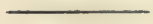

Author's Preface to the First Edition . . . . vii

Author's Preface to the Second and Third Editions . xi

Note by the Translator a . . . . . . . xvii

Steppes and Deserts $\quad . \quad$. . . . . . 1

Annotations and Additions $\quad . \quad$. $\quad . \quad$. 27

Cataracts of the Orinoco $\quad$. . . . . . 207

Annotations and Additions $\quad . \quad$. $\quad . \quad$. 233

Nocturnal Lime of Animals in the Primeval Forest 257

Annotations and Additions $\quad . \quad$. $\quad . \quad$. 273

HYPSOMETRIC ADDENDA . . . . . . . . 277

** For General Summary of the Contents of the First Volume, see page 289. 



\section{STEPPES AND DESERTS.}




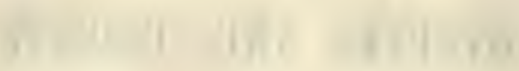




\section{ASPECTS 0F NATURE}

IN

\section{DIFFERENT LANDS AND DIFFERENT CLIMATES.}

STEPPES AND DESERTS.

A WIDELY extended and apparently interminableplain stretches from the southern base of the lofty granitic crest, which, in the youth of our planet, when the Caribbean gulf was formed, braved the invasion of the waters. On quitting the mountain valleys of Caraccas, and the island-studded lake of Tacarigua ( ${ }^{1}$ ) whose surface reflects the stems of plantains and bananas, and on leaving behind him meads adorned with the bright and tender green of the Tahitian sugar cane or the darker verdure of the Cacaa groves, the traveller, looking southward, sees unroll before him Steppes receding until they vanish in the far horizon.

Fresh from the richest luxuriance of organic life, he treads at once the desolate margin of a treeless desert. Neither hill nor cliff rises, like an island in the ocean, to break the uniformity of the boundless plain; only here and there VOL. I, 
broken strata of limestone, several hundred square miles in extent, appear sensibly higher than the adjoining parts. "Banks" ( $\left.{ }^{2}\right)$ is the name given to them by the natives; as if language instinctively recalled the more ancient condition of the globe, when those elevations were shoals, and the Steppes themselves were the bottom of a great Mediterranean sea.

Even at the present time nocturnal illusion still recalls these images of the past. When the rapidly rising and descending constellations illumine the margin of the plain, or when their trembling image is repeated in the lower stratum of undulating vapour, we seem to see before us a shoreless ocean. $\left(^{3}\right)$ Like the ocean, the Steppe fills the mind with the feeling of infinity; and thought, escaping from the visible impressions of space, rises to contemplations of a higher order. Yet the aspect of the clear transparent mirror of the ocean, with its light, curling, gently foaming, sportive waves, cheers the heart like that of a friend; but the Steppe lies stretched before us dead and rigid, like the stony crust ( ${ }^{4}$ ) of a desolated planet.

In every zone nature presents the phenomena of these great plains : in each they have a peculiar physiognomy, determined by diversity of soil, by climate, and by elevation above the level of the sea.

In northern Europe, the Heaths, which, covered with a single race of plants repelling all others, extend from the point of Jutland to the mouth of the Scheldt, may be regarded as true Steppes,- - but Steppes of small extent and hilly surface, if compared with the Llanos and Pampas of 
South America, or even with the Prairies of the Missouri (5) and the Barrens of the Coppermine river, where range countless herds of the shaggy buffalo and musk ox.

A grander and severer aspect characterises the plains of the interior of Africa. Like the wide expanse of the Pacific Ocean, it is only in recent times that attempts have been made to explore them thoroughly. They are parts of a sea of sand, which, stretching eastward, separates fruitful regions from each other, or encloses them like islands; as where the Desert, near the basaltic mountains of Harudsh, $\left({ }^{6}\right)$ surrounds the Oasis of Siwah rich in date trees, and in which the ruins of the temple of Ammon mark the venerable site of an ancient civilisation. Neither dew nor rain bathe these desolate plains, or develope on their glowing surface the germs of vegetable life; for heated columns of air, every where ascending, dissolve the vapours, and disperse each swiftly vanishing cloud.

Where the Desert approaches the Atlantic Ocean, as between the Wadi Nun and Cape Blanco, the moist sea air pours in to supply the void left by these upward currents. The mariner, steering towards the mouth of the Gambia through a sea covered with weed, when suddenly deserted by the east trade wind of the tropics, ( 7 infers the vicinity of the widely extended heat-radiating desert. Herds of antelopes and swift-footed ostriches roam through these vast regions; but, with the exception of the watered Oases or islands in the sea of sand, some groups of which have recently been discovered, and whose verdant shores are frequented by nomade Tibbos and Tuaricks, $\left(^{8}\right)$ the African 
Desert must be regarded as uninhabitable by man. The more civilised nations who dwell on its borders only venture to enter it periodically. By trading routes, which have remained unaltered for thousands of years, caravans traverse the long distance from Tafilet to Timbuctoo, and from Moorzouk to Bornou; adventurous undertakings, the possibility of which depends upon the existence of the camel, the "ship of the desert," ( $\left.{ }^{9}\right)$ as it is called in the traditionary language of the eastern world.

These African plains occupy an extent nearly three times as great as that of the neighbouring Mediterranean sea. They are situated partly within, and partly in the vicinity of the tropics; and on this situation their peculiar character depends. In the eastern part of the old continent, the same geognostic phenomenon occurs in the temperate zone. On the plateaux of central Asia, between the gold mountains or the Altai and the Kuen-lun, $\left({ }^{10}\right)$ from the Chinese wall to beyond the Celestial mountains, and towards the sea of Aral, there extend, through a length of many thousand miles, the most vast, if not the most elevated, Steppes on the surface of the globe. I have myself had the opportunity, fully thirty years after my South American journey, of visiting a portion of them ; namely, the Calmuck Kirghis Steppes between the Don, the Volga, the Caspian, and the Chinese lake Dsaisang, being an extent of almost 2800 geographical miles.

These Asiatic Steppes, which are sometimes hilly and sometimes interrupted by pine forests, possess (dispersed over tnem in groups) a far more varied vegetation than that 
of the Llanos and Pampas of Caraccas and Buenos Ayres. The finest part of these plains, which is inhabited by Asiatic pastoral tribes, is adorned with low bushes of luxuriant white-blossomed Rosaceæ, and with Fritillarias, Tulips, and Cypripedias.

As the torrid zone is characterised on the whole by a disposition in all vegetation to become arborescent, so some of the Asiatic Steppes in the temperate zone are characterised by the great height attained by flowering herbaceous plants, Saussureas and other Synantheræ, and Papilionaceæ especially a host of species of Astragalus. In traversing pathless portions of these Steppes, the traveiler, seated in the low Tartar carriages, sees the thickly crowded plants bend beneath the wheels, but without rising up cannot look around him to see the direction in which he is moving. Some of the Asiatic Steppes are grassy plains; others are covered with succulent, evergreen, articulated soda plants : many glisten from a distance with flakes of exuded salt which cover the clayey soil, not unlike in appearance to fresh fallen snow.

These Mongolian and Tartarian Steppes, interrupted frequently by mountainous features, divide the very ancient civilisation of Thibet and Hindostan from the rude nations of Northern Asia. They have in various ways exercised an important influence on the changeful destinies of man. They have compressed the population towards the south, and have tended, more than the Himalaya, or than the snowy mountains of Srinagur and Ghorka, to impede the intercourse of nations, and to place permanent limits to the extension 
of milder manners, and of artistic and intellectual cultivation in northern Asia.

But, in the history of the past, it is not alone as an opposing barrier that we must regard the plains of Central Asia : more than once they have proved the source from whence devastation has spread over distant lands. The pastoral nations of these Steppes,-Moguls, Getæ, Alani, and Usuni,-have shaken the world. As in the course of past ages, early intellectual culture has come like the cheering light of the sun from the East, so, at a later period, from the same direction barbaric rudeness has threatened to overspread and involve Europe in darkness. A brown pastoral race, ( $\left.{ }^{11}\right)$ of Tukiuish or Turkish descent, the Hiongnu, dwelling in tents of skins, inhabited the elevated Steppe of Gobi. Long terrible to the Chinese power, a part of this tribe was driven back into Central Asia. The shock or impulse thus given passed from nation to nation, until it reached the ancient land of the Finns, near the Ural mountains. From thence, Huns, Avari, Ghazarés, and various admixtures of Asiatic races, broke forth. Armies of Huns appeared successively on the Volga, in Pannonia, on the Marne, and on the Po, desolating those fair and fertile fields which, since the time of Antenor, civilised man had adorned with monument after monument. Thus went forth from the Mongolian deserts a deadly blast, which withered on Cisalpine ground the tender long-cherished flower of art.

From the salt Steppes of Asia, from the European Heaths smiling in summer with their purple blossoms rich in honey, 
and from the arid Deserts of Africa devoid of all vegetation, let us now return to those South American plains of which I have already began to trace the picture, albeit in rude outlines.

The interest which this picture can offer to the beholder is, however, exclusively that of pure nature. Here no Oasis recalls the memory of earlier inhabitants; no carved stone, $\left.{ }^{12}\right)$ no ruined building, no fruit tree once the care of the cultivator but now wild, speaks of the art or industry of former generations. As if estranged from the destinies of mankind, and riveting attention solely to the present moment, this corner of the earth appears as a wild theatre for the free development of animal and vegetable life.

The Steppe extends from the Caraccas coast chain to the forests of Guiana, and from the snowy mountains of Merida (on the slope of which the Natron Lake Urao is an object of superstitious veneration to the natives,) to the great delta formed by the Orinoco at its mouth. To the south-west a branch is prolonged, like an arm of the sea, $\left({ }^{13}\right)$ beyond the banks of the Meta and Vichada to the unvisited sources of the Guaviare, and to the lonely mountain to which the excited fancy of the Spanish soldiery gave the name of Paramo de la Suma Paz-the seat of perfect peace.

This Steppe occupies a space of 16,000 (256,000 English) square miles. It has often been erroneously deseribed as running uninterruptedly, and with an equal breadth, to the straits of Magellan, forgetting the forest-covered plain of the Amazons which intervenes between the grassy Steppes of the Apure and those of the river Plate. The Andes of 
Cochabamba, and the Brazilian group of mountains, send forth, between the province of Chiquitos and the isthmus of Villabella, some detached spurs, which advance, as it were, to meet each other. (14) A narrow plain connects the forest lands of the Amazons with the Pampas of Buenos Ayres. The latter far surpass the Llanos of Venezuela in area; and their extent is so great that while their northern margin is bordered by palm trees, their southern extremity is almost continually covered with ice.

The Tuyu, which resembles the Cassowary (the Struthio rhea), is peculiar to these Pampas, which are also the haunt of troops of dogs (15) descended from those introduced by the colonists, but which have become completely wild, dwelling together in subterranean hollows, and often attacking with blood-thirsty rage the human race whom their progenitors served and defended.

Like the greater portion of the desert of Sahara, $\left({ }^{16}\right)$ the northernmost of the South American plains, the Llanos, are in the torrid zone: during one half of the year they are desolate, like the Lybian sandy waste; during the other, they appear as a grassy plain, resembling many of the Steppes of Central Asia. (17)

It is a highly interesting though difficult task of general geography to compare the natural conditions of distant regions, and to represent by a few traits the results of this comparison. The causes which lessen both heat and dryness in the New World (18) are manifold, and in some respects as yet only partially understood. Amongst these may be classed the narrowness and deep indentation of the 
American land in the northern part of the torrid zone, where consequently the atmosphere, resting on a liquid base, does not present so heated an ascending current; - the extension of the continent towards the poles;-the expanse of ocean over which the trade-winds sweep freely, acquiring thereby a cooler temperature ; - the flatness of the eastern coasts ; currents of cold sea-water from the antarctic regions, which, coming from the south-west to the north-east, first strike the coast of Chili in the parallel of $35^{\circ}$ south latitude, and advance along the coast of Peru as far north as Cape Pariña, and then turn suddenly to the west; - the numerous lofty mountain chains rich in springs, and whose snow-clad summits, rising high above all the strata of clouds, cause descending currents of cold air to roll down their declivities; - the abundance of rivers of enormous breadth, which, after many windings, seek the most distant coast; -Steppes which from not being sandy are less susceptible of acquiring a high degree of heat,-impenetrable forests occupying the alluvial plains situated immediately beneath the equator, protecting with their shade the soil beneath from the direct influence of the sunbeams, and exhaling in the interior of the country at a great distance from the mountains and from the ocean vast quantities of moisture, partly imbibed and partly elaborated:-all these circumstances afford to the flat part of America a climate which by its humidity and coolness contrasts wonderfully with that of Africa. It is to the same causes that we are to attribute the luxuriant vegetation, the magnificent forests, and that abundant leafiness by which the new continent is peculiarly characterised. 
If, therefore, one side of our planet has a moister atmosphere than the other, the consideration of the present condition of things is amply sufficient to explain the problem presented by this inequality. The physical inquirer needs not to clothe the explanation of these phenomena in a mantle of geological myths. He needs not to assume that on our planet the harmonious reconciliation of the destructive conflict of the elements took place at different epochs in the eastern and the western hemispheres; or that America emerged later than the other parts of the globe from the chaotic watery covering, $\left({ }^{19}\right)$ as an island of swamps and marshes tenanted by alligators and serpents.

There is, indeed, a striking similarity between South America and the southern peninsula of the old continent in the form of the outline and in the direction of the coasts; but the nature of the soil, and the relative position of the neighbouring masses of land, produce in Africa that extraordinary aridity which over an immense area checks the development of organic life. Four-fifths of South America are situated on the southern side of the equator; or in a hemisphere which from the greater proportion of sea and from other causes is cooler and moister than our northern half of the globe, $\left({ }^{20}\right)$ to which the larger part of Africa belongs. The breadth of the South American Steppe, measured from east to west, is only a third of that of the African Desert. The Llanos receive the influence of the tropical sea wind, while the African Deserts, being situated in the same zone of latitude as Arabia and the south of Persia, are in contact with strata of air which have blown 
over warm heat-radiating continents. The venerable and only lately appreciated father of history, Herodotus, in tne true spirit of an enlarged view of nature, described the Deserts of northern Africa, of Yemen, of Kerman and Mekran (the Gedrosia of the Greeks), and even as far as Moultan, as forming a single connected sea of sand. ( ${ }^{21}$ )

In addition to the action of these hot winds, there is (so far as we know) an absence or comparative paucity in Africa of large rivers, of widely extended forests producing coolness and exhaling moisture, and of lofty mountains. Of mountains covered with perpetual snow, we know only the western part of the Atlas, $\left({ }^{22}\right)$ whose narrow range, seen in profile from the Atlantic, appeared to the ancient navigaters when sailing along the coast as a single detached lofty sky-supporting mount. The eastern prolongation of the chain extends nearly to Dakul, where Carthage, once mistress of the seas, now lies in mouldering ruins. As forming a long extended coast-chain, or Grtulian rampart, the effect of the Atlas range is to intercept the cool north breezes, and the vapours which ascend from the Mediterranean.

The Mountains of the Moon, Djebel-al-Komr, (23) (fabulously represented as forming part of a mountainous parallel extending from the high plateaux of Habesh, an African Quito, to the sources of the Senegal), were supposed to rise above the limit of perpetual snow. The Cordillera of Lupata, which extends along the eastern coast of Mozambique and Monomotapa, as the Andes along the 
western coast of Peru, is believed to be covered with perpetual snow in the gold districts of Machinga and Mocanga. But all these mountains, with the abundant waters to which they give rise, are far remote from the immense Desert which stretches from the southern declivity of the Atlas to the Niger.

Possibly, however, all the causes of heat and dryness which have been enumerated may have been insufficient to transform such considerable parts of the African plains into a dreadful desert, without the concurrence of some revolution of nature,-such, for instance, as an irruption of the ocean, whereby these flat regions may have been despoiled of their coating of vegetable soil, as well as of the plants which it nourished. Profound obscurity veils the period of such an event, and the force which determined the irruption. Perhaps it may have been caused by the great "rotatory current" $\left({ }^{24}\right)$ which sends the warmer water of the Mexican gulf over the banks of Newfoundland and to the shores of the old continent, and causes West India cocoa-nuts' and other tropical fruits to reach the coasts of Ireland and Norway. There is still at least at the present time, an arm of this current directed from the Azores to the south-east, which sometimes produces disasters by carrying ships upon the west coast of Africa, which it strikes at a part lined by sand-hills. Other sea coasts (I particularly recall that of Peru between Amotape and Coquimbo) shew that in these hot regions of the earth, where rain never falls and where neither Lecideas nor other Lichens ${ }^{(25)}$ germinate, centuries 
and perhaps thousands of years may elapse before the moveable sand can afford to the roots of plants a secure holding place.

These considerations are sufficient to explain why, with an external similarity of form, Africa and South America present so marked a difference of character both in respect to climate and to vegetation. But although the South American Steppe is covered with a thin coating of mould or fertile earth, and although it is periodically bathed by rains, and becomes covered at such seasons with luxuriantly sprouting herbage, yet it never could attract the surrounding nations or tribes to forsake the beautiful mountain valleys of Caraccas, the margin of the sea, or the wooded banks of the Orinoco, for the treeless and springless wilderness; and thus, previous to the arrival of European and African settlers, the Steppe was almost entirely devoid of human inhabitants.

The Llanos are, indeed, well suited to the rearing of cattle, but the care of animals yielding milk $\left({ }^{26}\right)$ was almost unknown to the original inhabitants of the New Continent. Hardly any of the American tribes have ever availed themselves of the advantages which nature offered them in this respect. The American race (which, with the exception of the Esquimaux, is one and the same from $65^{\circ}$ North to $55^{\circ}$ South latitude), has not passed from the state of hunters to that of cultivators of the soil through the intermediate stage of a pastoral life. Two kinds of native cattle (the Buffalo and the Musk Ox) feed in the northern prairies of western Canada and the plains of arctic America, in Quivira, and 
around the colossal ruins of the Aztec fortress which rises in the wilderness, like an American Palmyra, on the solitary banks of the Gila. The long-horned Rocky Mountain Sheep abounds on the arid limestone rocks of California. The Vicunas, Huanacos, Alpacas, and Lamas, belong to South America; but the two first named of all these useful animals, i.e., the Buffalo and the Musk Ox, have retained their natural freedom for two thousand years, and the use of milk and cheese, like the possession and cultivation of farinaceous grasses, (27) has remained a distinguishing characteristic of the nations of the old world.

If some of the latter have crossed from northern Asia to the west coast of America, and if, keeping by preference to the cooler mountain regions, $\left({ }^{28}\right)$ they have followed the lofty ridge of the Andes towards the south, their migration must have taken place by ways in which they could not be accompanied by their flocks and herds, or bring with them the cultivation of corn. When the long shaken empire of the Hiongnu fell, may we conjecture that the movement of this powerful tribe may also have occasioned in the north-east of China and in Corea a shock and an impulse which may have caused civilized Asiatics to pass over into the new continent? If such a migration had consisted of inhabitants of the Steppes in which agriculture was not pursued, this hazardous hypothesis (which has hitherto been but little favoured by the comparison of languages) would at least explain the striking absence of the Cereals in America. Possibly one of those Asiatic priestly colonies whom mystic dreams sometimes impelled to embark in long voyages, (of which 
the history of the peopling of Japan (29) in the time of Thsinchi-huang-ti offers a memorable example), may have been driven by storms to the coasts of New California.

If, then, pastoral life, that beneficent middle stage which attaches nomadic hunting hordes to desirable pastures and prepares them, as it were, for agriculture, has remained unknown to the aboriginal nations of America, this circumstance sufficiently explains the absence of human inhabitants in the South American Steppes. This absence has allowed the freest scope for the abundant development of the most varied forms of animal life; a development limited only by their mutual pressure, and similar to that of vegetable life in the forests of the Orinoco, where the Hymenæa and the gigantic laurel are never exposed to the destructive hand of man, but only to the pressure of the luxuriant climbers which twine around their massive trnnks. Agoutis, small spotted antelopes, cuirassed armadilloes, which, like rats, startle the hare in its subterranean holes, herds of lazy chiguires, beautifully striped viverræ which poison the air with their odour, the large maneless lion, spotted jaguars (often called tigers) strong enough to drag away a young bull after killing him; - these and many other forms of animal life $\left({ }^{30}\right)$ wander through the treeless plain.

Thus almost exclusively inhabited by these wild animals, the Steppe would offer little attraction or means of subsistence to those nomadic native hordes, who, like the Asiatics of Hindostan, prefer vegetable nutriment, if it were not for the occasional presence of single individuals of the fan palm, the Mauritia. The benefits of this life-supporting 
tree are widely celebrated; it alone, from the mouth of the Orinoco to north of the Sierra de Imataca, feeds the unsubdued nation of the Guaranis. ( ${ }^{31}$ ) When this people were more numerous and lived in closer contiguity, not only did they support their huts on the cut trunks of palm trees as pillars on which rested a scaffolding forming the floor, but they also, it is said, twined from the leaf-stalks of the Mauritia cords and mats, which, skilfully interwoven and suspended from stem to stem, enabled them in the rainy season, when the Delta is overflowed, to live in the trees like the apes. The floor of these raised cottages is partly covered with a coating of damp clay, on which the women make fires for household purposes, - the flames appearing at night from the river to be suspended high in air. The Guaranis still owe the preservation of their physical, and perhaps also their moral, independence, to the half-submerged, marshy soil over which they move with a light and rapid step, and to their elevated dwellings in the trees, - a habitation never likely to be chosen from motives of religious enthusiasm by an American Stylites. (22) But the Mauritia affords to the Guaranis not merely a secure dwelling-place, but also various kinds of food. Before the flower of the male palm tree breaks through its tender sheath, and only at that period of vegetable metamorphosis, the pith of the stem of the tree contains a meal resembling sago, which, like the farina of the jatropha root, is dried in thin breadlike slices. The fermented juice of the tree forms the sweet intoxicating palm wine of the Guaranis. The scaly fruits, which resemble in their appearance reddish fir cones, afford, 
like the plaintain and almost all tropical fruits, a different kind of nutriment, according as they are eaten after their saccharine substance is fully developed, or in their earlier or more farinaceous state. Thus in the lowest stage of man's intellectual development, we find the existence of an entire people bound up with that of a single tree; like the insect which lives exclusively on a single part of a particular flower.

Since the discovery of the New Continent, the Llanos have become habitable to men. In order to facilitate communication between the Orinoco country and the coasts, towns have been built here and there on the banks of the streams which flow through the Steppes. ( ${ }^{33}$ ) The rearing of cattle has began over all parts of these vast regions. Huts, formed of reeds tied together with thongs and covered with skins, are placed at distances of a day's journey from each other; numberless herds of oxen, horses, and mules, estimated at the peaceful epoch of my journey at a million and a half, roam over the Steppe. The immense multiplication of these animals, originally brought by man from the Old Continent, is the more remarkable from the number of dangers with which they have to contend.

When, under the vertical rays of the never-clouded sun, the carbonized turfy covering falls into dust, the indurated soil cracks asunder as if from the shock of an earthquake. If at such times two opposing currents of air, whose conflict produces a rotatory motion, come in contact with the soil, the plain assumes a strange and singular aspect. Like conical-shaped clouds $\left({ }^{34}\right)$ the points of which descend

VOL. I. 
to the earth, the sand rises through the rarified air in the electrically charged centre of the whirling current; resembling the loud waterspout dreaded by the experienced mariner. The lowering sky sheds a dim, almost strawcoloured light on the desolate plain. The horizon draws suddenly nearer; the Steppe seems to contract, and with it the heart of the wanderer. The hot dusty particles which fill the air increase its suffocating heat, $\left({ }^{35}\right)$ and the east wind, blowing over the long-heated soil, brings with it no refreshment, but rather a still more burning glow. The pools which the yellow fading branches of the fan palm had protected from evaporation now gradually disappear. As in the icy north the animals become torpid with cold, so here, under the influence of the parching drought, the crocodile and the boa become motionless and fall asleep, deeply buried in the dry mud. Every where the death-threatening drought prevails, and yet, by the play of the refracted rays of light producing the phenomenon of the mirage, the thirsty traveller is every where pursued by the illusive image of a cool rippling watery mirror. $\left({ }^{36}\right)$ The distant palm bush apparently raised by the influence of the contact of unequally heated and therefore unequally dense strata of air, hovers above the ground, from which it is separated by a narrow intervening margin. Half concealed by the dark clouds of dust, restless with the pain of thirst and hunger, the horses and cattle roam around, the cattle lowing dismally, and the horses stretching out their long necks and snuffing the wind, if haply a moister current may betray the neighbourhood of a not wholly dried up pool. More saga- 
cious and cunning, the mule seeks a different mode of alleviating his thirst. The ribbed and spherical meloncactus $\left({ }^{37}\right)$ conceals under its prickly envelope a watery pith. The mule first strikes the prickles aside with his fore feet, and then ventures warily to approach his lips to the plant and drink the cool juice. But resort to this vegetable fountain is not always without danger, and one sees many animals that have been lamed by the prickles of the cactus.

When the burning heat of the day is followed by the coolness of the night, which in these latitudes is always of the same length, even then the horses and cattle cannot enjoy repose. Enormous bats suck their blood like vampires during their sleep, or attach themselves to their backs, causing festering wounds, in which musquitoes, hippobosces, and a host of stinging insects, niche themselves. Thus the animals lead a painful life during the season when, under the fierce glow of the sun, the soil is deprived of its moisture. At length, after the long drought, the welcome season of the rain arrives; and then how suddenly is the scene changed! $\left({ }^{38}\right)$ The deep blue of the hitherto perpetually cloudless sky becomes lighter; at night the dark space in the constellation of the Southern Cross is hardly distinguishable ; the soft phosphorescent light of the Magellanic clouds fades away; even the stars in Aquila and Ophiucus in the zenith shine with a trembling and less planetary light. A single cloud appears in the south, like a distant mountain, rising perpendicularly from the horizon. Gradually the increasing vapours spread like mist over the sky, and now the distant thunder ushers in the life-restoring 
rain. Hardly has the surface of the earth received the refreshing moisture, before the previously barren Steppe begins to exhale sweet odours, and to clothe itself with Kyllingias, the many panicules of the Paspalum, and a variety of grasses. The herbaceous mimosas, with renewed sensibility to the influence of light, unfold their drooping slumbering leaves to greet the rising sun; and the early song of birds, and the opening blossoms of the water plants, join to salute the morning. The horses and cattle now graze in full enjoyment of life. The tall springing grass hides the beautifully spotted jaguar, who lurking in safe concealment, and measuring carefully the distance of a single bound, springs, cat-like, as the Asiatic tiger, on his passing prey.

Sometimes, (so the Aborigines relate), on the margin of the swamps the moistened clay is seen to blister and rise slowly in a kind of mound; then with a violent noise, like. the outbreak of a small mud volcano, the heaped-up earth is cast high into the air. The beholder acquainted with the meaning of this spectacle flies, for he knows there will issue forth a gigantic water-snake or a scaly crocodile, awakened from a torpid state ( $\left.{ }^{39}\right)$ by the first fall of rain.

The rivers which bound the plain to the south, the Arauca, Apure, and Payara, become gradually swollen; and now nature constrains the same animals, who in the first half of the year panted with thirst on the dry and dusty soil, to adopt an amphibious life. A portion of the Steppe now presents the aspect of a vast inland sea. $\left({ }^{40}\right)$ The brood mares retire with their foals to the higher banks, which stand like islands above the surface of the lake. 
Every day the space remaining dry becomes smaller. The animals, crowded together, swim about for hours in search of other pasture, and feed sparingly on the tops of the flowering grasses rising above the seething surface of the dark-coloured water. Many foals are drowned, and many are surprised by the crocodiles, killed by a stroke of their powerful notched tails, and devoured. It is not a rare thing to see the marks of the pointed teeth of these monsters on the legs of the horses and cattle who have narrowly escaped from their blood-thirsty jaws. Such a sight reminds the thoughtful observer involuntarily of the capability of conforming to the most varied circumstances, with which the all-providing Author of Nature has endowed certain animals and plants.

The ox and the horse, like the farinaceous cerealia, have followed man over the whole surface of the globe, from India to Northern Siberia, from the Ganges to the River Plate, from the African sea shore to the mountain plateau of Antisana, ( ${ }^{41}$ ) which is higher than the summit of the Peak of Teneriffe. The ox wearied from the plough reposes, sheltered from the noontide sun in one country by the quivering shadow of the northern birch, and in another by the date palm. The same species which, in the east of Europe, has to encounter the attacks of bears and wolves, is exposed in other regions to the assaults of tigers and crocodiles.

But the crocodile and jaguar are not the only assailants of the South American horses; they have also a dangerous enemy among fishes. The marshy waters of Bera and 
Rastro $\left({ }^{42}\right)$ are filled with numberless electric eels, which can at pleasure send a powerful discharge from any part of their slimy yellow spotted bodies. These gymnoti are from five to six feet in length, and are powerful enough to kill the largest animals when they discharge their nervous organs at once in a favourable direction.

The route from Uritucu through the Steppe was formerly obliged to be changed, because the gymnoti had increased to such numbers in a small stream that in crossing it many horses were drowned every year, either from the effects of the shocks they received, or from fright. All other fishes fly the vicinity of these formidable eels. Even the fisherman angling from the high bank fears lest the damp line should convey the shock to him from a distance. Thus, in these regions, electric fire breaks forth from the bosom of the waters.

The capture of the gymnoti affords a picturesque spectacle. Mules and horses are driven into a marsh which is closely surrounded by Indians, until the unwonted noise and disturbance induce the pugnacious fish to begin an attack. One sees them swimming about like serpents, and trying cunningly to glide under the bellies of the horses. Many of these are stunned by the force of the invisible blows; others, with manes standing on end, foaming and with wild terror sparkling in their eyes, try to fly from the raging tempest. But the Indians, armed with long poles of bamboo, drive them back into the middle of the pool. Gradually the fury of the unequal strife begins to slacken. Like clouds which have discharged their electricity, the 
wearied fish begin to disperse; long repose and abundant food are required to replace the galvanic force which they have expended. Their shocks become gradually weaker and weaker. Terrified by the noise of the trampling horses, they timidly approach the bank, where they are wounded by harpoons, and cautiously drawn on shore by non-conducting pieces of dry wood.

Such is the extraordinary battle between horses and fish. That which forms the invisible but living weapon of this electric eel ; - that which, awakened by the contact of moist dissimilar particles, $\left({ }^{43}\right)$ circulates through all the organs of plants and animals; - that which, flashing from the thunder cloud, illumines the wide skyey canopy; - that which draws iron to iron and directs the silent recurring march of the guiding needle;-all, like the several hues of the divided ray of light, flow from one source; and all blend again together in one perpetually, every where diffused, force or power.

I might here close the hazardous attempt to trace a picture of nature such as she shows herself in the Steppes. But as on the ocean fancy not unwillingly dwells awhile on the image of its distant shores, so, before the wide plain disappears from our view, let us cast a rapid glance at the regions by which the Steppes are bounded.

The Northern Desert of Africa divides two races of men who belong originally to the same part of the globe, and whose unreconciled discord appears as ancient as the mythus of Osiris and Typhon. $\left({ }^{44}\right)$ North of the Atlas there dwell nations with long and straight hair, of sallow complexion and 
Caucasian features. On the south of the Senegal, towards Soudan, live hordes of negroes in many different stages of civilization. In Central Asia, the Mongolian Steppe divides Siberian barbarism from the ancient civilisation of the peninsula of India.

The South American Steppes form the boundary of a partial European cultivation. ${ }^{45}$ ) To the north, between the mountains of Venezuela and the Caribbean sea, we find commercial cities, neat villages, and carefully cultivated fields. Even the love of art and scientific culture, together with the noble desire of civil freedom, have long been awakened there. Towards the south the Steppe terminates in a savage wilderness. Forests, the growth of thousands of years, fill with their impenetrable fastnesses the humid regions between the Orinoco and the Amazons. Massive leaden-coloured granite rocks (46) narrow the bed of the foaming rivers. Mountains and forests resound with the thunder of the falling waters, with the roar of the tiger-like jaguar, and with the melancholy rain-announcing howlings of the bearded apes. $\left({ }^{47}\right)$

Where a sand-bank is left dry by the shallow current, the unwieldly crocodiles lie, with open jaws, as motionless as pieces of rock and often covered with birds. ( ${ }^{48}$ ) The boa serpent, his body marked like a chess-board, coiled up, his tail wound round the branch of a tree, lies lurking on the bank secure of his prey; he marks the young bull or some feebler inhabitant of the forest as it fords the stream, and swiftly uncoiling seizes the victim, and covering it with mucus forces it laboriously down his swelling throat. $\left({ }^{49}\right)$ 
In the midst of this grand and savage nature live many tribes of men, isolated from each other by the extraordinary diversity of their languages : some are nomadic, wholly unacquainted with agriculture, and using ants, gums, and earth as food ( $\left.{ }^{50}\right)$; these, as the Otomacs and Jarures, seem a kind of outcasts from humanity : others, like the Maquiritares and Macos, are settled, more intelligent and of milder manners, and live on fruits which they have themselves reared.

Large spaces between the Cassiquiare and the Atabapo are only inhabited by the tapir and the social apes, and are wholly destitute of human beings. Figures graven on the rocks $\left({ }^{51}\right)$ shew that even these deserts were once the seat of some degree of intellectual cultivation. They bear witness to the changeful destinies of man, as do the unequally developed flexible languages; which latter belong to the oldest and most imperishable class of historic memorials.

But as in the Steppe tigers and crocodiles fight with horses and cattle, so in the forests on its borders, in the wildernesses of Guiana, man is ever armed against man. Some tribes drink with unnatural thirst the blood of their enemies; others apparently weaponless and yet prepared for murder ( ${ }^{52}$ ) kill with a poisoned thumb-nail. The weaker hordes, when they have to pass along the sandy margin of the rivers, carefully efface with their hands the traces of their timid footsteps. Thus man in the lowest stage of almost animal rudeness, as well as amidst the apparent brilliancy of our higher cultivation, prepares for himself and his fellow 
men increased toil and danger. The traveller wandering over the wide globe by sea and land, as well as the historic inquirer searching the records of past ages, finds every where the uniform and saddening spectacle of man at variance with man.

$\mathrm{He}$, therefore, who, amidst the unreconciled discord of nations, seeks for intellectual calm, gladly turns to contemplate the silent life of vegetation, and the hidden activities of forces and powers operating in the sanctuaries of nature; or, obedient to the inborn impulse which for thousands of years has glowed in the human breast, gazes upwards in meditative contemplation on those celestial orbs, which are ever pursuing in undisturbed harmony their ancient and unchanging course. 


\section{ANNOTATIONS AND ADDITIONS.}

\section{(1) p. 1.—“The Lake of Tacarigua."}

In proceeding through the interior of South Amernca from the Caraccas or Venezuela shore towards the boundary of Brazil, from the 10th degree of North latitude to the Equator, the traveller crosses first an elevated mountainchain running in an east and west direction, next vast treeless Steppes or Plains (los Llanos), which stretch from the foot of the above-named mountains (the coast chain of Caraccas) to the left bank of the Orinoco, and lastly the range which occasions the Cataracts of Atures and Maypure. This latter range of mountains, to which $I$ have given the name of the Sierra Parime, runs in an easterly direction from the Cataracts to Dutch and French Guiana. It is a mass of mountains divided into many parallel ridges, and is the site of the fabled Dorado. It is bordered on the south by the forest plain, through which the river of the Amazons and the Rio Negro have formed the channels in which their waters flow. Those who desire a fuller acquaintance with the geography of these regions will do well to consult and compare the great map of La Cruz-Olmedilla, bearing date 1775, (from which almost all the more recent maps of South America have been formed,) and the map of Columbia 
constructed by me from my own astronomical determinations of geographical positions, and published in 1825 .

The coast chain of Venezuela, geographically considered, is a part of the chain of the Andes of Peru. The chain of the Andes divides itself, at the great mountain junction at the sources of the Magdalena, south of Popayan, (between $1^{\circ} 55^{\prime}$ and $2^{\circ} 20^{\prime}$ latitude), into three chains, the easternmost of which terminates in the snow-covered mountains of Merida. These mountains sink down towards the Paramo de las Rosas into the hilly land of Quibor and Tocuyo, which connects the coast chain of Venezuela with the Cordilleras of Cundinamarca. The coast chain forms an unbroken rampart from Porto Cabello to the promontory of Paria. Its mean height hardly equals 750 toises or 4795 English feet; yet single summits, like the Silla de Caracas (also called Cerro de Avila), decked with the purple-flowering Befaria the American Rose of the Alps, rise 1350 toises or 8630 English feet above the level of the sea. The coast of Terra Firma bears traces of devastation. We recognise everywhere the action of the great current which, sweeping from east to west, formed by disruption the West Indian Islands, and hollowed out the Caribbean gulf. The projecting tongues of land of Araja and Chuparipari, and especially the coast of $\mathrm{Cu}$ mana and New Barcelona, offer a remarkable spectacle to the geologist. The precipitous Islands of Boracha, Caracas, and Chimanas, rise like towers from the sea, and bear witness to the terrible pressure of the waters against the mountain chain when it was broken by their irruption. Perhaps, like the Mediterranean, the Antillean gulf was once an inland 
sea, which became suddenly connected with the ocean. The islands of Cuba, Hayti, and Jamaica, still contain the remnants of the lofty mountains of mica slate which bounded this sea to the north. It is remarkable that where these three islands approach each other most nearly the highest summits are found; and we may conjecture that the highest part of this Antillean chain was situated between Cape Tiburon and Point Morant. The Copper Mountains (Montañas de Cobre) near Santiago de Cuba have not yet been measured, but their elevation is probably greater than that of the Blue Mountains of Jamaica, (1138 toises, 7277 English feet,) which somewhat exceeds the height of the St. Gothard Pass. My conjectures on the valley-form of the Atlantic Ocean, and on the ancient connection of the continents, were given more in detail in a memoir written in Cumana, entitled Fragment d'un Tableau Géologique de l'Amerique Meridionale (Journal de Physique, Messidor, An. IX.) It is worthy of remark, that Columbus himself, in his Official Reports, called attention to the connection between the direction of the equatorial current and the form of the coast line of the larger Antilles. (Examen critique de l'hist. de la Géographie, p. 104-108.)

The northern and most cultivated part of the province of Caraccas is a country of mountains. The coast chain is divided like the Swiss Alps into several subordinate chains enclosing longitudinal valleys. The most celebrated of these is the pleasant valley of Aragua, which produces a great quantity of indigo, sugar, cotton, and, what is most re- 
markable, European wheat. The southern margin of this valley adjoins the beautiful lake of Valencia, whose old Indian name is Tacarigua. The contrast between its opposite shores gives it a striking resemblance to the Lake of Geneva. It is true that the bare mountains of Guigue and Guiripa have less grandeur of character than the Savoy Alps; but, on the other hand, the opposite bank of the Tacarigua lake, which is thickly clothed with plantains, mimosas, and triplaris, far surpasses in picturesque beauty the vineyards of the Pays de Vaud. The lake is about thirty geographical miles in length, and is full of small islands, which, as the loss of water by evaporation exceeds the influx, are increasing in size. Within some years sandbanks have even become real islands, and have received the significant name of the "Newly Appeared," Las Aparecidas. On the island of Cura the remarkable species of Solanum is cultivated which has edible fruit, and which Wildenow has described in the Hortus Berolinensis (1816, Tab. xxvii.) The height of the Lake of Tacarigua above the sea is almost 1400 French feet, (according to my measurement exactly 230 toises, or 1470 English feet,) less than the mean height of the valley of Caraccas. The lake has several kinds of fish (see my Observations de Zoologie et d'Anatomie comparée, T. ii p. 179-181), and is one of the most pleasing natural scenes which $I$ know in any part of the globe. In bathing, Bonpland and myself were often alarmed by the appearance of the Bava, an undescribed crocodile-like lizard, three or four feet in length, of repulsive aspect, but harmless to men. We found in the lake a 
Typha (Cats-tail), identical with the European Typha angustifoiia; a singular fact, and important in reference to the geography of plants.

Two varieties of sugar-cane are cultivated near the lake, in the valleys of Aragua: the common sugar-cane of the West Indies, Caña criolla; and the cane recently introduced from the Pacific, Caña de Otaheiti. The verdure of the Tahitian cane is of a much lighter and more agreeable tint, and a field of it can readily be distinguished at a great distance from a field of the common cane. The sugar-cane of Tahiti was first described by Cook and George Forster, who appear, however, from the excellent memoir of the latter upon the edible plants of the islands of the Pacific, to have been but little acquainted with its valuable qualities. Bougainville brought it to the Isle of France, from whence it was conveyed to Cayenne, and since 1792 it has been taken to Martinique, Hayti, and several of the smaller West Indian Islands. It was carried with the bread-frut tree to Jamaica by the brave but unfortunate Captain Bligh, and was introduced from the Island of Trinidad to the neighbouring coast of Caraccas, where it became a more important acquisition than the bread-fruit, which is never likely to supersede a plant so valuable and affording so large an amount of sustenance as the plantain. The Tahitian sugar-cane is much richer in juice than the common cane, said to be originally a native of the east of Asia. On an equal surface of ground it yields a third more sugar than the caña criolla, which has a thinner stalk and smaller joints. As, moreover, the West India islands begin to suffer great want of fuel, (in Cuba 
the wood of the orange tree is used for sugar boiling, the thicker and more woody stalk of the Tahitian cane is an important advantage. If the introduction of this plant had not taken place almost at the same time as the commencement of the bloody negro war in St. Domingo, the prices of sugar in Europe would have risen still higher than they did, in consequence of the ruinous effects of those troubles on agriculture and trade. It was an important question, whether the cane of the Pacific, when removed from its. native soil, would gradually degenerate and become the same as the common cane. Experience hitherto has decided against any such degeneration. In Cuba a caballeria (nearly 33 English acres) planted with Tahitian sugar-cane produces 870 hundred weight of sugar. It is singular that this important production of the islands of the Pacific is only cultivated in those parts of the Spanish colonies which are farthest from the Pacific. The Peruvian coast is only twenty-five days' sail from Tahiti, and yet, at the period of my travels in Peru and Chili, the Tahitian cane was unknown there. The inhabitants of Easter Island, who suffer much from deficiency of fresh water, drink the juice of the sugarcane, and (avery remarkable physiological fact) also sea water. In the Society, Friendly, and Sandwich Islands, the light green, thick-stalked sugar-cane is always the one cultivated.

Besides the Caña de Otaheiti and the Caña Criolla, a reddish African variety, called Caña de Guinea, is cultivated in the West Indies: its juice is less in quantity than that of the common Asiatic cane, but is said to be better suited for making rum. 
In the province of Caraccas the dark shade of the cacao plantations contrasts beautifully with the light green of the Tahitian sugar cane. Few tropical trees have such thick foliage as the Theobroma cacao. It loves hot and humid valleys : great fertility of soil and insalubrity of atmosphere are inseparable from each other in South America as well as in Asia; and it has even been remarked that as increasing caltivation lessens the extent of the forests, and renders the soil and climate less humid, the cacao plantations become less flourishing. For these reasons these plantations are diminishing in number and extent in the province of Caraccas, and increasing rapidly in the more eastern provinces of New Barcelona and Cumana, and particularly in the moist woody district between Cariaco and the Golfo Triste.

(2) p. 2.- "Banks' is the name given by the natives to this phenomenon."

The Llanos of Caraccas are occupied by a great and widely extended formation of congjomerate of an early period. In descending from the vallies of Aragua, and crossing over the most southern ridge of the coast chain of Guigue and Villa de Cura towards Parapara, one finds successively, gneiss and mica slate;-a probably silurian formation of clay slate and black limestone;-serpentine and greenstone in detached spheroidal masses ; - and, lastly, close to the margin of the great plain, small hills of augitic amygdaloid and porphyritic slate. These hills between Parapara and Ortiz appear to me like volcanic eruptions on VOL. I. 
the ancient sea-shore of the Llanos. Farther to the north are the celebrated grotesque-shaped cavernous rocks of Morros de San Juan; they form a kind of rampart, have a crystalline grain like upheaved dolomite, and are rather to be regarded as parts of the shore of the ancient gulf than as islands. I term the Llanos a gulf, for when we consider their small elevation above the present sea level, their form. open as it were to the equatorial current sweeping from east to west, and the lowness of the eastern coast between the mouth of the Orinoco and the Essequibo, we can scarcely doubt that the sea once overflowed the whole basin between the coast chain of Caraccas and the Sierra de la Parime, and beat against the mountains of Merida and Pamplona; (as it is supposed to have overflowed the plains of Lombardy, and beat against the Cottian and Pennine Alps). The strike or inclination of the American Llanos is also durected from west to east. Their height at Calabozo, 400 geographical miles from the sea, is barely 30 toises (192 English feet); being 15 toises (96 English feet) less than that of Pavia, and 45 toises (288 English feet) less than that of Milan, in the plains of Lombardy between the Alps and Apennines. The form of the surface of this part of the globe reminds one of Claudian's expression, "curvata tumore parvo planities." The horizontality of the Llanos is so perfect that in many portions of them no part of an area of more than 480 square miles appears to be a foot higher than the rest. If, in addition to this, we imagine to ourselves the absence of all bushes, and even in the Mesa de Pavones the absence of any isolated palm-trees, it will afford some idea of the 
singular aspect of this sea-like desert plain. As far as the eye can reach, it can hardly rest on a single object a few inches high. If it were not that the state of the lowest strata of the atmosphere, and the consequent changes of refraction, render the horizon continually indeterminate and undulating, altitudes of the sun might be taken with the sextant from the margin of the plain as well as from the horizon at sea. This great horizontality of the former sea bottom makes the "banks" more striking. They are broken strata which rise abruptly from two to three feet above the surrounding rock, and extend uniformly over a length of from 4.0 to 4.8 English geographical miles. The small streams of the Steppes take their rise on these banks.

In passing through the Llanos of Barcelona, on our return. from the Rio Negro, we found frequent traces of earthquakes. Instead of the banks standing higher than the surrounding rock, we found here solitary strata of gypsum from 3 to 4 toises (19 to 25 English feet) lower. Farther to the west, near the junction of the Caura with the Orinoco, and to the east of the mission of S. Pedro de Alcantara, an extensive tract of dense forest sank down in an earthquake in 1790, and a lake was formed of more than 300 toises (1918 English feet) diameter. The tall trees (Desmanthus, Hymenæas, and Malpighias) long retained their foliage and verdure under the water.

${ }^{(3)}$ p. 2.- "We seem to see before us a shoreless ccean."

The prospect of the distant Steppe is still more striking, when the spectator has been long accustomed in the dense 
forests both to a very restricted field of view, and to the aspect of a rich and highly luxuriant vegetation. Ineffaceable is the impression which I received on our return from the Upper Orinoco, when, from the Hato del Capuchino, on a mountain opposite to the mouth of the Rio Apure, we first saw again the distant Steppe. The sun had just set; the Steppe appeared to rise like a hemisphere; and the light of the rising stars was refracted in the lowest stratum of air. The excessive heating of the plain by the vertical rays of the sun causes the variations of refraction,-occasioned by the effects of radiation, of the ascending current, and of the contact of strata of air of unequal density, - to continue through the entire night,

\section{(4) p. 2.- "The naked stony crust."}

Immense tracts of flat bare rock form peculiar and characteristic features in the Deserts both of Africa and Asia. In the Schamo, which separates Mongolia and the mountain chains of Ulangom and Malakha-Oola from the north-west part of China, these banks of rock are called Tsy. They are also found in the forest-covered plains of the Orinoco, surrounded by the most luxuriant vegetation (Relation Hist. t. ii. p. 279). In the middle of these flat tabular masses of granite and syenite of some thousand feet diameter, denuded of all vegetation save a few scantily distributed lichens, we find small islands of soil, covered with low and always flowering plants which give them the appearance of little gardens. The monks of the Upper Orinoco regard these bare and perfectly level surfaces of rock, when 
they are of considerable extent, as peculiarly apt to cause fevers and other illnesses. Several missionary villages have been deserted or removed elsewhere in consequence of this opinion, which is very widely diffused. Supposing the opinion correct, is such an influence of these flat rocks or laxas to be attributed to a chemical action on the atmosphere, or merely to the effect of increased radiation?

\section{(5) p. 2.- "The Llanos and Pampas of South America, and the Prairies of the Missouri."}

The physical and geognostical views entertained respecting the western part of North America have been rectified in many respects by the adventurous journey of Major Long, the excellent writings of his companion Edwin James, and more especially by the comprehensive observations of Captain Frémont. These, and all other tecent accounts, now place in a clear light what, in my work on New Spain, I could only put forward as conjecture, on the subject of the mountain ridges and plains to the north. In the description of nature as well as in historical inquiries, facts long remain isolated, until by laborious investigation they are brought into connection with each other.

The east coast of the United States of North Amierica runs from south-west to north-east, in the same direction as that followed in the southern hemisphere by the Brazilian coast from the river Plate to Olinda. In the two hemispheres two ranges of mountains exist at a short distance from the eastern coast; they are more nearly parallel to 
each other than they are to the more westerly chain, called in South America the Cordilleras of Peru and Chili, and in North America the Rocky Mountains. The Brazilian system of mountains forms an isolated group, of which the lighest summits (the Itacolumi and Itambe) do not rise above the height of 900 toises (5755 English feet). The most easterly ridges, which are nearest to the Atlantic, follow a uniform direction from SSW. to NNE.; more to the west the group becomes broader, but diminishes considerably in height. The Parecis hills approach the rivers Itenes and Guaporé, and the mountains of Aguapelii (to the south of Villabella) approach the lofty Andes of Cochabamba and Santa Cruz de la Sierra.

There is no immediate connection between the eastern and western chains, - the Brazilian mountains, and the Cordilleras of Peru,-for the low province of Chiquitos, which is a longitudinal valley running from north to south, and opening into the plains both of the Amazons and of the river Plate, separates Brazil on the east from the Alto Peru on the west. Here, as in Poland and Russia, an often almost imperceptible rise of ground (called, in Slavonian, Uwaly) forms the separating water-line between the Pilcomayo and the Madeira, between the Aguapehi and the Guaporé, and between the Paraguay and the Rio Topayos. The swell of the ground runs to the south-east from Chayanta and Pomabamba (lat. $19^{\circ}-20^{\circ}$ ), traverses the province of Chiquitos, which, since the expulsion of the Jesuits, has again become almost a terra incognita, and forms, to the north-east, where there are only detached mountains, the "divortia 
aquarum" at the sources of the Baures and near Villabella, lat. $15^{\circ}-17^{\circ}$.

This line of separation of the waters is important in relation to facilities of intercourse, and to the increase of cultivation and civilisation : more to the north $\left(2^{\circ}-3^{\circ} \mathrm{N}\right.$. lat.), a similar line divides the basin of the Orinoco from that of the Amazons and the Rio Negro. These risings or swellings in the plains (called, by Frontin, terræ tumores) might be regarded as undeveloped systems of mountains, which would have connected two apparently isolated groups (the Sierra Parime and the Brazilian mountains) with the Andes of Timana and Cochabamba. These relations, which have been hitherto but little attended to, are the ground of the division which I have made of South America into three basins; viz. those of the lower Orinoco, of the Amazons, and of the Rio de la Plata. The first and last of these are steppes or prairies; the middle basin, that of the Amazons, between the Sierra Parime and the Brazilian group of mountains, is a forestcovered plain or Hyloa.

If we wish to trace, in equally few lines, a sketch of the natural features of North America, let us cast our eyes first on the mountain chain which, running from south-east to north-west, at first low and narrow, and increasing both in breadth and height from Panama to Veragua, Guatimala, and Mexico (where it was the seat of a civilisation which preceded the arrival of Europeans), arrests the general equatorial current of the waters of the ocean, and opposes a barrier to the more rapid commercial intercourse of Europe and Western Africa with the eastern parts of Asia. North 
of the 17th degree of latitude and the celebrated isthmus of Tehuantepec, the mountains, quitting the coast of the Pacific, and following a more direct northerly course, become an inland Cordillera. In North Mexico, the "Crane Mountains" (Sierra de las Grullas) form part of the Rocky Mountain chain. Here rise, to the west, the Columbia and the Rio Colorado of California ; and, to the east, the Rio Roxo de Natchitoches, the Candian, the Arkansas, and the Platte or shallow river, a name which has latterly been ignorantly transformed into that of a silver-promising river Plate. Between the sources of these rivers (from N. lat. $37^{\circ} 20^{\prime}$ to $40^{\circ} 13^{\prime}$ ) rise three lofty summits (formed of a granite containing much hornblende and little mica), called Spanish Peak, James's or Pike's Peak, and Big Horn or Long's Peak. (See my Essai Politique sur la Nouvelle Espagne, 2me édit. t. i. pp. 82 and 109.) The elevation of these peaks exceeds that of any of the summits of the Andes of North Mexico, which, indeed, from the 18th and 19th parallels of latitude, or from the group of Orizaba and Popocatepetl (respectively 2717 toises or 17374 English feet, and 2771 toises or 17720 English feet,) to Santa Fé and Taos, never reach the limits of perpetual snow. James Peak, in lat. $38^{\circ} 40^{\prime}$, is supposed to be 1798 toises, or 11497 English feet; but of this elevation only 1335 toises (8537 English feet) has been measured trigonometrically, the remaining 463 toises, or 2960 English feet, being dependent, in the absence of barometrical observations, on uncertain estimations of the declivity of streams. As a trigonometrical measurement can hardly ever be undertaken 
from the level of the sea, measurements of inaccessible heights must generally be partly trigonometrical, and partly barometrical. Estimations of the fall of rivers, of their rapidity and of the length of their course, are so deceptive, that the plain at the foot of the Rocky Mountains, nearest to the summits above spoken of, was estimated, previous to the important expedition of Capt. Frémont, sometimes at 8000, and sometimes at 3000 feet. (Long's Expedition, vol. ii. pp. 36, 362, 382, App. p. xxxvii.) It was from a similar deficiency of barometrical measurements that the true elevation of the Himalaya continued so long uncertain : but now the resources which belong to the cultivation of science have increased in India to such a degree, that Captain Gerard, when on the Tarhigang, near the Sutlej, north of Shipke, at an elevation of 19411 English feet, after breaking three barometers, had still four equally correct ones remaining. (Critical Researches on Philology and Geography, 1824, p. 144.)

Frémont, in the expedition which he made in the years 1842 - 1844 by order of the Government of the United States, found the highest summit of the whole chain of the Rocky Mountains to the north north-west of Spanish, James's, Long's, and Laramie Peaks. This snowy summit, of which he measured the elevation barometrically, belongs to the group of the Wind River mountains. It bears on the large map, edited by Colonel Abert, Chief of the Topographical Office at Washington, the name of Frémont's Peak, and is situated in $43^{\circ} 10^{\prime}$ lat. and $110^{\circ} 13^{\prime} \mathrm{W}$. long. from Greenwich, almost $5 \frac{1^{\circ}}{2}$ north of Spanish Peak. Its height, 
by direct measurement, is 12730 French, or 13568 English feet. This would make Frémont's Peak 324 toises (or 2072 English feet) higher than the elevation assigned by Long to James's Peak, which, according to its position, appears to be identical with Pike's Peak in the map above referred to. The Wind River mountains form the divortia aquarum, or division between the waters flowing towards either ocean. Captain Frémont (in his Official Report of the Exploring Expedition to the Rocky Mountains in the year 1842, and to Oregon and North California in the years 1843-44, p. 70,) says, "We saw, on one side, countless mountain lakes, and the sources of the Rio Colorado which carries its waters through the gulf of California to the Pacific; and, on the other side, the deep valley of the Wind river, where are situated the sources of the Yellowstone river, one of the principal branches of the Missouri which unites with the Mississippi at St. Louis. To the northwest, rise, covered with perpetual snow, the summits called the Trois Tetons, where the true source of the Missouri itself is situated, not far from that of the head water of the Oregon or Columbia, or the source of that branch of it called Snake River or Lewis Fork." To the astonishment of the adventurous travellers, they found the top of Frémont's Peak visited by bees: perhaps, like the butterflies seen by me, also among perpetual snow but in much more elevated regions in the Andes of Peru, they had been carried thither involuntarily by ascending currents of air. I have seen in the Pacific, at a great distance from the coast, large winged lepidopterous insects fall on the deck of the ship, 
having, no doubt, been carried far out to sea by land winds.

Frémont's map and geographical investigations comprehend the extensive region from the junction of the Kanzas river with the Missouri, to the falls of the Columbia and to the missions of Santa Barbara and Pueblo de los Angeles in New California; or a space of 28 degrees of longitude, and from the 34th to the 45th parallel of latitude. Four hundred points have been determined hypsometrically by barometric observations, and, for the most part, geographically by astronomical observations; so that a district which, with the windings of the route, amounts to 3600 geographical miles, from the mouth of the Kanzas to Fort Vancouver and the shores of the Pacific (almost 720 miles more than the distance from Madrid to Tobolsk), has been represented in profile, shewing the relative heights above the level of the sea. As I was, I believe, the first person who undertook to represent, in geognostic profile, the form of entire countries,--such as the Iberian peninsula, the highlands of Mexico, and the cordilleras of South America, (the semiperspective projections of a Siberian traveller, the Abbé Chappe, were founded on mere and generally ill-judged estimations of the fall of rivers), -it has given me peculiar pleasure to see the graphical method of representing the form of the earth in a vertical direction, or the elevation of the solid portions of our planet above its watery covering, applied on so grand a scale as has been done in Frémont's map. In the middle latitudes of $37^{\circ}$ to $43^{\circ}$, the Rocky Mountains present, besides the higher snowy summits 
comparable with the Peak of Teneriffe in elevation, lofty plains of an extent hardly met with elsewhere on the surface of the earth, and almost twice as extensive in an east and west direction as that of the Mexican plateaux. From the group of mountains, which commences a little to the west of Fort Laramie to beyond the Wahsatch mountains, there is an uninterrupted swelling ' of the ground from 5300 to 7400 English feet above the level of the sea. A similar elevation may even be said to occupy the whole space from $34^{\circ}$ to $45^{\circ}$ between the Rocky Mountains proper and the Californian snowy coast chain. This space, a kind of broad longitudinal valley like that of the lake of Titiaca, has been called, by Joseph Walker, a traveller well acquainted with these western regions, and by Captain Frémont, "The Great Basin." It is a terra incognita of at least 128000 square miles in extent, arid, almost entirely without human inhabitants, and full of salt lakes, the largest of which is 4200 English feet above the level of the sea, and is connected with the narrow lake of Utah. (Frémont, Report of the Exploring Expedition, pp. 154 and 273-276.) The last-mentioned lake receives the abundant waters of the "Rock River;" Timpan Ogo, in the Utah language. Father Escalante, in journeying, in 1776, from Santa Fé del Nuevo Mexico to Monterey in New California, discovered Frémont's " Great Salt Lake," and, confounding lake and river, gave it the name of Laguna de Timpanogo. As such $I$ inserted it in my map of Mexico; and this has given rise to much uncritical discussion on the assumed non-existence of a great 
inland salt lake in North America,-a question previously raised by the well-informed American geographer, Tanner. (Humboldt, Atlas Mexicain, planche 2; Essai Politique sur la Nouvelle Espagne, T. i. p. 231, T. ii. pp. 243, 313, and 420 ; Frémont, Upper California, 1848, p. 9 ; and, also, Duflot de Mofras, Exploration de l'Oregon, 1844, T. ii. p. 40.) Gallatin says expressly, in the Memoir on the Aboriginal Races in the Archæologia Americana, vol. ii. p. 140, "General Ashley and Mr. J. S. Smith have found the lake Timpanogo in the same latitude and longitude nearly as had been assigned to it in Humboldt's Atlas of Mexico."

I have dwelt on the remarkable swelling of the ground in the region of the Rocky Mountains, because, doubtless, by its elevation and extent, it exercises an influence hitherto but little considered, on the climate of the whole continent of North America, to the south and east. In the extensive continuous plateau, Frémont saw the waters covered with ice every night in the month of August. Nor is the elevation of this region less important as respects the social state and progress of the great United States of North America. Although the elevation of the line of the separation of the waters nearly equals that of the passes of the Simplon (6170 French, or 6576 English feet), of the St. Gothard (6440 French, or 6865 English feet), and of the St. Bernard (7476 French, or 7969 English feet), yet the ascent is so gradual, as to offer no obstacle to the use of wheel carriages of all kinds in the communication between the basins of the Missouri and the Oregon; in other words, 
between the states on the Atlantic Sea Board opposite Europe, and the new settlements on the Oregon and Columbia opposite China. The itinerary distance from Boston to Astoria on the Pacific at the mouth of the Columbia, is, according to the difference of longitude, 2200 geographieal miles, or about one-sixth less than the distance of Lisbon from the Ural near Katharinenburg. From the gentleness of the ascent of the high plateau which leads from the Missouri to California and to the basin of the Oregon,-(from the River and Fort Laramie, on the northern branch of the Platte River, to Fort Hall on the Lewis Fork of the Columbia, all the camping places of which the height was measured were from upwards of five to seven thousand, and at Old Park even 9760 French, or 10,403 English feet);-it has not been easy to determine the situation of the culminating point, or "divortia aquarum." It is south of the Wind River mountains, nearly midway between the Mississipi and the coast of the Pacific, at an elevation of 7027 French, or 7490 English feet; therefore only 450 French, or 480 English, feet lower than the Pass of the great St. Bernard. The immigrants cali this point "the South Pass." (Frémont's Report, pp. 3, 60, 70, 100, 129). It is situated in a pleasant district, in which the mica slate and gneiss rock are found covered with many species of Artemisia, particularly Artemisia tridentata (Nuttall), asters, and cactuses. Astronomical determinations give the latitude $42^{\circ} 24^{\prime}$, and the longitude $109^{\circ} 24^{\prime}$ W. from Greenwich. Adolph Erman has already called attention to the circumstance that the 
direction of the great chain of the Aldan mountains in the east of Asia, which divides the streams flowing into the Lena from those which flow towards the Pacific, if prolonged on the surface of the globe in the direction of a great circle, passes through several summits of the Rocky Mountains, between the parallels of $40^{\circ}$ and $55^{\circ}$ “Thus an American and an Asiatic chain of mountains appear to belong to one great fissure, following the direction of a great circle, or the shortest course from point to point." (Compare Erman's Reise um die Erde, Abth. I. Bd. iii. S. 8, Abth. II. Bd. i. S. 386, with his Archiv für wissenschaftliche Kunde von Russland, Bd. vi. S. 671).

The Rocky Mountains which sink down towards the Mackenzie River which is covered a large portion of the year with ice, and the highlands from which single snow-clad summits rise, are altogether distinct from the more westerly and higher mountains of the coast, or the chain of the Californian Maritime Alps, the Sierra Nevada de California. However ill selected the now generally used name of the Rocky Mountains, to designate the most northerly continuation of the Mexican Central Chain, it does not appear to me desirable to change it, as has been often proposed, for that of the Oregon Chain. Although these mountains do indeed contain the sources of Lewis's, Clark's, and North Fork, the three chief branches which form the mighty Oregon, or Columbia River, yet this river also breaks through the Californian chain of snow-clad Maritime Alps. The name of Oregon District is also employed politically and officially for the smaller territory west of the 
Coast Chain, where Fort Vancouver and the Walahmutti settlements are situated, and therefore it is the more desirable not to give the name of Oregon either to the Central or the Coast Chain. This name is connected with a most singular mistake of an eminent geographer, M. Malte Brun: reading on an old Spanish map, "And it is not yet known, (y aun se ignora) where the source of this river" (the river now called the Columbia) "is situated," he thought he recognised in the word ignora the name of Oregon. (See my Essai politique sur 1a Nouvelle Espagne, T. ii. p. 314).

The rocks which, where the Columbia breaks through the Chain, form the Cataracts, mark the continuation of the Sierra Nevada de California from the 44th to the 47 th degree of latitude. (Frémont, Geographical Memoir upon Upper California, 1848, p. 6.) This northern continuation comprises the three colossal summits of Mount Jefferson, Mount Hood, and Mount St. Helen's, which rise more than 14540 French or 15500 English feet above the level of the sea. The height of this Coast Chain, or Range, far exceeds, therefore, that of the Rocky Mountains. "During a journey of eight months' duration which was made along the Maritime Alps," says Captain Frémont, in his Report, p. 274, "we had snowy peaks always in view; we had surmounted the Rocky Mountains by the South Pass at an elevation of 7027 (7490 E.) feet, but we found the passes of the Maritime Alps, which are divided into several parallel ranges, more than 2000 feet higher ;" therefore, only about 1170 feet $1247 \mathrm{E}$.) below the summit of Etna. It is extremely 
remarkable, and reminds us of the difference between the eastern and western cordilleras of Chili, that it is only the chain of mountains nearest to the sea (the Californian range), which has still active volcanoes. The conical mountains of Regnier and St. Helen's are seen to emit smoke almost constantly, and on the 23rd of November 1843, Mount St. Helen's sent forth a quantity of ashes which covered the banks of the Columbia for forty miles like snow. To the volcanic Coast Range also belong, (in Russian America in the high north), Mount St. Elias (1980 toises high, according to La Perouse, and 2792 toises, according to Malaspina (12660 and 17850 E. feet), and Mount Fair Weather, (Cerro de Buen Tempo) 2304 toises, or 14732 E. feet high. Both these mountains are supposed to be still active volcanoes. Frémont's expedition, (which was important alike for its botanical and geological results), collected volcanic products, such as scoriaceous basalt, trachyte, and even obsidian, in the Rocky Mountains, and found an extinct volcanic crater a little to the east of Fort Hall, (lat. $43^{\circ} 2^{\prime}$, long. $112^{\circ} 28$ W.); but there are no signs of volcanoes still active, that is to say, emitting at times lava or ashes. We are not to confound with such activity the still imperfectly explained phenomenon of "smoking hills ;" "côtes brûlées," or "terrains ardens," as they are called by the English settlers, and by natives speaking French. An accurate observer, M. Nicollet, savs, "ranges of low conical hills are covered with a thick black smoke almost periodically, and often for two or three years together. No flames are seen." This phenomenon

vOL. I. 
shews itself principally in the district of the Upper Missouri, and still nearer to the eastern declivity of the Rocky Mountains, where a river bears the native name of MankizitahWatpa, or the "river of the smoking earth." Scoriacous pseudo-volcanic products, such as a kind of porcelain jasper, are found in the vicinity of the "smoking hills." Since the expedition of Lewis and Clark an opinion has become prevalent that the Missouri deposits real pumice on its banks. Fine cellular whitish masses have been confounded with pumice. Professor Ducatel was disposed to ascribe this appearance, which was principally observed in the chalk formation, to a "decomposition of water by sulphuric pyrites, and to a reaction on beds of lignite." (Compare Frémont's Report, p. 164, 184, 187, 193, and 299, with Nicollet's 'Tllustration of the Hydrographical Basin of the Upper Mississipi River, 1843, p. 39-41.)

If, in concluding these few general considerations on the physical geography of North America, we once more turn our attention to the spaces which separate the two diverging coast chains from the central chain, we find, in striking contrast, on the one hand, the arid uninhabited plateau of above five or six thousand feet elevation, which in the west intervenes between the central chain and the Californian Maritime Alps which skirt the Pacific ; and on the eastern side of the Rocky Mountains, between them and the Alleghanies, (the highest summits of which, Mount Washington and Mount Marcy, are, according to Lyell, 6240 and 5066 French, or 6652 and 5400 English feet above the level of the sea,) the vast, well-watered, and fertile 
low plain or basin of the Mississipi, the greater part of which is from 400 to 600 French feet above the level of the sea, or about twice the elevation of the plains of Lombardy. The hypsometric conformation of this eastern region, $i . e$. the altitude of its several parts above the sea, has been elucidated by the valuable labours of the highly-talented French astronomer, Nicollet, of whom science has been deprived by a too early death. His large and excellent map of the Upper Mississipi, constructed in the years 1836-1840, is based on 240 astronomically determined latitudes, and 170 barometric measurements of elevation. The plain which contains the basin of the Mississipi is one with the Northern Canadian plain, so that one low region extends from the Gulf of Mexico to the Arctic Sea. (Compare my Rélation Historique T. iii. p. 234, and Nicollet's Report to the Senate of the United States, 1843, p. 7 and 57.) Where the plain is undulating, and where, between $47^{\circ}$ and $48^{\circ}$ of latitude, low hills (côteaux des prairies, and côteaux des bois, in the still un-English nomenclature of the natives) occur in connected ranges, these ranges and gentle swellings of the ground divide the waters which flow towards Hudson's Bay from those which seek the Gulf of Mexico. Such a dividing line is formed north of Lake Superior by the Missabay Heights, and more to the west by the "Hauteurs des Terres," in which were first discovered, in 1832, the true sources of the Mississipi, one of the largest rivers in the world. The highest of these ranges of hills hardly attains an elevation of 1400 to 1500 -(1492 to 1599 English) feet. From St. Louis, a little to the south of the junction of the Mis- 
suuri and the Mississipi, to the mouth of the latter river at Old French Balize, it has only a fall of 357 (380 English) feet in an itinerary distance of more than 1280 geographical miles The surface of Lake Superior is 580 (618 English) feet above the level of the sea, and its depth near Magdalen Island is 742 (791 English) feet; its bottom, therefore, is 162 (173 English) feet below the surface of the ocean. (Nicollet, p. 99, 125, and 128.)

Beltrami, who separated himself from Major Long's expedition in 1825, boasted of having discovered the source of the Mississipi in Lake Cass. The river in the upper part of its course passes through four lakes, of which Lake Cass is the second. The uppermost is the Istaca Lake (in lat. $47^{\circ}$ $13^{\prime}$ and long. $95^{\circ} 0^{\prime}$ ), and was first recognised as the true source of the Mississipi in the expedition of Schoolcraft and Allen in 1832. This afterwards mighty river is only 17 feet wide and 15 inches deep when it issues from the singular horse-shoe-shaped Lake of Istaca. Itwas not until the scientific expedition of Nicollet, in 1836, that a clear knowledge of the localities was obtained and rendered definite by astronomically determined positions. The height of the sources of the Mississipi, viz. of the remotest affluent received by the Lake of Istaca from the dividing ridge or "Hauteur de Terre," is 1575 (1680 English) feet above the level of the sea. In the immediate vicinity, and indeed on the southern slope of the same dividing ridge, is Elbow Lake, in which the smaller Red River of the North, which after many windings flows into Hudson's Bay, has its origin. The Carpathian mountains present similar circumstances in the 
proximity and relative positions of the sources of rivers which send their waters respectively to the Black Sea and to the Baltic. Twenty small lakes, forming narrow groups to the south and west of Lake Istaca, have received from M. Nicollet the names of distinguished European astronomers, adversaries as well as friends. The map thus becomes a kind of geographical album, reminding one of the botanical album of Ruiz and Pavon's Flora Peruviana, in which the names of new genera of plants were adapted to the Court Calendar, and to the various changes taking place in the Oficiales de la Secretaria.

To the east of the Mississipi dense forests still partially prevail ; but to the west of the river there are only Prairies, in which the buffalo (Bos americanus), and the musk ox (Bos moschatus), feed in large herds. Both these animals, (the largest of the New World) serve the wandering Indians, the Apaches Llaneros and the Apaches Lipanos, for food. The Assiniboins sometimes kill in a few days from seven to eight hundred bisons in what are called "bison parks," artificial enclosures into which the wild herds are driven. (Maximilian, Prinz zu Wied, Reise in das innere Nord-America, Bd. i. 1839, S. 443.) The American bison, or buffalo, called by the Mexicans Cibolo, which is frequently killed merely for the sake of the tongue a much-prized dainty, is by no means a mere variety of the Aurochs of the Old Continent; although some other kinds of animals, as the elk (Cervus alces) and the reindeer (Cervus tarandus), and even, in the human race, the short-statured polar man, are common to the northern parts of both continents, evidencing 
their former long continued connection. The Mexicans call the European ox in the Aztec dialect "quaquahue," a horned animal, from quaquahuitl, a horn. Some very large horns of cattle found in the ancient Mexican buildings not far from Cuernavaca, to the south-west of the city of Mexico, appear to me to have belonged to the musk ox. The Canadian bison can be tamed to agricultural labour. It breeds with the European cattle, but it was long uncertain whether the hybrid was fruitful. Albert Gallatin, who, before he appeared in Europe as a distinguished diplomatist, had obtained by personal inspection great knowledge of the uncultivated parts of the United States, assures us that " the mixed breed was quite common fifty years ago in some of the north-western counties of Virginia; and the cows, the issue of that mixture, propagated like all others." "I do not remember," he adds, "the grown bison being tamed, but sometimes young bison calves were caught by dogs, and were brought up and driven out with the European cows." At Monongahela all the cattle were for a long time of this mixed breed : but complaints were made that they gave very little milk. The favourite food of the bison or buffalo is Tripsacum dactyloides (called buffalo grass in North Carolina), and an undescribed species of clover nearly allied to Trifolium repens, and designated by Barton as Trifolium bisonicum.

I have already called attention elsewhere (Cosmos, vol. ii. note 455, English ed.) to the circumstance that, according to a statement of the trustworthy Gomara, (Historia General de las Indias, cap. 214) there was still living in the six- 
teenth century, in the north-west of Mexico, in $40^{\circ}$ latitude, an Indian tribe, whose principal riches consisted in herds of tame bisons (bueyes con una giba). But notwithstanding the possibility of taming the bison, notwithstanding the quantity of milk it yields, and notwithstanding the herds of lamas in the Cordilleras of Peru, no pastoral life or pastoral people were found when America was discovered, and there is no historical evidence of this intermediate stage in the life of nations ever having existed there. It is worthy of remark that the American buffalo or bison has exerted an influence on the progress of geography in trackless mountainous regions. These animals wander in the winter, in search of a milder climate, in herds of several thousands to the south of the Arkansas River. In these migrations their size and unwieldiness make it difficult for them to pass over high mountains. When, therefore, a well-trodden buffalo path is met with, it is advisable to follow it, as being sure to conduct to the most convenient pass across the mountains. The best routes through the Cumberland Mountains, in the south-west parts of Virginia and Kentucky, in the Rocky Mountains between the sources of the Yellow Stone and the Platte, and between the southern branch of the Columbia and the Rio Colorado of California, were thus marked out beforehand by buffalo paths. The advance of settlement and cultivation has gradually driven the buffalo from all the Eastern states: they formerly roamed on the banks of the Mississipi and of the Ohio far beyond Pittsburg. (Archæologia Americana, vol. ii., 1836, p. 139.) 
From the granitic cliffs of Diego Ramirez,-in the deeply indented and intersected Tierra del Fuego, which contains on the east silurian schists and on the west the same schists altered by the metamorphic action of subterranean fire, (Darwin's Journal of Researches into the Geology and Natural History of the Countries visited in 1832-1836 by the Ships Adventure and Beagle, p. 266),- - to the North Polar Sea, the Cordilleras extend in length more than 8000 geographical miles. They are the longest though not the loftiest chain on our planet ; being raised from a cleft running in the direction of a meridian from pole to pole, and exceeding in linear distance the interval which in the Old Continent separates the Pillars of Hercules from the Tcy Cape of the Tchuktches in the north-east of Asia. Where the Andes divide into several parallel chains, it is remarked that the ranges nearest the sea are usually those which exhibit most volcanic activity; but it has also been observed repeatedly, that when the phenomena of still active subterranean fire disappear in one chain, they break out in another chain running parallel to it. Generally speaking, the volcanic cones are found in a direction corresponding with that of the axis of direction of the entire chain; but in the elevated highlands of Mexico the active volcanoes are placed along a transverse cleft running from sea to sea in the east and west direction. (Humboldt, Essai Politique, T. ii. p. 173.) Where, by the elevation of mountain masses in the ancient corrugation or folding of the crust of the earth, access has been opened to the molten interior, that interior continues to act, through the medium of the cleft, 
upon the upheaved wall-like mass. That whicn we now call a mountain chain has not arrived at once at its present state: rocks, very different in the order of succession in reference to age, are found superimposed upon each other, and have penetrated to the surface by early formed channels. The various nature of the formations is due to the outponring and elevation of eruptive rocks, as well as to the slow and complicated process of metamorphic action taking place in clefts filled with vapours and favourable to the conduction of heat..

For a long time past, from 1830 to 1848 , the following have been regarded as the culminating or highest points of the Cordilleras of the New Continent.

The Nevado de Sorata, also called Ancohuma or Tusubaya, (S. lat. $15^{\circ} 52^{\prime}$ ) a little to the south of the village of Sorata or Esquibel, in the eastern Bolivia Range: elevation 3949 toises, or 23692 Parisian, or 25250 English feet.

The Nevado de Illimani, west of the Mission of Yrupana (S. lat. $16^{\circ} 38^{\prime}$ ) in the same mountain range as Sorata : elevation 3753 toises, or 22518 Parisian, or 24000 English feet.

The Chimborazo (S. lat. $1^{\circ} 27^{\prime}$ ) in the province of Quito: elevation 3350 toises, or 20100 Parisian, or 21423 English feet.

The Sorata and Illimani were first measured by a distinguished geologist, Mr. Pentland, in 1827, and also in 1838. Since the publication, in June 1848, of his great map of the basin of the lake of Titizaca, we know that the above-mentioned elevations of these two mountains are 
respectively 3960 and 2851 English feet, too great. The map gives to the Sorata 21286, and to the Illimani 21149 English feet. A more exact calculation of the trigonometrical operations of 1838 has led Mr. Pentland to these new results. There are, according to him, in the western Cordillera four peaks of from 21700 to 22350 English feet. The highest of these, the peak of Sahama, would thus be 926 English feet higher than the Chimborazo, and but 850 English feet lower than the Volcano of Acongagua, measured by the expedition of the Beagle (Fitz Roy's Narrative, Vol. ii. p. 481.)

\section{(6) p. 3.- "The Desert near the basaltic mountains of Harudsh."}

Near the Egyptian Natron Lakes, (which in the time of Strabo had not yet been divided into six reservoirs), there is a range of hills which rises steeply on the northern side, and runs from east to west past Fezzan, where it finally appears to join the chain of the Atlas. It divides in north-eastern Africa, as the Atlas does in north-western Africa, the inhabited maritime Lybia of Herodotus from the land of the Berbers, or Biledulgerid, abounding in wild animals. From the limits of Middle Egypt the whole region south of the 30th degree of North latitude is a sea of sand, in which are dispersed islands, or Oases, containing springs of water and a flourishing vegetation. The number of these Oases, of which the ancients only reckoned three, and which Strabo compared to the spots on a panther's skin, has been considerably augmented by the discoveries of modern travellers. The third Oasis of the ancients, now called 
Siwah, was the Nomos of Ammon; a residence of priests, a resting place for caravans, and the site of the temple of the horned Ammon and the supposed periodically cool fountain of the Sun. The ruins of Ummibida, (OmmBeydah), belong incontestibly to the fortified caravanserai at the temple of Ammon, and therefore to the most ancient monuments which have come down to us from the early dawn of civilization. (Caillaud, Voyage à Syouah, p. 14; Ideler in den Fundgruben des Orients, Bd. iv. S. 399411).

The word Oasis is Egyptian, and synonymous with Auasis and Hyasis (Strabo, lib. ii. p. 130, lib. xvii. p. 813, Cas.; Herod. lib. iii. cap. 26, p. 207, Wessel). Abulfeda calls the Oases, el-Wah. In the later times of the Cresars, malefactors were sent to the Uases; being banished to these islands in the sea of sand, as the Spaniards and the English have sent criminals to the Falklands or to New Holland. Escape by the ocean is almost easier than through the desert. The fertility of the Oases is subject to diminution by the invasion of sand.

The small mountain-range of Harudsh is said to consist of basaltic hills of grotesque form (Ritter's Afrika, 1822, S. $885,988,993$, and 1003). It is the Mons Ater of Pliny; and its western extremity or continuation, called the Soudah mountains, has been explored by my unfortunate friend, the adventurous traveller Ritchie. This eruption of basalt in tertiary limestone, rows of hills rising abruptly from dike-like fissures, appears to be analogous to the outbreak of basalt in the Vicentine territory. Nature often repeats the same phenomena in the most distant 
parts' of the earth. In the limestone formations of the "white Harudsh" (Harudje el-Abiad), which perhaps belong to the old chalk, Hornemann found an immense number of fossil heads of fish. Ritchie and Lyon remarked that the basalt of the Soudah mountains, like that of the Monte Berico, was in many places intimately mixed with carbonate of lime, - - a phenomenon probably connected with eruption through limestone strata. Lyon's map even mentions dolomite in the neighbourhood. Modern mineralogists have found syenite and greenstone in Egypt, but not basalt. Possibly the material of some of the ancient Egyptian vases, which are occasionally found of true basalt, may have been taken from these western mountains. May "Obsidius lapis" also have been found there? or are basalt and obsidian to be sought for near the Red Sea? The strip of volcanic or eruptive formations of the Harudsh, on the margin of the African desert, reminds the geologist of the augitic vesicular amygdaloid, phonolite, and greenstone porpyhry, which are only found at the northern and western boundaries of the Steppes of Venezuela and of the plains of the Arkansas, as it were on the hills of the ancient coast line. (Humboldt, Relation Historique, tom. ii. p. 142 ; Long's Expedition to the Rocky Mountains, vol. ii. pp. 91 and 405.)

\section{(7) p. 3.- When suddenly deserted by the east wind of the tropics in a sea covered with weed."}

It is a remarkable phenomenon, well known among sailors, that in the vicinity of the African coast (between the Canaries and the Cape de Verde Islands, and particularly between Cape Bojador and the mouth of the Senegal), 
a west wind often takes the place of the general east or trade-wind of the tropics. It is the wide expanse of the desert of Sahara which causes this westerly wind. The air over the heated sandy plain becomes rarefied and ascends, the air from the sea rushes in to supply the void so formed, and thus there sometimes arises a west wind, adverse to ships bound to the American coast, which are made in this manner to feel the vicinity of the heat-radiating desert without even seeing, the continent to which it belongs. The changes of land and sea breezes, which blow alternately at certain hours of the day or night on all coasts, are due to the same causes.

The accumulation of sea-weed in the neighbourhood of . the African coast has been often spoken of by ancient writers. The locality of this accumulation is a problem which is intimately connected with our conjectures respecting the extent of Phonician navigation. The Periplus, which has been ascribed to Scylax of Caryanda, and which, according to the researches of Niebuhr and Letronne, was very probably compiled in the time of Philip of Macedon, describes beyond Cerne a quantity of fucus forming a weedcovered sea-a kind of "Mar de Sargasso ;" but the locality indicated appears to me to differ very much from that assigned in the work entitled "De Mirabilibus Auscultationibus," which long bore, unduly, the great name of Aristotle. (Compare Scyl. Caryand. Peripl. in Hudson, vol. ii. p. 53, with Aristot. de Mirab. Auscult. in opp. omnia ex. rec. Bekkeri, p. 844, § 136.) The pseudo-Aristotle says, "Phœnician mariners, driven by the east wind, came in four days' sail from Gades to a nart where they found the sea 


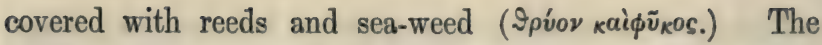
sea-weed is uncovered at ebb and covered at flood tide." Is he not here speaking of a shallow place between the $34^{\circ}$ and $36^{\circ}$ of latitude? Has a shoal dissappeared in consequence of volcanic eruption? Vobonne speaks of rocks north of Madeira. (Compare also Edrisi, Geog. Nub., 1619, p. 157.) In Scylax it is said, "The sea beyond Cerne is unnavigable on account of its great shallowness, its muddiness, and the great quantity of sea grasses. The sea grass lies a span thick, and is full of points at the top, so that it pricks." The sea-weed found between Cerne,(the Phœnician station for laden vessels, Gaulea, or, according to Gosselin, the small island of Fedallah, on the northwestern coast of Mauritania), - and Cape de Verde, does not now by any means form a great sea meadow, or connected tract of fucus, a "mare herbidum," such as exists beyond the Azores. In the poetic description of the coast by Festus Avienus, (Ora Maritima, v. 109, 122, 388, and 408), in the composition of which, as Avienus himself says, (v. 412) he availed himself of the journals of Phœnician ships, the obstacle presented by the sea-weed is referred to in a very circumstantial manner; but its site is placed much farther north, towards Ierne, the " Sacred Island."

Sic nulla late flabra propellunt ratem,

Sic segnis humor æquoris pigri stupet.

Adjicit et illud, plurimum inter gurgites

Exstare fucum, et sæpe virgulti vice

Retinere puppim . . .

Hæc inter undas multa cæspitem jacet,

Eamque late gens Hibernorum colit. 
In remarking that the fucus and the mud or mire, ( $\pi \eta \lambda$ ós), the shallowness of the sea, and the perpetual calms, are always spoken of by the ancients as characteristics of the western ocean beyond the Pillars of Hercules, one is disposed, more particularly on account of the mention of the calms, to ascribe something to Punic artifice,-to the desire of a great trading people to deter others, by the apprehension of dangers and difficulties, from entering into competition with them in western navigation and commerce. But even in the genuine writings of Aristotle (Meteorol. ii. p. 1,14 , ) he maintains this same opinion of the absence of wind in those regions, and seeks the explanation of what he erroneously supposes to be a fact of observation, but which is more properly a fabulous mariner's tale, in an hypothesis concerning the depth of the sea. In reality, the stormy sea between Gades and the islands of the Blest or Fortunate Islands, (between Cadix and the Canaries), is very unlike the sea farther to the south between the tropics, where the gentle trade winds blow, and which is called very characteristically by the Spaniards, el Golfo de las Damas, the Ladies' Gulf. (Acosta Historia natural y moral de las Indias, lib. iii. cap. 4.)

From very careful researches by myself, and. from the comparison of the logs or journals of many English and French vessels, I infer that the old and indefinite expression, Mar de Sargasso, includes two banks of fucus, of which the greater and easternmost one, of a lengthened shape, is situated between the parallels of $19^{\circ}$ and $34^{\circ} \mathrm{N}$. lat., in a meridian of 7 degrees to the west of the Island of 
Corvo, one of the Azores; while the lesser and westernmost bank, of a roundish form, is situated between the Bermudas and the Bahamas, (lat. $25^{\circ}-31^{\circ}$, long. $66^{\circ}-74^{\circ}$.) The longer axis of the small bank which is crossed by ships going from Baxo de Plata (Caye d'Argent, Silver Cay) on the north of St. Domingo, to the Bermudas, appears to have a N. $60^{\circ}$ E. direction. A transverse band of Fucus natans, running in an East and West direction between the parallels of $25^{\circ}$ and $30^{\circ}$, connects the greater and lesser banks. I have had the gratification of seeing these inferences approved by my honoured friend Major Rennell, and adopted by him in his great work on Currents, where he has further supported and confirmed them by many new and additional observations. (Compare Humboldt, Relation Historique, tom. i. p. 202, and Examen critique, tom. iii. p. 68-99, with Rennell's Investigation of the Currents of the Atlantic Ocean, 1832, p. 184.) The two groups of sea-weed, included together with the transverse connecting band under the old general name of the Sargasso Sea, occupy altogether a space exceeding six or seven times the area of Germany.

Thus it is the vegetation of the ocean which offers the most remarkable example of an assemblage of "social plants" of a single species. On terra firma, the savannahs or prairies, or grassy plains of America, the heaths (ericeta), and the forests of the North of Europe and Asia, consisting of coniferous trees, birches, and willows, offer a less degree of uniformity than do those thalassophytes. Our heaths show, in the north, in addition to the prevailing Calluna 
vulgaris, Erica tetralix, E. ciliaris, and E. cinerea; and in the south, Erica arborea, E. scoparia, and E. meditterranea. The uniformity of the aspect offered by the Fucus natans is greater than that of any other assemblage or association of plants. Oviedo calls the fucus banks "meadows," praderias de yerva. Considering that the island of Flores was discovered in 1452, by Pedro Velasco, a native of the Spanish port of Palos, by following the flight of certain birds from the island of Fayal, it seems almost impossible, seeing the proximity of the great fucus bank of Corvo and Flores, that a part of these oceanic meadows should not have been seen before Columbus, by Portuguese ships diven by storms to the westward. Yet the astonishment of the companions of Columbus in 1492, when surrounded by sea-weed uninterruptedly from the 16th of September to the 8th of October, shews that the magnitude of the phenomenon at least was previously unknown to the sailors. The anxieties excited by the accumulation of sea-weed, and the murmurs of his companions in reference thereto, are not indeed mentioned by Columbus in the extracts from the ship's journal given by Las Casas. He merely speaks of the complaints and murmurs respecting the danger to be feared from the weak but constant East winds. It is only the son, Fernando Colon, who, in writing his father's life, endeavoured to depict the fears of the sailors in a dramatic manner.

According to my researches, Columbus crossed the great fucus bank in 1492 , in lat. $28 \frac{1}{2}^{\circ}$, and in 1493 , in lat. $37^{\circ}$, both times in the long. of from $38^{\circ}$ to $47^{\circ} \mathrm{W}$. This is VOL. I. 
deducible with tolerable certainty from Columbus's recorded estimation of the ship's rate, and the " distance daily sailed over ;" derived indeed, not from casting the log, but from data afforded by the running out of half-hour sandglasses (ampolletas). The first certain and definite mention of a log (catena della poppa) which I have been able to discover, is in the year 1521, in Pigafetta's journal of Magellan's Voyage round the World. (Cosmos, vol. ii. p. 259, and Note 405, English ed.) The determination of the ship's place, while Columbus was engaged in traversing the great meadows of sea-weed, is the more important, because we learn from it that for three centuries and a half the situation of this great accumulation of thalassophytes, whether resulting from the local character of the bottom of the sea, or from the direction of the Gulf stream, has remained the same. Such evidences of the permanency of great natural phenomena arrest the attention of the physical inquirer with double force, when they present themselves in the evermoving oceanic element. Although the limits of the fucus banks oscillate considerably, in correspondence with the variations of the strength and direction of the prevailing winds, yet we may still in the middle of the 19th century take the meridian of $41^{\circ} \mathrm{W}$. from Paris $\left(38^{\circ} 38^{\prime} \mathrm{W}\right.$. from Greenwich) as the principal axis of the "great bank." In the vivid imagination of Columbus, the idea of the position of this bank was intimately connected with the great physical line of demarcation, which, according to him, divided the globe into two parts, with the changes of magnetic variation, and with climatic relations. Columbus, 
when uncertain respecting his longitude, (February 1493), directed himself by the appearance of the first floating streamers of weed (de la primera yerva) on the eastern margin of the great Corvo bank. The physical line of demarcation was, by the powerful influence of the Admiral, converted on the 4th of May, 1493, into a political line, being made the celebrated "line of demarcation" between the Spanish and Portuguese rights of possession. (Compare my Examen Critique, tom. iii. p. 64-99, and Cosmos, English ed. vol. ii. p. 279-280.)

(8) p. 3.- "The Nomadic Tibbos and Tuaricks."

These two nations inhabit the deserts between Bornou, Fezzan, and Lower Egypt. They were first made known to us with some exactness by Hornemann's and Lyon's travels. The Tibbos or Tibbous roam through the eastern, and the Tuaticks (Tueregs) through the western, parts of the great desert. The first are called by the other tribes, from being in continual movement, " birds." The Tuaricks are distinguished into those of Aghadez and those of Tagazi. They are often engaged as conductors of caravans, and in trade. Their language is the same as that of the Berbers; and they belong unquestionably to the number of the primitive Lybian nations. The Tuaricks present a remarkable physiological phenomenon. Different tribes among them are, according to the climate, white, yellowish, and even almost black; but all are without woolly hair or Negro features. (Exploration scientifique de l'Algérie, T. i. p. 343.) 


\section{(9) p. 4.— "The Ship of the Desert."}

In oriental poems, the camel is called the land-ship, or the ship of the Desert (Sefynet-el-badyet); Chardin, Voyages, nouv. éd. par Langlès, 1811, T. iii. p. 376.

But the camel is not merely the carrier of the desert, and the link which, rendering communication between different countries possible, connects them with each other: he is also, as Carl Ritter has shewn in his excellent memoir on the sphere of diffusion of these animals, the principal and essential condition of the nomadic life of nations in the patriarchal stage of national development, in the hot parts of our planet where rain is either altogether wanting or very infrequent. No animal's life is so closely associated by natural bonds with a particular stage of the developement of the life of man,-a connection historically established for several thousand years, - as the life of the camel among the Bedouin tribes" (Asien, Bd. viii. Abth. i. 1847, S. 610 und 758). "The camel was entirely unknown to the cultivated Carthaginian nation through all the centuries of their flourishing existence, until the destruction of their city. The Marusians first brought it into military use, in the train of armies, in Western Lybia, in the times of the Cæsars; perhaps in consequence of its employment in commercial operations in the valley of the Nile by the Ptolemies. The Guanches, the inhabitants of the Canary Islands and probably related to the Berber race, were not acquainted with the camel before the 15th century, 
when it was introduced by Norman conquerors and settlers. In the probably very limited communication of the Guanches with the Coast of Africa, the small size of the boats would prevent the transport of large animals. The true Berber race, diffused throughout the interior of Northern Africa, and to which the.Tibbos and Tuaricks, as already mentioned, belong, owes doubtless to the use of the camel throughout the Lybian desert and its Oases, not only the advantages of intercommunication, but also the preservation of its national existence to the present day. On the other hand, the negro races never, of their own accord, made any use of the camel; it was only in company with the conquering expeditions and proselyting missions of the Bedouins, carrying their prophet's doctrines over the whole of Northern Africa, that the useful animal of the Nedjid, of the Nabatheans, and of all the countries inhabited by Aramean races, spread to the westward and was introduced among the black popu lation. The Goths took camels as early as the fourth century to the Lower Istros (the Danube), and the Ghaznevides conveyed them in much larger numbers as far as India and the banks of the Ganges." We must distinguish two epochs in the diffusion of the camel throughout the northern part of the African continent; one under the Ptolemies, operating through Cyrene on the whole of the north-west of Africa; and the Mohammedan epoch of the conquering Arabs.

It has long been a question, whether those domestic animals which have been the earliest companions of mankindoxen, sheep, dogs, and camels-are still to be met wich in a 
state of original wildness. The Hiongnu, in Eastern Asia, belong to the nations who earliest tamed and trained wild camels as domestic animals. The compiler of the great Chinese work, Si-yu-wen-kien-lo, (Historia Regionum occidentalium, quæ Si-yu vocantur, visu et auditu cognitarum,) affirms that in the middle of the 18th century wild camels, as well as wild horses and wild asses, still wandered in East Turkestan. Hadji Chalfa, in his Turkish Geography, written in the 17th century, speaks of the frequent chase of the wild camel in the high plains of Kashgar, Turfan, and Khotan. Schott translates, from a Chinese author, Ma-dschi, that wild camels are to be found in the countries to the north of China and west of the Hoang-ho, in Ho-si or Tangut. Cuvier alone (Règne Animal, T. i. p. 257), doubts the present existence of wild camels in the interior of Asia. He believes they have merely "become wild;" because Calmucks, and others having Buddhistic religious affinities with them, set camels and other animals at liberty, in order " to acquire to themselves merit for the other world." According to Greek witnesses of the times of Artemidorus and Agatharchides of Cnidus, the Ailanitic Gulf of the Nabatheans was the home of the wild Arabian camel. (Ritter's Asien, Bd. viii. s. 670, 672, and 746.) The discovery of fossil camel bones of the ancient world by Captain Cautley and Doctor Falconer, in 1834, in the subHimalaya range of the Sewalik hills, is peculiarly deserving of notice. These bones were found with other ancient bones of mastodons, of true elephants, of giraffes, and of a gigantic land tortoise (Colossochelys), twelve feet in length 
and six feet in height. (Humboldt, Cosmos, Engl. ed. vol. i. p. 268.) This camel of the Ancient World has received the name of Camelus sivalensis, but does not show any considerable difference from the still living Egyptian and Bactrian camels with one and two humps. Forty camels have very recently been introduced into Java, having been brought there from Teneriffe. (Singapore Journal of the Indian Archipelago, 1847, p. 206.) The first experiment has been made in Samarang. In like manner, reindeer have only been introduced into Iceland from Norway in the course of the last century. They were not found there when the island was settled, notwithstanding the proximity to East Greenland, and the existence of floating masses of ice. (Sartorius von Waltershausen physisch-geographische Skizze von Island, 1847, S. 41.)

\section{(10) p. 4.)—“Between the Altai and the Kuen-liin."}

The great highland, or, as it is commonly called, the mountain plateau of Asia, which includes the lesser Bucharia, Songarei, Thibet, Tangut, and the Mogul country of the Chalcas and Olotes, is situated between the 36th and 48th degrees of latitude, and the meridians of $81^{\circ}$ and $118^{\circ} \mathrm{E}$. long. It is an erroneous view to represent this part of the interior of Asia as a single undivided mountainous gibbosity, continuous like the elevated plains of Quito and Mexico, and elevated from seven to nine thousand feet above the level of the sea. That there is not in this sense any undivided mountain plateau in the interior of Asia, has already been shewn by me in my "Researches respecting the Mountains of Northern India." 
(Humboldt, Premier Mémoire sur les Montagnes de l'Tnde, in the Annales de Chimie et de Physique, T. iii. 1816, p. 303 ; Second Mémoire, T. xiv. 1820, p. 5-55.)

My views concerning the geographical range of plants, and the mean degree of temperature requisite for certain kinds of cultivation, had early led me to entertain considerable doubts as to the continuity of a great Tartarian plateau between the Himalaya and the Altai. Writers continued to characterise this plateau as it had been described by Hippocrates (De Are et Aquis, $\S$ xcvi. p. 74), as " the high and naked plains of Scythia, which, without being crowned with mountains, rise and extend to beneath the constellation of the Bear." Klaproth has the undeniable merit of having been the first to make us acquainted with the true position, extent, and direction of two great and entirely distinct chains of mountains-the Kuen-liun and the Thianschan, in a part of Asia which is better entitled to the name of "central" than Kashmeer, Baltistan, and the Sacred Lakes of Thibet, (the Manasa and the Ravanahrada). The importance of the Celestial Mountains, the Thian-schan, had indeed been already surmised by Pallas, without his being aware of their volcanic nature; but this highly-gifted investigator of nature, hampered by the then prevailing hypothesis of a dogmatic and fantastic geology, firmly believing in " chains of mountains radiating from a centre," saw in the Bogdo Oola (the Mons Augustus, or culminating point of the Thian-schan) such a "central node, from whence all the Asiatic mountain chains diverge in rays, and which dominates over all the rest of the continent !" 
The erroneous idea of a single vast elevated plain occupying the whole of central Asia, the "Plateau de la Tartarie," took its rise in France, in the latter half of the 18th century. It was the result of historical combinations, and of a not sufficiently attentive study of the writings of the celebrated Venetian traveller, as well as of the naïve relations of those diplomatic monks who, in the 13th and 14th centuries, (thanks to the unity and extent of the Mogul empire at that time) were able to traverse almost the whole of the interior of the continent, from the ports of Syria and of the Caspian Sea to the shores of the Pacific on the east coast of China. If a more exact acquaintance with the language and ancient literature of India had dated farther back among us than half a century, the hypothesis of this central plateau, occupying the wide space between the Himalaya and the south of Siberia, would no doubt have had adduced in its support an ancient and venerable authority from that source. The poem of the Mahabharata appears, in the geographical fragment Bhischmakanda, to describe "Meru" not so much as a mountain as an enormous elevation of the land, which supplies with water at once the sources of the Ganges, those of the Bliadrasoma (Irtysh), and those of the forked Oxus. These physico-geographical views were intermingled in Europe with ideas of other kinds, and with mythical reveries relating to the origin of mankind. It was said that the elevated regions from which the waters first retreated, (geologists in general were long averse to the theory of elevation), must also have received the first germs of civilisation. Hebraizing systems of geology, and views connected with the Deluge 
and supported by local traditions, favoured these assumptions. The intimate connection between time and space, between the beginnings of social order and the plastic character of the surface of the earth, lent to the supposed " uninterrupted Plateau of Tartary" a peculiar importance, and an almost moral interest. Acquisitions of positive knowledge, the late matured fruit of scientific travels and direct measurements, as well as of a fundamental study of Asiatic languages and literature especially those of China, have gradually demonstrated the inaccuracies and exaggerations of those wild hypotheses. The mountain plains (óporédıa) of Central Asia are no longer regarded as the cradle of civilization and the primitive seat of all arts and sciences. The ancient nation of Bailly's Atlantis, happily described by d'Alembert as "having taught us everything but their own name and existence," has vanished. The supposed inhabitants of the Oceanic Atlantis had already been treated, in the time of Posidonius, in a no less derisive manner. (Strabo, lib. ii. p. 102 ; and lib. xiii. p. 598, Casaub.)

A plateau of considerable but very unequal elevation, having the names of Gobi, Scha-mo (sand desert), Scha-ho (sand river), and Hanhai, runs in a SSW.-NNE. direction, with little interruption, from Eastern Thibet towards the mountain knot of Kentei south of Lake Baikal. This swelling of the ground is probably anterior to the elevation of the mountain chains by which it is intersected; it is situated, as already remarked, between $79^{\circ}$ and $116^{\circ}$ long. from Paris, $\left(81^{\circ}\right.$ and $118^{\circ}$ E. from Greenwich). Measured at right angles to its longitudinal axis, its breadth 
is, in the south between Ladak, Gertop, and H'lassa, (the seat of the great $\left.T_{\text {ama, }}\right) 720$ geographical miles; between Hami in the Celestial Mountains, and the great bend of the Hoang-ho near the In-schan chain, hardly 480 ; and in the north, between the Khanggai, where the great city of Karakhorum once stood, and the chain of Khin-gan-Petscha, which runs north and south (in the part of the Gobi traversed in travelling from Kiachta by Urga to Pekin) 760 geographical miles. The whole extent of this swelling ground, which must be carefully distinguished from the far more elevated mountain range to the east, may be approximately estimated, taking its inflections into account, at about three times the area of France. The map of the mountain ranges and volcanoes of Central Asia (Carte der Bergketten und Vulkane von Central-Asien), constructed by me in 1839, but not published until 1843, shows in the clearest manner the hypsometric relations between the mountain ranges and the Gobi plateau. It was founded on the critical employment of all the astronomical determinations accessible to me, and on a vast amount of orographic description, in which Chinese literature is beyond measure rich, examined at my request by Klaproth and Stanislas Julien. My map marks the mean direction and the height of the mountain chains, and represents the leading features of the interior of the continent of Asia, from $30^{\circ}$ to $60^{\circ}$ degrees of north latitude, and between the meridians of Kherson and Pekin. It differs materially from any previously published map.

The Chinese have enjoyed a threefold advantage towards 
the collection of so great an amount of orographic data in the highlands of Asia, and more especially in the regions (hitherto so little known in the west), north and south of the Celestial mountains, between the In-schan, the mountain lake Khuku-noor, and the banks of the Ili and the Tarim. The three advantages I allude to are,- the military expeditions towards the west, (under the dynasties of Han and Thang 122 years before our era, and again in the ninth century when conquerors advanced as far as Ferghana and to the borders of the Caspian), together with the more peaceful conquests of Buddhistic pilgrims;-the religious interest attaching to certain lofty mountain summits on account of sacrifices to be periodically offered there;-and the early and general use of the compass in giving the directions of mountains and of rivers. The knowledge and use of the "South pointing" of the magnetic needle twelve centuries before our era, has given to the orographic and hydrographic descriptions of countries by the Chinese, a great superiority over the descriptions of the same kind which Greek or Roman writers have bequeathed to us, and which are besides extremely few. The acute and sagacious Strabo, was alike imperfectly acquainted with the direction of the Pyrenees, and with those of the Alps and of the Appennines. (Compare Strabo, lib. ii. p. 71 and 128 ; lib. iii. p. 137 ; lib. iv. p. 199 and 202 ; lib. v. p. 211, Casaub.) To the lowlands belong almost the whole of Northern Asia to the north-west of the volcanic chain of the Thian-schan ;the Steppes to the north of the Altai and of the Sayan chain; - the countries which extend from the mountains of 
Bolor, or Bulyt-Tagh, (" cloud mountains" in the Uigurian dialect) which follow a north and sonth direction, and from the upper Oxus, (whose sources were found by the Buddhistic pilgrims Hiuen-thsang and Song-yun in 518 and 629, by Marco Polo in 1277, and by Lieutenant Wood in 1838, in the Pamer Lake, Sir-i-kol, Lake Victoria), towards the Caspian; and from Tenghir or the Balkhash Lake through the Kirghis Steppe, towards the sea of Aral and the southern extremity of the Ural mountains. As compared with high plains of 6,000 to 10,000 feet above the level of the sea, it may well be permitted to use the expression of "lowlands" for flats of little more than 200 to 1200 feet of elevation. The lowest of the last two numbers corresponds nearly to the altitude of the town of Mannheim, and the highest to that of Geneva and Tubingen. If the word plateau, so often misemployed in modern works on geography, is to have its use extended to elevations which hardly present any sensible difference in climate and vegetation, the indefiniteness of the expressions "highlands and lowlands," which are only relative terms, will deprive physical geography of the means of expressing the idea of the connection between elevation and climate, between the profile or relief of the ground and the decrease of temperature. When I found myself in Chinese Dzungarei, between the boundary of Siberia and Lake Dsaisang, at an equal distance from the Icy Sea and from the mouth of the Ganges, I might well consider myself in Central Asia. The barometer, however, soon taught me that the plains through which the Upper Irtysh flows, between Ustkamenogorsk and the Chinese 
Dzungarian Post, Chonimailachu, (sheep-bleating,) are scarcely raised 850 , or at the most 1170 , feet above the level of the sea. Pansner's older barometric measurements (which, however, were not published until after my expedition), are confirmed by mine. Both refute the hypothesis of Chappe, relative to the supposed high elevation of the banks of the Irtysh, in Southern Siberia; an hypothesis based on estimations of river declivities. Even further to the East, Lake Baikal is only 222 toises, or 1420 English feet, above the level of the sea.

In order to connect the idea of the relation of the terms lowlands and highlands and of the various gradations in the height of elevated plains or undulating grounds, with actual examples ascertained by measurement, I have subjoined a table, forming an ascending scale of such districts in different parts of the Globe. What I have said above respecting the mean height of those Asiatic $\mathrm{p}$ ains, which I have termed lowlands, may be compared with the following numbers :-

\begin{tabular}{|c|c|c|}
\hline & Toises. & English \\
\hline Plate & of Auvergne & 1087 \\
\hline " & of Bavaria $\ldots \ldots \ldots$ & 1663 \\
\hline " & of Castille $\ldots \ldots \ldots$ & 2239 \\
\hline " & $\ldots \ldots \ldots \ldots \ldots 460$ & 2942 \\
\hline " & of Caraccas . . . . . . . . . . . 480 & 3070 \\
\hline * & of Popayan . . . . . . . . . . . . 900 & 5756 \\
\hline “ & round Lake Tzana (in Abyssinia) . . & 6076 \\
\hline “ & of the Orange River (in South Africa) 1000 & 6395 \\
\hline “ & of Axum (in Abyssinia) . . & 7034 \\
\hline “ & of Mexico & 7483 \\
\hline “ & 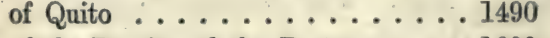 & 9528 \\
\hline “ & of the Province de los Pastos . . . . 1600 & 10231 \\
\hline “ & round Lake Titiacia . . . . . . . . . . 2010 & 12853 \\
\hline
\end{tabular}


No portion of the so-called Desert of Gobi (parts of which contain fine pastures) has been so thoroughly explored in respect to the differences of elevation as the zone, of nearly 600 geographical miles in breadth, between the sources of the Selenga and the great Wall of China. A very exact series of barometric levellings was executed under the auspices of the Academy of St. Petersburgh by two distinguished Savans, the astronomer George Fuss, and the botanist Bunge. In the year 1832 they accompanied the mission of Greek monks to Pekin, to establish there one of the magnetic stations recommended by me. The mean height of this part of Gobi does not amount, as had been too hastily inferred from the measurement of neighbouring summits by the Jesuits Gerbillon and Verbiest to from 7500 to 8000 French ( 8000 to 8500 English) feet, but only to little more than half that height, or barely 4000 French or 4264 English feet. Between Erghi, Durma, and Scharaburguna, the ground is only 2400 French, or 2558 English, feet above the level of the sea, or hardly 300 French (320 English) feet higher than the plateau of Madrid. Erghi is situated midway, in lat. $45^{\circ} 31^{\prime}$, long. $111^{\circ} 26^{\prime} \mathrm{E}$. from Greenwich. There is here a depression of more than 240 miles in breadth, in a SW. and NE. direction. An ancient Mogul tradition marks it as the bottom of a former inland sea. There are found in it reeds and saline plants, mostly of the same kinds as those on the low shores of the Caspian. In this central part of the desert there are small salt lakes, from which salt is carried to China. According to a singular opinion very 
prevalent among the Moguls, the ocean will one day return and establish its empire anew in Gobi. One is reminded of the Chinese tradition of the bitter lake, in the interior of Siberia, mentioned by me in another work. (Humboldt, Asie Centrale, tom. ii. p. 141; Klaproth, Asia Polyglotta, p. 232.) The valley or basin of Kashmeer, so enthusiastically extolled by Bernier, and but too moderately praised by Victor Jacquemont, has also given occasion to great hypsometric exaggerations. By a careful barometrical measurement, Jacquemont found the height of the Wulur Lake in the valley of Kashmeer, not far from the chief city Sirinagur, 836 toises, or 5346 English feet. Uncertain determinations by the boiling point of water gave Baron Carl von Hügel a result of 910, and Lieutenant Cunningham only 790 toises. (Compare my Asie Centrale, tom. iii. p. 310, with the Journal of the Asiatic Society of Bengal, vol. x.1841,p. 114.) Kashmeer,-respecting which, in Germany particularly, so much interest has been felt, but the delightfulness of whose climate is considerably impaired by four months of winter snow in the streets of Sirinagur (Carl von Hügel, Kaschmir, Bd. ii. S. 196), -is not situated, as is often supposed, upon the ridge of the Himalaya, but is a true cauldron-shaped valley (Kesselthal, Caldera,) on the southern declivity of those mountains. On the southwest, where the rampart-like elevation of the Pir Panjal separates it from the Punjaub, the snow-covered summits are crowned, according to Vigne, with formations of basalt and amygdaloid. The latter formation has received from the natives the characteristic name of "schischak 
deyu," marked by the devil's small-pox. (Vigne, Travels in Kashmeer, 1842, vol. i. p. 237-293.) The beauty of its vegetation has from the earliest times been very differently described, according as the visitor came from the rich and luxuriant vegetation of India, or from the northern regions of Turkestan, Samarcand, and Ferghana.

It is also only very recently that clearer views have been obtained respecting the elevation of Thibet; the level of the plateau having long been most uncritically confounded with the summits which rise from it. Thibet occupies the interval between the two great chains of the Himalaya and the Kuen-lün, forming the raised ground of the valley between them. It is divided from east to west, both by the natives and by Chinese geographers, into three portions. Upper Thibet, with its capital city H'lassa, probably 1500 toises (9590 English feet) above the level of the sea;Middle Thibet, with the town of Leh or Ladak (1563 toises, or 9995 English feet);-and Little Thibet, or Baltistan, called the Thibet of Apricots, (Sari Boutan), in which are situated Iskardo (985 toises, or 6300 English feet), Gilgit, and south of Iskardo but on the left bank of the Indus, the plateau of Deotsuh, measured by Vigne, and found to be 1873 toises, or 11,977 English feet. On examining all the notices that we possess respecting the three Thibets, (and which will have received in the present year a rich augmentation by the boundary expedition under the auspices of the governor-general, Lord Dalhousie), we soon become convinced that the region between the Himalaya and the Kuenlün is no unbroken plain or table land, but that it is intervoL. I. 
sected by mountain groups, undoubtedly belonging to wholly distinct systems of elevation. There are, properly speaking, very few plains; the most considerable are those between Gertop, Daba, Schang-thung (Shepherd's Plain) the native country of the Shawl-goat, and Schipke (1634 toises, 10,450 English feet); - those round Ladak, which have an elevation of 2100 toises, or 134:30 English feet, and must not be confounded with the depression in which the town is situated;-and lastly, the plateau of the Sacred Lakes Manasa and Ravanahrada (probably 2345 toises), which was visited so early as 1625 by Pater Antonio de Andrada. Other parts are entirely filled with crowded mountainous elevations, "rising," as a recent traveller expresses it, "like the waves of a vast ocean." Along the rivers, the Indus, the Sutlej, and the Yaru-dzangbo-tschu which was formerly regarded as identical with the Brahma-putra, points have been measured which are only between 1050 and 1400 toises (6714 and 8952 English feet) above the level of the sea; so also with respect to the Thibetian villages of Pangi, Kunawur, Kelu, and Murung. (Humboldt, Asie Centrale, T. iii. p. 281-325.) From many carefully collected measurements of elevation I think I may conclude that the plateau of Thibet, between $73^{\circ}$ and $85^{\circ} \mathrm{E}$. long., does not reach a mean height of 1800 toises (11510 English feet); this is hardly equal to the height of the fertile plain of Caxamarca in Peru, and is 211 and 337 toises (1350 and 2154 English feet) less than the height of the plateau of Titicaca, and the street pavement of the Upper Town of Potosi (2137 toises, 13,665 English feet). 
That outside of the Thibetian highlands and of the Gobi, the boundaries of which have been defined above, there are in Asia, between the parallels of $37^{\circ}$ and $48^{\circ}$, considerable depressions and even true lowlands, where one boundless uninterrupted plateau was formerly imagined to exist, is shewn by the cultivation of plants which cannot thrive without a certain degree of heat. An attentive study of the travels of Marco Polo, in which the cultivation of the vine and the production of cotton in northern latitudes are spoken of, had long called the attention of the acute Klaproth to this point. In a Chinese work, entitled "Information respecting the recently-subdued Barbarians (Sin-kiang-waitan-ki-lio)," it is said, "the country of Aksu, somewhat to the south of the Celestial Mountains (the Thian-schan), near the rivers which form the great Tarim-gol, produces grapes, pomegranates, and numberless other excellent fruits; also cotton (Gossypium religiosum), which covers the fields like yellow clouds. In the summer the heat is exceedingly great, and in winter there is here, as at Turfan, neither severe cold nor heavy snow.” The district round Khotan, Kashgar, and Yarkand, still pays its tribute in home-grcwn cotton as it did in the time of Marco Polo. (Il Milione di Marco Polo, pubbl. dal Conte Baldelli, T. i. p. 32 and 87.) In the Oasis of Hami (Khamil), above 200 miles east of Aksu, orange trees, pomegranates, and vines whose fruit is of a superior quality, grow and flourish.

The products of cultivation which are thus noticed imply the existence of only a small degree of elevation, and that over extersive districts. At so great a distance from 
any coast, and in those easterly meridians where the cold of winter is known to exceed that of corresponding latitudes nearer our own part of the world, a plateau which should be as high as Madrid or Munich might indeed have very hot summers, but would hardly have, in $43^{\circ}$ and $44^{\circ}$ latitude, extremely mild winters with scarcely any snow. Near the Caspian, 83 English feet below the level of the Black Sea, at Astrachan in $46^{\circ} 21^{\prime}$ lat., I saw the cultivation of the vine greatly favoured by a high degree of summer heat; but the winter cold is there from $-20^{\circ}$ to $-25^{\circ}$ Cent. $\left(-4^{\circ}\right.$ to $-13^{\circ}$ Fahr.) It is therefore necessary to protect the vines after November, by sinking them deep in the earth. Plants which live, as we may say, only in the summer, as the vine, the cotton bush, rice, and melons, may indeed be cultivated with success between the latitudes of $40^{\circ}$ and $44^{\circ}$ on plains of more than 500 toises (3197 English feet) elevation, being favoured by the powerful radiant heat; but how could the pomegranate trees of $\mathrm{Aksu}$, and the orange trees of Harni, whose fruit Père Grosier extolled as distinguished for its goodness, bear the cold of the long and severe winter which would be the necessary consequence of a considerable elevation of the land? (Asie Centrale, T. ii. p. 48-52, and 429.) Carl Zimmerman (in the learned Analysis of his "Karte von Inner Asien," 1841, S. 99) has made it appear extremely probable that the Tarim depression, $i$. e. the desert between the mountain chains of the Thian-schan and the Kuen-liin, where the Steppe river Tarim-gol empties itself into the Lake of Lop, which used to be described as an alpine lake, is hardly 1200 (1279 English) feet above the level of the sea, or only twice 
the height of Prague. Sir Alexander Burnes also assigns to that of Bokhara only an elevation of 1190 English feet. It is earnestly to be desired, that all doubt respecting the elevation of the plateaux of middle Asia, south of $45^{\circ}$ of latitude, should finally be set at rest by direct barometric measurements, or by determinations of the boiling point of water made with more care than is usually given to them. All our calculations respecting the difference between the limits of perpetual snow, and the maximum elevation of vine cultivation in different climates, rest at present on too complex and uncertain elements.

In order to rectify in the smallest space that which was said in the last edition of the present work, relatively to the great mountain systems which intersect the interior of Asia, I subjoin the following general review. We begin with the four parallel chains, which follow with tolerable regularity an east and west direction, and are connected with each other at a few detached points by transverse elevations. Differences of direction indicate, as in the Alps of western Europe, a difference in the epoch of elevation. After the four parallel chains (the Altai, the Thianschan, the Kuen-lün, and the Himalaya), we have to notice chains following the direction of meridians, viz. the Ural, the Bolor, the Khingan, and the Chinese chains, which, with the great bend of the Thibetian and AssamoBermese Dzangbo-tschu, run north and south. The Ural divides a part of Europe but little elevated above the level of the sea from a part of Asia similarly circumstanced. The latter was called by Herodotus, (ed. Schweig- 
haüser, T. v. p. 204) and even as early as Pherecydes of Syros, a Scythian or Siberian Europe, including all the countries to the north of the Caspian and of the Iaxartes; in this view it would be a continuation of Europe "prolonged to the north of Asia."

1. The great mountain system of the Altai, (the "gold mountains" of Menander of Byzantium, an historical writer who lived as early as the 7th century, the Altaï-alin of the Moguls, and the Kin-schan of the Chinese), forms the southern boundary of the great Siberian lowlands; and running between $50^{\circ}$ and $52 \frac{1}{2}^{\circ}$ of north latitude, extends from the rich silver mines of the SnakeMountains, and the confluence of the Uba and the Irtysh, to the meridian of Lake Baikal. The divisions and names of the "Great" and the "Little Altai," taken from an obscure passage of Abulghasi, are to be altogether avoided. (Asie Centrale, T. i. p. 247.) The mountain system of the Altai comprehends $(a)$ the Altai proper, or Kolywanski Altai, the whole of which is under the Russian sceptre; it is west of the transverse opening of the Telezki Lake, which follows the direction of the meridian; and in ante-historic times probably formed the eastern shore of the great arm of the sea, by which, in the direction of the still existing groups of lakes, Aksakal-Barbi and Sary-Kupa (Asie Centrale, T. ii. p. 138), the Aralo-Caspian basin was counected with the Icy sea :- $(b)$ East of the Telezki chain which follows the direction of the meridian, the Sayani, Tangnu, and Ulangom or Malakha chains, all running tolerably parallel with each other and in an east and west direction. The Tangnu, which sinks down and terminates 
in the basin of the Selenga, has from very ancient times formed a boundary between the Turkish race to the south and the Kirghis (Hakas, identical with $\Sigma$ ákaı) in the north. (Jacob Grimm, Gesch. der deutschen Sprache, 1848, Th. i. S. 227.) It is the original seat of the Samoieds or Soyotes, who wandered as far as the Icy Sea, and who were long regarded in Europe as a nation belonging exclusively to the coasts of the Polar Sea. The highest snow-clad summits of the Altai of Kolywan are the Bielucha and the KatuniaPillars. The height of the latter is about that of Etna. The Daurian highland, to which the mountain knot of Kemtei belongs, and on the eastern side of which is the Jablonoi Chrebet, divides the depressions of the Baikal and the Amur.

2. The mountain system of the Thian-schan, or Celestial Mountains, the Tengri-tagh of the Turks (Tukiu) and of the kindred race of the Hiongnu, is eight times as long, in an east and west direction, as the Pyrenees. Beyond,-i.e west of its intersection with the transverse or north and south chain of the Bolor and Kosuyrt, the Thian-schan bears the names of Asferah and Aktagh, is rich in metals, and has open fissures, which emit hot vapours, luminous at night, and which are used for obtaining sal-ammoniac. (Asie Centrale, T. ii. p. 18-20.) East of the transverse Bolor and Kosyurt chain, there follow successively in theThian-schan,the Kashgar Pass (Kaschgar-dawan); the Glacier Pass of Djeparle, which leads to Kutch and Aksu in the Tarin basin; the volcano of Pe-schan, which sent forth fire and streams of lava at least as late as the middle of the seventh century; the 
great snow-covered massive elevation Bogdo-Oola ; the Solfatara of Urumsti, which furnishes sulphur and sal-ammoniac (nao-scha), and is situated in a coal district; the still active volcano of Turfan (or volcano of Ho-tscheu or Bischbalik), almost midway between the meridians of Turfan (Kune-Turpan), and of Pidjan. The volcanic eruptions of the Thian-schan chain, recorded by Chinese historians, reach as far back as the year 89, A.D., when the Hiongnu of the sources of the Irtysh were pursued by the Chinese army as far as Kutch and Kharaschar (Klaproth, Tableau hist. de l'Asie, p. 108). The Chinese General, Teu-hian, surmounted the Thian-schan, and saw " the Fire Mountains which send out masses of molten rock that flow for many Li."

The great distance from the sea of the volcanoes of the interior of Asia is a remarkable and solitary phenomenon. Abel Rémusat, in a letter to Cordier (Annales des Mines, T. v. 1820, p. 137), first directed the attention of geologists to this fact. The distance, for example, in the case of the volcano of Pe-schan, to the north, or to the Icy Sea at the mouth of the Obi, is 1528 geographical miles; to the south, or to the mouths of the Indus and the Ganges, 1512 geographical miles ; to the west, 1360 geographical miles to the Caspian in the Gulf of Karaboghaz ; and to the east, 1020 geographical miles to the shores of the sea of Aral. The active volcanoes of the New World were previously supposed to offer the most remarkable instances of such phenomena at a great distance from the sea ; their distance, however, is only 132 geographical miles in the case of the volcano of Popo- 
catepetl in Mexico, and only 92, 104, and 156 geographical miles in those of the South American volcanoes Sangai, Tolima, and de la Fragua, respectively. I exclude from these statements all extinct volcanoes, and all trachytic mountains which have no permanent connection with the interior of the earth. (Asie Centrale, T. ii. p. 16-55, 69-77, and 341356.) East of the volcano of Turfan, and of the fertile Oasis of Hami rich in fine fruit, the chain of the Thianschan gives place to the great elevated tract of Gobi which follows a S.W. and N.E. direction. This interruption of the mountain chain, caused by the transverse intersection of the Gobi, continues for more than $9 \frac{1}{2}$ degrees of longitude ; but beyond it the mountains recommence in the somewhat more southerly chain of the In-schan, or the Silver Mountains, running (north of the Pe-tscheli) from west to east almost to the shores of the Pacific near Pekin, and forming a continuation of the Thian-schan. As I have viewed the In-schan as an easterly prolongation (beyond the interruption of the Gobi) of the cleft above which theThian-schan stands,so one might possibly view the Cancasus as a westerly prolongation of the same, beyond the great basin of the Aral andCaspian Seas or the depression of Turan. The mean parallel of latitude or axis of elevation of the Thian-schan oscillates between $40 \frac{2}{3}^{\circ}$ and $43^{\circ} \mathrm{N}$. lat. ; that of the Caucasus, according to the map of the Russian Etat-Major (running rather E.S.E. and W.N.W.), is between $41^{\circ}$ and $44^{\circ} \mathrm{N}$. lat. (Baron von Meyendorff, in the Bulletin de la Societé géologique de France, T. ix. 1837-1838, p. 230.) Of the four parallel chains which traverse Asia from east to west, the Thian- 
schan is the only one in which no summits have yet had their elevation above the sea determined by measurement.

3. The mountain system of the Kuen-lün (Kurkun or Kulkun), if we include in it the Hindu-Coosh and its western prolongation in the Persian Elbourz and Demavend, is, next to the American Cordillera of the Andes, the longest line of elevation on the surface of our planet. Where the northand-south chain of Bolor intersects the Kuen-lün at right angles, the latter takes the name of the Thsung-ling (Onion Mountains), which is also given to a part of the Bolor at the eastern angle of intersection. The Kuen-lün, forming the northern boundary of Thibet, runs very regularly in an east and west direction, in the latitude of $36^{\circ}$. In the uneridian of $\mathrm{H}^{\prime}$ lassa an interruption takes place from the great mountain knot which surrounds the alpine lake of Khuku-noor, the Sing-so-hai, or Starry Sea, so celebrated in the mythical geography of the Chinese. The somewhat more northerly chains of Nan-schan and Kilian-schan may almost be regarded as an easterly prolongation of the Thian-schan. They extend to the Chinese wall near Liang-tscheu. West of the intersection of the Bolor and Kuen-lün (the Thsungling) I think I have been the first to shew (Asie Centrale, T. i. p. 23, and 118-159; T. ii. p. 431-434 and 465) that the corresponding direction of the axes of the Kuen-liun and the Hindu-Coosh (both being east and west, whereas the Himalaya is south-east and north-west) makes it reasunable to regard the Hindu-Coosh as a continuation, not of the Himalaya, but of the Kuen-lün. From the Taurus in Lycia to Kafiristan, through an extent of 45 degrees of longitude, 
this chain follows the parallel of Rhodes, or the diaphragm of Dicearchus. The grand geognostical view of Erastosthenes (Strabo, Lib. ii. p. 68; Lib. xi. p. 490 and 511; and Lib. xv. p. 689), which is farther developed by Marinus of Tyre, and Ptolemy, and according to which " the continuation of the Taurus in Lycia extends across the whole of Asia to India, in one and the same direction," appears to have been partly founded on statements which reached the Persians and Indians from the Punjaub. "The Brahmins affirm," says Cosmas Indicopleustes, in his Christian Topography, (Mountfauçon, Collectio nova Patrum, T. ii. p. 137) "that a line drawn from Tzinitza (Thinæ) across Persia and Romania, exactly cuts the middle of the inhabited earth." It is deserving of notice that Eratosthenes had so early remarked that this longest axis of elevation in the Old Continent, in the parallels of $35 \frac{1}{2}^{\circ}$ and $36^{\circ}$, points directly through the basin (or depression) of the Mediterranean to the Pillars of Hercules. (Compare Asie Centrale, T. i. p. 23 and 122138; T. ii. p. 430-434, with Kosmos, Bd. ii. S. 222 and 438, p. 188, and note 292,Engl. ed.) The easternmost part of the Hindu-Coosh is the Paropanisus of the ancients, the Indian Caucasus of the companions of Alexander. The now generally used term of Hindu-Coosh, belongs, as may be seen from the Travels of the Arab Ibn Batuta (English version, p. 97), to a single mountain pass on which many Indian slaves often perished from cold. The Kuen-lün, like the Thian-schan, shews igneous outbreaks or eruptions at many hundred miles from the sea. Flames, visible at a great distance, issue from a avcity in the Schin-khieu Mountain. 
(Asie Centrale, T. ii. p. 427 and 483, where I have followed the text of Yuen-thong-ki, translated by my friend Stanislas Julien.) The highest summit measured in the HinduCoosh, north-west of Jellalabad, is 3164 toises above the sea (20132 English feet); to the west, towards Herat, the chain sinks to 400 toises (2558 English feet), until, north of Teheran, it rises again to a height of 2295 toises (14675 English feet) in the volcano of Demavend.

4. The mountain system of the Himalaya. The normal direction of this system is east and west when followed from $81^{\circ}$ to $97^{\circ} \mathrm{E}$. long. from Greenwich, or through more than fifteen degrees of longitude from the colossal Dhawalagiri (4.390 toises, 28071 English feet) to the breaking through of the long-problematical Dzangbo-tschu river (the Irawaddy, according to Dalrymple and Klaproth), and to the chains running north and south which cover the whole of Western China, and in the provinces of Sse-tschuan, Hu-kuang, and Kuang-si form the great mountain group of the sources of the Kiang. The next highest culminating point to the Dhawalagiri, of this east and west part of the Himalaya, is not, as has been hitherto supposed, the eastern peak of the Schamalari, but the Kinchinjinga. This mountain is situated in the meridian of Sikhim, between Bootan and Nepaul, and between the Schamalari (3750 ? toises, 23980 English feet) and the Dhawalagiri : its height is 44.06 toises, or 26438 Parisian, or 28174 English feet. It was first measured accurately by trigonometrical operations in the present year, and as the account of this measurement received by me from India says decidedly, "that a new determination. 
of the Dhawalagiri leaves to the latter the first rank among all the snow-capped mountains of the Himalaya," the height of the Dhawalagiri must necessarily be greater than that of 4390 toises, or 26340 Parisian, 28071 English feet, hitherto ascribed to it. (Letter of the accomplished botanist of Sir James Ross's Antarctic Expedition, Dr. Juseph Hooker, written from Dorjiling, July 25, 1848.) The turning point in the direction of the axis of the Himalaya range is not far from the Dhawalagiri, in $79^{\circ} \mathrm{E}$. long. from Paris ( $81^{\circ} 22^{\prime}$ Greenwich). From thence to the westward the Himalaya no longer runs east and west, but from SE. to NW., connecting itself, as a great cross vein, between Mozuffer-abad and Gilgit south of Kafiristan, with a part of the Hindu-Coosh. Such a bend or change in the direction or strike of the axis of elevation of the Himalaya (from E-W. to SE-NW.), doubtless points, as in the western part of our European Alps, to a difference in the age or epoch of elevation. The course of the Upper Indus, from the sacred lakes Manasa and Ravana-hrada (at an elevation of 2345 toises, 14995 English feet) in the vicinity of which the great river rises, to Iskardo and to the plateau of Deo-tsuh, (at an elevation of 2032 toises, 12993 English feet) measured by Vigne, follows in the Thibetian highlands the same north-westerly direction as the Himalaya. Here is the summit of the Djawahir, long since well measured and known to be 4027 toises (25750 English feet) in elevation, and the valley of Kashmeer, where at an elevation of only 836 toises, (5346 English feet), the Wulur Lake freezes every winter, and, from the perpetual calm, no wave ever curls its surface. 
Having thus described the four great mountain systems of Asia, which in their normal geognostic character are chains coinciding with parallels of latitude, I have next to speak of the series of elevations coinciding nearly with meridians, (or more precisely, having a SSE.-NNW. direction), which, from Cape Comorin opposite to the Island of Ceylon to the Icy Sea, alternate between the meridians of $66^{\circ}$ and $77^{\circ}$ E. long. from Greenwich. To this system, of which the alternations remind us of faults in veins, belong the Ghauts, the Soliman chain, the Paralasa, the Bolor, and the Ural. The interruptions of the series of elevations are so arranged that, beside their alternate position in respect to longitude, each new chain begins in a degree of latitude to which the preceding chain had not quite reached. The importance which the Greeks (although probably not before the second century) attached to these chains induced Agathodemon and Ptolemy 'Tab. vii. and viii.) to represent to themselves the Bolor, under the name of Imaus, as an axis of elevation extending as far as $62^{\circ} \mathrm{N}$. lat. into the low basin of the Lower Irtisch and the Obi. (Asie Centrale, T. i. p. 138, 154, and 198; T. ii. p. 367.)

As the perpendicular elevation of mountain summits above the level of the sea (unimportant as in the eyes of the geologist the circumstance of the greater or lesser corrugation of the crust of the earth may be), is still, like all that is difficult of attainment, an object of popular curiosity, the following historical notice of the gradual progress of hypsometric knowledge may here find a suitable place. When I returned to Europe in 1804 after a four years' absence, not a single Asiatic snowy summit either in the Himalaya, the 
Hindu-Coosh, or the Caucasus, had been measured with any exactness; and I could not therefore compare my determinations of the height of perpetual snow in the Cordilleras of Quito, or the mountains of Mexico, with any corresponding determinations in the East. The important journey of Turner, Davis, and Saunders, to the highlands of Thibet, does indeed belong to the year 1783, but Colebrooke justly remarks, that the elevation given by Turner to the Schamalari (lat. $28^{\circ} 5^{\prime}$, long. $89^{\circ} 30^{\prime}$, a little to the north of Tassisudan) rests on foundations as slight as those of the so-called measurements of the heights seen from Patna and the Kafiristan by Colonel Crawford and Lieutenant Macartney. (Compare Turner, in the Asiatic Researches, vol. xii. p. 234, with Elphinstone's Account of the Kingdom of Caubul, 1815, p. 95, and Francis Hamilton, Account of Nepal, 1819, p. 92.) The excellent observations and writings of Webb, Hodgson, Herbert, and the brothers Gerard, have thrown great and certain light on the elevation of the colossal summits of the Himalaya ; yet, in 1808, the hypsometric knowledge of this great Indian chain was still so uncertain that Webb wrote to Colebrooke: "The height of the Himalaya still remains a problem. I find, indeed, that the summits visible from the high plain of Rohilcund are 21000 English feet above that plain, but we do not know the absolute height above the sea."

It was not until the beginning of the year 1820 that it began to be reported in Europe, that not only were there in the Himalaya, summits much higher than those of the Cordilleras, but also that Webb had seen in the Pass of Niti, 
and Moorcroft in the Thibetian plateau of Daba and the Sacred Lakes, fine pastures and flourishing fields of corn, at altitudes far exceeding the height of Mont Blanc. These accounts were received in England with much incredulity, and were met by doubts respecting the influence of refraction. I have shown the groundlessness of these doubts in two memoirs (Sur les Montagnes de l'Inde), printed in the Annales de Chimie et de Physique. The Tyrolese jesuit, P. Tiefenthaler, who in 1766 penetrated into the provinces of Kemaun and Nepal, had already divined the importance of the Dhawalagiri. We read on his map, "Montes Albi, qui Indis Dolaghir, nive obsiti.” Captain Webb always uses the same name. Until the measurements of the Djawahir (lat. $30^{\circ} 22^{\prime}$, long. $79^{\circ} 58^{\prime}$, altitude 4027 toises, or 25750 English feet) and of the Dhawalagiri (lat. $28^{\circ} 40^{\prime}$, long. $83^{\circ}$ $21^{\prime}$, altitude 4390 ? toises, 28072 English feet) were made known in Europe, the Chimborazo (3350 toises, or 21421 English feet), according to my trigonometric measurement, (Recueil d'Observations astronomiques, T. i. p. 73) was still everywhere regarded as the highest summit on the surface of the earth. The Himalaya now appeared, according as the comparison was made with the Djawahir or the Dhawalagiri, 676 toises (4323 English feet), or 1040 toises (6650 English feet), higher than the Chimborazo. Pentland's South American travels, in the years 1827 and 1838, fixed attention (Annuaire du Bureau des Longitudes, 1830, p. 320 and 323) on two snowy summits of Upper Peru, east of the Lake of Titicaca, which were supposed to surpass the height of the Chimborazo respectively by 598 and 4.03 
toises, (3824 and 2577 English feet.) I have remarked above, pp. 53-54, that the latest calculation of the measurements of the Sorata and Illimani shews this view to be incorrect. The Dhawalagiri (on the declivity of which, in the valley of the Ghandaki, the Salagrana Ammonites, so celebrated among the Brahmins as symbols of one of the incarnations of Vishnu, are collected) therefore still shews a difference between the culminating points of the Old and the New Continents of more than 6200 Parisian, or 6608 English feet.

The question has been raised, whether there may not exist behind the southernmost more or less perfectly measured chain, other still greater elevations. Colonel George Lloyd, who in 1840 edited the important observations of Captain Alexander Gerard and his brother, entertains an opinion that in the part of the Himalaya which he calls somewhat vaguely "the Tartaric chain," (Ineaning therefore in north Thibet towards the Kuen-lün, and perhaps in Kailasa of the sacred lakes, or beyond Leh) there are summits of from 29000 to 30000 English feet,-one or two thousand feet higher therefore than the Dawalagiri. (Lloyd and Gerard, Tour in the Himalaya, 1840, vol. i.p. 143 and 312; Asie Centrale, T. iii. p. 324.) So long as actual measurements are wanting, one cannot decide respecting such possibilities; as the indication, from which the natives of Quito, long before the arrival of Bouguer and $\mathrm{La}$ Condamine, recognised the superior altitude of the Chimborazo (namely, from the portion of its height above the region of perpetual snow being greater than in any of the other mountains), might vol. I. 
prove very deceptive in the temperate zone of Thibet, where radiation is so active in the table-land, and where the lower limit of perpetual snow does not form a regular line at an equal elevation, as it does in the tropics. The greatest elevation above the level of the sea ever attained by human beings on the declivity of the Himalaya, is 3035 toises, or 18210 Parisian, or 19409 English feet, reached by Captain Gerard, with seven barometers, on the mountain of Tarhigang, a little to the north-west of Schipke. (Colebrooke, in the Transactions of the Geological Society, vol. vi. p. 411.) This happens to be exactly the same height as that reached by myself on the 23rd of June, 1802, and thirty years later by my friend Boussingault, on the 16th of December, 1831, on the declivity of the Chimborazo. The unattained summit of the Tarhigang is, however, 197 toises, or 1260 English feet, higher than that of the Chimborazo.

The passes across the Himalaya, leading from Hindostan into Chinese Tartary, or rather into Western Thibet, more particularly between the rivers of Buspa and Schipke or Langzing Khampa, are from 2400 to 2900 toises, or 15346 to 18544 English feet. In the chain of the Andes I found the pass of Assuay, between Quito and Cuenca on the Ladera de Cadlud, having a similar elevation, being 2428 toises, or 15526 English feet, high. A great part of the mountain plains of the interior of Asia would be buried throughout the year in perpetual snow and ice, if it were not, that by the great radiation of heat from the Thibetian plateau, by the constant serenity of the sky, by the rarity of the formation of snow in the dry atmosphere, and by the pow . 
erful solar heat peculiar to the eastern continental climate, the limit of perpetual snow is wonderfully raised on the northern slope of the Himalaya,-perhaps to 2600 toises, or 16625 English feet above the level of the sea. Fields of barley (Hordeum hexastichon) are seen in Kunawur up to 2300 toises, or 14707 English feet; and another variety of barley called Ooa, and allied to Hordeum cœleste, even much higher. Wheat succeeds extremely well in the Thibetian highlands up to 1880 toises, or 12022 English feet. On the northern declivity of the Himalaya, Captain Gerard found the upper limit of the higher birch woods ascend to 2200 toises, 14068 English feet; and small bushes which serve the inhabitants for fuel to warm their huts, attain, in the latitude of $30 \frac{3}{4}^{\circ}$ and $31^{\circ}$ of north latitude, a height of 2650 toises (16945 English feet), or almost 200 toises (1279 English feet) higher than the limit of perpetual snow under the equator. From the data hitherto collected it would follow, that we may take the lower limit of perpetual snow on the northern side of the Himalaya, on the average, and in round numbers, at 2600 toises, or about 16600 English feet; whilst on the southern declivity of the Himalaya the snowline sinks to 2030 toises, or about 13000 English feet.

But for this remarkable distribution of temperature in the upper strata of the atmosphere, the mountain plain of Western Thibet would be uninhabitable to the millions who dwell there. (Compare my Examination of the Limit of Perpetual Snow on the two declivities of the Himalava, in the Asie Centrale, T. ii. p. 435-437; T. iii. p. 281-326, 
and in Kosmos, Engl. ed. vol. i. note 403 ; S. 483 of the original.)

A letter which I have just received from India from Dr. Joseph Hooker, who is engaged in meteorological and geological researches, as well as those connected with the geography of plants, says: "Mr. Hodgson, who we regard here as the geographer best acquainted with the hypsometric relations of the snow ranges, completely recognises the correctness of your statement in the third part of the Asie Centrale, respecting the reason of the inequality in the height of the limit of perpetual snow on the northern and southern declivities of the Himalaya. In the 'trans Sutlej region' in $36^{\circ}$ lat. we often saw the snow limit only commence at an altitude of 20000 English feet, while in the passes south of the Brahmaputra, between Assam and Burman, in $27^{\circ}$ lat., where the most southern Asiatic snowy mountains are situated, the limit of perpetual snow sinks to 15000 English feet." I believe we ought to distinguish between the extreme and the mean heights, but in both we see manifested in the clearest manner the formerly contested differences between the Thibetian and the Indian declivities.

My statements respecting the mean height of the Snow-line in the Himalaya. (Asie Centrale, tom. iii. p. 326.) Paris feet. Eng. feet. Northern declivity 15600 ...16626 Southerm $\quad \because \quad 12180 . . .12981$

Difference $\overline{3420} \overline{3645}$
Bxtremes according to Dr. Joseph Hooker's letter.

Paris feet. Eng. feet. Northern declivity $18764 \ldots 20000$ Southern “ $14073 \ldots 15000$ Difference $\overline{4691} \overline{5000}$

The local differences vary still more, as may be seen from 
the list of extremes given in my Asie Centrale, T. iii. p. 295. Alexander Gerard saw the snow limit ascend, on the Thibetian declivity of the Himalaya, to 19200 Parisian feet (20465 English); and on the southern Indian declivity, Jacquemont once saw it, north of Cursali on the Jumnotri, even as low as 10800 Parisian (11,510 English) feet.

\section{(11) p. 6.- "A brown Pastoral Race, the Hiongnu."}

The Hiongnu (Hiong-nou), who Deguignes, and with him many historians, long considered to be the Huns, inhabited that vast region of 'lartary which is bounded on the east by Uo-leang-ho (the present Mantschu dominion), on the south by the Chinese wall, on the west by the U-siun territory, and on the north by the country of the Eleuthes. But the Hiongnu belong to the Turkish, and the Huns to the Finnish or Uralian race. The northern Huns, a rude pastoral people, unacquainted with agriculture, were dark brown (sunburnt); the southern Huns or Hajatelah, (called by the Byzantines Euthalites or Nepthalites, and dwelling along the eastern shore of the Caspian), had a fairer complexion. The latter cultivated the ground, and possessed towns. They are often called the white, or fair Huns, and d'Herbelot even declares them to be IndoScythians. On Punu, the Leader or Tanju of the Huns, and on the great drought and famine which, about 46 A.D., caused a part of the nation to migrate northwards, (see Deguignes, Histoire gén. des Huns, des Turcs, \&c., 1756, T. i. pt. i. p. 217 ; pt. ii. p. $111,125,223,447$.$) All the$ accounts of the Huns taken from the above-mentioned 
celebrated work have been subjected to a learned and strict examination by Klaproth. According to the result of this research the Hiongnu belong to the widely diffused Turkish races of the Altai and Tangnu Mountains. The name Hiongnu, even in the third century before the Christian era, was a general name for the Ti, Thu-kiu or Turks, in the north and north-west of China. The southern Hiongnu overcame the Chinese, and in conjunction with them destroyed the empire of the northern Hiongnu. These latter fled to the west, and this flight seems to have given the first impulse to the migration of nations in Middle Asia. The Huns, who were long confounded with the Hiongnu, (as the Uigures with the Ugures and the Hungarians), belonged, according to Klaproth, to the Finnish race of the Ural mountains between Europe and Asia, a race which was variously mingled with Germans, Turks, and Samoieds. (Klaproth, Asia Polyglotta, p. 183 and 211 ; Tableaux Historiques de l'Asie, p. 102 and 109.) The Huns (Ozvvo ) are first named by Dios nysius Perigetes, a writer who was able to obtain more accurate information respecting the interior of Asia, because, as a learned man born at Charax on the Arabian Gulf, Augustus had sent him back to the East to accompany thither his adopted son Caius Agrippa. Ptolemy, a century later, writes the word (Xoṽou) with a strong aspiration, which, as St. Martin observes, is found again in the geographical name of Chunigard.

$$
\text { (12) p. 7.- "No carved Stone." }
$$

On the banks of the Orinoco near Caicara where the 
forest region joins the plain, we have indeed found representations of the sun, and figures of animals, cut on the rocks : but in the Llanos themselves no traces of these rude memorials of earlier inhabitants have been discovered. It is to be regretted that we have not received any more complete and certain information respecting a monument which was sent to France to Count Maurepas, and which, according to Kalm, had been found by M. de Verandrier in the Prairies of Canada 900 miles west of Montreal, in the course of an expedition intended to reach the Pacific. (Kalm's Reise, Th. iii. S. 4i16.) This traveller found in the middle of the plain enormous masses of stone, placed in an upright position by the hand of man, and on one of them was something which was taken to be a Tartar inscription. (Archæologia: or Miscellaneous Tracts, published by the Society of Antiquaries of London, vol. viii., 1787, p. 304.) How is it that so important a monument has remained unexamined? Can it really have contained alphabetical writing? or is it not far more probably a pictorial history, like the supposed Phœnician inscription on the bank of the Taunton River? I consider it, however, very probable that these plains were once traversed by civilised nations : pyramidal sepulchral mounds, and entrenchments of extrsordinary length, found in various places between the Rocky Mountains and the Alleghanies, and on which Squier and Davis (in the "Ancient Monuments of the Mississipi Valley") are now throwing a new light, appear to confirm this supposition. (Relation Hist., T. iii. p. 155.) Verandrier had been sent on his expedition by the Chevalier de Beauharnois, 
the French Governor-general of Canada, in 1746. Several Jesuits in the city of Quebec assured Kalm that they had themselves had the supposed inscription in their hands: it was engraved upon a small tablet which had been let into a pillar of cut stone, in which position it was found. I have asked several of my friends in France to search out this monument, in case it should really be in existence in the collection of Count Maurepas, but without success. I find older, but equally doubtful, statements as to the existence of alphabetical inscriptions belonging to the primitive nations of America, in Pedro de Cieça de Leon, Chronica del Peru, P. i. cap. 87 (losa con letras en los edificios de Vinaque); in Garcia, Origen de los Indios, 1607, lib. iii. cap. 5, p. 258 ; and in Columbus's Journal of his first voyage, in Navarrete, Viages de los Espanoles, T. i. p. 67. M. de Verandrier moreover affirmed, (and earlier travellers had also thought they had observed the same thing), that in the prairies of Western Canada, throughout entire days' journeys, traces of the ploughshare were discoverable; but the total ignorance of the primitive nations of America with regard to this agricultural implement, the want of draft cattle, and the great extent of ground over which the supposed furrows are found,-all lead me to conjecture that this singular appearance of a ploughed field has been produced by some effect of water on the surface of the earth.

$$
\text { (13) p. 7.— "Like an arm of the Sea." }
$$

The great Steppe, which extends from east to west from 
the mouth of the Orinoe to the snowy mountains of Merida, turns to the south in the 8th degree of latitude, filling the space between the eastern declivity of the high mountains of New Granada, and the Orinoco, the course of which is, in this part, from south to north. This latter portion of the Llanos, which is watered by the Meta, the Vichada, the Zama, and the Guaviare, connects the valley of the Amazons with the valley of the Lower Orinoco. The word Paramo, which I often employ in these pages, signifies in Spanish America all those mountainous regions which are elevated from 1800 to 2200 toises above the level of the sea (11500 to 14000 English feet in round numbers), and in which an ungenial, rough, and misty climate prevails. Hail and snow fall daily for several hours in the upper Paramos, and furnish a beneficial supply of moisture to the alpine plants; a supply not arising from a large absolute quantity of aqueous vapour in these high regions, but from the frequency of showers, (hail and snow being so termed as well as rain), produced by the rapidly changing currents of air, and the variations of the electric tension. The arborescent vegetation of these regions is low and spreading, consisting chiefly of large flowering laurels and myrtle-leaved alpine shrubs, whose knotty branches are adorned with fresh and evergreen foliage. Escallonia tubai, Escallonia myrtilloides, Chuquiragua insignis, Aralias, Weinmannias, Frezieras, Gualtherias, and Andromeda reticulata, may be regarded as representatives of the physiognomy of this vegetation. To the south of the town of Santa Fe de Bogota is the Paramo de la Suma Paz; a lonely mountain 
group, in which, according to Indian tradition, vast treasures are buried. The torrent which flows under the remarkable natural bridge of the rocky ravine of Icononzo rises in this Paramo. In my Latin memoir entitled “De distributione geographica Plantarum secundem cœli temperiem et altitudinem montium, 1817," I have sought to characterise those mountain regions: "Altitudine 1700-1900 hexapod. Asperrimæ solitudines, quæ a colonis hispanis uno nomine Paramos appellantur, tempestatum vicissitudinibus mire obnoxiæ, ad quas solutæ et emollitæ defluunt nives; ventorum flatibus ac nimborum grandinisque jactu tumultuosa regio, quæ æque per diem et per noctes riget, solis nubila et tristi luce fere nunquam calefacta. Habitantur in hac ipsa altitudine sat magnæ civitates, ut Micuipampa Peruvianorum, ubi thermometrum centes. meridie inter $5^{\circ}$ et $8^{\circ}$, noctu $-0^{\circ} .4$ consistere vidi; Huancavelica, propter cinnabaris venas celebrata, ubi altitudine 1835 hexap. fere totum per annum temperies mensis Martii Parisiis." (Humboldt de distrib. geogr. Plant, p. 104.)

(14) p. 8.- "The Andes and the eastern mountains send forth detached spurs which advance towards each other."

The vast region situated between the eastern coast of South America and the eastern declivity of the Andes is narrowed by two mountain masses, which partially divide from each other the three valleys or plains of the Lower Orinoco, of the Amazons, and of the River Plate. The 
most northern mountains, called the group of the Parime, are opposite to the Andes of Cundinamarca which projest far to the east, and assume in the 66th and 68th degrees of longitude the form of high mountains, connected by the narrow ridge of Pacaraima with the granite hills of French Guians. On the map of Columbia constructed by me from my own astronomical observations, this connection is clearly marked. The Caribs, who penetrated from the missions of the Caroni to the plains of the Rio Branco, and as far as the Brazilian boundary, crossed in the journey the ridges of Pacaraima and Quimiropaca. The second mountain mass, which divides the valley of the Amazons from the River Plate, is the Brazilian group. In the province of Chiquitos (west of the Parecis range of hills), it approaches the promontory of Santa Cruz de la Sierra. As neither the group of the Parime which causes the great cataracts of the Orinoco, nor the Brazilian group of mountains, are absolutely connected with the Andes, the plains of Venezuela have a direct connection with those of Patagonia. (See my geognostical view of South America, in Relat. Hist. T. iii. p. 188-244.)

$$
\text { (15) p. 8.- "Troops of dogs." }
$$

European dogs have become wild in the grassy plains or Pampas of Buenos Ayres. They live in society, and in hollows in which they hide their young. If the society becomes too numerous, some families detach themselves and form new colonies. The European dog, which has become wild, barks as loud as the original American hairy race. 
Garcilaso relates, that before the arrival of the Spaniards the Peruvians had dogs, "perros gozques." He calls the native dog, Allco: it is called at present in the Quichua language, to distinguish him from the European dog, "Runa-allco," "Indian dog" (dog of the inhabitants of the country). The hairy Runa-allco seems to be a mere variety of the shepherd's dog. He is small, with long hair, (usually of an ochry yellow, with white and brown spots,) and with upright sharp-pointed ears. He barks a great deal, but seldom bites the natives, however disposed to be mischievous to the whites. When the Inca Pachacutec, in his religious wars with the Indians of Xauxa and Huanca (the present valley of Huancaya and Jauja), conquered them, and converted them forcibly to the worship of the sun, he found them paying divine honours to dogs. Priests blew on the skulls of dogs, and the worshippers ate their flesh. (Garcilaso de la Vega, Commentarios Reales, P. i. p. 184.) This veneration of dogs in the valley of Huancaya is probably the reason why skulls and even entire mummies of dogs have been found in the Huacas, or Peruvian graves belonging to the earliest epoch. Von Tschudi, the author of an excellent Fauna Peruviana, has examined these skulls, and believes them to belong to a peculiar species of dog which he cali. Canis ingæ, and which is different from the European doo. The Huancas are still called derisively by the inhabitants of other provinces, "dogeaters." Among the natives of the Rocky Mountains, cooked dog's flesh is set before strangers as a feast of honour. Near Fort Laramie, (one of the stations of the Hudson's 
Bay Company for the fur trade with the Sioux Indians), Captain Frémont attended a feast of this description. (Frémont's Exploring Expedition, 1845, p. 42.)

The Peruvian dogs had a singular part to play in eclipses of the moon: they were beaten until the eclipse was over. The Mexican Techichi, a variety of the common dog, which latter was called in Anahuac Chichi, was completely dumb. Techichi signifies literally stone-dog, from the Aztec, Tetl, a stone. The Techichi was eaten according to the old Chinese fashion. The Spaniards found this food, before the introduction of European cattle, so indispensable, that almost the whole race was gradually extirpated. (Clavigero, Storia antica del Messico, 1780, T. i. p. 73.) Buffon confounds the Techichi with the Koupara of Guiana. (T. xv. p. 155.) The latter is identical with the Procyon or Ursus cancrivorus, the Raton crabier, or crab-eating Aquaraguaza of the Patagonian coast. (Azara sur les quadrupèdes du Paraguay, T. i. p. 315.) Linnæus, on the other hand, confounds the dumb variety of dogs with the Mexican Itzcuintepotzotli, a kind of dog still only imperfectly described, said to be distinguished by a short tail, a very small head, and a large hump on the back. The name signifies humped-dog, and is formed from the Aztec, itzcuintli (another word for dog), and tepotzotli, humped, a humpback. I was particularly struck in America, and especially in Quito and generally in Peru, with the great number of black dogs without hair, called by Buffon "chiens tures" (Canis ægyptius, Linn.) Even among the Indians this variety is common, but it is generally despised 
and ill-treated. All European breeds of dogs perpetuate themselves very well in South America, and if the dogs there are not so handsome as those in Europe, the reason is partly want of care, and partly that the handsomest varieties (such as fine greyhounds and the Danish spotted breed) have never been introduced there.

Herr von Tschudi makes the singular remark, that in the Cordilleras, at elevations of 13000 feet, tender races of dogs and the European domestic cat are exposed to a particular kind of mortal disease. "Innumerable attempts have been made to keep cats as domestic animals in the town of the Cerro de Pasco, 13228 French (or 14100 English) feet above the level of the sea, but such attempts have failed, both cats and dogs dying at the end of a few days in fits, in which the cats were taken at first with convulsive movements, then tried to climb the walls, fell back 'exhausted and motionless, and died. In Yauli I had several opportunities of observing this chorea-like disease; it seems to be a consequence of the absence of sufficient atmospneric pressure." In the Spanish colonies, the hairless dog was looked upon as of Chinese origin, and called Perro Chinesco, or Chino. The race was supposed to have come from Canton or from Manila: according to Klaproth, it has certainly been extremely common in China since very early times. Among the animals indigenous to Mexico there was an entirely hairless, dog-like, but very large wolf, called Xoloitzcuintli (from the Mexican xolo or xolotl, servant or slave). On American dogs, see Smith Barton's Fragments of the Natural History of Pennsylvania, P.i. p. 34. 
The result of Tschudi's researches on the American indigenous races of dogs is the following. There are two kinds almost epecifically different: 1 . The Canis caraibicus of Lesson, quite without hair, except a small bunch of white hair on the forehead and at the point of the tail, of a slate grey colour, and silent; it was found by Columbus in the Antilles, by Cortes in Mexico, and by Pizarro in Peru, where it suffers from the cold of the Cordilleras, but is still abundant in the warmer parts of the country, under the name of perros chinos. 2. The Canis ingæ, with pointed nose and pointed ears ; this kind barks : it is now employed in the care of cattle, and shews many varieties of colours, from being crossed with European breeds. The Canis ingæ follows man to the high regions of the Cordilleras. In ancient Peruvian graves his skeleton is sometimes found resting at the feet of the human mummy. We know how often the carvers of monuments in our own middle ages employed the figure of a dog in this position, as an emblem of fidelity. (J. J. v. Tschudi, Untersuchungen über die Fauna Peruana, S. 247-251.) At the very beginning of the Spanish conquests European dogs became wild in the islands of San Domingo and Cuba. (Garcilaso, P. i. 1723, p. 326.) In the prairies between the Meta, the Arauea, and the Apure, voiceless dogs, (perros mudos,) were eaten in the 16th century. Alonso de Herrara, who, in 1535, undertook an expedition to the Orinoco, says the natives called them "Majos" or "Auries." A well-informed traveller, Giesecke, found the same non-barking variety of dog in Greenland. The Esquimaux dogs pass their lives entirely 
in the open air ; at night they scrape holes for themselves in the snow; they howl like wolves, in accompaniment with a dog that sits in the middle of the circle and sets them off. In Mexico the dogs were subjected to an operation to make them fatter and better eating. On the borders of the province of Durango, and farther to the north on the slave lake, the natives, furmerly at least, conveyed their tents of buffalo skins on the backs of large dogs when changing their place of residence with the change of season. All these traits resemble the customs of the inhabitants of eastern Asia. (Humboldt, Essai polit. T. ii. p. 448; Relation hist. T. ii. p. 625.)

$\left.{ }^{16}\right)$ p. 8. - "Like the greater part of the Desert of Sahara, the Llanos are in the torrid zone."

Significant denominations,-particularly such as refer to the form in relief of the earth's surface, and which have arisen at a period when there was only very uncertain information respecting the countries in question and their hypsometric relations,- - have led to various and longcontinued geographical errors. The ancient denomination of the "Greater and Lesser Atlas" (Ptol. Geogr. lib. iii. cap. 1) has exercised the prejudicial influence here alluded to. No doubt the snow-covered western summits of the Atlas in the territory of Morocco may be regarded as the Great Atlas of Ptolemy ; but where is the limit of the Little Atlas? Is the division into two Atlas chains, which the conservative tendencies of geographers have preserved for 1700 years, to be still maintained in the territory of Algiers, and even between Tunis and Tlemse? Are we to seek between the 
coast and the interior for parallel chains constituting a greater and a lesser Atlas? All travellers familiar with geognostical views, who have visited Algeria since it has been taken possession of by the French, contest the meaning conveyed by the generally received nomenclature. Among the parallel chains, that of Jurjura is generally supposed to be the highest of those which have been measured; but the well-informed Fournel, (long Ingenieur en chef des Mines de l'Algérie), affirms that the mountains of Aurès, near Batnah, which were still found covered with snow at the end of March, are higher. Fournel denies the existence of a Little and a Great Atlas, as I do that of a Little and a Great Altai (Asie Centrale, T. i. p. 247-252). There is only one Atlas, formerly called Dyris by the Mauritanians, and "this name is to be applied to the "foldings," ("rides") or succession of crests which form the division between the waters flowing to the Mediterranean, and those which flow towards the Sahara lowland. The strike or direction of the Eastern Mauritanian portion of the Atlas is from east to west; that of the elevated Atlas of Morocco from north-east to south-west. The latter rises into summits which, according to Renou, (Exploration Scientifique de l'Algérie de 1840 à 1842, publiée par ordre du Gouvernement, Sciences Hist. et Geogr. T. viii. 1846, p. 364 and 373), attain an elevation of 10,700 Fr. (11400 Eng.) feet; exceeding, therefore, the height of Etna. A singularly formed highland of an almost square shape, (Sahab el Marga), bounded on the south by higher elevations, is situated in $33^{\circ}$ lat. From thence towards the sea to VOL. I. 
the west, about a degree south of Mogador, the Atlas declines in height: this south-westernmost part bears the name of Idrar-N-Deren.

The northern Mauritanian boundaries of the widely extended low region of the Sahara, as well as its southern limits towards the fertile Soudan, are still but little known. If we take on a mean estimation the parallels of $16 \frac{1}{2}^{\circ}$ and $32 \frac{1}{2}^{\circ}$ as the outside limits, we obtain for the Desert, including its Oases, an area of more than 118500 square German geographical miles; or between nine and ten times the area of Germany, and almost three times that of the Mediterranean exclusive of the Black Sea. From the best and most recent intelligence, for which we are indebted to the French Colonel Daumas and MM. Fournel, Renou, and Carette, we learn that the desert of Sahara is composed of several detached basins, and that the number and the population of the fertile Oases is very much greater than had been imagined from the awfully desert character of the route between Insalah and Timbuctoo, and that from Mourzouk in Ferzan, to Bilma, Tirtuma, and Lake Tschad. It is now generally affirmed that the sand covers only the smaller portion of the great lowland. A similar opinion had been previously propounded by the acutely observant Ehrenberg, my Siberian travelling companion, from what he had himself seen (Exploration Scientifique de l'Algérie, Hist. et Geogr. T. ii. p. 332). Of larger wild animals, only gazelles, wild asses, and ostriches are to be met with. "Le lion du désert," says M. Carette, (Explor. de l'Alg. T. ii. p. 126-129; T. vii. p. 94 and 97), "est un mythe popularisé par les artistes et les poètes. Il 
n'existe que dans leur imagination. Cet animal ne sort pas de sa montagne où il trouve de quoi se loger, s'abreuver et se nourrir. Quand on parle aux habitans du désert de ces bêtes féroces que les Européens leur donnent pour compagnons, ils repondent avec un imperturbable sang froid, il y a done chez vous des lions qui boivent de l'air et broutent des feuilles? Chez nous il faut aux lions de l'eau courante et de la chair vive. Aussi des lions ne paraissent dans le Zahara que là où il y a des collines boisées et de l'eau. Nous ne craignons que la vipère (lefa) et d'innombrables essaims de moustiques, ces derniers là où il y a quelque humidité."

Whereas Dr. Oudney, in the course of the long journey from Tripoli to Lake Tschad, estimated the elevation of the southern Sahara at 1637 English feet, to which German gengraphers have even ventured to add an additional thousand feet, the Ingenieur Fournel has, by careful barometric measurements based on corresponding observations, made it tolerably probable that a part of the northern desert is below the level of the sea. That portion of the desert which is now called "le Zahara d'Algérie" advances to the chains of hills of Metlili and el-Gaous, where the northernmost of all the Oases, - that of el-Kantara, fruitful in dates, -is situated. This low basin, which touches the parallel of $34^{\circ}$ lat., receives the radiant heat of a stratum of chalk, (full of the shells of Inoceramus), inclined at an angle of $65^{\circ}$ towards the south (Fournel sur les Gisemens de Muriate de Soude en Algérie, p. 6 in the Annales des Mines, 4me Série, T. ix., 1846, p. 546). "Arrivés a Biscara," (Biskra), says Fournel, "un horizon indéfini 
comme celui de la mer se déroulait devant nous." Between Biscara and Sidi Ocba the ground is only 228 (243 Eng.) feet above the level of the sea. The inclination increases considerably towards the south. In another work, (Asie Centrale, T. ii. p. 320), where I have brought together everything relating to the depression of some portions of continents below the level of the sea, I have already noticed that according to Le Père the "bitter lakes" on the isthmus of Suez, when they have a little water,-and, according to General Andréossy, the Natron lakes of Fayoum,-are also lower than the level of the Mediterranean.

Among other manuscript notices of M. Fournel, I possess a vertical geological profile, which gives all the inflexions and inclinations of the strata, representing a section of the surface the whole way from Philippeville on the coast to the Desert of Sahara, at a spot not far from the Oasis of Biscara. The direction of the line on which the barometric measurements were taken is south $20^{\circ}$ west; but the elevations determined are projected, as in my Mexican profiles, on a different plane,-a north-south one. Ascending uninterruptedly from Constantine, at an elevation of 332 toises (2122 Eng. feet), the culminating point is found between Batnah and Tizur, at an elevation of only 560 oises (3580 Eng. feet). In the part of the desert situated between Biscara and Tuggurt, Fournel has had a series of Artesian wells dug with success (Comptes Rendus de l'Acad. des Sciences, t. xx. 1845, p. 170, 882, and 1305). We learn from the old accounts of Shaw, that the inhabitants of the country knew of a subterranean supply of water, and 
relate fabulous tales of a "sea under the earth (bahr tôht el-erd)." Fresh waters flowing between clay and marl strata of the old cretaceous and other sedimentary deposits, under the action of hydrostatic pressure form gushing fountains when the strata are pierced (Shaw, Voyages dans plusieurs parties de la Berbérie, t. i. p. 169 ; Rennell, Africa, Append. p. Ixxxv). That fresh water in this part of the world should often be found near beds of rock salt, need not surprise geologists acquainted with mines, since Europe offers many analogous phenomena.

The riches of the desert in rock-salt, and the fact of rock-salt having been used in building, have been known since the time of Herodotus. The salt zone of the Sahara (zone salifère du désert), is the southernmost of three zones; stretching across Northern Africa from south-west to northeast, and believed to be connected with the beds or deposits of rock-salt of Sicily and Palestine, described by Friedrich Hoffman and by Robinson. (Fournel, sur les Gisements de Muriate de Soude en Algérie, p. 28-41; Karsten über das Vorkommen des Kochsalzes auf der Oberfläche der Erde, 1846, S. 497, 648, and 741.) The trade in salt with Soudan, and the possibility of cultivating dates in the Oases, formed by depressions caused probably by falls or subsidences of the earth in the gypsum beds of the tertiary cretaceous or keuper promotions, have alike contributed to enliven the Desert, at least to some extent, by human intercourse. The high temperature of the air, which makes the day's march so oppressive, renders the coldness of the nights, (of which Denham complained so often in the African Desert, and Sir Alexander Burnes in the Asiatic), 
so much the more striking. Melloni, (Memoria sull' abassamento di temperatura durante le notti placide e serene, 1847, p. 55), ascribes this cold, produced doubtless by the radiation from the ground, less to the great purity and serenity of the sky, (irrigiamento calorifico per la grande serenità di cielo nell' immensa e deserta pianura dell' Africa centrale), than to the profound calm, the nightly absence of all movement in the atmosphere. (Consult also, respecting African meteorology, Aimé in the Exploration de l'Algérie, Physique génerale, T. ii., 1846, p. 147.)

The southern declivity of the Atlas of Morocco sends to the Sahara, in lat. $32^{\circ}$, a river, the Quad-Dra (Wady-Dra), which for the greater part of the year is nearly dry, and which Renou (Explor. de l'Alg. Hist. et Geogr., T. viii. p. 65-78) considers to be a sixth longer than the Rhine. It flows at first from north to south, until, in lat. $29^{\circ} \mathrm{N}$. and long. $5^{\circ} \mathrm{W}$., it turns almost at right angles to its former course, runs to the west, and, after passing through the great fresh water Lake of Debaid, enters the sea at Cape Nun, in lat. $28^{\circ} 46^{\prime} \mathrm{N}$. and long. $11^{\circ} 08^{\prime} \mathrm{W}$. This region, which was so celebrated formerly in the history of the Portuguese discoveries of the 15th century, and was afterwards wrapped in profound geographical obscurity, is now called on the coast "the country of the Sheikh Beirouk," (a chief independent of the Emperor of Morocco.) It was explored in the months of July and August 1840, by Captain Count Bouet-Villaumez of the French Navy, by order of his government. From the official Reports and Surveys which have been communicated to me in manuscript, it appears evident that the mouth of the 
Quad.Dra is at present very much stopped up with sand, having an open channel of only about 190 English feet wide. A somewhat more easterly channel in the same mouth is that of the still very little known Saguiel el-Hamra, which comes from the south, and is supposed to have a course of at least 600 geographical miles. One is astonished at the length of these deep, but commonly dry river beds. They are ancient furrows, such as I have seen in the Peruvian desert at the foot of the Cordilleras, between those mountains and the coast of the Pacific. In Bouet's manuscript "Relation de l'Expédition de la Malouine," the mountains which rise to the north of Cape Nun are estimated at the great elevation of 2800 metres (9185 English feet).

Cape Nun is usually supposed to have been discovered in 1433, by the Knight Gilianez, acting under the command of the celebrated Infante Henry Duke of Viseo, and founder of the Academy of Sagres, which was presided over by the pilot and cosmographer Mestre Jacomè of Majorca; but the Portulano Mediceo, the work of a Genoese Navigator in 1351, already contains the name of Cavo di Non. The passage round this Cape was then as much dreaded as that of Cape Horn has since been, although it is 23' north of the parallel of Teneriffe, and could be reached in a few days' voyage from Cadiz. The Portuguese proverb, " quem passa o Cabo di Num, ou tornarà ou nāo," could not deter the Infante, whose heraldic French motto, "talent de bien faire," expressed his noble, enterprising, and vigorous character. The name of the Cape, in which a play of words on the negative particle has long been supposed, does not appear to me to have had a Portuguese origin. Ptolemy 
placed on the north-west coast of Africa a river Nuius, in the Latin version Nunii Ostia. Edrisi speaks of a town, Nul, or Wadi Nun, somewhat more to the south, and three days' journey in the interior: Leo Africanus calls it Belad de Non. Long before the Portuguese squadron of Gilianez, other European navigators had advanced much bcyond, or to the southward of, this Cape. The Catalan, Don Jayme Ferrer, in 1346, as we learn from the Atlas Catalan published by Buchon at Paris, had advanced as far as the Gold River, (Rio do Ouro), in lat. $23^{\circ} 56^{\prime}$; and Normans, at the end of the 14th century, as $f_{a r}$ as Sierra Leone in lat. $8^{\circ} 30^{\prime}$. The merit of having been the first to cross the equator on the western coast of Africa belongs, however, like that of so many other memorable achievements, to the Portuguese.

(17) p. 8.- "As a grassy plain, resembling many of the Steppes of Central Asia."

The Llanos of Caraccas and of the Rio Apure and the Meta, over which roam large herds of cattle, are, in the striclest sense of the term, "grassy plains." Their prevalent vegetation, belonging to the two families of Cyperaceæ and Gramineæ, consists of various species of Paspalum, P. leptostachyum and P. lenticulare; of Kyllingia, K. monocephala (Rottb.), K. odorata ; of Panicum, P. granuliferum, P. micranthum; of Antephora; Aristida; Vilfa; and Anthistiria, A. reflexa, and A. foliosa. Only here and there are found, interspersed among the Gramineæ, a few herbaceous dicotyledonous plants, consisting of two very low-growing species of Mimosa, (Sensitive Plant), Mimosa 
intermedia, and Mimosa dormiens, which are great favourites with the wild horses and cattle. The natives give to this group of plants, which close their delicate feathery leaves on being touched, the expressive name of Dormiderassleepy plants. For many square miles not a tree is seen; but where solitary trees are found, they are, in moist places, the Mauritia Palm; in arid districts, a Proteacea, described by Bonpland and myself, the Rhopala complicata (Chaparro bobo), which Wildenow, regarded as an Embothrium; also the highly useful Palma de Covija, or de Sombrero; and our Corypha inermis, an umbrella palm allied to Chamærops, which is used to cover the roofs of huts. How far more varied is the aspect of the Asiatic plains! Throughout a large portion of the Kirghis and Calmuck Steppes, which I have traversed from the Don, the Caspian, and the Orenburg Ural river the Jaik, to the Obi and the Upper Irtysh near Lake Dsaisang, through a space of 40 degrees of longitude, I have never seen, as in the Llanos, the Pampas, and the Prairies, an horizon like that of the ocean, where the vault of heaven appears to rest on the unbroken plain. At the utmost this appearance presented itself in one direction, or towards one quarter of the heavens. The Asiatic Steppes are often crossed by ranges of hills, or clothed with coniferous woods or forests. Even in the most fruitful pastures the vegetation is by no means limited to grasses ; there is a great variety of herbaceous plants and shrubs. In spring-time small snow-white and red-flowering rosaceæ and amygdaleæ (Spiræa, Cratægus, Prunus spinosa, and Amygdalus nana) present a smiling aspect. I have already mentioned the tall and luxuriant 
Synantheræ (Saussurea amara, S. salsa, Artemisias, and Centaureas), and of leguminous plants, species of Astragalus, Cytisus, and Caragana. Crown Imperials, (Fritillaria ruthenica, and F. meleagroides), Cypripedias, and tulips, rejoice the eye by the bright variety of their colours.

A contrast to the pleasing vegetation of these Asiatic plains is presented by the desolate salt Steppes, particularly by the part of the Barabinski Steppe which is at the foot of the Altai mountains, and by the Steppes between Barnaul and the Serpent Mountain and the country on the east of the Caspian. Here Chenopodias, some species of Salsola and Atriplex, Salicornias and Halimocnemis crassifolia, (each species growing "socially"), form patches of vegetation on the muddy ground. See Göbel's Journey in the Steppes of the South of Russia (Reise in die Steppe des südlichen Russlands, 1838, Th. ii. S. 244 and 301). Of the 500 phanerogamous species which Claus and Göbel collected in the Steppes, the Syrantheræ, the Chenopodeæ, and the Cruciferæ, were more numerous than the grasses; the latter being only $\frac{1}{11}$ of the whole, and the former $\frac{1}{7}$ th and $\frac{1}{9}$ th. In Germany, from the mixture of hill and plain districts, the Glumacex (i.e. the Gramineæ, Cyperaceæ, and Juncaceæ collectively), form $\frac{1}{7}$ th ; the Synantheræ or Compositæ $\frac{1}{8}$ th ; and the Cruciferæ $\frac{1}{18}$ th of all our German phanerogamia. In the most northern parts of the flat Siberian lowlands, the fine map of Admiral Wrangell shews that the extreme northern limit of tree and shrub vegetation (Coniferæ and Amentaceæ) is, in the portion towards the Behring's Straits side, in $67 \frac{1}{4}^{\circ}$ lat.; and more to the west, towards the banks of the Lena, in $71^{\circ}$, which is the parallel of the north cape of Lapland. 
The plains which border the Icy Sea are the domain of cryptogamous plants. They are called Tundras (Tuntur in Finnish) : they are swampy districts extending farther than the eye can reach, partly covered with a thick carpet of Sphagnum palustre and other mosses, and partly with a dry snow-white covering of Cenomyce rangiferina (Rein-deer moss), Stereocaulon paschale, and other lichens. Admiral Wrangell, in describing his perilous expedition to the new Siberian islands so rich in fossil wood, says: "These Tundras accompanied me to the extreme arctic coast. Their soil has been frozen for thousands of years. In the dreary uniformity of landscape, the eye of the traveller, surrounded by rein-deer moss, dwells with pleasure on the smallest patch of green turf showing itself now and then on a moist spot."

${ }^{18}$ p. 8.- "The causes which lessen both heat and dryness in the New World."

I have tried to bring together in a brief and compendious manner the various causes which produce greater moisture and a less degree of heat in America ; it will of course be understood that the question respects the general hygrometric state of the atmosphere, and the temperature of the New Continent as a whole. Single districts, such as the island of Margarita, the Coasts of Cumana and Coro, are as hot and as dry as any part of Africa. It must also be remarked that the maximum of heat at certain hours of a summer's day has been found, on a series of years, to be almost equal at very different parts of the earth's surface, on the Neva, the Senegal, the Ganges, and the Orinoco; being approximately between 
$97^{\circ}$ and $32^{\circ}$ Reaumur $\left(93^{\circ}\right.$ and $104^{\circ}$ Fahrenheit), and generally not higher,- - providing the observation be made in the shade, at a distance from all solid bodies which could radiate heat. to the thermometer, not in an air filled with hot particles of dust or sand, and not with spirit thermometers, which absorb the light. It is probably to fine grains of sand floating in the air, and forming centres of radiant heat, that we must ascribe the dreadful temperature of $40^{\circ}$ to $44^{\circ} .8$ Reaumur (122 $2^{\circ}$ to $133^{\circ}$ Fah.) in the shade, to which my unhappy friend Ritchie, who perished there, and Captain Lyon, were exposed for weeks in the Oasis of Mourzouk. The most remarkable instance of very high temperature, in an air probably free from dust, has been recorded by an observer who knew well how to place and to correct all his instruments with the greatest degree of accuracy. Rüppell found $37^{\circ} .6$ Reaumur, (110 .6 Fahrenheit,) at Ambukol in Abyssinia, with a clouded sky, strong south-west wind, and an approaching thunderstorm. The mean annual temperature of the tropics, or of the proper climate of palms, is, on land, between $20^{\circ} .5$ and $23^{\circ} .8$ Reaumur (or $78^{\circ} .2$ and $85^{\circ} .5$ Fahrenheit) without any considerable difference between the observations collected in Senegal, Pondichery, and Surinam. (Humboldt, Mémoire sur les lignes isothermes, 1817, p. 54. Asie Centrale, T. iii. Mahlmann, Table iv.)

The great coolness, I might almost say cold, which prevails for a considerable part of the year within the tropics on the coast of Peru, causing the thermometer to sink to $12^{\circ}$ Reaumur (59 $9^{\circ}$ Fahrenheit), is, as I have noticed elsewhere, by no means to be ascribed to the vicinity of the snow- 
covered Andes, but rather to the fogs (garua) which veil the solar disk, and to a cold sea current which, commencing in the antarctic regions and coming from the south-west, strikes the coast of Chili near Valdivia and Conçeption, and thence streams rapidly along the coast to the northward, as far as Cape Parina. On the coast, near Lima, the temperature of the Pacific is $12^{\circ} .5$ Reaumur $\left(60^{\circ} .2\right.$ Fahr.), whilst in the same latitude out of the current it is $21^{\circ} \mathrm{R}$. $\left(79^{\circ} .2\right.$ Fahr.) It is singular that so striking a fact should have remained unnoticed until my visit to the shores of the Pacific, in October 1802.

The variations of temperature of different regions depend in a great degree on the character of the bottom of the "aerial ocean," or on the nature of the floor or base, whether land or sea, continental or oceanic, on which the atmosphere rests. Seas, often traversed by currents of warmer or colder water, (oceanic rivers), have an effect very different from that of continental masses, whether unbroken or articulated, or of islands, which latter may be regarded as shallows in the aerial ocean, and which, notwithstanding their small dimensions, exert, oiten to a great distance, a notable influence on the climate of the sea. In continental masses we must distinguish between sandy deserts devoid of vegetation, savannahs or grassy plains, and forest-covered districts. In Upper Egypt and in South America, Nouet in the former, and myself in the latter, found respectively at noon the temperature of the ground composed of granitic sand $54^{\circ} .2$ and $48^{\circ} .4$ Reaumur ( $154^{\circ}$ and $141^{\circ}$ Fahr.) Many careful observations in Paris have given, according to Arago, $40^{\circ}$ and $42^{\circ}$ Reaumur, $122^{\circ}$ and $126^{\circ} .5$ Falirenheit. (Asie 
Centrale, T. iii. p. 176.) The Savannahs, which between the Missouri and the Mississipi are called Prairies, and which appear in South America as the Llanos of Venezuela and the Pampas of Buenos Ayres, are corered with small monocotyledonous plants of the family of Cyperaceæ, and with grasses of which the thin pointed stalks or ears, and the delicate lanceolate leaves or blades, radiate towards the unclouded sky, and possess an extraordinary power of " emission." Wells and Daniell (Meteor. Essays, 1827, p. 230 and 278) have even seen in our latitude, where the atmosphere has so much less transparency, the thermometer sink $6^{\circ} .5$ or $8^{\circ}$ of Reaumur $\left(14^{\circ} .5\right.$ or $18^{\circ}$ Fahrenheit), on being placed on the grass. Melloni, in a memoir, "Sull abassamento di temperatura durante le notti placide e serene," 1847, p. 47 and 53, has shewn how in a calm state of the atmosphere, which is a necessary condition of strong radiation and of the formation of dew, the cooling of the grassy surface is also promoted by the particles of air which are already cooled sinking to the ground as being the heaviest. In the vicinity of the equator, under the clouded sky of the Upper Orinoco, the Rio Negro, and the Amazons River, the plains are clothed with dense primeval forests ; but to the north and south of this wooded region there extend from the zone of palms and lofty dicotyledonous trees, in the northern hemisphere, the Llanos of the Lower Orinoco the Meta and the Guaviare, and in the southern hemisphere the Pampas of the Rio de la Plata and of Patagonia. The space thus occupied by Savannahs or grassy plains in South America is at least nine times as great as the area of France. The wooded region acts in a threefold manner in diminish- 
ing the temperature. by cooling shade, by evaporation, and by radiation. Forests, - which in our temperate zone consist of trees living together in "society," $i$. e., many individuals of one, or of a few kinds, of the families of Coniferæ or Amentaceæ, oaks, beeches, and birches, but in the tropics, of an immense variety of trees living separately or " unsocially,"-protect the ground from the direct rays of the sun, evaporate fluids elaborated by the trees themselves, and cool the strata of air in immediate contact with them by the radiation of heat from their appendicular organs or leaves. The latter are far from being all parallel with each other; they are, on the contrary, variously inclined to the horizon, and, according to the law developed by Leslie and Fourier, the influence of this inclination upon the quantity of heat emitted by radiation is such, that the power of radiation (pouvoir rayonnant) of a measured surface $a$, having a given oblique direction, is equal to the "pouvoir rayonnant" which would belong to a surface of the size of $a$, projected on a horizontal plane. Now in the initial condition of radiation, of all the leaves which form the summit of a tree and partly cover each other, those are first cooled which are directed without any intervening screen towards the unclouded sky. The cooling result (or the exhaustion of heat by emission) will be the more considerable the greater the thinness of the leaves. A second stratum of leaves has its upper surface turned to the under surface of the first stratum, and will give out more heat by radiation towards that stratum than it can receive by radiation from it. The result of this unequal exchange will thus be a loss of temperature for the second stratum 
of leaves also A similar operation will continue from stratum to stratum until all the leaves of the tree, by greater or less radiation as modified by their diversity of position, have passed into a state of stable equilibrium of which the law can be deduced by mathematical analysis. In this manner, in the long and clear nights of the equinoctial zone, the forest air contained in the intervals between the strata of leaves becomes cooled by the process of radiation; and by reason of the great quantity of its thin appendicular organs or-leaves, a tree, the horizontal section of whose summit would measure for example 2000 square feet, would act in diminishing the temperature of the air equivalently to a space of bare or turf-covered ground several thousand times greater than 2000 square feet (Asie Centrale, T. iii. p. 195-205). I have sought thus to develope in detail the comp'icated effects which make up the total action of extensive forests upon the atmosphere, because they have been so often touched upon in reference to the important question concerning the climates of ancient Germany and Gaul.

As in the old continent European civilization has had its principal seats on a western coast, it could not but be early remarked that, under equal degrees of latitude, the opposite eastern coast of the United States was several degrees colder in mean annual temperature than Europe, which is, as it were, a projecting western peninsula to Asia, as Brittany is to the rest of France. But in this remark it was forgotten that these differences decrease from the higher to the lower latitudes in such manner that they s. Imost entirely disappear from $30^{\circ}$ downwards. For the 
west coast of the new continent, exact thermometric observations are still almost entirely wanting; but the mildness of the winters in New California shews that the west coasts of America and Europe, under the same parallels of latitude, probably differ little from each other in mean annual temperature. The subjoined table shows what are the corresponding mean annual temperatures, in the same geographical latitudes, of the west coast of Europe and the east coast of the New Continent.

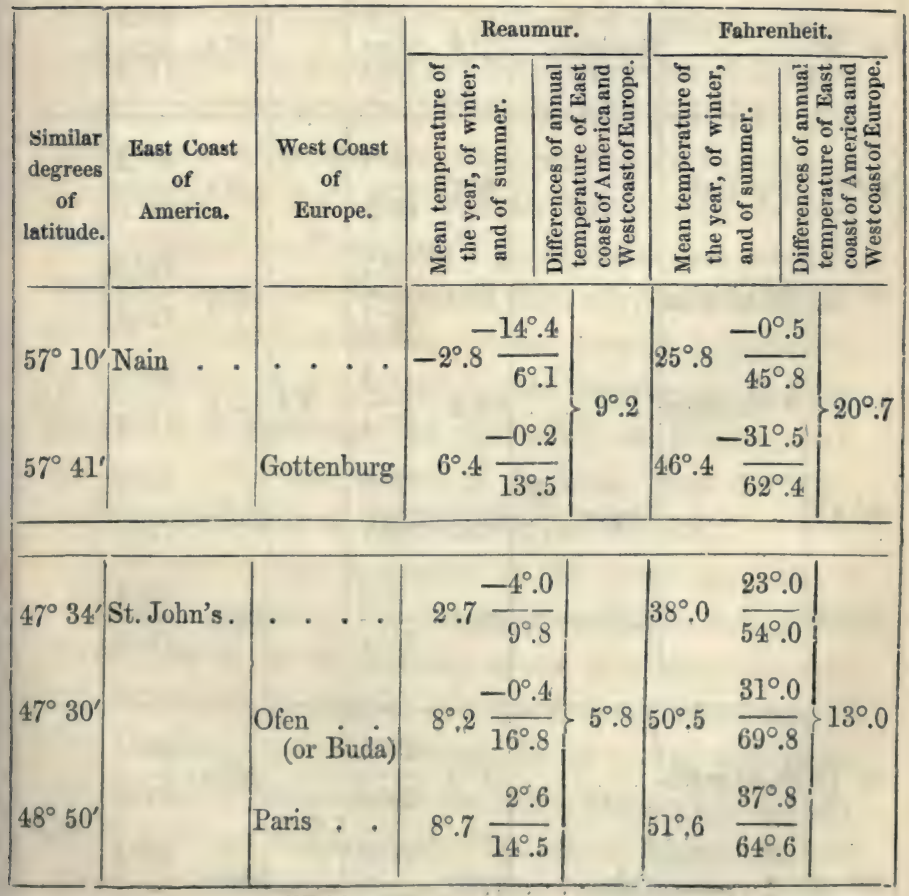

VOL. I. 


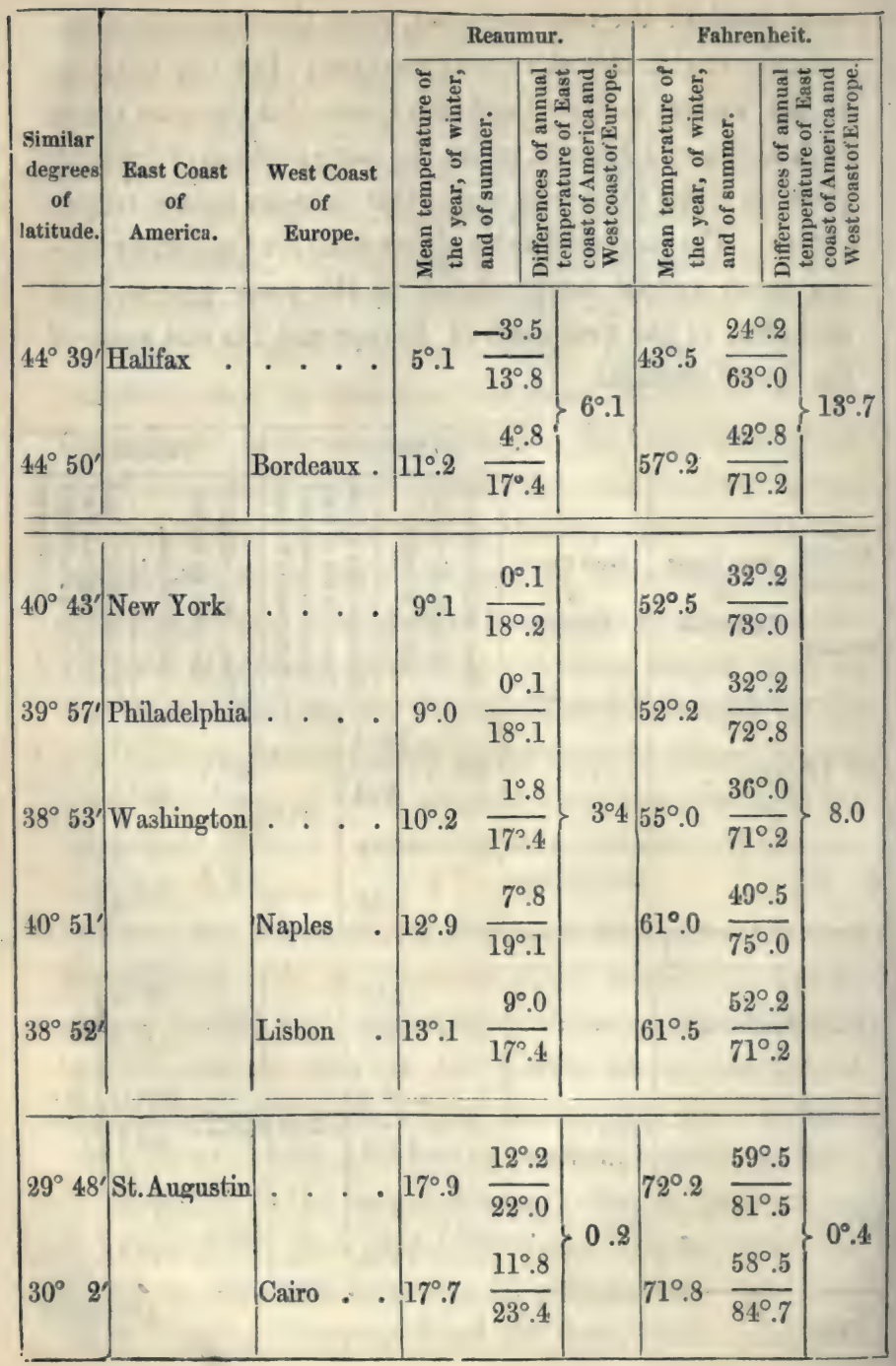


In the column of temperatures in the preceding table the frrst number represents the temperature of the year; that which stands in place of a numerator the mean winter ternperature; and that which stands in the place of a denominator the mean summer temperature. Besides the great difference of mean annual temperature, there is also a striking difference between the two coasts in respect to the distribution of that temperature into the different seasons of the year, and it is this distribution which is most influential both on our feelings and on the processes of vegetation. Dove remarks generally, that the summer temperature of America is lower under equal degrees of latitude than that of Europe: (Temperatur tafeln nebst Bemerkungen über die Verbreitung der Wärme auf der Oberfläche der Erde, 1848, S. 95.) The climate of St. Petersburgh, (or to speak more correctly the mean annual temperature of that city which is in lat. $59^{\circ} 56^{\prime}$ ), is found on the east coast of America in lat. $47 \frac{1}{2}^{\circ}$, or $12 \frac{1}{2}^{\circ}$ more to the south; in like manner we find the climate of Konigsberg, (lat. $54^{\circ} 43^{\prime}$ ), at Halifax, (lat. $44^{\circ} 39^{\prime}$ ). The temperature of Toulouse, (lat. $43^{\circ} 36^{\prime}$ ) corresponds to that of Washington (lat. $38^{\circ} 53^{\prime}$ ).

It would be very hazardous to lay down any general statements respecting the temperature in the territory of the United States of America, as we must distinguish in that territory three regions:-1, the Atlantic States east of the Alleghanies; 2, the Western States in the wide basin between the Alleghanies and the Rocky Mountains, through which flow the Mississipi, the Ohio, the Arkansas, and the Missouri ; 3, the high plains between the Rocky Mountains, 
and the Maritime Alps of New California through which the Oregon or Columbia River finds a passage. Since the highly honourable establishment, by John Calhoun, of uninterrupted observations of temperature, made on an uniform plan at 35 military posts, and reduced to daily, monthly, and annual means, we have arrived at more just climatic views than those which were so generally received in the time of Jefferson, Barton, and Volney. These meteorological stations or observatories extend from the point of Florida and Thompson's Island, (Key West), lat. 24 $33^{\circ}$, to the Council Bluffs on the Missouri; and if we reckon amongst them Fort Vancouver, lat. $45^{\circ} 37^{\prime}$, they include differences of longitude of $40^{\circ}$.

It cannot be affirmed that, on the whole, the mean annual temperature of the second or middle region is higher than that of the first or Atlantic region. The further advance of certain plants towards the north, on the west of the Alleghany mountains, depends partly on the nature of those plants, and partly on the different distribution of the same annual quantity of heat. The wide valley of the Mississipi enjoys at its northern and southern extremities the warming influence of the Canadian Lakes, and of the Mexican Gulf stream. The five lakes, (Superior, Michigan, Huron, Erie, and Ontario), occupy a space of 92,000 English square miles. The climate is much milder and more equable in the neighbourhood of the lakes; for example, at Niagara, (lat. $43^{\circ} 15^{\prime}$ ), the mean winter temperature is only half a degree of Reaumur ( $1^{\circ} .2$ Fahrenheit) below the freezing point, while at a distance from the lakes, in lat $44^{\circ} 53^{\prime}$, at the 
confluence of the river St. Peter's with the Mississipi, the mean winter temperature of Fort Snelling is $-7^{\circ} .2$ Reaumur, or $15^{\circ} .9$ Fahrenheit (see Samuel Forry's excellent Memoir on "the Climate of the United States," 1842, p. 37, 39, and 102.) At this distance from the Canadian Lakes, (whose surface is from 500 to $600-530$ to 640 Englishfeet above the level of the sea, whilst the bottom of the lakes Michigan and Huron is about five hundred feet below it), recent observations have shewn the climate of the country to possess a proper continental character, $i$. e., hotter summers and colder winters. "It is proved," says Forry, "by our thermometrical data, that the climate west of the Alleghany Chain is more excessive than that of the Atlantic side." At Fort Gibson, on the Arkansas River which falls into the Mississipi in lat. $35^{\circ} 47^{\prime}$, with a mean annual temperature hardly equal to that of Gibraltar, the thermometer in the shade, and without any reflected heat from the ground, has been seen, in August 1834, to rise to $37^{\circ} .7$ Reausaur, or $117^{\circ}$ Fahrenheit.

The statement so often repeated, although unsupported by any thermometric measurements, that since the first European settlements in New England, Pennsylvania, and Virginia, the eradication of many forests on both sides of the Alleghanies had rendered the climate more equable, (i. e., milder in winter and cooler in summer), is now generally doubted or disbelieved. Series of trustworthy thermometric observations in the United States hardly extend so far back as 78 years. We see in the Philadelphia observations, 
that from 1771 to 1824 , the mean annual temperature has hardly increased $1^{\circ} .2$ Reaumur, (or $2^{\circ} .8$ Fahrenheit), - a difference which is attributed to the increased size of the town, to its greater population, and to the numerous steamengines. The difference may possibly be merely accidental, for $I$ find in the same period an increase of mean winter cold, amounting to $0^{\circ} .9$ Reaumur, or $2^{\circ}$ Fahrenheit; the three other seasons had become somewhat warmer. Threeand-thirty years' observations at Salem in Massachusetts shew no alteration at all: the annual means oscillate, within a degree of Fahrenheit, about the mean of the whole number of years; and the winters of Salem, instead of having become milder, as supposed from the destruction of the forests in the course of the thirty-three years, have become colder by $1^{\circ} .8$ Reaumur, or $4^{\circ}$ Fahrenheit. (Forry, p. 97, 101, and 107.)

As the east coast of the United States is comparable in respect to mean annual temperature in equal latitudes to the Siberian and Chinese coasts of the old continent, so also the west coasts of Europe and America have been very properly compared together. I will only take a few examples from the western region on the shores of the Pacific, for two of which (Sitka in Russian America, and Fort George, in the same latitudes respectively as Gottenburg and Geneva) I am indebted to Admiral Lütke's voyage of circumnavigation. Tluluk and Danzig are nearly on the same parallel, and although the mean temperature of Iluluk, owing to its insular climate and to a cold sea- 
current, is somewhat lower than that of Danzig, yet the winter temperature of the American station is milder than that of the port on the Baltic.

\begin{tabular}{|l|r|r|r|r|}
\hline Sitka . . . & $57^{\circ} 3^{\prime}$ & $135^{\circ} 16^{\prime} \mathrm{W}$. & $5^{\circ} .6 \frac{0^{\circ} .6}{10^{\circ} .2}$ & $44^{\circ} .5 \frac{33^{\circ} .4}{55^{\circ} .0}$ \\
Gottenburg. . & $57^{\circ} 41^{\prime}$ & $1^{\circ} 59^{\prime} \mathrm{E}$. & $6^{\circ} . \frac{-0^{\circ} .2}{13^{\circ} .5}$ & $46^{\circ} .4 \frac{31^{\circ} .5}{62^{\circ} .4}$ \\
Fort George . & $46^{\circ} 18^{\prime}$ & $122^{\circ} 58^{\prime} \mathrm{W}$. & $8^{\circ} .1 \frac{2^{\circ} .6}{12^{\circ} .4}$ & $50^{\circ} .3 \frac{37^{\circ} .9}{60^{\circ} .0}$ \\
Geneva . . . & $46^{\circ} 12^{\prime}$ & $($ Alt. $1298 \mathrm{E.ft.})$. & $7^{\circ} .9 \frac{0^{\circ} .7}{14^{\circ} .0}$ & $49^{\circ} .8 \frac{33^{\circ} .6}{63^{\circ} .5}$ \\
Kherson. . . & $46^{\circ} 38^{\prime}$ & $32^{\circ} 39^{\prime} \mathrm{E}$. & $9^{\circ} .4 \frac{3^{\circ} .1}{17^{\circ} .3}$ & $53^{\circ} .2 \frac{25^{\circ} .0}{71^{\circ} .0}$ \\
\hline
\end{tabular}

Snow is hardly ever seen on the banks of the Oregon or Columbia river, and ice on the river lasts only a very few days. The lowest temperature which Mr. Ball once observed there in the winter of 1833 was $6 \frac{1}{2}^{\circ}$ of Reaumur below the freezing point, or $17.4^{\circ}$ Fahrenheit (Message from the President of the United States to Congress, 1844, p. 160 ; and Forry, Clim. of the U. States, p. 49, 67, and 73). A cursory glance at the summer and winter temperatures above given, shews that on and near the west coast, a true insular climate prevails. The winter cold is less than in the western parts of the old continent, and the summers are much cooler. The most striking contrast is presented 
by comparing the mouth of the Oregon with Forts Snelling and Howard, and the Council Bluffs, in the interior of the Mississipi and Missouri basin (Lat. $44^{\circ}-46^{\circ}$ ), where, to speak in the language of Buffon, we find an excessive, or true continental climate,-a winter cold, on single days, of $-28^{\circ} .4$ and $-30^{\circ} .6$ Reaumur $\left(-32^{\circ}\right.$ and $-37^{\circ} \mathrm{Fahr}$.), followed by mean summer temperatures of $16^{\circ} .8$ and $17^{\circ} .5$ Reaumur $\left(69^{\circ}\right.$ and $71^{\circ} .4$ Fahr.)

\section{${ }^{(19)}$ p. 10.- "As if America had emerged later from the chaotic watery covering."}

An acute enquirer into nature, Benjamin Smith Barton, said long since with great truth, (Fragments of the Natural History of Pennsylvania, P. i. p. 4), "I cannot but deem it a puerile supposition, unsupported by the evidence of nature, that a great part of America has probably later emerged from the bosom of the ocean than the other continents." The same subject was touched on by myself in a memoir on the primitive nations of America (Neue Berlinische Monatschrift, Bd. xv. 1806, S. 190). "Writers generally and justly praised have repeated but too often that America is in every sense of the word a New Continent. Her luxuriance of vegetation, the abundant waters of her enormous rivers, the unrepose of her powerful volcanoes, all (say they) proclaim that the still trembling earth, from the face of which the waters have not yet dried off, is here nearer to the chaotic primordial state than in the Old Continent. Such ideas appeared to me, long before I commenced my travels, alike unphilosophical and con- 
trary to generally acknowledged physical laws. Fantastic images of terrestrial youth, and unrepose associated on the one hand,- -and on the other, those of increasing dryness, and inertia in maturer age,-could only have presented themselves to minds more inclined to draw ingenious or striking contrasts between the two hemispheres, than to strive to comprehend, in one general view, the construction of the entire globe. Are we to regard the south of Italy as more modern than its northern portions, because the former is almost incessantly disquieted by earthquakes and volcanic eruptions? Besides, what small phenomena are the volcanoes and earthquakes of the present day, in comparison with those revolutions of nature which the geologist must suppose to have accompanied, in the chaotic state of the earth, the elevation, solidification, disruptions, and cleavings of the mountain masses? Diversity of causes must produce diversity in the operations of natural forces, in countries remote as well as near. Perhaps the volcanoes of the new continent, (of which I still reckon above 28 in a state of activity), have only continued to burn longer than others, because the lofty mountain ridges, on which they have broken forth in rows or series above long subterranean fissures, are nearer to the sea, and because this proximity seems, with a few exceptions, to affect the energy of the subterranean fires in some way not yet sufficiently explained. Besides, both earthquakes and fire-emitting mountains have periods of activity alternating with periods of repose. "At the present moment," (I wrote thus 42 years ago!) " physical disquiet and political calm reign in the New 
Continent, while in the Old the desolating strife of nations disturbs the enjoyment of the repose of nature. Perhaps a time is coming when, in this singular contrast between physical and moral forces, the two sides of the Atlantic will change parts. Volcanoes are quiescent for centuries before they burst forth anew; and the idea that in the so-called older countries, a certain peace must prevail in nature, is founded on a mere play of the imagination. There exists no reason for assuming one entire side of our planet to be older or newer than the other. Islands are indeed raised from the bed of the ocean by voleanic action, and gradually heightened by coral animals, as the Azores and many low flat islands of the Pacific ; and these may indeed be said to be newer than many Plutonic formations of the European central chain. A small district of the earth, surrounded, like Bohemia and Kashmeer, (and like many of the vallies in the Moon), by annular mountains, may, by partial inundations, be long covered with water ; and after the flowing off of this lake or inland sea, the ground on which vegetation begins gradually to establish itself might be said, figuratively, to be of recent origin. Islands have become connected with each other by the elevation of fresh masses of land; and parts of the previously dry land have been submerged by the subsidence of the oscillating ground; but submersions so general as to embrace a hemisphere, can, from hydrostatic laws, only be imagined as extending at the same time over all parts of the earth. The sea cannot permanently overflow the boundless plains of the Orinoco and the Amazons, without also over- 
whelming the plains adjoining the Baltic. The sequence and identity of the sedimentary strata, and of the organic remains of plants and animals belonging to the ancient world enclosed in those strata, shew that several great depositions have taken place almost simultaneously over the entire globe." (For the fossil vegetable remains in the coal formation in North America and in Europe, compare Adolph Brongniart, Prodrome d'une Hist. des Végétaux Fossiles, p. 179; and Charles Lyell's Travels in North America, vol. ii. p. 20).

$\left.{ }^{20}\right)$ p. 10.- "The Southern Hemisphere is cooler and moister than our Northern half of the globe."

Chili, Buenos Ayres, and the southern parts of Brazil and Peru, have all, as a result of the narrowness of the continent of South America as it tapers towards the south, a true "insular climate; or a climate of cool summers and mild winters. As far as the 48th or 50th parallel of latitude this character of the Southern Hemisphere may be regarded as an advantage, but farther on towards the Antarctic Pole, South America gradually becomes an inhospitable wilderness. The difference of latitude of the southern terminating points of Australia, (including Van Diemen Island), of Africa, and of America, - gives to each of these continents a peculiar character. The Straits of Magellan are between the 53d and 54th degrees of latitude, and yet in December and January, when the sun is 18 hours above the horizon, the temperature sinks 
to $4^{\circ}$ Reaumur, or $41^{\circ}$ Fahrenheit. Snow falls almost daily, and the highest atmospheric temperature observed by Churruca (1788) in December, (the summer of those regions), was not above $9^{\circ} \mathrm{R}$., or $52^{\circ} .2$ Fahr. The Cabo Pilar, whose towering rock, though only 218 toises, or 1394 English feet high, may be regarded as the southern termination of the chain of the Andes, is almost in the same latitude as Berlin. (Relacion del Viage al Estrecho de Magallanes, apendice, 1793, p. 76.)

While in the Northern Hemisphere all the continents attain a sort of mean limit towards the Pole, coinciding pretty regularly with the parallel of $70^{\circ}$, the terminating points in the Southern Hemisphere,- of America, in the deeply indented and intersected Tierra del Fuego, - of Australia, -and of Africa,-are respectively $34^{\circ}, 46 \frac{1}{2}^{\circ}$, and $56^{\circ}$ distant from the south pole. The temperature of the very unequal extents of ocean, which divide these southern points from the icy pole, contributes very materially to modify their climates. The areas of dry land in the Northern and Southern Hemispheres are to each other in the proportion of 3 to 1 . But this inferiority in extent of continental masses in the Southern Hemisphere, as compared with the Northern, belongs much more to the temperate than to the torrid zone. In the temperate zones of the Northern and Southern Hemispheres, the ratio is as 13 to 1 ; in the torrid zones as 5 to 4 . The great inequality in the distribution of the dry land exercises a very sensible influence on the strength of the ascending aerial 
current which turns towards the southern pole, and on the temperature of the Southern Hemisphere. Some of the noblest forms of tropical vegetation, for example the tree-ferns, advance south of the equator as far as the parallels of $46^{\circ}$, and of even $53^{\circ}$; whereas north of the equator they are not found beyond the tropic of Cancer. (Robert Brown, Appendix to Flinders' Voyage, p. 575 and 584; Humboldt, de distributione geographica Plantarum, p. 81-85.) Tree-ferns thrive extremely well at Hobart Town in Van Diemen Island, (lat $42^{\circ} 53^{\prime}$ ), where the mean annual temperature is $9^{\circ}$ Reaumur, or $52^{\circ} .2$ Fahrenheit, and is therefore $1^{\circ} .6$ Reaumur, or $3^{\circ} .6$ Fahrenheit, less than that of Toulon. Rome is almost a degree of latitude farther from the equator than Hobart Town, and has an annual temperature of $12^{\circ} .3 \mathrm{R}$., or $59^{\circ} .8 \mathrm{Fahr}$; - a winter temperature of $6^{\circ} .5 \mathrm{R}$., or $46^{\circ} .4 \mathrm{Fahr} .,-$ and a summer temperature of $24^{\circ} \mathrm{R}$., or $86^{\circ} \mathrm{Fahr}$; these three values being in Hobart Town $8^{\circ} .9,4^{\circ} .5$, and $13^{\circ} .8$ R., or $52^{\circ} .0,42^{\circ} .2$, and $63^{\circ}$. Fahr. In Dusky Bay, New Zealand, tree-ferns grow in S. lat. $46^{\circ} 8^{\prime}$, and in the Auckland and Campbell Islands, even in $53^{\circ} \mathrm{S}$. lat. (Jos. Hooker, Flora Antarctica, 1844, . p. 107.)

In the Archipelago of Tierra del Fuego,-where, in the same latitude as Dubiin, the mean winter temperature is $0^{\circ} .4$ Reaumur, ( $33^{\circ}$ Fah.) and the mean summer temperature only $8^{\circ}$ R., or $50^{\circ}$ Fahr.,-Captain King found the "vegetation thriving most luxuriantly in large woody-stemmed trees of Fuchsia and Veronica"; while this vigour of vegetation, which, especially on the western coast of America 
in $38^{\circ}$ and $40^{\circ}$ of south latitude, is so picturesquely described by Charles Darwin, suddenly disappears south of Cape Horn, on the rocks of the Southern Orkney and Shetland Islands, and of the Sandwich Archipelago. These Islands, but scantily covered with grass, moss, and lichens, “Terres de Désolation," as the French navigators call them, are still far north of the Antarctic Circle; whereas in the Northern Hemisphere in $70^{\circ}$ of latitude, at the extremity of Scandinavia, fir-trees attain a height of between 60 and 70 English feet. (Compare Darwin in the "Journal of Researches," 1845, p. 244, with King in vol. i. of the Narrative of the Voyages of the Adventure and Beagle, p. 577.) If we compare Tierra del Fuego, and particularly Port Famine in the Straits of Magellan in lat. $53^{\circ} 38^{\prime}$, with Berlin, which is one degree nearer the equator, we find for

Berlin $6^{\circ} 8, \frac{-0^{\circ} .5}{13^{\circ} .9}$ R., $47^{\circ} .2, \frac{30^{\circ} .8}{63^{\circ} .2}$ Fahr.; and for Port Famine $4^{\circ} .7, \frac{1^{\circ} .2}{8^{\circ} .0}$ R., $42^{\circ} .6, \frac{34^{\circ} .8}{50^{\circ} .0}$ Fahr.

I subjoin in one view the few well-assured temperature data which we at present possess, for the lands of the temperate zone in the Southern Hemisphere, and which may be compared with the temperatures of the Northern Hemisphere, in most parts of which the distribution into summer heat and winter cold is so different and so much less equable. I employ the convenient method of notation before used and explained in pages 129-131. 


\begin{tabular}{|c|c|c|c|}
\hline \multirow{2}{*}{ Place. } & \multirow{2}{*}{$\begin{array}{c}\text { South } \\
\text { Latitude. }\end{array}$} & \multicolumn{2}{|c|}{$\begin{array}{l}\text { Mean Annual, Winter, and } \\
\text { Summer Temperature. }\end{array}$} \\
\hline & & Keaumur. & Fahrenheit. \\
\hline $\begin{array}{l}\text { Sidney and Paramatta } \\
\text { (New Holland.) }\end{array}$ & $33^{\circ} .50^{\prime}$ & $14^{\circ} .5 \frac{10^{\circ} .0}{20^{\circ} .2}$ & $64^{\circ} .5 \frac{54^{\circ} .5}{77^{\circ} .5}$ \\
\hline 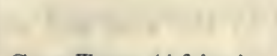 & & $11^{\circ} .8$ & $58^{\circ} 5$ \\
\hline Cape Town (Africa.) & $33^{\circ} .55^{\prime}$ & $15^{\circ} .0 \overline{18^{\circ} .3}$ & $65^{\circ} .7 \overline{73^{\circ} .3}$ \\
\hline Buenos Ayres • . & $34^{\circ} .17^{\prime}$ & $13^{\circ} .5 \frac{9^{\circ} .1}{18^{\circ} .2}$ & $62^{\circ} \cdot 4 \frac{52^{\circ} .5}{73^{\circ} .0}$ \\
\hline Monte Video . . & $34^{\circ} .54^{\prime}$ & $15^{\circ} .5 \frac{11^{\circ} .3}{20^{\circ} .2}(?)$ & $66^{\circ} .8 \frac{57^{\circ} .3}{77^{\circ} .5}$ \\
\hline $\begin{array}{c}\text { Hobart Town (Van } \\
\text { Diemen Island.) }\end{array}$ & $42^{\circ} .45^{\prime}$ & $9^{\circ} .1 \frac{4^{\circ} .5}{13^{\circ} .8}$ & $52^{\circ} .5 \frac{42^{\circ} .2}{63^{\circ} .0}$ \\
\hline $\begin{array}{l}\text { Port Famine (Straits } \\
\text { of Magellan.) . }\end{array}$ & $53^{\circ} .38^{\prime}$ & $4^{\circ} .7 \frac{1^{\circ} .2}{8^{\circ} .0}$ & $42^{\circ} \cdot 6 \frac{34^{\circ} .8}{50^{\circ} .0}$ \\
\hline
\end{tabular}

\section{(21) p. 11._- A connected Sea of Sand."}

As the Heaths formed of sociąlly growng Ericeæ, which stretch from the mouth of the Scheldt to that of the Elbe and from the point of Jutland to the Harz, may be regarded as one connected tract of vegetation, - so the seas of sand may be traced through Africa and Asia, from Cape Blanco to beyond the Indus, or through an extent of 5600 geographical miles. Herodotus's Sandy Region interrupted by Oases, called by the Arabs the Desert of Sahara, traverses almost the whole of Africa, which it intersects 
like a dried-up arm of the sea. The valley of the Nile is the eastern limit of the Lybian Desert. Beyond the Isthmus of Suez, beyond the porphyritic, syenitic, and basaltic rocks of Sinai, begins the Desert mountain plateau of Nedjid, which occupies the whole of the interior of the Arabian Peninsula, and is bounded to the west and south by the fertile and happier coast lands of Hedjaz and Hadhramaut. The Euphrates bounds the Arabian and Syrian Deserts towards the east. Immense seas of sand, (bejaban), cross Persia from the Caspian to the Indian Sea. Among them are the salt and soda Deserts of Kerman, Seistan, Beloochistan, and Mekran. The latter is separated from the Desert of Moultan by the Indus.

(22) p. 11.- "The western part of the Atlas."

The question respecting the position of the ancient Atlas has heen much discussed in modern times, but the oldest Phœnician legends have been confounded in this discussion with the later fables of the Greeks and the Romans. A man who combined deep philological with thorough mathematical and astronomical knowledge, Professor Ideler, (the father,) was the first person who explained and dispelled the confusion of ideas which had previously existed on this subject. I permit myself to introduce here the remarks that clear-sighted and highly-informed writer has communicated to me on this important subject.

"At a very early period of the world the Phœnicians ventured beyond the Straits of Gibraltar. They built Gades and Tartessus on the Spanish, and Lixus and several other 
towns on the Mauritanian coasts of the Atlantic. They sailed along those coasts northwards to the Cassiterides where they obtained tin, and to the Prussian coast from whence they brought amber; and southwards, past Madeira, to the Cape de Verde Islands. They visited, among other places, the Camaries, and were struck by the appearance of the lofty Peak of Teneriffe, enhanced by its rising immediately from the sea. Through the colonies which they sent to Greece, and especially through that which came under Cadmus to Bootia, the notice of this mountain rising high above the region of clouds, and of the "Fortunate Islands," adorned with fruits of every kind, and especially with the golden orange, spread into Greece. Here the tradition was propagated by the songs of the bards, and thus reached Homer. He speaks in the Odyssey (i. 52) of an "Atlas who knows all the depths of the sea, and who suppo ts the great pillars which divide heaven and earth from each other." $\mathrm{He}$ speaks, too, in the Dliad, of the Elysian fields, which he describes as a lovely land in the west. (Il. iv. 561.) Hesiod expresses himself in a similar manner respecting Atlas, who he makes a neighbour of the nymphs the daughters of Hesperus. (Theog. V. 517.) He calls the Elysian fields, which he places at the western limit of the earth, the islands of the Blest. (Op. et dies, v. 167.) Later poets have added further embellishments to these myths of Atlas, of the Hesperides, their golden apples, and the Islands of the Blest, assigned as the dwelling-place of the virtuous after death; and have combined with them the expeditions of the Tyrian god of trade, Melicertes (the Grecian Hercules). 
"The Greeks only began at a very late date to rival the Phœnicians and Carthaginians in navigation. They visited the coasts of the Atlantic it is true, but never appear to have penetrated far into the ocean. I doubt whether they ever saw the Canaries and the Peak of Teneriffe. They believed that Atlas, which their poets and legends described as a very high mountain placed at the western limit of the earth, must be sought on the west coast of Africa. It was placed there also by their later geographers, Strabo, Ptolemy, and others. As there is not any single mountain distinguished by its elevation in north-western Africa, the true situation of Mount Atlas has been a subject of perplexity; and it has been sought, sometimes on the coast, sometimes in the interior, sometimes near the Mediterranean, and sometimes further towards the south. It became the custom (in the first century of our era, when the Roman arms penetrated into the interior of Mauritania and Numidia,) to give the name of Atlas to the African chain of mountains which runs from west to east almost parallel with the coast of the Mediterranean. Pliny and Solinus were, however, very sensible that the descriptions of Mount Atlas given by the Greek and Koman poets were not applicable to this long mountain chain; and they therefore thought it necessary to transfer the Atlas, of which they gave a picturesque description in accordance with the poetic legends, to the terra incognita of Central Africa. According to what has been said, the Atlas of Homer and Hesiod can only be the Peak of Teneriffe; and the Atlas of the Greek and Roman geographers must be in Northern Africa." 
I will only add the following remarks to this instructive discussion by Professor Ideler. According to Pliny and Solinus, Atlas rises from a sandy plain (e medio arenarum); and elephants (which certainly were never known in Teneriffe) feed on its declivity. What we now term Atlas is a long ridge. How came the Romans to recognise in this long ridge the isolated conical mountain of Herodotus? May not the reason be found in the optical delusion by which every mountain chain seen in profile, in the prolongation of its direction, has the appearance of a narrow cone? I have often seen in this manner, from the sea, the ends of long chains or ridges, which might be taken for isolated mountains. According to Höst the Atlas is covered near Morocco with perpetual snow, which implies an elevation of above 1800 toises, or 11510 English feet. It is also remarkable that, according to Pliny, the "Barbarians," i.e. the ancient Mauritanians, called the Atlas "Dyris." The chain of the Atlas is still called by the Arabs Daran, a word which has almost the same consonants as Dyris. Hornius, on the other hand (de Originibus Americanorum, p. 195), thinks that he recognises the word Dyris in the Guanche name of the Peak of Teneriffe, Aya-Dyrma. On the connection between purely mythical ideas and geographical traditions, and on the way in which the Titan Atlas gave occasion to the image of a mountain supporting the heavens, beyond the Pillars of Hercules, see Letronne's “Essai sur les Idées cosmographiques qui se rattachent au nom d'Atlas," in Férussac's Bulletin universel des Sciences, Mars 1831, p. 10. 
Considering that our present (it is true, very limited) geological knowledge of the mountainous parts of North Africa does not make us acquainted with any trace of volcanic eruptions within historic times, it is very remarkable to find among the ancients so many indications of a belief in the existence of this class of phenomena, in the Western Atlas, and in the neighbouring west coast of the continent. The streams of fire, so often mentioned in Hanno's ship-journal, may indeed have only been strips of burning grass, or signal fires kindled by the wild inhabitants of the coasts to give to each other notice of the danger threatened by the appearance of the hostile vessels. The lofty flame-enlightened summit of the "chariot of the gods" $(\theta \varepsilon \tilde{\omega} \boldsymbol{\nu}$ ö $\chi \mu a)$, may recall obscurely the Peak of Teneriffe; but farther on Hanno describes a singular conformation of ground. He finds in the Gulf near the Western Horn, a large island, and in it a salt lake which again contains a smaller island. South of the bay of the Gorilla Apes, the same conformation is repeated. Is this a description of coral productions, of "lagoon islands, (Atolls)" or volcanic "crater lakes" in the middle of which a cone has been upheaved? The Triton lake was not in the neighbourhood of the lesser Syrtis, but near the Atlantic coast. (Asie Cent. T. i. p. 179.) The lake disappeared in consequence of earthquakes which were accompanied by great outbursts of fire. Diodorus (Lib. iii. 53, 55) says expressly,

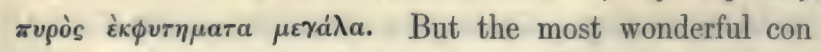
formation is ascribed to the "hollow Atlas" in a passage hitherto little noticed, occurring in one of the philosophic 
Dialexes of Maximus Tyrius. This Platonic philosopher lived in Rome, under Commodus. The situation of his Atlas is "on the continent, where the Western Lybians inhabit a projecting peninsula. The mountain has in it towards the sea a semicircular deep abyss. The precipices are so steep that they cannot be descended; the abyss below is filled with trees, and "one looks down upon their summits, and on the fruits which they bear, as if one was looking into a well.” (Maximus Tyrius, viii., 7, ed. Markland.) The description is so graphic and so individually marked, that it doubtless conveys the recollections impressed. by a real prospect.

$\left.{ }^{23}\right)$ p. 11.- "The Mountains of the Moon, Djebel al Komr."

The Mountains of the Moon of Ptolemy (Lib. iv. cap. 9, ) ( $\sigma \varepsilon \lambda \dot{\nu} \nu \eta$ sópos) fcrm on our older maps an immense uninterrupted mountain zone, traversing Africa from east to west. The existence of these mountains appears certain; but their extent, their distance from the Equator, and their general direction, are ail unsolved problems. I have already alluded in another work, (Cosmos, vol. ii. p. 191, and note 297, Engl. ed.) to the manner in which a closer acquaintance with Indian languages, and with the ancient Persian idiom, the Zend, teaches us that part of the geographical nomenclature of Ptolemy forms an historic monument of the commercial connection of the west with the most distant regions of Southern Asia and Eastern Africa. The same direction of ideas shews itself in a question very recently 
brought forward. It is asked, whether the great geographer and astronomer of Pelusium meant in the name of "Mountains of the Monn," as in that of the "Island of Barley" (Jabadiu, Java), merely to give the Greek translation of a native name;-whether (as is most probable) El Istachri, Edrisi, Tbn-al-Vardi, and other early Arabian geographers, only transferred the nomenclature of Ptolemy into their own language ; - or whether they were misled by similarity in the sound of the words and the manner of writing. In the notes to the translation of Abd-Allatif's celebrated description of Egypt, my great instructor, Silvestre de Sacy, (éd. de 1810, p. 7 and 353,) says expressly: "On traduit ordinairement le nom de ces montagnes que Léon Africain regarde comme les sources du Nil, par montagnes de la lune, et j'ai suivi cet usage. Je ne sais si les Arabes ont pris originairement cette dénomination de Ptolémée. On peut croire qu’ils entendent effectivement aujourd'hui le mot, قـ dans le sens de la lune en le prononçant 'Kamar'; je ne crois pas cependant que ç'ait été l'opinion des anciens écrivains arabes qui prononcent, comme le prouve Makrizi, Komr. Aboulféda rejette positivement l'opinion de ceux qui prononcent kamar, et qui dérivent ce nom de celui de la lune. Comme le mot komr, considéré comme pluriel de, أقagnifie un objet d'une couleur verdâtre on d'un blanc sale, suivant Yauteur du Kamous, il paroit que quelques écrivains ont cru que cette montagne tiroit son nom de sa couleur."

Tise learned Reinaud, in his recent excellent translation of Abulfeda (T. ii., P. i., p. 81-82), considers it probable that the Ptolemaic interpretation of the name, by "Mountains 
of the Moon" (" $\rho \eta \sigma \varepsilon \lambda \eta \nu a \tilde{a} a)$, was that originally adopted by the Arabian writers. He remarks that in the Moschtarek of Yakut, and in Ibn-Said, the mountains are written alKomr, and that Yakut writes in the same way the name of the island of 'Lendj (Zanguebar). The Abyssinian traveller Beke, in his learned critical memoir on the Nile and its tributaries (Journal of the Royal Geographical Society of London, vol. xvii. 1847, p. 74-76), seeks to prove that Ptolemy had merely formed his $\sigma \varepsilon \lambda \eta \nu \eta s$ yoos from a native name, for which he was indebted to intelligence received through the medium of the extensive commercial intercourse which prevailed. He says, "Ptolemy knew that the Nile rises in the mountainous country of Moezi; and in the languages which extend over a great portion of South Africa (for example, in the languages of Congo, Monjou, and Mozambique), the word Moezi signifies the moon. A great south-western country was called MonoMuezi, or Mani-Moezi, i. e. the land of the king of Moezi (of the king of the Moon country), for in the same family of languages in which Moezi or Muezi signifies the Moon, Mono or Mani signifies a king. Alvarez, in the Viaggio nella Ethiopia (Ramusio, vol. i., p. 249,) speaks of the 'regne di Manicongo,' the kingdom of the king of Congo." Beke's opponent, Ayrton, seeks the origin of the White Nile (Bahr el Abiad), not as do Arnaud, Werne, and Beke, near the equator, or even south of it (and in $29^{\circ} \mathrm{E}$. long. from Paris, or $31^{\circ} 22^{\prime}$ from Greenwich), but with Antoine d'Abbadie far to the north-east, in the Godjeb and Gibbe of Eneara (Iniara); therefore in the high mountains of 
Habesch, in $7^{\circ} 20^{\prime} \mathrm{N}$. latitude, and $33^{\circ} \mathrm{E}$. long. from Paris, or $35^{\circ} 2 z^{\prime}$ from Greenwich. He conjectures that the Arabs, from a similarity of sound, may have interpreted the native name Gamaro belonging to the Abyssinian mountains, in the south-west of Gaka in which the Godjeb (or White Nile?) has its source, to mean Moon Mountains (Djebel al-Kamar); so that Ptolemy himself, familiar with the intercourse between Abyssinia and the Indian Ocean, may have taken the Semitic version, given by early Arab immigrants. (Compare Ayrton in the Journal of the Royal Geogr. Soc. vol. xviii. 1848, p. 53, 55, and 59-63, with Fred. Werne's instructive expedition for the discovery of the sources of the Nile, Exped. zur Entd. der Nil-Quellen, 1848, S. 534-536.

The lively interest which has again been excited in England for the discovery of the most southern sources of the Nile, induced the above-named Abyssinian traveller, Charles Beke, at the recent meeting of the British Association for the Advancement of Science, held at Swansea, August 1848, to develope more in detail his ideas respecting the connection between the Mountains of the Moon and the Mountains of Habesch. He says:- "The Abyssinian elevated plain, generally above 8000 feet high; extends towards the south to nearly $9^{\circ}$ or $10^{\circ} \mathrm{N}$. latitude. The eastern declivity of the highlands has to the inhabitants of the coast the appearance of a mountain chain. The plateau at its southern extremity passes into the Mountains of the Moon, which run, not east and west, but parallel to the coast, or from NNE. to SSW.; extending. 
from $10^{\circ} \mathrm{N}$. to $5^{\circ} \mathrm{S}$. latitude. The sources of the White Nile are situated in the Mono-Moezi country, probably in $2 \frac{1}{2}^{\circ} \mathrm{S}$., not far from where the river Sabaki, on the eastern side of the Mountains of the Moon, falls into the Indian Ocean near Melindeh, north of Mombaza. Last autumn (1:47) the two Abyssinian missionaries Rebmann and Krapf were still on the coast of Mombaza. They have established in the vicinity, among the Wakamba tribe, a missionary station called Rabbay Empie, which promises to be very useful also for geographical discovery. Families belonging to the Wakamba tribe have advanced to the west five or six hundred miles into the interior of the country, as far as the upper course of the river Lusidji, the great lake Nyassi or Zambeze ( $5^{\circ} \mathrm{S}$. lat.?), and the sources of the Nile which are not far distant. An expedition to these sources, which Herr Friedrich Bialloblotzky, of Hanover, is preparing to undertake, (by the advice of Beke), is to set out from Mombaza. The Nile coming from the west referred to by the ancients is probably the Bahr-el-Ghazal, or Keilah, which falls into the Nile in $9^{\circ} \mathrm{N}$. lat., above the mouth of the Godjeb or Sobat."

Russegger's scientific expedition, - which by Mehemet Ali's desire was sent to the gold-washings of Fazokl on the Blue (Green) Nile, Bahr-el-Azrek, in 1837 and 1838, - had made the existence of the "Mountains of the Moon” appear very doubtful. The Blue Nile, the Astapus of Ptolemy, issuing from the lake of Coloe (now called lake Tzana) winds from amongst the colossal Abyssinian mountains; but towards the south-west an extensive low 
tract of country appears. The three exploring expeditions sent by the Egyptian government, (one in November 1839 from Charlum to the confluence of the Blue and the White Nile, under the command of Selim Bimbashi; another in the autumn of 1840, which was accompanied by the French engineers Arnaud, Sabatier; and Thibaud; and a third in August 1841), first unveiled the high mountains which, between the parallels of $6^{\circ}-4^{\circ}$, and probably still farther to the south, run at first from west to east, and afterwards from north-west to south-east, and approach the left bank of the Bahr-el-Abiad. The second of Mehemed Ali's expeditions first saw the mountain chain, according to Werne's account, in lat. $11 \frac{1}{3}^{\circ}$, where Gebel Abul and Gebel Kutak rise to 3400 (3623 Eng.) feet. The high land continued and approached nearer to the river more to the south, between $4 \frac{3}{4}^{\circ}$ lat., to the parallel of the island of Tschenker in $4^{\circ} 4^{\prime}$, where the expedition of Commander Selim and Feizulla Effendi terminated. The shallow river makes its way between rocks, and detached mountains rise again in the country of Bari to 3000 (3197 Eng.) feet. These probably belong to the Mountains of the Moon as represented in our most recent maps, although they are not indeed mountains covered with perpetual snow such as Ptolemy had described (lib. iv. cap. 9). The limit of perpetual snow in these latitudes would not certainly be found below an elevation of 14500 (15450 Eng.) feet. Perhaps Ptolemy transferred to the country of the sources of the White Nile the knowledge which he may have had of the high mountains of Habesch, which are nearer to 
Upper Egypt and to the Red Sea. In Godiam, Kaffa, Miecha, and Sami, the Abyssinian mountains rise to 10000 and 14000 (10657 and 14920 Eng.) feet, according to exact measurements; not according to Bruce, who gives the elevation of Chartum exceedingly wide of the truth, i. e., 4730 (5041 Eng.) feet, instead of 1430 (1524 Eng.) feet ! Rüppell, one of the most accurate observers of the present day, found Abba Jaret, in $18^{\circ} 10^{\prime}$ of latitude, only 66 (70 Eng.) feet lower than Mont Blanc. (Compare Rüppell, Reise in Abyssinien, Bd. i. S. 414, and Bd. ii. S. 443). Rüppell found, adjoining the Buahat, an elevated plain 13080 (13939 Eng.) feet above the Red Sea, barely covered with a small quantity of fresh fallen snow (Humboldt, Asie Centrale, T. iii. p. 272). The celebrated inscription of Adulis, which Niebuhr considers to be somewhat later than Juba and than Augustus, also speaks of Abyssinian snow "that reaches to the knees." This is, I believe, the earliest mention in antiquity of snow within the tropics (Asie Centrale, T. iii. p. 235) ; as the Paropanisus is $12^{\circ}$ of latitude north of the northern limit of the torrid zone.

Zimmermann's map of the countries about the Upper Nile shews the dividing line which determines the basin of the Great River, and separates it on the south-east from the domain of the rivers which flow into the Indian Ocean ;that is to say, from the Doard, which enters the sea north of Magadoxo; from the Teb, which has its embouchure on the Amber coast, near Ogda; and from the Goschop, whose abundant stream is formed by the confluence of 
the Gibu and the Zebi, and which he distinguishes from the Godjeb, rendered celebrated since 1839 by Antoine d'Abbadie, the missionary Krapf, and Beke. These results of the travels of Beke, Krapf, Isenberg, Russeger, Rüppell, Abbadie, and Werne, brought together and shewn in the most comprehensive and convenient manner by Zimmermann, were hailed by me on their appearance in 1843 with the most lively joy, as expressed in a letter to Carl Ritter. "If," I wrote to him, " a life prolonged to an advanced period brings with it several inconveniences to the individual, and perhaps some even to those who live with him, there is a compensation in the delight of being able to compare older states of knowledge with that which now exists, and to see great advances in knowledge grow and develope themselves under our eyes in departments where all had long slumbered in inactivity, with the exception, perhaps, of attempts by hypercriticism to render previous acquisitions doubtful. This enjoyment has from time to time fallen to our share, yours and mine, in our geographical studies, and this particularly in reference to those very parts of the world which formerly could only be treated of with timid hesitating uncertainty. The conformation of a continent depends in its leading traits on several plastic relations which are usually among the latest to be discovered and unravelled. A new and excellent work of our friend Carl Zimmermann, on the upper country of the Nile and the eastern parts of central Africa, has again brought these considerations very vividly before me. His new map shews in the clearest manner to the eye, by 
means of a particular method of shading, what is still unknown, and what, by the courage and perseverance of travellers of all nations,- - among whom our own countrymen happily hold an important place, - has been already disclosed to us. It is a valuable service, and one which opens the way for farther auvances and more comprehensive inferences, when persons, thoroughly acquainted with the existing, often widely scattered, materials, - men who do not merely draw and compile, but compare, select, and, whereever it is possible, check and control the routes of travellers by astronomical determinations of position,- - undertake to represent graphically the results of the elements of knowledge possessed at the time. Those who have themselves given to the world so much as you have done, have an especial right to expect much; since their combinations have largely augmented the number of connecting points; yet I believe that when you executed your great work on Africa in 1822 you could hardly have expected so many accessions as we have now received." The knowledge acquired is, indeed, often only that of rivers, their direction, their branches, and the various synonyms by which they are called in dialects belonging to different families of languages; but rivers reveal to us by their course the form of the surface of the earth, and are at once the nourishers of vegetation, the channels of intercourse between men, and pregnant with unknown influences on the future.

The northerly course of the White Nile, and the southeasterly course of the great Goschop, would indicate that a 
swelling of the ground separates the domains or basins of these rivers. We know, indeed, but imperfectly, how such a swelling or elevation may be connected with the mountains of Habesch, and in what manner it may be continued southward beyond the equator. Probably, and this is also the opinion of my friend Carl Ritter, the Lupata mountains, which, according to the excellent Wilhelm Peters, extend to $26^{\circ} \mathrm{S}$. latitude, are connected with the elevated parts of the Earth's surface on the north side of the equator, (or with the Abyssinian mountains), hy the mountains of the Moon. The word "Lupata," we learn from the last-named African traveller, is used in the language of Tette as an adjective, meaning "closed." The chain of mountains would thus be called the "closed" or "barred." "The Lupata chain, of Portuguese writers," says Peters, " is about 90 legoas or leagues from the mouth of the Zambeze, and is only about two thousand feet high. The direction of this mountain rampart is north and south, but with occasional bends alternately to the east and to the west. It is sometimes interrupted by plains. Along the whole of the Zanzibar coast, the traders into the interior speak of this long but not very elevated ridge, which extends from $6^{\circ}$ to $26^{\circ} \mathrm{S}$. latitude, as far as the Factory of Lourenzo-Marques, on the Rio de Espiritu Santo (in the Bay da Lagoa, or Delagoa Bay of the English). The farther the Lupata chain advances towards the south, the nearer it approaches the coast, from which it is only fifteen legoas distant at LourenzoMarques." 
(24) p. 12.- "Caused by the great revolving current."

In the northern part of the Atlantic, between Europe, North Africa, and the New Continent, the waters of the ocean are driven round in a true revolving current, or circle. This general current,-which, from its cause, might be called a "Rotation Current,"-moves between the tropics, as is well known, with the trade wind, from east to west. It accelerates the passage of ships sailing from the Canaries to South America, and makes it almost impossible to sail "up stream," or in a direct line from Cartagena de Indias to Cumana. This set to the west, attributed to the trade winds, receives, however, in the Caribbean Sea, the accession of a much stronger movement, originating in a very remote cause, which was discovered as early as 1560 by Sir Humphrey Gilbert, (Hakluyt, Voyages, vol. iii. p. 14), and developed with greater certainty by Rennell in 1832. The Mosambique current, flowing from north to south between Madagascar and the east coast of Africa, sets on the Lagullas Bank, turns on the north side of it round the south point of Africa, and advances with much force up the western coast of the Continent to a little beyond the equator near the Island of St. Thomas. It gives at the same time a north-westerly direction to a part of the water of the South Atlantic, causing it to strike Cape St. Augustin, and to follow the coast of Guiana to beyond the mouth of the Orinoco, the Boca del Drago, and the coast of Paria. (Rennell, Investigation of the Currents of the Atlantic Ocean, 1832, p. 96 and 136.) The New Continent, from 
the Isthmus of Panama to the northern part of Mexico, opposes a barrier to the farther continuance of this movement of the waters, and thus the current is constrained to assume a northerly course off Veragua, and thence to follow the windings of the coast of Costa Rica, Mosquito, Campeachy, and Tabasco. The waters which enter the Mexican Gulf between Cape Catoche of Yucatan and Cape San Antonio of Cuba, after completing a great rotatory movement or circuit, by Vera Cruz, Tamiagua, the mouth of the Rio Bravo del Norte, and that of the Mississipi, force their way northwards through the Bahama Channel, and re-issue into the open ocean. Here they form the wellknown "Gulf Stream," a current or river of warm and rapidly moving water, flowing in an oblique or diagonal direction carrying it farther and farther from the North American coast. Ships from Europe bound for this coast, when uncertain in respect to their longitude, are enabled by this oblique direction of the current to direct their course, as soon as they reach the Gulf Stream, by observations of latitude only. The position of this great current was first indicated with accuracy by Franklin, Williams, and Pownall.

From the 41st degree of latitude, the river of warm water, which has been gradually diminishing in rapidity and increasing in breadth, turns suddenly to the east. It almost touches the southern edge of the great Newfoundland bank, where I found the greatest amount of difference between the temperature of the warm water of the Gulf stream, and that of the waters resting on the banks and subjected thereby to a cooling process. Before the stream 
reaches the westernmost of the Azores it divides into two branches, one of which, at least at certain seasons, advances towards Ireland and Norway, and the other towards the Canaries and the West Coast of Africa. This Atlantic rotatory movement, (described by me in more detail in the first volume of my Voyage to the Equinoctial Regions), explains the possibility of trunks of South, American and West Indian trees being carried, in spite of the trade winds, to the coasts of the Canary Islands, and stranded there. I have made many experiments on the temperature of the Gulf Stream in the vicinity of the Banks of Newfoundland. The Stream brings the warmer water of lower latitudes into more northern regions with much rapidity, and I have thus found its temperature two or three degrees of Reaumur $\left(5^{\circ}\right.$ to $7^{\circ}$ Fah.) higher than that of the adjacent unmoved masses of water, which form as it were the banks of the warm oceanic river.

The flying fish of the tropics (Exocetus volitans) accompanies the warm water of the Gulf Stream far into the temperate zone. Floating sea-weed (Fucus natans), chiefly taken up by the stream in the Gulf of Mexico, shews when a ship is entering the current, and the arrangement of the branches of the sea-weed shews the direction of the movement of the water. 'The mainmast of the English ship of war, the Tilbury, destroyed by fire on the coast of San Domingo, was carried by the Gulf Stream to the north coast of Scotland. Even casks filled with palm oil, the remains of the cargo of a ship wrecked off Cape Lopez on the coast

voL. I. 
of Africa, were carried in the same manner to Scotland*, after having twice traversed the whole breadth of the Atlantic; once from east to west with the equitorial current hetween $2^{\circ}$ and $12^{\circ} \mathrm{N}$. lat., and once from west to east by the aid of the Gulf Stream, between $45^{\circ}$ and $55^{\circ}$ N. lat. Rennell, in p. 347 of the "Investigation of Currents," relates the voyage of a bottle with papers enclosed, thrown overboard by the English ship Newcastle on the 20th of January, 1819, in lat. $38^{\circ} 52^{\prime}$, and long. $63^{\circ} 5 \mathrm{~s}^{\prime}$, which was picked up on the 2 nd of June, 1820 , at the Rosses, (near the Island of Arran), on the west coast of Ireland. A short time before my arrival at Teneriffe a stem of South American cedar (Cedrela odorata), well covered with lichens, had been cast ashore in the harbour of Santa Cruz.

Effects of the Gulf Stream in stranding on the Islands of Fayal, Flores, and Corvo in the Azores, bamboos, artificially cut pieces of wood, trunks of an unknown species of Pine from Mexico and the West Indian Islands, and corpses of men of unknown race with unusually broad faces, contributed to the discovery of America, by confirming Columbus in his belief of the existence to the westward of Asiatic countries and islands at no impassable

[* The circumstance referred to was even more remarkable. Casks of palm oil, part of the cargo of the ship wrecked near Cape Lopez, were conveyed by the current to Finmarken, and stranded near the North Cape. Vide Editor's note in the English translation of "Cosmos," vol. i. p. xevii.]-Tr. 
distance. The great discoverer even heard from the lips of settlers near the Cape de la Verga in the Azores, of some, "who, in sailing westward, had met decked or covered boats, manned by persons of strange and foreign appearance, and built apparently in such a manner that they could not founder,-almadias con casa movediza que nunca se hunden." There is highly credible and well-confirmed testimony to the fact, much as it has long been doubted, of natives of America, (probably Esquimaux from Greenland or Labrador), carried by currents or driven by storms from the North West, having actually crossed the Atlantic in their canoes and reached our shores. James Wallace, in his "Account of the Islands of Orkney, (1700, p. 60)," relates, that in 1682 a Greenlander was seen in his boat off the South Point of the Island of Eda by-several persons, who did not succeed in bringing him to shore. In 16 84 , a Greenland fisherman appeared in his boat off the Island of Westram. In the church at Barra there was suspended an Esquimaux boat, driven thither by currents and tempests. The inhabitants of the Orkneys call Greenlanders so appearing among them Finns or "Finnmen."

In Cardinal Bembo's History of Venice, I find a narrative to the effect that in 1508 a French ship captured near the English coast a small boat, with seven persons of a strange and foreign appearance. The description suits extremely well with Esquimaux, (homines erant septem mediocri statura, colore subobscuro, lato et putente vultu, cicatriceque una violacea signato.) No one understood their language. Their clothing was composed of fish skins 
sewn together. On their heads they wore "coronam e culmo pictam, septem quasi auriculis intextam." They ate raw flesh, and drank blood as we would wine. Six of the men died during the passage of the vessel, on board which they had been taken; but the seventh, a youth, was presented to the king of France, who was then at Orleans. (Bembo, Historia Venetæ, ed. 1718, lib. vii. p. 257).

The appearance of men called Indians on the western coasts of Germany, under the Othos, and under Frederic Barbarossa, in the 10th and 12th centuries, and even, as is related by Cornelius Nepos, (ed. Van Staveren, cur. Bardili, T. ii., 1820, p. 356), Pomponius Mela, (lib. iii. cap. 5, $\S 8$ ), and Pliny, (Hist. Nat., T. ii. p. 67), when Quintus Metellus Celer was Pro-consul in Gaul, may be explained by similar effects of currents and northwest winds of long continuance. A king of the Boii, others say of the Suevi, gave the shipwrecked dark-coloured men to Metellus Celer. Gomara, in his Historia Gen. de las Indias, (Saragossa, 1553, fol. vii.), refers to this account, and considers the Indians spoken of in it to have been natives of Labrador. "Si ya no fuesen de Tierra del Labrador, y los tuviesen, los Romanos por Indianos engañados ell el color." The appearance of Esquimaux on the northern coasts of Europe may be believed to have occurred more often in earlier times, because we know, from the researches of Rask and Finn Magnusen, that in the 11th and 12th centuries this race extended in considerable numbers, under the name of the Skrälinges of Labrador, even as far south as the "good Vinland;" i.e., the coast of Massa- 
chusets and Connecticut. (Kosmos, Bd. ii. S. 270 ; English ed.p. 234 ; Examen critique de l'Hist. de la Géographie, T. ii. p. 247-278.)

As the winter cold of the most northern parts of Scandinavia is softened by the influence of the Gulf Stream, by which American tropical fruits (cocoa nuts, and seeds of the Mimosa scandens and the Anacardium occidentale) are cast upon the shore beyond the 62nd degree oi latitude, so does Iceland also occasionally enjoy the beneficial influence of the extension of the warm waters of the Gulf Stream far to the northward. The coasts of Iceland as well as those of the Färoe Islands, receive a great deal of driftwood, which, coming formerly in greater abundance, was cut into beams and planks and used for building timber. Fruits of tropical plants, collected on the coast of Iceland, between Raufarhavn and Vapnafiord, testify the movement of the waters from the southward. (Sartorius von Waltershausen, physisch-geographische Skizze von Island, 1847, S. 22-35.)

\section{$\left.{ }^{25}\right)$ p. 12.— "Neither Lecideas nor other Lichens."}

In northern countries, the earth, if left bare, soon becomes covered with Bæomyces roseus, Cenomyce rangiferinus, Lecidea muscorum, L. icmadophila, and similar Cryptogamex, which prepare the way for the growth of grasses and herbaceous plants. In the tropics, where mosses' and lichens only abound in shady places, some species of succulent plants take their place. 
${ }^{(26)}$ p. 13. - "The care of animals yielding milk,........ The ruins of the Aztec fortress."

The two kinds of cattle alluded to, and subsequently spoken of,-the Bos americanus and Bos moschatus,-are peculiar to the American continent. But the natives-

Queis neque mos, neque cultus erat, nee jungere tauros.

Virgil, En. i. 316 .

-drink the fresh blood, not the milk, of these animals. Single exceptions have indeed been found, but only among tribes who at the same time cultivated maize. I have before remarked, (p. 54), that Gomara speaks of a people in the north-west of Mexico who possessed herds of tame bisons, and derived from these animals clothing, meat, and drink. The drink may have been the blood, (Prescott, Conquest of Mexico, vol. iii. p. 416) for, as I have more than once remarked, the dislike to milk, or at least the absence of its use, appears, before the arrival of Europeans, to have been, generally speaking, a feature common to all the natives of the New Continent,-and one which they possess in common with the inhabitants of China and Cochin China, who yet were near neighbours to true pastoral nations. The herds of tame lamas, found in the highlands of Quito, Peru, and Chili, belonged to a settled population, who cultivated the ground and did not follow a nomadic life. Pedro de Cieça de Leon, (Chronica del Peru, Sevilla, 1553, cap. 110, p. 264) seems to imply, though certainly as a rare and exceptional case, that in the Peruvian mountain plateau of Collao lamas were used for drawing the 
plough. (Compare Gay, Zoologia de Chile, Mamiferos, 1847, p. 154.) The usual custom in Peru was to plough with men only. (See the Inca Garcilaso's Commentarios reales, P. i. lib. v. cap. 2, p. 133 ; and Prescott, Hist. of the Conquest of Peru, 1847, vol. i. p. 136.) Mr. Barton has made it appear probable that, among some of the tribes of Western Canada, the buffalo was from early times made an object of care for the sake of its flesh and skin. (Fragments of the Nat. Histst. of Pennsylvania, P. i. p. 4.) In Peru and Quito the lama is now nowhere found in a state of original wildness. I was told by the natives that the lamas on the western declivity of the Chimborazo had become wild when the ancient residence of the rulers of Quito "Lican" was laid in ashes. In the same manner the oxen in the Ceja de la Montaña, in Middle Peru, have become perfectly wild : they are a small and daring race, and often attack.the Indians. The natives call them Vacas del Monte, or Vacas cimarronas. (Tschudi, Fauna Peruana, S. 256.) Cuvier's opinion, that the lama had descended from the still wild Guanaco, has been unfortunately still further disseminated by the meritorious traveller Meyen, (Reise um die Erde, Th. iii. S. 64), but has been completely refuted by von Tschudi.

The Lama, the Paco or Alpaca, and the Guanaco, ar three originally distinct species of animals. (Tschudi, S. 228 and 237.) The Guanaco (Huanacu in the Quichua language) is the largest of the three; and the Alpaca, measured from the ground to the crown of the head, the smallest. The lama is next to the guanaco in stature. Herds of lamas, when they are as numerous as I have seen 
them in the high plateau between Quito and Riobamba, are a great ornament to the landscape. The Moromoro of Chili appears to be a mere variety of the lama. Vicuñas, Guanacoes, and Alpacas, still live wild at elevations of from 13000 to 16000 feet above the level of the sea. The two latter species are sometimes met with tamed, but the guanaco only rarely. The alpaca does not bear the warmer climate of the lower elevations so well as the lama. Since the introduction of the more useful horses, mules, and asses, (the latter acquire great spirit and beauty within the tropics), the custom of rearing and using the lama and the alpaca as beasts of burden, in the mountains and among the mines, has much decreased. But the wool, of such different qualities in respect to fineness, is still an important article in the industry of the inhabitants of the mountains. In Chili the wild and the tamed guanaco are distinguished by separate names; the wild being called Luan, and the tame Chilihueque. The wide dissemination of the wild guanaco, from the Peruvian Cordilleras to Tierra del Fuego, sometimes in herds of 500 , has been favoured by the circumstance that these animals can swim with great ease from island to island, so that the Patagonian fiords offer no obstacle to their wanderings. (See the pleasing descriptions by Darwin in his Journal, 1845, p. 66.)

South of the Gila River, which, together with the Rio Colorado, enters the Californian Gulf or Mar de Cortes, stand, in the solitude of the Steppe, the enigmatical ruins of the Aztec Palace, called by the Spaniards las Casas grandes. When the Aztecs, about the year 1160, came from the un- 
known land of Aztlan to Anahuac, they settled themselves for a time on the banks of the Gila. The Franciscan monks, Garces and Font, are the latest travellers who have visited the Casas grandes, and they did so in 1773. They stated the ruins to extend over above a square German mile (16 English square miles). The whole plain is strewed with fragments of painted pottery. The principal palace, (if a house built of unburnt clay can be so designated), is 447 English feet long and 277 English feet broad. (See a rare work printed in Mexico, and entitled Cronica seráfica y apostólica del Colegio de Propaganda Fide de la Santa Cruz de Querétaro por Fr. Juan Domingo Arricivita).

The Tayé of California, as drawn by Father Venegas, appears to differ little from the Ovis musimon of the Old Continent. The same animal is also seen on the "Stony Mountains," near the sources of the Peace River. Very different from it, on the other hand, is the small white and black spotted goat-like creature which feeds near the Missouri and Arkansas rivers. The synonymy of Antilope furcifer, A. tememazama of Smith, and Ovis montana, is still very undetermined.

\section{$\left.{ }^{(27}\right)$ p. 14.- "The cultivation of farinaceous grasses."}

The original habitat of the farinaceous grasses is wrapped in the same obscurity as that of the domestic animals which have accompanied man since his earliest migrations. The German word for corn, "Getraide," has been ingeniously derived by Jacob Grimm from the old German gitragidi, getregede. "It is as it were the tame fruit (fruges, frumen- 
tum), which has come into the hands of man; as we speak of tame animals in opposition to wild ones." (Jacob Grimm, Gesch. der deutschen Sprache, 1848, Th. i. S. 62.) It is certainly a very striking phenomenon, to find on one side of our planet nations to whom flour or meal from small-eared grasses (Hordeaceæ and Avenaceæ), and the use of milk, were completely unknown, while the nations of almost all parts of the other hemisphere cultivate the Cerealia, and rear milk-yielding animals. The cultivation of different kinds of grasses may be said to afford a characteristic distinction between the two parts of the world. In the New Continent, from $52^{\circ}$ north to $46^{\circ}$ south latitude, we see only one species cultivated, viz. maize. In the Old Continent, on the other hand, we find every where, from the earliest times of history, the fruits of Ceres, wheat, barley, spelt or red wheat, and oats. That wheat grew wild in the Leontine fields, as well as in several other places in Sicily, was a belief entertained by ancient nations, and is mentioned by Diodorus Siculus. (Lib. v. p. 199 and 232, Wessel.) Ceres was found in the alpine meadow of Enna; and Diodorus fables that "the inhabitants of the Atlantis were unacquainted with the fruits of Ceres, because they had separated from the rest of mankind before those fruits had been shewn to mortals." Sprengel has collected several interesting passages which lead him to think it probable that the greater part of our European kinds of grain were originally wild in the northern parts of Persia and India, namely, summer wheat in the country of the Musicanes, a province in Northern India (Strabo, xv. 1017); barley (" anti- 
quissimum frumentum," as Pliny calls it, and which is also the only cereal with which the Guanches of the Canaries were acquainted), according to Moses of Chorene (Geogr, Armen. ed. Whiston, 1736, p. 360), on the Araxes or Kur in Georgia, and according to Marco Polo in Balascham in Northern India (Ramusio, vol. ii. p. 10) ; and spelt or red wheat, near Hamadan. But these passages, as has been shewn by my keen-sighted friend and teacher Link, in an instructive critical memoir (Abhandl. de Berl. Akad. 1816, S. 123), still leave much uncertainty. I also early regarded the existence of originally wild kinds of grain in Asia as extremely doubtful, and viewed such as might have been seen there as having become wild. (Essai sur la Géographie des Plantes, 1805, p. 28.) Reinhold Forster, who before his voyage with Captain Cook, made by order of . the Empress Catherine an expedition into Southern Russia for purposes of natural history, reported that the twostalked summer barley (Hordeum distichon), grew wild near the junction of the Samara and the Volga. At the end of the month of September, 1829, Ehrenberg and myself, on our journey from Orenburg and Uralsk to Saratow and the Caspian, also herborised on the banks of the Samara. We were, indeed, struck with the quantity of wheat and rye plants growing in what might be called a wild state in the uncultivated ground, but the plants did not appear to us to differ from the ordinary cultivated ones. Ehrenberg received from M. Carelin a kind of rye, Secale fragile, gathered on the Kirgis Steppe, and which Marschall von Bieberstein regarded for a time as the original or mother plant of our 
cultivated rye, Secale cereale. Although Olivier and Michaux speak of spelt (Triticum spelta) as growing wild at Hamadan in Persia, Achill Richard does not consider that Michaux's herbarium bears out this statement. Greater confidence is due to the most recent accounts obtained by the unwearied zeal of a highly-informed traveller, Professor Carl Koch. He found much rye (Secale cereale, var. $\beta$, pectinata) in the Pontic Mountains, at elevations of upwards of five or six thousand feet, in places where within the memory of the inhabitants no grain of the kind had ever been cultivated. Koch remarks, that the circumstance is "the more important because with us this grain never pro. pagates itself spontaneously." In the Schirwan parts of the Caucasus, Koch collected a kind of barley which he calls "Hordeum spontaneum," and considers to be the originally wild "Hordeum zeocriton" of Linnæus. (Carl Koch Beitrage zur Flora des Orients, Heft i. S. 139 and 142.)

A negro slave of the great Cortes was the first who cultivated wheat in New Spain. He had found three grains of it amongst the rice which had been brought from Spain for provision for the army. In the Franciscan convent at Quito, I saw preserved as a relic the earthen vessel which had contained the first wheat sowed there by the Franciscan monk Fray Jodoco Rixi, a native of Ghent in Flanders. The first sowing had been made in front of the convent, on what is now the Plazuela de San Francisco, after cutting down the forest which then extended from the foot of the volcano of Pichincha to the spot in question. The monks, who I often visited during my stay at Quito, begged 
me to explain to them the inscription on the earthen vessel, which they thought must contain some mystic reference to the wheat. I read the motto, which was in the old German dialect, and was- "Whoso drinks from me let him not forget his God." I too felt with the monks that this old German drinking vessel was a truly venerable relic. Would that there had been preserved every where in the New Continent the names, not of those who made the earth desolate by bloody conquests, but of those who first intrusted to it these its fruits so early associated with the civilisation of mankind in the Old Continent! In respect generally to the names of the kinds of grain, as bearing on the original affinities of different languages, a high authority has remarked, that " such indications are much more rare in the case of different kinds of grain, and on subjects of agriculture, than on those connected with the care of cattle: herdsmen when dispersed had still much in common, whereas the subsequent cultivators of the soil had to create new words. But the fact that in comparison with the Sanscrit, Romans and Greeks appear nearly on a par with the Germans and Slavonians, argues in favour of the very early contemporaneous emigration of the two latter. Yet the Indian "java” (Frumentum hordeum), eompared with the Lithuanian " jawai," and the Finnish “ jywa,” offers a singular exception.” (Jac. Grimm, Gesch. der deutschen Sprache, Th. i. S. 69.)

\section{$\left.{ }^{28}\right)$ p. 14.- "Keeping by preference to the cooler mountain regions."}

Throughout Mexico and Peru the traces of a great degree 
of civilisation are confined to the elevated plateaux. We have seen on the Andes the ruins of palaces and baths at heights between 1600 and 1800 toises (10230 and 11510 English feet). It can only have been men of a northern race, who, migrating from the north towards the south, could find delight in such a climate.

(29) p. 15.- "The history of the peopling of Japan:"

The probability of the western nations of the New Continent having had communication with the east of Asia long before the arrival of the Spaniards, was I think shewn by me in a work on the monuments of the native inhabitants of America (Vues des Cordillères et Monumens des peuples. indigenes de l'Amérique). I inferred this probability from a comparison of the Mexican and Thibeto-Japanese calendars, -from the correct orientation of the steps of the pyramidal. elevations towards the different quarters of the heavens;and from the ancient myths and traditions of the four ages or four epochs of destruction of the world, and the dispersion of mankind after a great flood of waters. The accounts published since my work, in England, France, and the United States, describing the wonderful bas reliefs, almost in the Indian style, in the ruins of Guatimala and Yucatan, have given to these analogies a still higher value. (Compare Antonio del Rio, Description of the Ruins of an Ancient City discovered near Palenque, 1822, translated from the original manuscript report by Cabrera (del Rio's exploration took place in 1787), p. 9, tab. 12-14; with Stephens, Incidents of Travel in Yucatan, 1843, vol. i. pp. 391 and 429-434; vol. ii. pp. 21, 54, 56, 317, 323; 
with the magnificent volume of Catherwood, "Views of ancient Monuments in Central America, Chiapas, and Yucatan," 1844; and lastly, with Prescott's " Conquest of Mexico," vol. iii. App. p. 360.)

The architectural remains in the peninsula of Yucatan shew, still more than those of Palenque, a degree of civilisation and art which excites our astonishment. They are situated between Valladolid, Merida, and Campeachy, chiefly in the western part of the country. But the monuments in the island of Cozumel (more properly Cuzamil), east of Yucatan, were the first which were seen by the Spaniards in the expedition of Juan de Grijalva, 1518, and that of Cortes in 1519, and the report of them did much to spread over Europe a high idea of ancient Mexican civilisation. The most important ruins of the peninsula of Yucatan, which unfortunately have not yet been thoroughly measured and drawn by architects, are the Casa del Gobernador of Uxmal, the Teocallis and vaulted constructions at Kabah, the ruins of Labnah with domed columns, those of Zayi with columns very nearly of the Doric order, and those of Chiche with large ornamented pilasters. An old manuscript written in the Maya language by a Christian Indian, and which is still in the hands of the Gefe politico of Peto, Don Juan Pia Perez, gives the different epochs ("Katunes" of 52 years) in which the Toltecs settled in different parts of the peninsula. From these data Perez infers that the monuments or buildings of Chiche go back to the close of the fourth century of our era, while those of Uxmal belong to the middle of the tenth century. But the accuracy of these 
conclusions is subject to much uncertainty. (Stephens, Incidents of Travel in Yucatan, vol. i. p. 439; and vol. ii. p. 278.)

I regard the existence of ancient connections between the inhabitants of western America and eastern Asia as more than probable, but by what routes, or with what Asiatic nations, the communications took place, cannot at present be decided. A small number of individuals of the educated priestly caste might perhaps be sufficient to bring about great alterations in the civil and social state of western America. The stories formerly narrated of Chinese expeditions to the New Continent really apply only to voyages to Fusang or Japan. On the other hand, Japanese and Sian-Pi from the Corea may have been driven by storms to the American coast, and landed there. We know as matter of history that Bonzes and other adventurers sailed over the eastern Chinese seas in search of some medicine which should entirely prevent death. Under Tschin-schikuang-ti, 209 years before our era, 300 young couples, young men and young women, were sent to Japan, and instead of returning to China they settled at Nipon (Klaproth, Tableaux historiques de l'Asie, 1824, p. 79; Nouveau Journal Asiatique, T. x. 1832, p. 335; Humboldt, Examen critique, T. ii. p. 62-67). May not similar expeditions have been driven by storms or other accidents to the Aleutian islands, to Alashka, or to New California? As the western coasts of the American continent trend from NW. to SE., and the eastern coasts of Asia in the opposite direction, or from NE. to SW., the distance between the two continents 
in $45^{\circ}$ of latitude, or in the temperate zone which is most favourable to mental development, is too considerable to admit of the probability of such an accidental settlement taking place in that latitude. We must, then, assume the first landing to have been made in the inhospitable climate of from $55^{\circ}$ to $65^{\circ}$, and that the civilisation thus introduced, like the general movement of population in America, has proceeded by successive stations from north to south (Humboldt, Relat. historique, t. iii. p. 155-160). The remains of ships from Cathay, i. e., from Japan or China, were supposed to have been found on the coasts of the northern Dorado, (called Quivira and Cibora) at the beginning of the 16th century (Gomara, Hist. general de las Indias, p. 117).

Our knowledge of the languages of America is still too limited, considering their great variety, for us as yet entirely to relinquish the hope of some day discovering an idiom which may have been spoken, with certain modifications, at once in the interior of South America and in that of Asia; or which may at least indicate an ancient affinity. Such a discovery would certainly be one of the most brilliant. which can be expected in reference to the history of mankind. But analogies of language only deserve confidence when the enquirer, not resting in or dwelling on resemblances of sound in the roots, traces the analogies into the organic structure, the grammatical forms, and into all which in languages shews itself as the product of the human intellect and character. 
$\left.{ }^{(30}\right)$ p. 15.- "Many other forms of animals."

Whole herds of the Cervus mexicanus wander over the Caraccas Steppes: the young stag is spotted, and resembles in appearance the roe-deer of Europe. We saw among them many entirely white, - a singular circumstance in the torrid zone. The Cervus mexicanus is not found at greater elevations on the mountain-slopes of the Andes under the equator than from 700 to 800 toises (4476 to 5115 Eng. feet); but a larger, and also often white, stag,-which I could hardly distinguish from the European by any specific characters, - is met with up to 2000 toises (12789 Eng. feet). The Cavia capybara, called in the province of Caraccas "chiguire," is an unfortunate animal; being pursued in the water by the crocodile, and on the plain by the tiger or jaguar. It runs so badly that we could often catch it with our hands. Its extremities are smoked for hams, but their taste is very disagreeable from the smell of musk; and on the Orinoco we willingly ate monkey hams in preference. The beautifully marked animals which have so disagreable an odour are the Viverra mapurito, Viverra zorilla, and Viverra vittata.

(31) p. 16.-"The Guaranis, and the fan-palm, Mauritia."

The small coast tribe or nation of the Guaranis, (called in British Guiana the Warraws or Guaranos, and by the Caribs U-ara-u), inhabit not only the marshy Delta and 
river network of the Orinoco, and particularly the banks of the Manamo Grande and the Caño Macareo, but also extend, with little variation in their modes of life, along the sea coast between the mouths of the Essequibo and the Boca de Navios of the Orinoco. (Compare my Relation historique, T. i. p. 492, T. ii. p. 653 and 703, with Richard Schomburgk's "Reisen in Britisch Guiana," Th. i. 1847 , S. $62,120,173$, and 194). According to the testimony of the last-named excellent explorer and observer, there are still 1700 Warraus or Guaranis living in the district of Cumaca, and along the banks of the Barima river, which empties itself into the gulf of the Boca de Navios. The manners and customs of the tribes living in the Delta of the Orinoco were already known to the great historical writer Cardinal Bembo, the contemporary of Columbus, Amerigo Vespucci, and Alonzo de Hojeda. He says, "quibusdam in locis propter paludes incolæ domus in arboribus ædificant” (Historiæ Venetæ, 1551, p. 88). It is more probable that Bembo is alluding to the Guaranis at the mouth of the Orinoco, than to the natives near the mouth of the Gulph of Macaraibo, where Alonzo de Hojeda, in August 1499, when he was accompanied by Vespucci and Juan de la Cosa, also found a population having their residence "fondata sopra l' acqua come Venezia" (Riccardi's Text in my Examen crit. t. iv. p. 496). In Vespucci's account of his voyage (in which we find the first indication of the etymology of the term Province of Venezuela, Little Venice, for Province of Caraccas), he 
only speaks of houses raised upon foundation pillars, not of habitations in the trees.

Sir Walter Raleigh offers a later evidence of high authority; he says expressly, in his descrijtion of Guiana, that on his second voyage in 1595, when in the mouth of the Orinoco, he saw the "fires" of the Tivitives and the Oua-raa-etes (so he calls the Guaranis) " high up in the trees" (Raleigh, Discov. of Guiana, 1596, p. 90). The fire is represented in a drawing in the Latin edition : "brevis et admiranda descriptio regni Guianæ," (Norib. 1599) tab. 4. Raleigh was also the first who brought to England the fruit of the Mauritia-palm, which he very justly compared, on account of its scales, to a fir cone. The Padre José Gumilla, who twice visited the Guaranis as a missionary, says, indeed, that this people had their habitation in the palmares (palm groves) of the morasses; but he only mentions dwellings raised upon high pillars, and not scaffoldings attached to trees still in a growing state; (Gumilla, Historia natural, civil, y geografica de las Naciones situadas en las riveras del Rio Orinoco, nueva imp. 1791, p. 143, 145, and 163). Hillhouse and Sir Robert Schomburgk, (Journal of the Royal Geographical Society, vol. xii. 1842, p. 175; and Description of the Murichi or Ita Palm, read at the Meeting of the British Association held at Cambridge, June 1845; printed in Simond's Colonial Magazine), are of opinion that both Bembo and Raleigh, (the former speaking from the reports of others, the latter as an eyewitness), were deceived by the high tops of the palm-trees 
being lit up at night by the flames of fires beneath, so that those who sailed by thought the habitations themselves were attached to the trees. "We do not deny that in order to escape the attacks of the musquitos, the Indian sometimes suspends his hammock from the tops of trees; on such occasions, however, no fires are made under the hammock." (Compare also Sir Robert Schomburgk's New Edition of Raleigh's Discovery of Guiana, 1848, p. 50.)

According to Martius, the fine Palm Moriche, Mauritia flexuosa, Quiteve, or Ita palm, (Bernau, Missionary Labours in British Guiana, 1847, p. 34 and 44), belongs, as well as Calamus, to the group of Lepidocaryeæ or Coryphineæ. Linnæus has described it very imperfectly, as he erroneously considers it to be leafless. The trunk grows as high as 26 feet, but it probably requires from 120 to 150 years to reach this height. The Mauritia extends high up on the declivity of the Duida, north of the Esmeralda mission, where I have found it in great beauty. It forms in moist places fine groups of a fresh shining verdure, which reminds us of that of our Alder groves. The trees preserve the moisture of the ground by their shade, and hence the Indians say that the Mauritia draws the water round its roots by a mysterious attraction. By a somewhat similar theory they advise that serpents should not be killed; because the destruction of the serpents and the drying up of the pools or lagunas accompany each other: thus the untutored child of nature confounds cause and effect. Gumilla terms the Mauritia flexuosa of the Guaranis the tree of life, arbol de la vida. It grows in the mountains of Ronaima, 
east of the sources of the Orinoco, as high as $4000(4263$ Eng.) feet. On the unvisited banks of the Rio Atabapo, in the interior of Guiana, we discovered a new species of Mauritia with prickly stems, our Mauritia aculeata; (Humboldt, Bonpland and Kunth, Nova Genera et Species Plantarum, t. i. p. 310).

(32) p. 16.-“An American Stylites."

The founder of the sect of the Stylites, the fanatical pillar-saint Simeon Sisanites, the son of a Syrian herdsman, is said to have passed thirty-seven years in religious contemplation on the summits of five successive pillars, each higher than the preceding. The last pillar was 40 ells high. He died in the year 461. For seven hundred years there continued to be men who imitated this manner of life, and were called "sancti columnares" (pillar saints). Even in Germany, in the Diocese of Treves, it was proposed to erect such aerial cloisters, but the Bishops opposed the undertaking (Mosheim, Institut. Hist.Eccles. 1755, p. 215.)

\section{(33) p. 17.- "Towns on the banks of the streams which flow through the Steppe."}

Families who live not by agriculture but by the care of cattle, have congregated in the middle of the Steppe in small towns, which, in the cultivated parts of Europe, would hardly be regarded as villages. Such are Calabozo, in $8^{\circ} 56^{\prime} 14^{\prime \prime} \mathrm{N}$. lat. and $67^{\circ} 42^{\prime}$ long. according to my observations, Villa del Pao, lat $8^{\circ} 38^{\prime} 1^{\prime \prime}$, long. $66^{\circ} 57^{\prime}$, S. Sebastian, and others. 


\section{(34) p. 17.- "Conical-shaped clouds."}

The singular phenomenon of these "sand spouts,"something analogous to which may occasionally be seen on a small scale in Europe where four roads meet,-is particularly characteristic of the Peruvian Sand Desert between Amotape and Coquimbo. Such a dense cloud of sand or dust may prove dangerous to the traveller who does not cautiously avoid its approach. It is also worthy of notice that these partial conflicting currents of air only arise when the air generally is perfectly calm. The aerial ocean resembles the sea in this respect, for in the latter also the small currents which are often heard to ripple audibly, (filets de courant), are only perceptible in a dead calm (calme plat).

\section{$\left.{ }^{(35}\right)$ p. 18.- "Increases the suffocating heat."}

I have observed in the Llanos de Apure, at the Guadalupe cattle farm, the thermometer rise from $27^{\circ}$ to $29^{\circ}$ Reaumur $\left(92^{\circ} .7\right.$ to $97^{\circ} .2$ Fahr.) whenever the hot wind began to blow from the Desert, which at such times was covered either with sand or with short withered turf. In the middle of the sand-cloud the temperature was for some minutes $35^{\circ} \mathrm{R} .\left(111^{\circ} \mathrm{F}\right.$.). The dry sand in the village of San Fernando de Apure had a temperature of $42^{\circ} \mathrm{R}$. (126 ${ }^{\circ}$ Fahr.)

${ }^{(36}$ ) p. 18. - "The illusive image of a cool rippling watery mirror."

The well-known phenomenon of the mirage is called in 
Sanscrit the "thirst of the gazelle." (See my Relation historique, T. i. pp. 296 and 625 ; T. ii. p. 161.) All objects appear to hover in the air, and are at the same time seen reflected in the lower stratum of air. At such times the entire desert assumes the aspect of the wave-covered surface of a wide spread lake. Palm trees, cattle, and camels, sometimes appear inverted on the horizon. In the French expedition to Egypt, the soldiers, parched with thirst, were often brought by this optical illusion into a state of desperation. This phenomenon has been remarked - in all quarters of the globe. The ancients were acquainted with the remarkable refraction of the rays of light in the Lybian Desert. I find mention made in Diod. Sic. lib. iii. p. 184, Rhod. (p. 219, Wessel), of extraordinary illusive images, an African Fata Morgana, with most extravagant explanations of the supposed conglomeration of the particles of air.

\section{(37) p. 19.—"The Melon-Cactus."}

The Cactus melo cactus is often 10 to 12 inches in diameter, and has usually 14 ribs. The natural group of Cactaceæ, the whole family of Nopaleæ of Jussien, belong exclusively to the New Continent. The cactuses assume a great variety of shapes : ribbed and melon-like (Melo cacti) ; articulated or jointed (Opuntiæ); forming upright columns or pillars (Cerei); serpentine and creeping (Rhipsalides); or provided with leaves (Pereskiæ). Many extend high up the sides of the mountains. Near the foot of the Chimborazo, in the elevated sandy plain around Riobamba, I have found a new kind of Pitahaya, the Cactus sepium, even at a height 
of 10,000 (10,660 Eng.) feet. (Humboldt, Bonpland, and Kunth, Synopsis Plantarum æquinoct. Orbis novi, T. iii. p. 370).

(38) p. 19.- "The scene in the Steppe is suddenly changed."

I have endeavoured to depict the coming in of the rainy season, and the signs by which it is announced. The usual deep dark azure of the sky in the tropics arises from the more complete solution of the vapour contained in the atmosphere. The cyanometer indicates a paler blue as soon as the vapours begin to be precipitated. The dark spot or patch in the constellation of the Southern Cross gradually becomes indistinct as the transparency of the atmosphere diminishes, and this alteration announces the near approach of rain. The brightness of the Magellanic clouds, (Nubecula major and minor), gradually vanishes in a similar manner. The fixed stars, which before shone like planets with a steady, tranquil, and not trembling light, now scintillate even in the zenith, where the vapours are least. (See Arago, in my Relation hist. T. i. p. 623). All these appear. ances are the results of the increased quantity of vapour diffused in the atmosphere.

(39) p. 20.- "Awakened from a torpid state by the first fall of rain."

Extreme dryness produces in plants and animals the same phenomena as does the withdrawal of the stimulus of heat. Many tropical trees and plants shed their leaves during the dry 
season. The crocodiles and other amphibious animals hide themselves in the mud, where they lie apparently dead, like animals in a state of hybernation or plunged into winter sleep by cold. (See my Relation historique, T. ii. pp. 192 and 626.)

$\left.{ }^{40}\right)$ p. 20.- "The aspect of a vast inland sea."

Nowhere are these inundations more extensive than in the network of rivers formed by the Apure, the Arachuna, Pajara, Arauca, and Cabuliare. Large vessels sail across the country over the Steppe for 40 or 50 miles.

(41) p. 21. - "To the mountain plateau of Antisana."

The great mountain plain or plateau surrounding the volcano of Antisana is 2107 toises (13473 English feet), above the level of the sea. The atmospheric pressure at this elevation is so small that the wild cattle, when hunted with dogs, bleed from the nose and mouth.

$$
\text { (42) p. 22.- "Bera and Rastro." }
$$

I have described the capture of the Gymnoti in detail in another place. (Observations de Zoologie et d'Anatomie comparée, vol. i. p. 83-87; and Relation historique, T. ii. p. 173-190). M. Gay Lussac and I found the experiment without a circuit succeed perfectly with a living Gymnotus, which was still very vigorous when brought to Paris. The discharge is solely dependent on the will of the animal. 
We did not see any spark, but other physicists have done so on several occasions.

\section{$\left.{ }^{(43}\right)$ p. 23.- "Awakened by the contact of moist dissimilar particles."}

In all parts of organic bodies dissimilar substances are in contact with each other: in all, solids are associated with fluids. Thus, wherever there is organization and life, there is also electric tension or the play of the voltaic pile, as the experiments of Nobili and Matteucci, and especially the latest admirable labours of Emil du Bois, teach us. The last named physicist has succeeded in "manifesting the presence of the electric muscular current in living and wholly uninjured animal bodies:" he shews that "the human body, through the medium of a copper wire, can canse a magnetic needle at a distance to be deflected at pleasure, first in one and then in the opposite direction." (Untersuchungen über thierische Electricetät, von Emil du Bois-Reymond, 1848, Bd. i. S. xv.) I have witnessed these movements produced at pleasure, and have had the gratification of seeing thereby great and unexpected light thrown on phenomena to which I had laboriously and hopefully devoted several years of my youth.

\section{(44) p. 23.- "Osiris and Typhon."}

On the conflict between two races of men, the Arabian pastoral people in Lower Egypt, and the agricultural race in Upper Egypt who were in a more advanced state of civilisation, on the fair-haired Prince Baby or Typhon, who founded 
Pelusium, and on the dark-complexioned Dionysos or Osiris, see Zoëga's ancient, and now for the most part abandoned views, in his great work "De Origine et Usu Obeliscorum," p. 577.

$\left.{ }^{(55}\right)$ p. 24.- "The boundary of a partial European cultivation?"

In the Capitania general de Caracas, as generally every where on the eastern shores of America, the cultivation introduced by Europeans, and their presence and influence, are limited to a narrow strip of country along the coast. In Mexico, New Granada, and Quito, on the other hand, European civilisation has penetrated deep into the interior of the country, and advanced up the ridges of the Cordilleras. There existed in these last-named regions a considerable degree of settled and civilised life previous to the arrival of the Spaniards ; and they have followed this civilisation wherever they found it, regardless whether its seat was near or at a distance from the sea coast. They retained and enlarged the ancient cities, of which they either mutilated the old significant Indian names, or gave them new names, as, for example, of Christian saints.

$\left.{ }^{(46}\right)$ p. 24.- “ Massive leaden-coloured granite rocks."

In the Orinoco, and more especially at the Cataracts of Maypures and Atures, all blocks of granite, and even white pieces of quartz, whenever they are touched by the water of the river, acquire a greyish-black coating which scarcely penetrates a hundredth of a line below the surface of the rock. 
The appearance produced is that of basalt, or fossils coloured with graphite. The crust appears to contain manganese and carbon; I say appears, for the phenomenon has not yet been thoroughly examined. Something similar was remarked by Rozier on the syenite rocks of the Nile, near Syene and Philæ; by the unfortunate Captain Tuckey on the rocky banks of the Congo; and by Sir Robert Schomburgh on the Berbice. (Reisen in Guiana und am Orinoko, S. 212.) On the Orinoco these leaden-coloured rocks are considered to give out pernicious exhalations when wet; and their proximity is believed to produce fevers. (Rel. hist. T. ii. p. 299-304.) In the Rio Negro, and generally in the South American rivers which have "black waters," "aguas negras," or waters of a coffee-brown or yellow tint, no such effects tagke place. No black colour is imparted to the granite rocks by the waters ; that is to say, they do not act upon the stone so as to form from its constituent particles a black or leaden-coloured crust.

(47) p. 24.- "The rain-announcing howlings of the bearded apes."

The melancholy howlings of the small apes, Simia seniculus, Simia beelzebub, \&c., are heard some hours before the rain commences: it is as if the tempest were heard raging at a distance. The intensity of the noise produced by such small animals can only be explained by their number; seventy or eighty being often lodged in a single tree. On the organs of voice of these animals, see my anatomical treatise in the first chapter of my Recueil d'Observations de Zoologie, vol. i. p. 18. 
(48) p. 24.- " Often covered with birds."

The crocodiles lie so motionless that I have seen flamingos (Phœnicopterus) resting on their heads; the body at the same time being covered with aquatic birds, like the trunk of a tree.

\section{$\left.{ }^{49}\right)$ p. 24.- "Down his swelling throat."}

The saliva with which the boa covers his prey hastens the process of decomposition; the muscular flesh thus becomes softened into such a gelatinous state, that he can force entire limbs of larger, and bodies of smaller, animals down his throat without division. The Creoles call this gigantic serpent from these circumstances, "Tragavenado," which means "Stag swallower :", they tell fabulous stories of snakes being seen with the antlers of a stag (which it was impossible to swallow) sticking in their throats. I have several times seen the boa swimming in the Orinoco, and in the smaller forest streams, the Tuamini, the Temi and the Atabapo. It holds its head above the water like a dog. Its skin is finely spotted. It is said to attain a length of 4.8 feet; but the largest skins which have as yet been brought to Europe and carefully measured do not exceed 21 to 23 feet. The South American boa (which is a Python) differs from the East Indian. On the Ethiopian boa, see Diodor. lib. iii. p. 204, ed. Wesseling.

$\left.{ }^{50}\right)$ p. 25.- "Using ants, gums, and earth as food."

It was a very prevalent report on the coasts of Cumana, New Barcelona, and Caraccas, visited by the Franciscan 
monks of Guiana on their return from the missions, that there were men on the banks of the Orinoco who ate earth: When, in returning from the Rio Negro, we descended the Orinoco in thirty-six days, we passed the day of the 6 th of June, $1 \times 00$, in the Mission inhabited by the earth-eating Otomacs. This little village is called $\mathrm{La}$ Concepcion de Uruana, and is very picturesquely situated at the foot of a granite rock. I found its geographical position to be $7^{\circ} 8^{\prime} 3^{\prime \prime} \mathrm{N}$. lat., and $67^{\circ} 18^{\prime} \mathrm{W}$. long. from Greenwich. The earth which the Otomacs eat is a soft unctuous clay; a true potter's clay, of a yellowish-grey colour due to a little oxide of iron. They seek for it in particular spots on the banks of the Orinoco and the Meta, and select it with care. They distinguish the taste of one kind of earth from that of another, and do not consider all clays as equally agreeable to eat. They knead the earth into balls of about five or six inches diameter, which they burn or roast by a weak fire until the outside assumes a reddish tint. The balls are remoistened when about to be eaten. These Indians are generally wild uncultivated beings, and altogether averse to any kind of tillage. It is a proverb even among the most distant of the nations living on the Orinoco, when speaking of anything very unclean, to say that it is "so dirty, that the Otomacs eat it."

As long as the waters of the Orinoco and the Meta are low these Indians live on fish and river tortoises. They kill the fish with arrows when at the surface of the water, a pursuit in which we have often admired their great dexterity. During the periodical swelling of the rivers the taking 
of fish ceases, for it is as difficult to fish in deep river water as in the deep sea. It is in this interval, which is of two or three months' duration, that the Otomacs swallow great quantities of earth. We have found considerable stores of it in their huts, the clay balls being piled together in pyramidal heaps. The very intelligent monk, Fray Ramon Buèno, a native of Madrid (who lived twelve years among these Indians), assured us that one of them would eat from three quarters of a pound to a pound and a quarter in a day. According to the accounts which the Otomacs themselves give, this earth forms their principal subsistence during the rainy season, though they eat at the same time occasionally, when they can obtain it, a lizard, a small fish, or a fern root. They have such a predilection for the clay, that even in the dry season, when they can obtain plenty of fish, they eat a little earth after their meals every day as a kind of dainty. These men have a dark copper-brown complexion, and unpleasing Tartar features. They are fat, but not large-bellied. The Franciscan monk who lived among them as a misssionary, assured us that he could perceive no alteration in their health during the earth-eating season.

The simple facts are therefore as follows :-The Indians eat large quantities of earth without injury to their health; and they themselves regard the earth so eaten as an alimentary substance, i.e. they feel themselves satisfied by eating it, and that for a considerable time; and they attribute this to the earth or clay, and not to the other scanty articles of subsistence which they now and then obtain in addition. If you 
inquire from an Otomac about his winter provision, (in tropical South America the rainy season is usually called winter), he points to the heap of clay balls stored in his hut. But these simple facts by no means determine the questions, whether the clay be really an alimentary substance? whether earths be capable of assimilation? or whether they merely serve to appease hunger by distending the stomach? I cannot pretend to decide these questions. (Rel. hist. T. ii. p. 618-620.) It is curious that the usually credulous and uncritical Father Gumilla positively denies the earth-eating as such. (Historia del Rio Orinoco, nueva impr. 1791, T. i. p. 179.) He affirms that the balls of clay had maizemeal and crocodile-fat mixed with them. But the missionary, Fray Ramon Bueno, and our friend and travelling companion, the lay brother Fray Juan Gonzalez, who was lost at sea off the Coast of Africa with part of our collections, both assured us that the Otomacs never mix crocodile fat with the clay; and of the meal said to be mixed with it we heard absolutely nothing during our stay in Uruana. The earth which we brought back with us, and which Vauquelin analysed, is thoroughly pure and unmixed. May Gumilla, by a confusion of things wholly distinct, have been alluding to the preparation of bread from the long pod of a kind of Inga, which is previously buried in the earth in order to hasten the commencement of the first stage of decay? That the health of the Otomacs should not suffer from eating so much earth appears to me particularly remarkable. Have they become accustomed to it in the course of several generations?

VOL. I. 
In all tropical countries, human beings shew an extraordinary and almost irresistible desire to swallow earth; and not alkaline earths, which they might be supposed to crave to neutralize acid, but unctuous and strong-smelling clays. It is often necessary to confine children to prevent them from running out to eat earth immediately after a fall of rain. I have observed with astonishment the Indian women in the village of Banco on the Magdalena River, whilstengaged inshaping earthen vessels on the potter's wheel, put great lumps of clay into their mouths. The same thing was remarked at an earlier period by Gili. (Saggio di Storia Americana, T. ii. p. 311.) Wolves also eat earth, and especially clay, in winter. It would be important to examine carefully the excrements of animals and men that eat earth. With the exception of the Otomacs, individuals of all other races who indulge for any length of time the strange desire of earth-eating have their health injured by it. At the mission of San Borja, we saw the child of an Indian woman, who, his mother said, would hardly eat anything but earth. He was, however, wasted nearly to a skeleton.

Why is it that in the temperate and cold zones this morbid craving for eating earth is so much more rare, and is almost entirely confined, when it is met with, to children and pregnant women; while in the tropics it would appear to be indigenous in all quarters of the globe? In Guinea the negroes eat a yellowish earth, which they call Caouac. When brought as slaves to the West Indies, they try to obtain a similar earth, and affirm that in their own country 
the habit never did them any harm. In the American Islands they were made ill by it, and it was forbidden in consequence; but a kind of earth (un tuf rouge jaunâtre) was, in 1751, sold secretly in the market in Martinique. "Les negres de Guinée disent que dans leur pays ils mangent habituellement une certaine terre, dont le goût leur plait, sans en être incommodés. Ceux qui sont dans l'abus de manger du Caouac en sont si friands qu'il n'y a pas de châtiment qui puisse les empêcher de dévorer de la terre.” (Thibault de Chanvalon, Voyage à la Martinique, p. 85.) In the Island of Java, between Sarabaya and Samarang, Labillardière saw small square reddish-coloured cakes exposed for sale in the villages. The natives called them tana ampo (tanah, in Malay and Javanese, signifies earth). On examination and enquiry he found that the cakes consisted of reddish clay, and that they were eaten. (Voyage à la Récherche de la Pérouse, T. ii. p. 322.) The edible clay of Samarang has recently been sent to Berlin by Mohnike, in 1847, in the shape of rolled tubes, like cinnamon, and has been examined by Ehrenberg. It is a fresh-water formation deposited on limestone, and consisting of microscopic Polygastrica, Gaillonella, Naviculas, and Phytolitharia. (Bericht über die Verhandl. der Akad. d. Wiss. zu Berlin, aus dem J. 1848, S. 222-225.) The inhabitants of New Caledonia, to appease their hunger, eat pieces as big as the fist of friable steatite, which Vauquelin found to contain in addition no inconsiderable quantity of copper. (Voyage à la Récherche de la Pérouse, T. ii. p. 205.) In Popayan, and several parts of Peru, calcareous earth is sold in the 
streets as an eatable for the Indians; it is used with Coca (the leaves of the Erythroxylon peruvianum.) Thus we find the practice of eating earth diffused throughout the torrid zone, among indolent races inhabiting the finest and most fertile parts of the globe. But accounts have also come from the North, through Berzelius and Retzius, according to which, hundreds of cartloads of earth containing Infusoria are said to be annually consumed by the country people, in the most remote parts of Sweden, as breadmeal, and even more from fancy (like the smoking of tobacco) than from necessity! In Finland this kind of earth is occasionally mixed with the bread. It consists of empty shells of animalculæ, so small and soft that they do not crunch perceptibly between the teeth; it fills the stomach, but gives no real nourishment. In periods of war, chronicles and documents preserved in archives often give intimation of earths containing infusoria having been eaten; speaking of them under the vague and general name of "mountain meal." It was thus during the Thirty Years' War in Pomerania (at Camin); in the Lausitz (at Muskau); and in the territory of Dessau (at Klieken); and subsequently in 1719 and 1733 at the fortress of Wittenberg. (See Ehrenberg über das unsichtbar wirkende organische Leben, 1842, S. 41.)

\section{(51) p. 25.—" Figures graven on the rock."}

In the interior of South America, between the $2 d$ and 4th degrees of North latitude, a forest-covered plain is enclosed by four rivers, the Orinoco, the Atabapo, the Rio 
Negro, and the Cassiquiare. In this district are found rocks of granite and of syenite, covered, like those of Caicara and Uruana, with colossal symbolical figures of crocodiles and tigers, and drawings of household utensils, and of the sun and moon. At the present time this remote corner of the earth is entirely without human inhabitants, throughout an extent of more than 8000 square geographical miles. The tribes nearest to its boundaries are wandering naked savages, in the lowest stage of human existence, and far removed from any thoughts of carving hieroglyphics on rocks. One may trace in South America an entire zone, extending through more than eight degrees of longitude, of rocks so ornamented; viz. from the Rupuniri, Essequibo, and the mountains of Pacaraima, to the banks of the Orinoco and of the Yupura. These carvings may belong to very different epochs, for Sir Robert Schomburgk even found on the Rio Negro representations of a Spanish galiot (Reisen in Guiana und am Orinoko, übersetzt von Otto Schomburgk, 1841, S. 500), which must have been of a later date than the beginning of the 16th century; and this in a wilderness where the natives were probably as rude then as at the present time. But it must not be forgotten that, as I have elsewhere noticed, nations of very different descent, when in a similar uncivilized state, having the same disposition to simplify and generalise outlines, and being impelled by inherent mental dispositions to form rhythmical repetitions and series, may be led to produce similar signs and symbols. (Compare Relation hist. T. ii. p. 589, and Martius uber die Physionomie des Pflanzenreichs in Brasilien, 1824, S. 14.) 
At the Meeting of the Society of Antiquaries of London, on the 17th of November, 1836, there was read a memoir by Sir Robert Schomburgk "On the Religious Traditions of the Macusi Indians, who inhabit the Upper Mahu and a part of the Pacaraima Mountains ;" a nation, consequently, who for a century (since the journey of the adventurous Hortsmann,) have not changed their residence. Sir Robert Schomburgk says: "The Macusis believe that the sole survivor of a general deluge repeopled the earth by changing stones into human beings." This myth (the fruit of the lively imagination of these nations, and which reminds us of Deucalion and Pyrrha), shews itself in a somewhat altered form among the Tamanaks of the Orinoco. When asked how mankind survived the great flood, the "age of waters" of the Mexicans, they reply without any hesitation, that 'one man and one woman took refuge on the high mountain of Tamanacu, on the banks of the Asiveru, and that they then threw over their heads and behind their backs the fruits of the Mauritia-palm, from the kernels of which sprang men and women who repeopled the earth.' Some miles from Encaramada, there rises, in the middle of the savannah, the rock Tepu-Mereme, or the painted rock. It shews several figures of animals and symbolical outlines which resemble much those observed by us at some distance above Encaramada, near Caycara, in $7^{\circ} 5^{\prime}$ to $7^{\circ} 40^{\prime}$ lat. and $66^{\circ} 28^{\prime}$ to $67^{\circ} 23^{\prime} \mathrm{W}$. long. from Greenwich. Rocks thus marked are found between the Cassiquiare and the Atabapo (in $2^{\circ} 5^{\prime}$ to $3^{\circ} 20^{\prime}$ lat.), and what is particularly remarkable, 560 geographical miles farther to the East in the solitudes of the Parime. This last fact is placed beyond a 
donbt by the journal of Nicholas Hortsman, of which I have seen a copy in the handwriting of the celebrated D'Anville. That simple and modest traveller wrote down every day, on the spot, what had appeared to him most worthy of notice, and he deserves perhaps the more credence because, being full of dissatisfaction at having failed to discover the objects of his researches, the Lake of Dorado, with lumps of gold and a diamond mine, he looked with a certain degree of contempt on whatever fell in his way. He found, on the 16th of April, 1749, on the banks of the Rupunuri, at the spot where the river winding between the Macarana mountains forms several small cascades, and before arriving in the district immediately round Lake Amucu, "rocks covered with figures," - or as he says in Portuguese, "de varias letras." We were shown at the rock of Culimacari, on the banks of the Cassiquiare, signs which were called characters, arranged in lines,--but they were only ill-shaped figures of heavenly bodies, boa-serpents, and the utensils employed in preparing manioc-meal. I have never found among these painted rocks (piedras pintadas) any symmetrical arrangement or any regular even-spaced characters. I am therefore disposed to think that the word "letras" in Hortsmann's journal must not be taken in the strictest sense.

Schomburgk was not so fortunate as to rediscover the rock seen by Hortsmann, but he has seen and described others on the banks of the Essequibo, near the cascade of Warraputa. "This cascade," he says, "is celebrated not only for its height but also for the quantity of figures cut on the rock, which have great resemblance to those which I have seen in the Island of St. John, one of the Virgin 
Islands, and which I consider to be, without doubt, the work of the Caribs, by whom that part of the Antilles was formerly inhabited. I made the utmost efforts to detach portions of the rock which contained the inscription, and which I desired to take with me; but the stone was too hard, and fever had taken away my strength. Neither promises nor threats could prevail on the Indians to give a single blow with a hammer to these rocks, - the venerable monuments of the superior mental cultivation of their predecessors. They regard them as the work of the Great Spirit, and the different tribes who we met with, though living at a great distance, were nevertheless acquainted with them. Terror was painted on the faces of my Indian companions, who appeared to expect every moment that the fire of heaven would fall on my head. I saw clearly that my endeavours would be fruitless, and I contented myself with bringing away a complete drawing of these memorials." The last determination was certainly the best, and the editor of the English Journal, to my great satisfaction, adds a note to the effect that it is to be wished that no one else may be more successful than Mr. Schomburgk, and that no future traveller from civilized countries may do anything towards the destruction of these monuments of the unprotected Indians.

The symbolical signs seen by Robert Schomburgk in the Valley of the Essequibo, near the rapids of Waraputa, (Richard Schomburgk, Reisen in Britisch-Guiana, Th. i. S. 320), were remarked by him to bear a great resemblance to genuine Carib ones in one of the small Virgin Islands (St. John's); but notwithstanding the wide 
extent of the invasions of the Caribs, and the ancient power of this fine race, I cannot believe that all the rock engravings,-which, as I have said, form an immense belt traversing a great part of South America from west to east,-are to be regarded as their work. I am inclined rather to view these remains as traces of an ancient civilisation,-belonging, perhaps, to an epoch when the tribes whom we now distinguish by various appellations were still unknown. Even the veneration everywhere testified by the Indians of the present day for these rude sculptures of their predecessors, shews that they have no idea of the execution of similar works. There is another circumstance which should be mentioned: between Encaramada and Caycara, on the banks of the Orinoco, a number of these hieroglyphical figures are sculptured on the face of precipices at a height which could now be reached only by means of extraordinarily high scaffolding. If one asks the natives how these figures can have been cut, they answer, laughing, as if it were a fact of which none but a white man could be ignorant, that "in the days of the great waters their fathers went in canoes at that height." Thus a geological fancy is made to afford an answer to the problem presented by a civilisation which has long passed away.

Let me be permitted to introduce here a remark which I borrow from a letter addressed to me by the distinguished traveller, Sir Robert Schomburgk. "The hieroglyphical figures are more widely extended than you had perhaps supposed. During my expedition, which had 
for its object the examination of the Corentyn River, I not only observed some colossal figures on the rock of Timeri (4 $\frac{1}{2}^{\circ} \mathrm{N}$. lat. and $57 \frac{1}{2}^{\circ} \mathrm{W}$. long.), but I also discovered similar ones near the great cataracts of the Corentyn, in $4^{\circ} 21^{\prime} 30^{\prime \prime} \mathrm{N}$. lat. and $57^{\circ} 55^{\prime} 30^{\prime \prime} \mathrm{W}$. long. These figures are executed with much greater care than any which I discovered in Guiana. Their size is about ten feet, and they appear to represent human figures. The head-dress is extremely remarkable; it encompasses the head, spreading out considerably in breadth, and is not unlike the halos represented in paintings as surrounding the heads of Saints and Sacred Persons. I have left my drawings of these figures in the colony, but I hope some day to be able to lay them all before the public. I saw ruder figures on the Cuyuwini, a river which empties itself into the Essequibo in latitude $2^{\circ} 16^{\prime} \mathrm{N}$., entering it from the north-west; and I have since seen similar figures on the Essequibo itself in $1^{\circ} 40^{\prime} \mathrm{N}$. lat. These figures extend, therefore, as ascertained by actual observation, from $7^{\circ} 10^{\prime}$ to $1^{\circ} 40^{\prime} \mathrm{N}$. lat., and from $57^{\circ} 30^{\prime}$ to $66^{\circ} 30^{\prime} \mathrm{W}$. long. Thus the zone of pictured rocks extends, so far as it has been at present examined, over a space of 192000 square geographical miles, comprising the basins of the Corentyn, the Essequibo, and the Orinoco; a circumstance from which we may form some inferences respecting the former amount of population in this part of the continent."

Other remarkable remains of a degree of civilisation which no longer exists, are the granite vases with graceful labyrinthine ornaments, and the earthen masks resembling Roman 
ones, which have been discovered on the Mosquito coast, among wild Indians. (Archæologia Britan. vol. v. 1779, p. 318-324; and vol. vi. 1782, p. 107.) I have had them engraved in the "Picturesque Atlas" which accompanies the historical portion of my Travels to the Equinoctial Regions. Antiquaries are astonished at the similarity of these ornaments (resembling a well-known Grecian form), to those of the Palace of Mitla, near Oaxaca, in Mexico. In looking at Peruvian carvings, I have never remarked any figures of the large-nosed race of men, so frequently represented in the basreliefs of Palenque in Guatimala, and in the Aztec paintings. Klaproth remembered having seen individuals with similar large noses among the Chalcas, a northern Mogul tribe. It is well known that many tribes of the North American red or copper-coloured Indians have fine aquiline noses ; and that this is an essential physiognomic distinction between them and the present inhabitants of Mexico, New Granada, Quito, and Peru. Are the large-eyed, comparatively fair-complexioned people, spoken of by Marchand as having been seen in $54^{\circ}$ and $58^{\circ}$ lat. on the north-west coast of America, descended from an Alano-Gothic race, the Usüni of the interior of Asia?

${ }^{(52)}$ p. 25.- "Apparently weaponless, and yet prepared for murder."

The Otomacs often poison the thumb-nail with Curare. A mere scratch of the nail is deadly if the curare mixes with the blood. We obtained specimens of the climbing plant, from the juice of which the curare is prepared, at 
Esmeralda on the Upper Orinoco, but unfortunately we did not find it in blossom. Judging by its physiognomy it appears to be related to Strychnos (Rel. hist. T. ii. p. 547556). Since the notice in the work referred to of the curare or ourari (previously mentioned by Raleigh, both as a plant and as a poison), the brothers Robert and Richard Schomburgk have done much towards making us accurately acquainted with the nature and preparation of this substance, of which I was the first to bring a considerable quantity to Europe. Richard Schomburgk found the plant in blossom in Guiana on the banks of the Pomeroon and the Sururu in the territory of the Caribs, who are not, however, acquainted with the manner of preparing the poison. His instructive work (Reisen in Britisch-Guiana, Th. i. S. 441461), contains the chemical analysis of the juice of the Strychnos toxifera, which, notwithstanding its name and its organic structure, does not contain, according to Boussingault, any trace of strychnine. Virchou and Münter's interesting physiological experiments make it probable that the curare or ourari poison does not kill by mere external absorption, but only when absorbed by living animal substance of which the continuity has been severed $(i . e$. which has been wounded slightly); that it does not belong to the class of tetanic poisons; and that its particular effect is to take away the power of voluntary muscular movement, whilst the involuntary functions of the heart and intestines still continue. Compare, also, the older chemical analysis of Boussingault, in the Annales de Chimie et de Physique, T. xxxix. 1828, p. 24-37. 
THE

CATARACTS OF THE ORINOCO. 


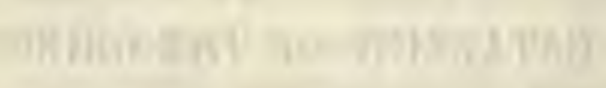


THE

\section{CATARACTS OF THE ORINOCO.}

Iv the preceding section, which was made the subject of an academical lecture, I sought to depict those boundless plains which, according to the varying modification of their natural characters induced by climatic relations, appear to us sometimes as Deserts devoid of vegetation, and sometimes as Steppes, or widely-extended grassy plains or Prairies. In so doing I contrasted the Llanos of the southern part of the New Continent with the dreadful seas of sand which form the African Deserts; and these again with the Steppes of Central Asia, the habitation of world-assailing pastoral nations, who at a former period, when pressed hitherward from the East, spread barbarism and devastation over the earth.

If on that occasion, (in 1806,) I ventured to combine widely distributed portions of the earth's surface in a single picture of nature, and to entertain a public assembly with images whose colouring was in unison with the mournful disposition of our minds at that epoch, I will now, limiting myself to a narrower circle of phenomena, sketch the more cheerful picture of river scenery composed of foaming rapids and rich luxuriant vegetation. I propose to describe in particular two scenes of nature in the wildernesses of Guiana, - the celebrated Cataracts of the Orinoco, Atures and 
Maypures,-which, previous to my visit, few Europeans had ever seen.

The impression left on our minds by the aspect of nature is frequently determined, less even by the peculiar character of the strictly terrestrial portion of the scene, than by the light thrown on mountain or plain, either by a sky of azure purity, or by one veiled by lowering clouds; and in the same manner descriptions of nature act upon us more powerfully or more feebly, according as they are more or less in harmony with the requirements of our feelings. For it is the inward mirror of the sensitive mind which reflects the true and living image of the natural world. All that determines the character of a landscape,- the outline of the mountains, which, in the far-vanishing distance, bound the horizon,- - the dark shade of the pine forests,- - the sylvan torrent rushing between overhanging cliffs to its fall,--all are in antecedent mysterious communion with the inner feelings and life of man.

On this communion rests the nobler portion of the enjoyment which nature affords. Nowhere does she penetrate us more deeply with the feeling of her grandeur, nowhere does she speak to us with a more powerful voice, than in the tropical world, under the "Indian sky," as, in the early middle ages, the climate of the torrid zone was called. If, therefore, I venture again to occupy this Assembly with a description of those regions, I do so in the hope that the peculiar charm which belongs to them will not be unfelt. The remembrance of a distant richly endowed land,-the aspect of a free and vigorous rege- 
tation,-refreshes and strengthens the mind; in the same manner as our spirits, when oppressed with the actual present, love to escape awhile, and to delight themselves with the earlier youthful age of mankind, and with the manifestations of its simple grandeur.

Favouring winds and currents bear the voyager westward across the peaceful Ocean arm, ( $\left.{ }^{1}\right)$ which fills the wide valley between the New Continent and western Africa. Before the American shore rises from the liquid plain, he hears the tumult of contending, mutually opposing, and inter-crossing waves. The mariner unacquainted with the region would surmise the vicinity of shoals, or a wonderful outbreak of fresh springs in the middle of the ocean, $\left({ }^{2}\right)$ like those in the neighbourhood of Cuba. On approaching nearer to the granitic coast of Guiana, he becomes sensible that he has entered the wide embouchure of a mighty river, which issues forth like a shoreless lake and covers the ocean around with fresh water. The green, and on the shallows the milk-white, tint of the fresh water contrasts with the indigo-blue colour of the sea, and marks with sharp outlines the limits of the river waves.

The name Orinoco, given to the river by its first discoverers, and which probably originated in some confusion of language, is unknown in the interior of the country. Nations in a rude state designate by proper geographical names only such objects as can be confounded with each other. The Orinoco, the Amazons, and the Magdalena rivers, are called simply "The River," or "The Great River," or "The Great Water "" whilst those who dwell on their

VOL. I. 
banks distinguish even the smallest streams by particular names.

The current produced by the Orinoco, between the mainland and the Island of Trinidad with its asphaltic lake, is so strong, that ships with all sail set, and with a favourable breeze, can with difficulty make way against it. This deserted and dreaded part of the sea is called the Bay of Sadness (Golfo Triste); the entrance forms the Dragon's Mouth (Boca del Drago). Here detached cliffs rise like towers above the foaming floods, and seem still to indicate the ancient site of a rocky bulwark $\left({ }^{3}\right)$, which, before it was broken by the force of the current, united the island of Trinidad with the coast of Paria.

The aspect of this region first convinced the great discoverer of the New World of the existence of an American continent. Familiar with nature, he inferred that so immense a body of fresh water could only be collected in a long course, and "that the land which supplied it must be a continent, not an island." As, according to Arrian, the companions of Alexander, after crossing the snow-covered Paropanisus, ( $\left.{ }^{4}\right)$ on reaching the Indus imagined, from the presence of crocodiles, that they recognised in that river a branch of the Nile; so Columbus, unaware of the similarity of physiognomy which characterises the various productions of the climate of Palms, readily supposed this new continent to be the eastern coast of the far-projecting continent of Asia. The mild coolness of the evening air, the ethereal purity of the starry firmament, the balsamic fragrance of the flowers wafted to him by the land breeze,-all led him (as 
Herrara tells us in the Decades) $\left({ }^{5}\right)$, to deem that he had approached the garden of Eden, the sacred dwelling-place of the first parents of the human race. The Orinoco appeared to him to be one of the four rivers descending from Paradise, to divide and water the earth newly decked with vegetation. This poetic passage from the journal of Columbus's voyage, or rather from a letter written from Hayti, in October 1498, to Ferdinand and Isabella, has a peculiar psychological interest. It teaches us anew that the creative imagination of the poet exists in the Discoverer as in every form of human greatness.

In considering the quantity of water which the Orinoco bears to the Atlantic, the question arises-- Which of the great South American Rivers, - the Orinoco, the Amazons, or the River Plate,-is the largest? The question, however, thus put is not a determinate one, the idea of size in this case not being altogether definite. The River Plate has the widest embouchure, being 92 geographical miles across; but, like the British rivers, its length is comparatively small. Even at Buenos Ayres its depth is already so inconsiderable as to impede navigation. The Amazons is the longest of all rivers : its course from its origin in the Lake of Lauricocha to its mouth is 2880 geographical miles. But its breadth in the province of Jaen de Bracamoros, near the cataract of Rentama, as measured by me at the foot of the picturesque mountain of Patachuma, hardly equals that of the Rhine at Mayence.

The Orinoco is narrower at its mouth than either the River Plate or the Amazons; and its length, according to 
positions astronomically determined by me, only amounts to 1120 geographical miles. But, on the other hand, far in the interior of Guiana, 560 miles from its mouth, I still found its breadth, when full, 16200 Parisian (17265 Eng.) feet. The periodical swelling of the river annually raises its level at this part of its course from 30 to 36 feet above its lowest level. Sufficient materials for an accurate comparison of the enormous rivers which intersect the continent of South America are still wanting. For such a comparison it would be needful to know in each case the profile of the river-bed, and the velocity of the water, which differs very greatly in different parts of the same stream.

If, in the Delta enclosed by its variously divided and still unexplored arms, -in the regularity of its periodical rise and fall,-and in the number and size of its crocodiles,- the Orinoco shews points of resemblance to the Nile, there is this further analogy between the two rivers, that after long rushing rapidly through many windings between wood-fringed shores formed by granitic and syenitic rocks and mountains, during the remainder of their course they slowly roll their waters to the sea, between treeless banks, over an almost horizontal bed. An arm of the Nile (the Green Nile, Bahr-el-Azrek) flows from the celebrated mountain-lake near Gondar, in the Abyssinian Gojam Alps, to Syene and Elephantis, through the mountains of Shangalla and Sennaar. In a similar manner the Orinoco rises on the southern declivity of the mountain chain which, in the 4th and 5th parallel of North latitude, extends westward from French Guiana towards the Andes of New 
Granada. The sources of the Orinoco $\left(^{6}\right)$ have never been visited by any European, or even by any natives who have been in communication with Europeans.

In ascending the Upper Orinoco in the summer of 1800 , we passed the Mission of Esmeralda, and reached the mouths of the Sodomoni and the Guapo. Here rises high above the clouds the massive summit of the Yeonnamari or Duida, a grand and picturesque mountain which presents to the spectator one of the finest scenes of nature which the tropical world has to offer. Its altitude, according to my trigonometrical measurement, is 8278 (8823 Eng.) feet above the level of the sea. The southern slope of the mountain presents a treeless grassy surface, and the humid evening air is filled far and wide with the fragrance of the ripe ananas. The stalks of the pine apples, swelling with rich juice, rise between the lowly herbs of the meadow, and the golden fruit is seen shining at a distance from under its leafy crown of bluish-green. Where mountain springs or rivulets break forth from the turfy covering, the scene is further adorned by groups of tall fan-palms, whose foliage never feels the influence of a cool breeze.

On the east of the Duida mountain a dense thicket of wild Cacao groves begins, and amidst these are found trees of the celebrated Bertholletia excelsa, the most vigorous of the productions of the tropical world (7). Here the Indians collect the materials for their blow-pipes, colossal grassstalks having joints above 18 feet long from knot to knot. $\left.{ }^{8}\right)$ Some Franciscan monks have penetrated as far as the mouth of the Chiguire, where the river is already so narrow that 
the natives have thrown across it, near the waterfall of the Guaharibes, a suspension bridge formed of the twining stems of climbing plants. The Guaicas, a race of comparatively light complexion but of small stature, armed with poisoned arrows, forbid any farther advance towards the east.

All, therefore, that has been put forward respecting the lake origin of the Orinoco is fabulous (9). We seek in vain in nature for the Laguna of $\mathrm{El}$ Dorado, which is still marked in Arrowsmith's maps as an inland sea 80 geographical miles in length. Has the little reedy lake of Amucu, from which the Pirara (a branch of the Mahu) flows, given rise to this fable? But the swamp in which the lake of Amucu is situated is four degrees of longitude to the east of the district in which the sources of the Orinoco must be sought.

It was an ancient custom of dogmatising geographers to make all the larger rivers of the world originate in considerable lakes. To the lake forming the supposed origin of the Orinoco was transferred the site of the island of Pumacena, a rock of micaceous slate, the glitter of which, in the 16th century, played, in the fable of El Dorado, a memorable, and to deceived humanity often a fatal part. It is the belief of the natives, that the Magellanic clouds of the southern hemisphere, and even the fine nebulæ in the constellation of the ship Argo, are a reflection of the metallic brilliancy of the silver mountains of the Parime.

The Orinoco is one of those rivers which, after many windings, seem to return back towards the region in which 
they took their rise. After following a westerly and then a northerly course, it runs again to the east, so that its mouth is almost in the same meridian as its source. From the Chiguire and the Gehette as far as the Guaviare the Orinoco flows to the west, as if it would carry its waters to the Pacific. It is in this part of its course that it sends out towards the south a remarkable arm, the Cassiquiare, but little known in Europe, which unites with the Rio Negro, (called by the natives the Guainia), and offers perhaps the only example of a bifurcation forming in the very interior of a continent a natural connection between two great rivers and their basins.

The nature of the ground, and the junction of the Guaviare and Atabapo with the Orinoco, cause the latter to turn suddenly towards the north. In the absence of correct geographical knowledge, the Guaviare flowing in from the west was long regarded as the true origin of the Orinoco. The doubts raised by an eminent geographer, M. Buache, since 1797 , as to the probability of a connection with the Amazons, have I hope been entirely refuted by my expedition. In an uninterrupted navigation of 920 geographical miles I passed through the singular network of rivers, from the Rio Negro, by the Cassiquiare, into the Orinoco; traversing in this manner the interior of the Continent, from the Brazilian boundary to the coast of Caraccas.

In the upper portion of the basin of the Orinoco and its tributaries, between the 3rd and 4th degrees of north latitude, nature has several times repeated the enigmatical phenomenon of the so-called "black waters." The Atabapo, 
whose banks are adorned with Carolinias and arborescent Melastomas, and the Temi, Tuamini, and Guainia, are all rivers of a coffee-brown colour. In the shade of the palm groves this colour seems almost to pass into ink-black. When placed in transparent vessels, the water appears of a golden yellow. The image of the Southern Constellations is reflected with wonderful clearness in these black streams. Where their waters flow gently, they afford to the observer, when taking astronomical observations with reflecting instruments, a most excellent artificial horizon. A cooler atmosphere, less torment from stinging mosquitoes, greater salubrity, and the absence of crocodiles (fish, however, are also wanting), mark the region of these black rivers. They probably owe their peculiar colour to a solution of carburetted hydrogen, to the luxuriance of the tropical vegetation, and to the quantity of plants and herbs on the ground over which they flow. On the western declivity of the Chimborazo, towards the coast of the Pacific, I remarked that the flooded waters of the Rio de Guayaquil gradually assumed a golden yellow or almost coffee-brown colour, when covering the meadows for some weeks.

In the vicinity of the mouths of the Guaviare and Atabapo grows the Piriguao, $\left({ }^{10}\right)$ one of the noblest of palm trees, whose smooth and polished trunk, between 60 and 70 feet high, is adorned with a delicate flag-like foliage curled at the margins. I know no palm which bears such large and beautifully coloured fruits. They resemble peaches, and are tinged with yellow mingled with a roseate crimson. Seventy or eighty of them form enormous pendulous bunches, of 
which each tree annually ripens three. This fine tree might be called the peach palm. The fleshy fruits are from the luxuriance of regetation most often devoid of seeds, and offer to the natives a nutritious farinaceous food which, like plantains and potatoes, can be prepared in a variety of ways.

Hitherto, or as far as the mouth of the Guaviare, the Orinoco flows along the southern declivity of the Sierra de Parime; and from its southern bank the vast forestcovered plain of the Amazons River stretches far beyond the equator, even to the 15th degree of south latitude. When the Orinoco turns suddenly to the north near San Fernando de Atabapo, it breaks through a part of the mountain chain along the base of which it had previously flowed; and this is the site of the great waterfalls of Atures and Maypures. The river bed is here everywhere hemmed in by colossal masses of rock, and divided as it were into separate reservoirs by natural dikes.

In front of the entrance of the Meta there stands in the middle of a mighty whirlpool an isolated cliff, to which the natives have given the very appropriate name of the "rock of patience;" because when the waters are low it sometimes costs those who are ascending the river two days to pass it. Here the Orinoco, eating deep into the land, forms picturesque rocky bays. Opposite to the Indian mission of Carichana the traveller is surprised by the singular prospect which presents itself to his view. His eye is involuntarily riveted on an abrupt granitic rock, el Mogote de Cocnyza, a cube with vertically precipitous sides, above 200 feet high and bearing on its upper surface a forest of trees of rich and varied 
foliage. Resembling a Cyclopean monument in its simple grandeur, this mass of rock rises high above the tops of the surrounding palms, its sharp outlines appearing in strong relief against the deep azure of the sky, and its summit uplifting high in air a forest above the forest.

In descending the Orinoco from this point, still within the range of the Carichana mission, we arrive at the part of the river where the stream has forced for itself a way through the narrow pass of Baraguan. Here we recognise everywhere traces of chaotic devastation. To the north, (towards Uruana and Encaramada), masses of granite of extraordinarily notched and serrated outline and grotesque aspect shine with dazzling whiteness high above the thickets from amidst which they rise.

It is in this region, after receiving the Apure, that the Orinoco leaves the granitic chain of mountains and flows eastward to the Atlantic, dividing the impenetrable forests of Guiana from the grassy plains on which the vault of heaven seems everywhere to rest as on the horizon of the ocean. Thus the elevated cluster of the Parime mountains, which occupies the entire space between the sources of the Jao and the Caura, is surrounded on three sides, to the South, to the West, and to the North, by the Orinoco. Below Carichana the course of the river is uninterrupted by rocks or rapids to its mouth, excepting at the whirlpool of the Boca del Infierno (Hell's mouth) near Muitaco, where, however, the rocks which occasion the rapid do not extend across the entire bed of the river as at Atures and Maypures. In these lower parts of the river in the vicinity of the sea, the only danger feared by 
the boatmen is that of encountering the great natural rafts, consisting of trees torn from the banks by the swelling of the river, against which canoes are often wrecked during the night. These rafts, covered like meadows with flowering water plants, remind the spectator of the floating gardens of the Mexican lakes.

After this rapid review of the course of the Orinoco, and of its general relations to the surrounding country, I pass to the description of the Falls of Maypures and Atures.

Between the sources of the rivers Sipapo and Ventuari a granite ridge projects from the elevated mountain group of Cunavami, and advances far to the west towards the mountains of Uniama. Four streams, which may be said to mark the limits of the cataracts of Maypures, descend from this ridge; two, the Sipapo and the Sanariapo, on the eastern side of the Orinoco ; and two, the Cameji and the Toparo, on its western side. Near the Missionary village of Maypures the mountains retire and form a wide bay open to the south-west.

The foaming stream flows at the present time at the foot of the eastern mountain declivity, and far to the west we recognise the ancient bank now forsaken by the water. A grass-covered plain, only about thirty feet above the present highest level of the river, extends between the two chains of hills. The Jesuits have built upon it a small church formed of the trunks of palm trees.

The geological aspect of the district, the shapes of the rocks of Keri and Oco, which have so much the character of islands, the water-worn hollows in the first named of these rocks, situated at exactly the same height as the cavities in the opposite island of Uivitari, all testify that the Orinoco 
once filled the whole of this now dry gulf or bay. Probably the waters formed a wide lake as long as the northern dike was able to withstand their pressure. When it gave way, the prairie now inhabited by the Guareke Indians must have been the first part which appeared above the waters; which may subsequently, perhaps, have long continued to surround the rocks of Keri and Oco, which rising like mountain fortresses from the ancient bed of the river, present a picturesque aspect. As the waters gradually diminished they withdrew altogether to the foot of the eastern hills, where the river now flows.

This conjecture is confirmed by several circumstances. The Orinoco, like the Nile near Philæ and Syene, has the property of imparting a black colour to the reddish white masses of granite which it has bathed for thousands of years. As far as the waters reach, one may remark on the rocky shore the leaden-coloured coating described in page 189 : its presence, and the hollows before mentioned, mark the ancient height of the waters of the Orinoco.

In the rock of Keri, in the islands of the Cataracts, in the gneiss hills of Cumadaminari above the island of Tomo, and lastly at the mouth of the Jao, we trace these black-coloured hollows at elevations of 150 to 180 (160 to 192 English) feet above the present height of the river. Their existence teaches us a fact of which we may also observe indications in the river beds of Europe; viz. that the streams whose magnitude now excites our astonishment are only the feeble remains of the immense masses of water belonging to an earlier age of the world.

These simple remarks and inferences have not escaped 
even the rude natives of Guiana. The Indians everywhere called our attention to the traces of the former height of the waters. There is in a grassy plain near Uruana an isolated granite rock, on which, according to the report of trustworthy witnesses, there are at a height of more than eighty feet drawings of the sun and moon, and of many animals, particularly crocodiles and boas, engraven or arranged almost in rows or lines. Without artificial aid it would now be impossible to ascend this perpendicular precipice, which deserves to be carefully examined by future travellers. The hieroglyphical rock engravings on the mountains of Uruana and Encaramada are equally remarkable in respect to situation.

If one asks the natives how these figures can have been cut in the rocks, they answer that it was done when the waters were so high that their fathers' boats were only a little lower than the drawings. Those rude memorials of human art would in such case have belonged to the same age as a state of the waters implying a distribution of land and water very different from that which now prevails, and belonging to an earlier condition of the earth's surface; which must not, however, be confounded with that in which the earlier vegetation which adorned our planet, the gigantic bodies of extinct land animals, and the oceanic creatures of a more chaotic state, became entombed in the indurating crust of globe.

At the northernmost extremity of the cataracts, attention is excited by what are called the natural drawings or pictures of the Sun and Moon. The rock Keri, to which I have 
several times referred, has received its name from a white spot which is conspicuous from a great distance, and in which the Indians have thought they recognised a remarkable similarity to the disk of the full moon. I was not myself able to climb the steep precipice, but the white mark in question is probably a large knot of quartz formed by a cluster of veins in the greyish-black granite.

Opposite to the Keri rock, on the twin mountain of the island of Uivitari, which has a basaltic appearance, the Indians shew with mysterious admiration a similar disk which they venerate as the image of the Sun, Camosi. Perhaps the geographical position of the two rocks may have contributed to these denominations, as the Keri (or Moon Rock) is turned to the West, and the Camosi to the East. Some etymologists have thought they recognised in the American word Camosi a similarity to Camosh, the name of the Sun in one of the Phœnician dialects, and to Apollo Chomeus, or Beelphegor and Ammon.

Unlike the grander falls of Niagara (which are 140 French or 150 English feet high) the "Cataracts of Maypures" are not formed by the single precipitous descent of a vast mass of waters, nor are they "narrows" or passes through which the river rushes with accelerated velocity, as in the Pongo of Manseriche in the River of the Amazons. The Cataracts of Maypures consist of a countless number of little cascades succeeding each other like steps. The " Raudal" (the name given by the Spaniards to this species of catarect) is formed by numerous islands and rocks which so restrict the bed of the river, that out of a breadth of 8000 
(8526 E.) feet there often only remains an open channel of twenty feet in width. The eastern side is now much more inaccessible and dangerous than the western.

At the confluence of the Cameji with the Orinoco, goods are unladen in order that the empty canoe, or, as it is here called, the Piragua, may be conveyed by Indians well acquainted with the Raudal to the mouth of the Toparo, where the danger is considered to be past. Where the separate rocks or steps (each of which is designated by a particular name) are not much above two or three feet high, the natives, if descending the stream, venture, remaining themselves in the canoe, to let it go down the falls : if they are ascending the stream they leave the boat, swim forward, and when after many unsuccessful attempts they have succeeded in casting a rope round the points of rock which rise above the broken water, they draw up their vessel, which is often either overset or entirely filled with water in the course of these laborious proceedings.

Sometimes, and it is the only case which gives the natives any uneasiness, the canoe is dashed in pieces against the rocks; the men have then to disengage themselves with bleeding bodies from the wreck and from the whirling force of the torrent, and to gain the shore by swimming. Where the rocky steps are very high and extend across the entire bed of the river, the light boat is brought to land and drawn along the bank by means of branches of trees placed under it as rollers.

The most celebrated and difficult steps, those of Purimarimi and Manimi, are between nine and ten feet high. I 
found with astonishment by barometric measurements, (geo desical levelling being out of the question from the inaccessibility of the locality, its highly insalubrious atmosphere, and the swarms of mosquitoes which fill the air), that the whole fall of the Raudal from the mouth of the Cameji to that of the Toparo hardly amounts to 28 or 30 feet (30 or 32 English). I say, "I found with astonishment ;" for this shews that the dreadful noise and wild dashing and foaming of the river are the results of the narrowing of its bed by countless rocks and islands, and of the counter currents produced by the form and situation of the masses of rock. The best ocular demonstration of the small height of the whole fall is obtained by descending from the village of Maypures to the bed of the river by the rock of Manimi.

From this point a wonderful prospect is enjoyed. A foaming surface of four miles in length presents itself at once to the eye : iron-black masses of rock resembling ruins and battlemented towers rise frowning from the waters. Rocks and islands are adorned with the luxuriant vegetation of the tropical forest; a perpetual mist hovers over the waters, and the summits of the lofty palms pierce through the cloud of spray and vapour. When the rays of the glowing evening sun are refracted in these humid exhalations a magic optical effect begins. Coloured bows shine, vanish, and reappear; and the ethereal image is swayed to and fro by the breath of the sportive breeze. During the long rainy season the streaming waters bring down islands of vegetable mould, and thus the naked rocks are studded with bright flower-beds adorned with Melastomas and 
Droseras, and with small silver-leaved mimosas and ferns. These spots recal to the recollection of the European those blocks of granite decked with flowers which rise solitary amidst the glaciers of Savoy, and are called by the dwellers in the Alps "Jardins," or "Courtils."

In the blue distance the eye rests on the mountain chain of Cunavami, a long extended ridge which terminates abruptly in a truncated cone. We saw the latter, (Calitamini is its Indian name), glowing at sunset as if in roseate flames. This appearance returns daily: no one has ever been near the mountain to detect the precise cause of this brightness, which may perhaps proceed from a reflecting surface produced by the decomposition of talc or mica slate.

During the five days which we passed in the neighbourhood of the cataracts, it was striking to hear the thunder of the rushing torrents sound three times louder by night than by day. In all European waterfalls the same phenomenon is remarked. What can be its cause in a wilderness where there is nothing to interrupt the repose of nature? Perhaps the currents of heated ascending air by causing irregular density in the elastic medium impede the propagation of sound during the day, by the disturbance they may occasion in the waves of sound; whereas during the nocturnal cooling of the earth's surface the upward currents cease.

The Indians called our attention to ancient tracks of wheels. They speak with admiration of the horned animals, (oxen), which in the times of the Jesuit missions used to draw the canoes on wheeled supports, along the left bank of the Orinoco, from the mouth of the Cameji to that of the

voL. I. 
Toparo. The lading was not then removed from the boats, nor were the latter worn and injured as they now are by being constantly stranded upon the rocks and dragged over their rough surface.

The topographical plan of the district 'sketched by me shews the facilities which the nature of the ground offers for the opening of a canal from the Cameji to the Toparo, which would form a navigable side arm to the river, the dangerous portion of which would be thus avoided. I proposed its execution to the Governor-General of Venezuela.

The Raudal of Atures closely resembles that of Maypures; like it, it is a cluster of islands between which the river forces its way for ten or twelve thousand yards ; a forest of palms rising from the midst of the foaming waters. The most celebrated "Steps" of this Raudal are situated between the islands of Avaguri and Javariveni, between Suripamana and Uirapuri.

When M. Bonpland and I returned from the banks of the Rio Negro, we ventured to pass the latter or lower half of the Raudal of Atures with the loaded canoe, often leaving it for the rocky dikes which connect one island with another. Sometimes the waters rush over these dikes, and sometimes they fall with a hollow thundering sound into cavities, and flowing for a time through subterranean channels, leave large pieces of the bed of the river dry. Here the golden Pipra rupicola makes its nest; it is one of the most beautiful of tropical birds, with a double moveable crest of feathers, and is as pugnacious as the East Indian domestic cock. 
In the Raudal of Canucari the rocky dike or weir consists of piled-up granite spheres. We crept into the interior of a grotto the damp walls of which were covered with confervæ and shining Byssus, and where the river rushed high above our heads with deafening noise.

We had accidentally more time than we desired for the enjoyment of this grand scene of nature. The Indians had left us in the middle of the cataract, proposing to take the canoe round a long narrow island below which we were to re-embark. We waited an hour and a half under a heavy tempestuous rain; night was coming on, and we sought in vain for shelter between the masses of granite. The little monkeys, which we had carried with us for months in wicker cages, by their mournful cries attracted crocodiles whose size and leaden-grey colour shewed their great age. I should not here notice an occurrence so usual in the Orinoco, if the Indians had not assured us that no crocodiles were ever seen in the cataracts; and in dependence on this as. surance we had even ventured repeatedly to bathe in this part of the river. Meanwhile our anxiety lest we might be forced to pass the long tropical night in the middle of the Raudal, wet through and deafened by the thundering noise of the falling waters, increased every moment; until at last the Indians reappeared with our canoe. From the low state of the waters they had found the steps by which they had intended to let themselves down inaccessible, and had been forced to seek among the labyrinth of channels for a more practicable passage.

Near the southem entrance of the Raudal of Atures, on 
the right bank of the river, is the cave of Ataruipe, which is widely celebrated among the Indians. The grand and melancholy character of the scenery around fits it for the burying-place of a deceased nation. We climbed with diffculty, and not without danger of falling to a great depth below, a steep and perfectly bare granite precipice. It would be hardly possible to keep one's footing on the smooth surface, if it were not for large crystals of feldspar, which, resisting " weathering," project as much as an inch from the face of the rock.

On reaching the summit the traveller beholds a wide, diversified, and striking prospect. From the foaming riverbed rise wood-crowned hills, while beyond the western shore of the Orinoco the eye rests on the boundless grassy plain of the Meta, uninterrupted save where at one part of the horizon the Mountain of Uniama rises like a threatening cloud. Such is the distance; the nearer prospect is desolate, and closely hemmed in by high and barren rocks. All is motionless save where the vulture or the hoarse goatsucker hover solitarily in mid-air, or, as they wing their flight through the deep-sunk ravine, their silent shadows are seen gliding along the face of the bare rocky precipice until they vanish from the eye.

This precipitous valley is bounded by mountains on whose rounded summits are enormous detached granite spheres of more than 40 to 50 feet diameter : they appear to touch the base on which they rest only in a single point, as if the slightest movement, such as that of a faint earthquake shock, must cause them to roll down. 
The farther part of the valley is densely wooded, and it is in this shady portion that the cave of Ataruipe is situated. It is not properly speaking a cave, but rather a vaulted roof formed by a far over-hanging cliff, the cavity having apparently been formed by the waters when at their ancient level. This place is the vault or cemetery of an extinct nation. (11) We counted about 600 well-preserved skeletons placed in as many baskets woven from the stalks of palm leaves. These baskets, which the Indians call " mapires," are shaped like square sacks, differing in size according to the age of the deceased. Even new-born children had each its own mapire. The skeletons are so perfect that not a bone or a joint is wanting.

The bones had been prepared in three different ways; some bleached, some coloured red with onoto, the pigment of the Bixa Orellana; and some like mummies closely enveloped in sweet-smelling resin and plantain leaves.

The Indians assured us that the custom had been to bury the fresh corpses for some months in damp earth, which gradually consumed the flesh; they were then dug up, and any remaining flesh scraped away with sharp stones. This the Indians said was still the practice of several tribes in Guiana. Besides the mapires or baskets we found urns of half burnt clay which appeared to contain the bones of entire families. The larger of these urns were about three feet high and nearly six feet long, of a pleasing oval form and greenish colour, having handles shaped like snakes and crocodiles, and meandering or labyrinthine ornaments round the upper margin. These ornaments are quite similar to 
those which cover the walls of the Mexican Palace at Mitla. They are found in all countries and climates, and in the most different stages of human cultivation,- - among the Greeks and Romans, as well as on the shields of the natives of Tahiti and other islands of the South Sea,-wherever the eye is gratified by the rhythmical recurrence of regular forms. These similarities, as I have elsewhere remarked in more detail, are rather to be ascribed to psychological causes, or to such as belong inherently to our mental constitution, than to be viewed as evidences of kindred descent or ancient intercourse between different nations.

Our interpreters could give us no certain information as to the age of these vessels; that of the skeletons appeared for the most part not to exceed a century. It is reported among the Guareca Indians, that the brave Atures, being pressed upon by cannibal Caribs, withdrew to the rocks of the Cataracts; a melancholy refuge and dwelling-place, in which the distressed tribe finally perished, and with them their language. In the most inaccessible parts of the Raudal there are cavities and recesses which have served like the cave of Ataruipe as burying-places. It is even probable that the last family of the Atures may not have been long deceased, for (a singular fact,) there is still in Maypures an old parrot of whom the natives affirm that he is not understood because he speaks the Ature language.

We left the cave at nightfall, after having collected, to the great displeasure of our Indian guides, several skulls and the entire skeleton of a man. One of these skulls has been figured by Blumenbach in his excellent craniological work, 
but the skeleton (together with a large part of our natural history collections, especially the entomological) was lost in a shipwreck on the coast of Africa, in which our friend and former travelling companion, the young Franciscan monk Juan Gonzalez, perished.

As if with a presentiment of this painful loss, we turned our steps in a thoughtful and melancholy mood from this burying-place of a race deceased. It was one of those clear and cool nights so frequent in the tropics. The moon, encircled with coloured rings, stood high in the zenith illuminating the margin of the mist which lay with well-defined cloud-like outlines on the surface of the foaming river. Countless insects poured their red phosphoric light on the herb-covered ground, which glowed with living fire as if the starry canopy of heaven had sunk down upon the turf. Climbing Bignonias, fragrant Vanillas, and yellow-flowering Banisterias, adorned the entrance of the cave; and the summits of the palms rnstled above the graves.

Thus perish the generations of men! Thus do the name and the traces of nations fade and disappear! Yet when each blossom of man's intellect withers,-when in the storms of time the memorials of his art moulder and decay, - an ever new life springs forth from the bosom of the earth ; maternal Nature unfolds unceasingly her germs, her flowers, and her fruits; regardless though man with his passions and his crimes treads under foot her ripening harvest. 



\section{ANNOTATIONS AND ADDITIONS.}

(1) p. 209.- "Across the peac'eful ocean arm, which fills the wide valley between the American shore and Western Africa."

The Atlantic Ocean, from the 23d degree of South to the 70th degree of North latitude, has the form of an excavated longitudinal valley, in which the salient and re-entering angles are opposite to each other. I first developed this idea in my "Essai d'un Tableau géologique de l'Amérique méridionale," printed in the Journal de Physique, T. liii. p. 61. (Geognostische Skizze von Südamerika, in Gilbert's Annalen der Physik, Bd. xvi. 1804, S. 394-449.) From the Canaries, and especially from the 21st degree of North latitude and the 23d degree of West longitude, to the North-East coast of South America, the surface of the sea is usually so calm, aud the waves so gentle, that an open boat might navigate in safety.

(2) p. 209.-_" A wonderfut outbreak of fresh springs in the middle of the ocean."

On the southern coast of the island of Cuba, south-west of the Port of Batabano in the gulf of Xagua, a few miles from the coast, springs of fresh water gush from the bed of the ocean probably under the influence of hydrostatic pres- 
sure, and rise through the midst of the salt water. They issue forth with such force that boats are cautious in approaching this locality, which has an ill repute on account of the high cross sea thus caused. Trading vessels sailing along the coast and not disposed to land, sometimes visit these springs to take in a supply of fresh water, which is thus obtained in the open sea. The greater the depth from which the water is taken, the fresher it is found to be. The "river cow," Trichecus manati, which does not remain habitually in salt water, is often killed here. This remarkable phenomenon of fresh springs issuing from the sea has been most carefully examined by a friend of mine, Don Francisco Lemaur, who made a trigonometrical survey of the Bay of Xagua. I have been farther to the South in the group of islands called the Jardines del Rey, (the King's Gardens), making astronomical observations for latitude and longitude; but I have never been at Xagua itself.

(3) p. 210.- " The ancient site of u rocky bulwark."

Columbus, whose unwearied spirit of observation exerted itself in every direction, propounds in his letters to the Spanish monarchs a geognostical hypothesis respecting the forms of the larger Antilles. Having his mind deeply impressed with the strength of the East and West Equinoctial current, he ascribes to it the breaking up of the group of the smaller West Indian islands, and the singularly lengthened configuration of the southern coasts of Porto Rico, Haiti, Cuba, and Jamaica, which all follow almost exactly the direction of 
parallels of latitude. On his third voyage (from the end of May 1498 to the end of November 1500), in which, from the Boca del Drago to the Island of Margarita, and afterwards from that island to Haiti, he felt the whole force of the Equinoctial current, "that movement of the waters which is in accordance or conformity with the movement of the heavens-movimiento de los cielos," he says expressly that the Island of Trinidad had been torn from the mainland by the violence of the current. He alludes to a chart which he sends to the monarchs, - a "pintura de la tierra" by himself, which is often referred to in the celebrated lawsuit against Don Diego Colon respecting the rights of the Admiral. "Es la carta de marear y figura que hizo el Almirante señalando los rumbos y vientos por los quales vino á Paria, que dicen parte del Asia", (Navarrete Viages y Descubrimientos que hiciéron por mar los Españoles, T. i. p. 253 and 260 ; T. ii. p. 539 and 587.)

(4) p. 210.- "Over the snow-covered Paropanisus."

Diodorus's descriptions of the Paropanisus (Diodor. Sicul. lib. xvii. p. 553, Rhodom.) might almost pass for a description of the Andes of Peru. The Army passed through inhabited places where snow fell daily!

$\left.{ }^{5}\right)$ p. 211.- "Herrara in the Decades."

Historia general de las Indias occidentales, Dec. i. lib iii. cap. 12 (ed. 1601, p. 106] ; Juan Bautista Muñoz, Historia del Nuevo Mundo, lib. vi. c. 31, p. 301 ; Humboldt, Examen Crit. T. iii p. 111. 
$\left.{ }^{6}\right)$ p. 213.- "The Sources of the Orinoco have never been visited by any European."

Thus I wrote respecting these sources in the year 1807, in the first edition of the "Ansichten der Natur," and I have to repeat the same statement after an interval of 41 years. The travels of the brothers Robert and Richard Schomburgk, so important for all departments of natural knowledge and geography, have afforded us thorough investigations of other and more interesting facts; but the problem of the situation of the sources of the Orinoco has been only approximately solved by Sir Robert Schomburgk. It was from the West that M. Bonpland and myself advanced as far as Esmeralda, or the confluence of the Orinoco and the Guapo; and I was able to describe with certainty, by the aid of well-assured information, the upper course of the Orinoco to above the mouth of the Gehette, and to the small Waterfall (Raudal) de los Guaharibos. It was from the East that Robert Schomburgk, advancing from the mountains of the Majonkong Indians, (the altitude of the inhabited portions of which he estimated by the boiling point of water at $3300 \mathrm{~F}$., or $3517 \mathrm{E}$. feet), came to the Orinoco by the Padamo River, which the Majonkongs and Guinaus (Guaynas?) call Paramu (Reisen in Guiana, 1841, S. 448). In my Atlas I had estimated the position of the confluence of the Padamo with the Orinoco at N. lat. $3^{\circ} 12^{\prime}$, and W. long. $65^{\circ} 46^{\prime}$ : Robert Schomburgk found it by direct observation, lat. $2^{\circ} 53^{\prime}$, long. $65^{\circ} 48^{\prime}$. The leading object of this traveller's arduous journey was not the pursuit of natural history, but the solution of the prize ques- 
tion proposed by the Royal Geographical Society of London in November 1834, - viz. the connection of the coast of British Guiana with the easternmost point which I had reached on the Upper Orinoco. After many difficulties and much suffering, the desired objectwas completely attained. Robert Schomburgk arrived with his instruments on the $22 \mathrm{~d}$ of February, 1839, at Esmeralda. His determinations of the latitude and longitude of the place agreed more closely with mine than I had expected would be the case (S. xviii. and 471). Here let us allow the observer to speak for himself :- "I want words to describe the feelings wlich overpowered me as I sprang to shore. My aim was attained; my observations, began on the coast of Guiana, were brought into connection with those of Humboldt at Esmerulda: I frankly own, that in the course of this enterprise, at a time when almost all my physical powers had well nigh deserted me, and when I was surrounded by dangers and difficulties of no common nature, it was only by the recognition which I hoped for from him, that I had been encouraged to press onward with unalterable determination towards the goal which I had now reached. The emaciated figures of my Indians and faithful guides told more plainly than any words could do, what difficulties we had had to surmount, and had surmounted." After expressions so kind towards myself, I must be permitted to subjoin the following passage, extracted from my Preface to the German Edition of Robert Schomburgk's Account of his Travels, published in 1841.

"Immediately after my return from Mexico, I notified 
the direction and the routes which should be followed to explore the unknown portion of the South American Continent between the sources of the Orinoco, the mountain chain of Pacaraima, and the sea-shore near Essequibo. These wishes, which I expressed so strongly in my Rélation Historique, have at last, after the lapse of almost half a century, been for the greater part fulfilled. Besides the joy of having lived to see so important an extension of our geographical knowledge, I have had that of seeing it attained by means of a courageous and well-conducted enterprise, requiring the most devoted perseverance, executed by a young man with whom I feel united by the double bond of similarity of pursuits and efforts, and of our common country. Motives such as these have alone been sufficient to overcome the distaste which I entertain, perhaps without reason, to introductory prefaces by another hand than that of the author of the work. But in this case I could not consent to forego the opportunity of expressing, thus publicly, my heartfelt esteem for the accomplished traveller who, in pursuit of an object deriving all its interest from the mind,-namely, in the self-imposed task of penetrating from East to West, from the Valley of the Essequibo to Esmeralda,-succeeded, after five years of efforts and of sufferings (which I can in part appreciate from my own experience), in reaching the goal which he had proposed to himself. Courage for the momentary execution of a hazardous action is more easily met with, and implies less of inward strength, than does the resolution to endure patiently long-continued physical sufferings, incurred 
in the pursuit of some deeply-felt mental interest, and still to determine to go forward, undismayed by the certainty of having to retrace the same painful route, and to support the same privations in returning with enfeebled powers. Serenity of mind, almost the first requisite for an undertaking in inhospitable regions, passionate love for some class of scientific labour, (be it in natural history, astronomy, hypsometrics, magnetism, or aught else,) and a pure feeling for the enjoyment which nature in her freedom is ready to impart, are elements which, when they meet together in an individual, ensure the attainment of valuable results from a great and important journey."

In discussing the question respecting the sources of the Orinoco, I will begin with the conjectures which I had myself formed on the subject. The dangerous route travelled in 1739 by the surgeon Nicolas Hortsmann, of Hildesheim; in 1775 by the Spaniard Don Antonio Santos, and his friend Nicolas Rodriguez; in $\mathbf{1 7 9 3}$ by the Lieutenant-Colonel of the 1st Regiment of the Line of Para, Don Francisco Jose Rodriguez Barata; and (according to manuscript papers, for which I am indebted to the former Portuguese Ambassador in Paris, Chevalier de Brito) by several English and Dutch settlers, who in 1811 went from Surinam to Para by the Portage of the Rupunuri and by the Rio Branco ;-divides the terra incognita of the Parime into two unequal portions, and serves to limit the situation of a very important point in the geography of those regions-viz. the sources of the Orinoco, which it is no longer possible to remove to an uncertain disance to the East, without interfering thereby with what we 
know of the course of the Rio Branco, which flows from north to south through the basin of the Upper Orinoco; while that river itself, in this part of its course, pursues for the most part an East and West direction. From political reasons, the Brazilians, since the beginning of the present century, have testified a lively interest in the extensive plains east of the Rio Branco. See the memoir which I drew up at the request of the Portuguese court in 1817, "sur la fixation. des limites des Guyanes Française et Portuguaise” (Schoell, Archives historiques et politiques, ou Recueil de Pièces officielles, Memoires, \&c. T. i. 1818, p. 48-58). Viewing the position of Santa Rosa on the Uraricapara, the course of which appears to have been determined with tolerable accuracy by Portuguese engineers, the sources of the Orinoco cannot be looked for east of the meridian of $65 \frac{1}{2}^{\circ}$ from Paris, $\left(63^{\circ} .8^{\prime} \mathrm{W}\right.$. long. from Greenwich). This being the eastern limit beyond which they cannot be placed, and considering the state of the river at the Raudal de los Guaharibos (above Caño Chiguire, in the country of the surprisingly fair-skinned Guaycas Indians, and 52' East of the great Cerro Duida), it appears to me probable that the upper part of the Orinoco does not really extend, at the utmost, beyond the meridian of $66 \frac{1}{2}^{\circ}$ from Paris $\left(64^{\circ} .08^{\prime}\right.$ W. from Greenwich.) This point is according to my combinations $4^{\circ} .12$ West of the little lake of Amucu, which was reached by Sir Robert Schomburgk.

I next subjoin the conjectures of that gentleman, having given the earlier ones formed by myself. According to his view, the course of the upper Orinoco to the east of Esme- 
ralda is directed from South-east to North-west ; my estimations of latitude for the mouths of the Padamo and the Gehette appearing to be respectively 19 and $36^{\prime}$ too small. Robert Schomburgk supposes the sources of the Orinoco to be in lat. $2^{\circ} .30^{\prime}$ (S. 460); and the fine "Map of Guayana, to illustrate the route of R. H. Schomburgk," which accompanies the splendid English work entitled "Views in the Interior of Guiana," places the sources of the Orinoco in $67^{\circ} .18^{\prime}$ (W. from Paris), i. e. $1^{\circ} .6^{\prime}$ west of Esmeralda, and only $48^{\prime}$ of longitude nearer to the Atlantic than I had thought admissible. From astronomical combinations Schomburgk has placed the mountain of Maravaca, which is upwards of nine thousand feet high, in lat. $3^{\circ} .41^{\prime}$ and long. $65^{\circ} .38^{\prime}$ Near the mouth of the Padamo or Paramú the Orinoco was scarcely three hundred yards wide; and more to the west, where it spreads to a breadth of from four to six hundred yards, it was so shallow and so full of sandbanks that the Expedition were obliged to dig channels, the river bed being only fifteen inches deep. Fresh water Dolphins were still to be seen everywhere in large numbers; a phenomenon which the zoologists of the 18th century would not have been prepared to expect in the Orinoco and the Ganges.

(7) p. 213.- " The most vigorous of the productions of the tropical world."

The Bertholletia excelsa (Juvia), of the family of Myrtaceæ (and placed in Richard Schomburgk's proposed division of Lecythidex), was first described by Bonpland and myself in voL $I$. 
the "Plantes équinoxiales," T. i. 1808, p. 122, tab. 36. This gigantic and magnificent tree offers, in the perfect formation of its cocoa-like, round, thick, woody fruit enclosing the three-cornered and also woody seed-vessels, the most remarkable example of high organic development. The Bertholletia grows in the forests of the Upper Orinoco between the Padamo and the Ocamu, near the mountain of Mapaya, and also between the rivers Amaguaca and Gehette. (Rélation historique, T. ii. p. 474, 496, 558-562.)

(8) p. 213.- " Grass stalks having joints above eighteen feet long from knot to knot."

Robert Schomburgk, when visiting the small mountainous country of the Majonkongs, on his way to Esmeralda, was so fortunate as to determine the species of Arundinaria which furnishes the material for the blowpipes or tubes through which the Indians discharge their arrows. He says of this plant: "It grows in large tufts like the Bambusa; the first joint rises without a knot to a height of from 16 to 17 feet before it begins to put forth leaves. The entire height of the Arundinaria, as it grows at the foot of the great mountain of Maravaca, is from 30 to 40 feet, with a thickness of scarcely half an inch diameter. The top is always inclined. This kind of grass is peculiar to the sandstone mountains between the Ventuari, the Paramu (Padamo), and the Mavaca. The Indian name is Curata, and hence, from the excellence of these far-famed blow tubes of great length, the Majonkongs and Guinaus of these 
districts have been given the names of the Curata nation." (Reisen in Guiana und am Orinoco, S. 451.)

\section{$\left.{ }^{9}\right)$ p. 214.- “Fabulous lake-origin of the Orinoco."}

The lakes of these regions (some of which have had their real size much exaggerated by theoretical geographers, while the existence of others is purely imaginary), may be divided into two groups. The first of these groups comprises the lakes, whether real or imaginary, placed between Esmeralda (the easternmost mission on the upper Orinoco), and the Rio Branco; and the second those assumed to exist in the district between the Rio Branco and French, Dutch, and British Guiana. This general view, of which travellers should never lose sight, shews that the question of whether there is yet a Lake Parime east of the Rio Branco, other than the Lake Amucu, seen by Hortsmann, Santos, Colonel Barata, and Schomburgk, has nothing whatever to do with the problem of the sources of the Orinoco. As the name of my friend the former Director of the Hydrographic Office at Madrid, Don Felipe Bauza, is deservedly of great weight in geography, the impartiality which ought to preside over every scientific investigation makes me feel it a duty to recall that this learned man was inclined to the view, that there must be lakes west of the Rio Branco and not far from the sources of the Orinoco. He wrote to me from London, a short time before his death: "I wish you were here, that I might converse with you on the subject of the geography of the upper Orinoco, which has occupied you 
so much. I have been so fortunate as to rescue from entire destruction the papers of the General of Marine, Don José Solano, father of the Solano who perished in so melancholy a manner at Cadiz. These documents relate to the boundary division between the Spaniards and the Portuguese, with which the elder Solano had been charged, in conjunction with Chef d'Escadron Yturriaga and Don Vicente Doz, since 1754. In all these plans and sketches I see a Laguna Parime, represented sometimes as the source of the Orinoco, and sometimes quite detached from that river. Are we, then, to admit the existence of another lake north-east of Esmeralda?"

Löffling, the celebrated pupil of Linnæus, came to Cumana as the botanist of the boundary expedition above alluded to. After traversing the missions on the Piritu and the Caroni he died on the 22d of February, 1756, at the mission of Santa Eulalia de Murucuri, a little to the south of the confluence of the Orinoco and the Caroni. The documents of which Bauza speaks are the same as those on which the great map of De la Cruz Olmedilla is based. They constitute the type of all the maps which appeared in England, France, and Germany up to the close of the last century; and they also served for the two maps drawn in 1756 by Peter Caulin, the historian of Solano's expedition, and by an unskilful compiler, M. de Surville, Keeper of the Archives of the Secretary of State's office at Madrid. The discordance between these maps shews the little dependence which can be placed on the surveys of the expedition; besides which, Caulin's acute remarks lead us to perceive 
the circumstances which gave occasion to the fiction of the Lake Parime; and Surville's map, which accompanies his work, not only restores this lake under the name of the White Sea and of the Mar Dorado, but also adds another lake, from which, partly through lateral outlets, the Orinoco, the Siapa, and the Ocamo issue. I was able to satisfy myself on the spot of the fact, well known in the missions, that Don José Solano went indeed beyond the cataracts of Atures and Maypures, but not beyond the confluence of the Guaviare and the Orinoco, in lat. $4^{\circ} .3^{\prime}$ and long. $68^{\circ} .09^{\prime}$; that the instruments of the Boundary Expedition were not carried either to the Isthmus of the Pimichin and the Rio Negro, or to the Cassiquiare; and that even on the Upper Orinoco they were not taken above the mouth of the Atabapo. This extensive country, in which previous to my journey no exact observations had been attempted, had been traversed since the time of Solano only by a few soldiers sent in search of discoveries; and Don Apolinario de la Fuente (whose journals I obtained from the archives of the province of Quiros), had collected, without critical discrimination, from the lying tales told by Indians, whatever could flatter the credulity of the governor Centurion. No member of the Expedition had seen any lake, and Don Apolimario had not advanced farther than the Cerro Yumariquin and the Gehette.

Having now established throughout the extensive district, to which it is desired to direct the inquiring zeal of travellers, a dividing line bounding the basin of the Rio Branco, it still remains to remark, that for a century past no advance has 
taken place in our geographical knowledge of the country west of this valley between $61 \frac{1}{2}^{\circ}$ and $65 \frac{1}{2}^{\circ} \mathrm{W}$. longitude. The attempts repeatedly made by the Government of Spanish Guiana, since the expeditions of Iturria and Solano, to reach and to pass the Pacaraima mountains, have only produced very inconsiderable results. When the Spaniards, in travelling to the missions of the Catalonian Capuchin monks of Barceloneta at the confluence of the Caroni and the Rio Paragua, ascended the latter river, in going southward, to its junction with the Paraguamusi, they founded at the site of the latter junction the mission of Guirion, which at first: received the pompous name of Ciudad de Guirion. I place it in about $4 \frac{1}{2}^{\circ}$ of North latitude. From thence the governor Centurion, stimulated by the exaggerated accounts given by two Indian chiefs, Paranacare and Arimuicapi, of the powerful nation of the Ipurucotos, to search for el Dorado, prosecuted what were then called spiritual conquests still farther, and founded beyond the Pacaraima mountains the two villages of Santa Rosa and San Bautista de Caudacacla; the former on the higher eastern bank of the Uraricapara, a tributary of the Uraricuera which in the narrative of Rodriguez I find called Rio Curaricara; and the latter six or seven German (24 or 28 English) geographical miles farther to the east south-east. The astronomer of the Portuguese Boundary Commission, Don Antonio Pires de Sylva Pontes Leme, captain of a frigate, and the captain of engineers, Don Ricardo Franco d'Almeida de Serra, who between 1787 and 1804 surveyed with the greatest care the whole course of the Rio Branco and its upper branches, call the western. 
most part of the Uraricapara "the Valley of Inundation." They place the Spanish mission of Santa Rosa in $3^{\circ} .46^{\prime} \mathrm{N}$. lat., and point out the route which leads from thence northward across the chain of mountains to the Caño Anocapra, an affluent of the Paraguamusi, by means of which one passes from the basin of the Rio Branco to that of the Caroni. Two maps of these Portuguese officers, which contain the whole details of the trigonometrical survey of the windings of the Rio Branco, the Uraricuera, the Tacutu, and the Mahu, have been kindly communicated to Colonel Lapie and myself by the Count of Iinhares. These valuable unpublished documents, of which I have made use, are in the hands of the learned geographer who began a considerable time ago to have them engraved at his own expense. The Portuguese sometimes give the name of Rio Parime to the whole of the Rio Branco, and sometimes confine that denomination to one branch or tributary, the Uraricuera, below the Caño Mayari and above the old mission of San Antonio. As the words Paragua and Parime signify water, great water, lake, or sea, it is not surprising to find them so often repeated among nations at a distance from each other, the Omaguas on the Upper Marañon, the Western Guaranis, and the Caribs. In all parts of the world, as I have already remarked, the largest rivers are called by those who dwell on their banks " the River," without any distinct and peculiar appellation. Paragua, the name of a branch of the Caroni, is also the name given by the natives to the Upper Orinoco. The name Orinucu is Tamanaki; and Diego de Ordaz first heard it pronounced in 1531, when he 
ascended the river to the mouth of the Meta. Besides the "Valley of Inundation," above spoken of, we find other large lakes or expanses of water between the Rio Xumuru and the Parime. One of these belongs to the Tacutu river, and the other to the Uraricuera. Even at the foot of the Pacaraima monntains the rivers are subject to great pericdical overflows; and the Lake of Amucu, which will be spoken of more in the sequel, imparts a similar character to the country at the commencement of the plains. The Spanish missions of Santa Rosa and San Bautista de Caudacacla or Cayacaya, founded in the years 1770 and 1773 by the Governor Don Manuel Centurion, were destroyed before the close of the century, and since that period no fresh attempt has been made to penetrate from the basin of the Caroni to the southern declivity of the Pacaraima mountains.

The territory east of the valley of the Rio Branco has of late years been the subject of some successful examination. Mr. Hillhouse navigated the Massaruni as far as the bay of Caranang, from whence, he says, a path would have conducted the traveller in two days to the sources of the Massaruni, and in three days to streams flowing into the Rio Branco. In regard to the windings of the great river Massaruni, described by Mr. Hillhouse, that gentleman remarks, in a letter written to me from Demerara (January 1, 1831), that "the Massaruni beginning from its source flows first to the West, then to the North for one degree of latitude, afterwards almost 200 English miles to the East, and finally North and N.N.E. to its junction with the Essequibo." As Mr. Hillhouse was unable to reach 
the southern declivity of the Pacarima chain, he was not acquainted with the Amucu Lake: he says himself, in his printed account, that "from the information he had gained from the Accaouais, who constantly traverse all the country between the shore and the Amazons river, he had become satisfied that there is no lake at all in these districts." This statement occasioned me some surprise, as it was in direct contradiction to the views which I had formed respecting the Lake of Amucu, from which the Caño Pirara flows according to the narratives of Hortsmann, Santos, and Rodriquez, whose accounts inspired me with the more confidence because they agree entirely with the recent Portuguese manuscript maps. Finally, after five years of expectation, Sir Robert Schomburgk's journey has dispelled all doubts.

"It is difficult to believe," says Mr. Hillhouse, in his interesting memoir on the Massaruni, " that the report of a great inland water is entirely without foundation. It seems to me possible that the following circumstances may have given occasion to the belief in the existence of the fabulous lake of the Parime. At some distance from the fallen rocks of Teboco the waters of the Massaruni appear to the eye as motionless as the tranquil surface of a lake. If at a more or less remote epoch the horizontal stratum of granite at Teboco had been perfectly compact and unbroken, the waters must have stood at least fifty feet above their present level, and there would thus have been formed an immense lake, ten or twelve English miles broad and 1500 to 2000 English miles long." (Nouvelles Annales des Voyages, 1836, Sept. p. 316.) It is not solely the vast extent of this supposed 
inundation which prevents me from accepting this explanation. I have seen plains (the Llanos), where during the rainy season the overflowing of the affluents of the Orinoco annually cover with water a space of 400 German geographical square miles (equal to 6400 English geographical square miles). At such times the labyrinth of branches between the Apure, the Arauca, the Capanaparo, and the Sinaruco (see Maps 17 and 18 of my Geographical and Physical Atlas), can no longer be traced, for the separate courses are obliterated, and all appears one vast lake. But the fable of the Dorado of the Parime, and of the White Sea or Lake of the Parime, belongs historically, as I endeavoured to shew in another work thirty years ago, to an entirely different part of Guiana, namely, to the country south of the Pacaraima mountains; and originated in the shining appearance of the micaceous rocks of the Ucucuamo, the name of the Rio Parime (Rio Branco), the overflowings of the tributaries of that river, and especially the existence of the Lake of Amucu, which is in the vicinity of the Rio Rupunuwini or Rupunuri, and is connected through the Pirara with the Rio Parime.

I have seen with pleasure that the travels of Sir Robert Schomburgk have fully confirmed these early views. The part of his map which gives the course of the Essequibo and the Rupunuri is entirely new and of great geographical importance. It places the Pacaraima chain in $3^{\circ} 52^{\prime}$ to $4^{\circ}$ North latitude ( $\mathrm{I}$ had given it $4^{\circ}$ to $4^{\circ} 10^{\prime}$ ), and makes it reach the confluence of the Essequibo and the Rupunuri, in $3^{\circ} 57^{\prime} \mathrm{N}$. lat. and $60^{\circ} 23^{\prime} \mathrm{W}$. long. from Paris $\left(58^{\circ} 01^{\prime}\right.$ from Greenwich). I had placed this spot 
half a degree too far to the north. Sir Robert Schomburgk calls the last named river Rupununi, according to the pronunciation of the Macusis ; he gives as synonymes of Rupuniri, Rupunuwini and Opununy, the Carib tribes in these districts having much difficulty in articulating the sound of the letter $r$. The situation of Lake Amucu and its relations to the Mahu (Maou) and Tacutu (Tacnto) are quite in accordance with my map of Columbia in 1825. We agree equally well respecting the latitude of the lake, which I gave $3^{\circ} 35^{\prime}$, and which he finds to be $3^{\circ} 33^{\prime}$; but the Caño Pirara, (Pirarara) which connects the Lake of Amucu with the Rio Branco, flows from it to the north, instead of to the west as I had supposed. The Sibarana of my map, of which Hortsmann places the source near a fine mine of rock-crystal, a little to the north of the Cerro Ucucuamo, is the Siparuni of Schomburgk's map. His Waa-Ekuru is the Tavaricuru of the Portuguese geographer Pontes Leme; it is the tributary of the Rupunuri, which approaches nearest to the Lake of Amucu.

The following remarks from the narrative of Robert Schomburgk throw some light on the subject before us. "The Lake of Amucu," says this traveller, " is incontestably the nucleus of the Lake of Parime and the supposed White Sea. When we visited it in December and January its length scarcely amounted to a mile, and its surface was half covered with reeds." (This remark is found as early as in D'Anville's map, in 1748.) “The Pirara issues from the lake west north-west of the Indian village of Pirara, and falls into the Maou or Mahu. The last named river, from such 
information as I was able to gather, rises on the north side of the Pacaraima mountains, the easternmost part of which only attains a height of 1500 French (in round numbers 1600 English) feet. The sources of the Mahu are on a plateau, from whence it descends in a fine waterfall called Corona. We were about to visit this fall when on the third day of our excursion to the mountains the sickness of one of my companions obliged us to return to the station near Lake Amucu. The Mahu has "black" or coffee-brown water, and its current is more rapid than that of the Rupunuri. In the mountains through which it makes its way it is about 60 yards broad, and its environs are remarkably picturesque. This valley, as well as the banks of the Buroburo which flows into the Siparuni, are inhabited by the Macusis. In April the whole of the savannahs are overflowed, and present the peculiar phenomenon of the waters belonging to different river basins being intermixed and united. The enormous extent of this temporary inundation may not improbably have given occasion to the story of the Lake of Parime. During the rainy season there is formed in the interior of the country a water communication between the Essequibo, the Rio Branco, and Gran Para. Some groups of trees, which rise like oases on the sand hills of the savannahs, assume at the time of the inundation the character of islands scattered over the extensive lake; they are, no doubt, the Ipomucena Islands of Don Antonio Santos."

In D'Anville's manuscripts, which his heirs have kindly permitted me to examine, I find that the surgeon Hortsmann, of Hildesheim, who described these countries with great care, 
saw a second Alpine lake, which he places two days' journey above the confluence of the Mahu with the Rio Parime (Tacutu?). It is a lake of black water on the top of a mountain. He distinguishes it clearly from the Lake of Amucu, which he describes as "covered with reeds." The narratives of Hortsmann and Santos are as far as the Portuguese manuscript maps of the Bureau de la Marine at Rio Janeiro from indicating or admitting a constant connection between the Rupunuri and the Lake of Amucu. In D'Anville's maps the rivers are better drawn in the first edition of his South America, published in 1748, than in the more widely circulated edition of 1760 . Schomburgk's travels have completely established this general independence of the basins of the Rupunuri and the Essequibo; but he remarks that during the rainy season the Rio Waa-Ekuru, a tributary of the Rupunuri, is in connection with the Caño Pirara. Such is the state of these river basins, which are, as it were, still imperfectly developed, and are almost entirely without separating ridges.

The Rupunuri and the village of Anai (lat. $3^{\circ} 56^{\prime}$, long. $\left.58^{\circ} 34^{\prime}\right)$, are at present recognised as the political boundary between the British and the Brazilian territories in these uncultivated regions. Sir Robert Schomburgk makes his chronologically determined longitude of the Lake of Amucu depend on the mean of several lunar distances (East and West) measured by him during his stay at Anai, where he was detained some time by severe illness. His longitudes for these points of the Parime are in general a degree more easterly than the longitudes of my map of Columbia. I am far from throwing any doubt on the observations of lunar 
distances taken at Anai, and would only remark that their calculation is important if it is desired to carry the comparison from the Lake of Amucu to Esmeralda, which I found in long. $68^{\circ} 23^{\prime} 19^{\prime \prime} \mathrm{W}$. from Paris (66 $26^{\circ} 19^{\prime \prime}$ Gr.)

We see, then, the great Mar de la Parima,-which was so difficult to displace from our maps that, after my return from America, it was still set down as having a length of 160 English geographical miles,-reduced by the result of modern researches to the little Lake of Amucu, of two or three miles circumference. The illusions cherished for nearly two centuries (several hundred lives were lost in the last Spanish expedition for the discovery of el Dorado, in 1775), have thus finally terminated, leaving some results of geographical knowledge as their fruit. In 1512, thousands of soldiers perished in the expedition undertaken by Ponce de Leon for the discovery of the "Fountain of Youth," supposed to exist in one of the Bahama Islands called Bimini, and which is not to be found on our maps. This Expedition led to the conquest of Florida, and to the knowledge of the great current of the Gulf Stream, which issues forth through the Bahama channel. The thirst for treasures, and the desire of renovated youth, stimulated with nearly equal force the passions and cupidity of the nations of Europe.

(10) p. 216.- "The Piriguao, one of the noblest of palm trees."

Compare Humboldt, Bonpland, and Kunth, Nova Genera Plant. æquinoct. T. i. p. 315. 


\section{(11) p. 229.- "The vault or cemetery of an extinct nation."}

During the period of my stay in the forests of the Orinoco, these caves of bones were examined by order of the Court. The Missionary of the Cataracts had been unjustly accused of having discovered in the caves treasures which had been hidden there by the Jesuits previous to their flight. 



\section{THE NOCTURNAL LIFE OF ANIMALS}

IN THE

\section{PRIMEVAL FOREST.}





\title{
THE NOCTURNAL LIFE OF ANIMALS
}

\author{
IN THE
}

\section{PRIMEVAL FOREST.}

If the vivid appreciation and sentiment of nature which differ so greatly in nations of different descent, and if the natural character and aspect of the countries which those nations now inhabit, or which have been the seene of their earlier wanderings or abode, have rendered different languages more or less rich in well defined and characteristic expressions denoting the forms of mountains, the state of vegetation, the appearance of the atmosphere, and the contour and grouping of the clouds, it is also true that long use, and perhaps their arbitrary employment by literary men, have diverted many such words from their original meaning. Terms have been gradually regarded as synonymous which ought to have been preserved distinct; and thus languages have lost part of the vigour and the graee, as well as the fidelity, which they might otherwise have been capable of imparting to descriptions of natural scenery and of the characteristic physiognomy of a landscape. With the view of shewing how much an intimate acquaintance and contact with nature, and the wants and necessities of a laborious nomade life, may increase the riches of a 
language, I would recall the numerous characteristic appellations which may be used in Arabic ( ${ }^{1}$ ) and in Persian to distinguish plains, steppes, and deserts, according as they are quite bare, covered with sand, broken by tabular masses of rock, or interspersed with patches of pasturage, or with long tracts occupied by social plants. Scarcely less striking is it to observe in the old Castilian idiom $\left({ }^{2}\right)$ the many expressions afforded for describing the physiognomy of mountain-masses, and more particularly for designating those features which, recurring in every zone of the earth's surface, announce from afar to the attentive beholder the nature of the rock. As the declivities of the Andes, of Peru, Chili, and Mexico, and the mountainous parts of the Canaries, the Antilles and the Philippines, are all inhabited by men of Spanish descent, and as these are the parts of the earth where, (with the exception, perhaps, of the Himalaya and the Thibetian Highlands), the manner of jife of the inhabitants is most affected by and dependent on the form of the earth's surface, so all the expressions which the language of the mother country afforded for denoting the forms of mountains in trachytic, basaltic, and porphyritic districts, as well as in those where schists, limestones, and sandstone are the prevailing rocks, have been happily preserved in daily use. Under such influences even newly formed words become part of the common treasure. Speech is enriched and animated by everything that tends to and promotes truth to nature, whether in rendering the impressions received through the senses from the contemplation of the external world, or in 
expressing thoughts, emotions, or sentiments wnich have their sources in the inner depths of our being.

In descriptions of natural objects or scenery, both in the manner of viewing the phenomena, and in the choice of the expressions employed to describe them, this truth to nature must ever be kept in view as the guiding aim : its attainment will be at once most easily and most effectually secured by simplicity in the narration of what we have ourselves beheld or experienced, and by limiting and individualising the locality with which the narrative is connected. Generalisation of physical views, and the statement of general results, belong rather to the "study of the Cosmos," which, indeed, must ever continue to be to us a science of Induction; but the animated description of organic forms (plants and animals) in their local and picturesque relations to the varied surface of the earth (as a small fragment of the whole terrestrial life) affords materials towards the study of the Cosmos, and also tends to advance it by the stimulus or impulse imparted to the mind when artistic treatment is applied to phenomena of nature on a great scale:

Among such phenomena must certainly be classed the vast forest region which, in the tropical portion of South America, fills the great connected basins of the Orinoco and the Amazons. If the name of primeval forest, or "Urwald," which has of late years been so prodigally bestowed, is to be given to any forests on the face of the earth, none can claim it perhaps so strictly as the region of which we are speaking. The term "Urwald," 
primitive or primeval forest, as well as Urseit and Urvolk,primitive age, primitive nation,-are words of rather indefinite meaning, and, for the most part, only relative import. If this name is to be given to every wild forest full of a thick growth of trees on which Man has never laid a destroying hand, then the phenomenon is one which belongs to many parts of the temperate and cold zones. But if the character of the "Urwald" is that of a forest so truly impenetrable, that it is impossible to clear with an axe any passage between trees of eight or twelve feet diameter for more than a few paces, then such forests belong exclusively to the tropical regions. Nor is it by any means, as is often supposed in Europe, only the interlacing "lianes" or climbers which make it impossible to penetrate the forest; the "lianes" often form only a very small portion of the underwood. The chief obstacle is presented by an undergrowth of plants filling up every interval in a zone where all vegetation has a tendency to become ligneous. An impatient desire for the fulfilment of a long cherished wish may sometimes have led travellers who have only just landed in a tropical country, or perhaps island, to imagine that although still in the immediate vicinity of the sea-shore they had entered the precincts of a primeval forest, or "Urwald," such as I have described as impenetrable. In this they deceived themselves ; it is not every tropical forest which is entitled to an appellation which I have scarcely ever used in the narrative of my travels; although I believe that of all investigators of nature now living, Bonpland, Martius, 
Poppig, Robert and Richard Schomburgk, and myself, are those who have spent the longest period of time in primeval forests in the interior of a great continent.

Rich as is the Spanish language, (as I have already remarked), in appellations of distinct and definite meaning in the description of nature, yet the same word "Monte" is employed for mountain and forest, for cerro, (montaña) and for selva. In an inquiry into the true breadth and greatest easterly extension of the chain of the Andes, I have shewed how this two-fold signification of the word "monte" led to the introduction, in a fine and extensively circulated English map of South America, of high mountain ranges, where, in reality, only plains exist. When the Spanish map of La Cruz Olmedilla, which has served as the foundation of so many other maps, shewed "Montes de Cacao," (3) " cacao woods," Cordilleras were made to rise although the cacao seeks only the lowest and hottest localities.

If we comprehend in one general view the wooded region which includes the whole of the interior of South America, from the grassy steppes of Venezuela (los Llanos de Caracas) to the Pampas of Buenos Ayres, or from $8^{\circ}$ North to $19^{\circ}$ South latitude, we shall perceive that this connected forest of the tropical zone has an extent unequalled in any other portion of the earth's surface. Its area is about twelve times that of Germany. Traversed in all directions by systems of rivers, in which the minor and tributary streams sometimes exceed our Rhine or our Danube in the abundance of their waters, it owes 
the wonderful luxuriance of the growth of its trees to the combined influence of great moisture and high temperature. In the temperate zone, and especially in Europe and Northern Ası, forests may be named from particular genera or species, which, growing together as social plants, (plantæ sociales) form separate and distinct woods. In the northern forests of Oaks, Pines, and Birches, and in the eastern forests of Limes or Linden trees, usually only one species of Amentaceæ, Coniferæ, or Tiliaceæ, prevails or is predominant; sometimes a single species of Needle-trees is intermingled with the foliage of trees of other classes. Tropical forests, on the other hand, decked with thousands of flowers, are strangers to such uniformity of association; the exceeding variety of their flora renders it vain to ask of what trees the primeval forest consists. A countless number of families are here crowded together, and even in small spaces individuals of the same species are rarely associated. Each day, and at each change of place, new forms present themselves to the traveller, who, however, often finds that he cannot reach the blossoms of trees whose leaves and ramifications had previously arrested his attention.

The rivers, with their countless lateral arms, afford the only routes by which the country can be traversed. Between the Orinoco, the Cassiquiare, and the Rio Negro, astronomical observations, and where these were wanting, determinations by compass of the direction of the rivers, respectively shewed us that two lonely mission villages might be only a few miles apart, and yet that the monks when they 
wished to visit euch other could only do so by spending a day and a half in following the windings of small streams, in canoes hollowed out of the trunks of trees. A striking evidence of the impenetrability of particular parts of the forest is afforded by a trait related by an Indian of the habits of the large American tiger, or panther-like jaguar. While in the Llanos of Varinas and the Meta, and in the Pampas of Buenos Ayres, the introduction of European cattle, horses, and mules has enabled the beasts of prey to find an abundant subsistence,-so that since the first discovery of America their numbers have increased exceedingly in those extended and treeless grassy steppes,- their congeners in the dense forests around the sources of the Orinoco lead a very different and far less easy life. In a bivouac near the junction of the Cassiquiare with the Orinoco we had had the misfortune of losing a large dog, to which we were much attached, as the most faithful and affectionate companion of our wanderings. Being still uncertain whether he had been actually killed by the tigers, a faint hope of recovering him induced us, in returning from the mission of Esmeralda through the swarms of musquitoes by which it is infested, to spend another night at the spot where we had so long sought him in vain. We heard the cries of the jaguar, probably the very individual which we suspected of the deed, extremely near to us; and as the clouded sky made astronomical observations impossible, we passed part of the night in making our interpreter (lenguaraz) repeat to us the accounts given by our native boat's crew of the tigers of the country. 
The "black jaguar" was, they said, not unfrequently found there; it is the largest and most bloodthirsty variety, with black spots scarceiy distinguishable on its deep darkbrown skin. It lives at the foot of the mountains of Maraguaca and Unturan. One of the Indians of the Durimund tribe then related to us that jaguars are often led, by their love of wandering and by their rapacity, to lose themselves in such impenetrable parts of the forest that they can no longer hunt along the ground, and live instead in the trees, where they are the terror of the families of monkeys and of the prehensile-tailed viverra, the Cercoleptes. I borrow these notices from journals written at the time in German, and which were not entirely exhausted in the Narrative of my Travels, which I published in the French language. They contain a detailed description of the nocturnal life, or perhaps I might rather say the nocturnal voices, of the wild animals in the forests of the torrid zone ; which appears to me particularly suited to form part of a work bearing the title of the present volumes. That which is written down on the spot, either in the immediate presence of the phenomena, or soon after the reception of the impressions which they produce, may at least lay claim to more life and freshness than can be expected in recollections.

Descending from West to East the Rio Apure, the overflowings of whose waters and the inundations produced by them were noticed in the chapter on Steppes and Deserts, we arrived at its junction with the Orinoco. It was the season of low water, and the average breadth of the Apure was only a little more than twelve hundred English feet, yet I found 
the Orinoco at the confluence of the two rivers, not far from the granite rock of Curiquima, where I was able to measure a base line, still upwards of 11430 French (12180 English) feet wide. Yet this point, $i . e$. the Rock of Curiquima, is four hundred geographical miles in a straight line from the sea and from the Delta of the Orinoco. Part of the plains watered by the Apure and the Pagara are inhabited by tribes of the Yaruros and Achaguas, who, as they persist in maintaining their independence, are called savages in the mission villages established by the monks : their manners, however, are scarcely more rude than those of the Indians of the villages,-who, although baptized and living " under the bell" (baxo la compana), are still almost entirely untaught and uninstructed.

On leaving the Island del Diamante, in which Zambos who speak Spanish cultivate sugar-canes, we entered on scenes of nature characterized by wildness and grandeur. The air was filled with countless flocks of flamingoes (Phœnicopterus) and other water birds, which appeared against the blue sky like a dark cloud with continually varying outlines. The river had here narrowed to between 900 and 1000 feet, and flowing in a perfectly straight line formed a kind of canal enclosed on either side by dense wood. The margin of the forest presents at this part a singular appearance. In front of the almost impenetrable wall of giant trunks of Cosalpinia, Cedrela, and Desmanthus, there rises from the sandy river beach, with the greatest regularity, a low hedge of Sauso, only four feet high, consisting of a small shrub, Hermesia castaneifolia, which forms a new 
genus $\left({ }^{4}\right)$ of the family of Euphorbiacex. Some slender thorny palms, called by the Spaniards Piritu and Coroso (perhaps species of Martinezia and Bactris), stand next; and the whole resembles a close, well-pruned garden hedge, having only occasional openings at considerable distances from each other, which have doubtless been made by the larger four-footed beasts of the forest to gain easy access to the river. One sees, more especially in the early morning and at sunset, the American tiger or jaguar, the tapir, and the peccary, lead their young through these openings to the river to drink. When startled by the passing canoe, they do not attempt to regain the forest by breaking forcibly through the hedge which has been described, but one has the pleasure of seeing these wild animals stalk leisurely along between the river and the hedge for four or five hundred paces, until they have reached the nearest opening, when they disappear through it. In the course of an almost uninterrupted river navigation of 1520 geographical miles on the Orinoco to near its sources, on the Cassiquiare, and on the Rio Negro,-and during which we were confined for seventy-four days to a small canoe,-we enjoyed the repetition of the same spectacle at several different points, and I may add, always with new delight. There came down together, to drink, to bathe, or to fish, groups consisting of the most different classes of animals, the larger mammalia, being associated with many coloured herons, palamedeas, and proudly-stepping curassow and cashew birds (Crax Alector and C. Pauxi). "Es como en el Paraiso;" it is here as in Paradise, said, with a pious air, our 
steersman, an old Indian who had been brought up in the house of an ecclesiastic. The peace of the golden age was, however, far from prevailing among the animals of this American paradise, which carefully watched and avoided each other. The Capybara, a Cavy three or four feet long, (a magnified repetition of the Brazilian Cavy, Cavia aguti), is devoured in the river by the rrocodiles, and on shore by the tiger. It.runs so indifferently that we were several times able to catch individuals from among the numerous herds which presented themselves.

Below the mission of Santa Barbara de Arichuna we passed the night as usual, under the open sky, on a sandy flat on the bank of the Rio Apure closely bordered by the impenetrable forest. It was not without difficulty that we succeeded in finding dry wood to kindle the fire with which it is always customary in that country to surround a bivouac, in order to guard against the attacks of the jaguar. The night was humid, mild, and moonlight. Several crocodiles approached the shore; I think I have observed these animals to be attracted by fire, like our cray-fish and many other inhabitants of the water. The oars of our boat were placed upright and carefully driven into the ground, to form poles from which our hammocks could be suspended. Deep stillness prevailed; only from time to time we heard the blowing of the fresh-water dolphins $\left(^{5}\right)$ which are peculiar to the Orinoco net-work of rivers (and, according to Colebrooke, to the Ganges as far as Benares), which followed each other in long lines.

Soun after 11 o'clock such a disturbance began to be 
heard in the adjoining forest, that for the remainder of the night all sleep was impossible. The wild cries of animals appeared to rage throughout the forest. Among the many voices which resounded together, the Indians could only recognise those which, after short pauses in the general uproar, were first heard singly. There was the monotonous howling of the aluates (the howling monkeys); the plaintive, soft, and almost flute-like tones of the small sapajous; the snorting grumblings of the striped nocturnal monkey ( ${ }^{6}$ ) (the Nyctipithicus trivirgatus, which I was the first to describe); the interrupted cries of the great tiger, the cuguar or maneless American lion, the peccary, the sloth, and a host of parrots, of parraquas, and other pheasant-like birds. When the tigers came near the edge of the forest, our dog, which had before barked incessantly, came howling to seek refuge under our hammocks. Sometimes the cry of the tiger was heard to proceed from amidst the high branches of a tree, and was in such case always accompanied by the plaintive piping of the monkeys, who were seeking to escape from the unwonted pursuit.

If one asks the Indians why this incessant noise and disturbance arises on particular nights, they answer, with a smile, that "the animals are rejoicing in the bright moonlight, and keeping the feast of the full moon." To me it appeared that the scene had probably originated in some accidental combat, and that hence the disturbance had spread to other animals, and thus the noise had increased more and more. The jaguar pursues the peccaries and tapirs, and these, pressing against each other in their flight, 
break through the interwoven tree-like shrubs which impede their escape; the apes on the tops of the trees, being frightened by the crash, join their cries to those of the larger animals; this arouses the tribes of birds, who build their nests in communities, and thus the whole animal world becomes in a state of commotion. Longer experience taught us that it is by no means always the celebration or the brightness of the moon which disturbs the repose of the woods: we witnessed the same occurrence repeatedly, and found that the voices were loudest during volent falls of rain, or when, with loud peals of thunder, the flashing lightning illuminated the deep recesses of the forest. The good-natured Franciscan monk, who, although he had been suffering for several months from fever, accompanied us through the Cataracts of Atures and Maypures to San Carlos on the Rio Negro, and to the Brazilian boundary, used to say, when fearful on the closing in of night that there might be a thunder-storm, "May Heaven grant a quiet night both to us and to the wild beasts of the forest !"

Scenes, such as those I have just described, were wonderfully contrasted with the stillness which prevails within the tropics during the noontide hours of a day of more than usual heat. I borrow from the same journal the recollections of a day at the Narrows of Baraguan. At this part of its course the Orinoco forces for itself a passage through the western portion of the Parime Mountains. What is called at this remarkable pass a "Narrow" (Angostura del Baraguan), is still a bed or water-basin of 890 toises ( 5690 English feet) in breadth. On the naked rocks which formed 
the shores we saw only, besides an old withered stem of Aubletia (Apeiba tiburba), and a new Apocinea (Allamanda salicifolia), a few silvery croton shrubs. A thermometer observed in the shade, but brought within a few inches of the towering mass of granite rock, rose to above $40^{\circ}$ Reaumur (122 Fah.) All distant objects had wave-like undulating outlines, the effect of mirage; not a breath of air stirred the fine dust-like sand. The sun was in the zenith, and the flood of light which he poured down upon the river, and which, from a slight rippling movement of the waters, flashed sparkling back, rendered still more sensible the red haze which veiled the distance. All the naked rocks and boulders around were covered with a countless number of large thick-scaled iguanas, gecko-lizards, and variously spotted salamanders. Motionless, with uplifted heads and open mouths, they appeared to inhale the burning air with ecstacy. At such times the larger animals seek shelter in the recesses of the forest, and the birds hide themselves under the thick foliage of the trees, or in the clefts of the rocks; but if, in this apparent entire stillness of nature, one listens for the faintest tones which an attentive ear can seize, there is perceived an all-pervading rustling sound, a humming and fluttering of insects close to the ground, and in the lower strata of the atmosphere. Every thing announces a world of organic activity and life. In every bush, in the cracked bark of the trees, in the earth undermined by hymenopterous insects, life stirs audibly. It is, as it were, one of the many voices of Nature, heard only by the sensitive and reverent ear of her true votaries. 


\section{ANNOTATIONS AND ADDITIONS.}

(1) p. 260.- "Characteristic names in Arabic and Persian."

More than twenty different terms might be cited as used by Arabs in speaking of steppes, (tanufah), to denote deserts without water, entirely bare, covered with siliceous sand, or interspersed with spots affording some pasture: (sahara, kafr, mikfar, tih, and mehme.) Sahl, is a low plain; dakkah, a desolate elevated plain. In Persian, "beyaban" signifies the arid sandy desert, - as do the Mogul "gobi," and the Chinese "han-hai," and "scha-mo." "Yaila" is a steppe covered rather with grasses or herbage than with herbaceous plants; so are also the Mogul "küdah," and the Turkish " tala," or " tschol," and the Chinese "huang." "Deshti-reft" is an elevated plain devoid of vegetation. (Humboldt, Relation hist. T. ii. p. 158.)

(2) p. 260.- "In the old Castilian idiom."

Pico, picacho, mogote, cucurucho, espigon, loma tendida, mesa, panecillo, farallon, tablon, peña, peñon, peñasco, peñoleria, roca partida, laxa, cerro, sierra, serrania, cordillera, monte, montaña, montañuela, cadena de montes, los altos, malpais, reventazon, bufa, \&c.

vol. I. 
(3) p. 263.- "Where the map had exhibited Montes de Cacau."

On the range of hills which had been converted into the lofty Andes de Cuchao, see my Rel. hist. T. iii. p. 238.

\section{(4) p. 268.- "Hermesia."}

The genus Hermesia, the Sauso, has been described by Bonpland, and figured in our Plantes equinoxiales, T. i. p. 162, tab. xlvi.

\section{(5) p. 269.—“ The fresh-water dolphin."}

These are not sea-dolphins, ascending the rivers for a great distance, as is done by some species of Pleuronectes (flat fish, which always have both eyes on one side of the body) ; for example, the Limande (Pleuronectes Limanda), which comes up the Loire to Orleans. Some sea forms of fish, as dolphins and skates, are repeated in the great rivers of both continents. The fresh-water dolphin of the Apure and the Orinoco differs specifically from the Delphinus gangeticus, as well as from all, sea-dolphins. See my Rel. hist. T. ii. pp. 223, 239, 406-413.

\section{(6) p. 270.- "The striped nocturnal monkey."}

This is the Douroucouli, or Cusi-cusi of the Cassiquiare, described by me as Simia trivirgata in my Recueil d'Observations de Zoologie et a’'Anatomie comparée, T. i. p.306311 , tab. xxviii., the plate being taken from a drawing made by myself from the living animal. We subsequently 
saw this nocturnal monkey living in the menagerie of the Jardin des Plantes at Paris. (See the work above cited, T. ii. p. 340.) Spix also found this remarkable little animal on the Amazons river, and called it Nyctipithecus vociferans.

Potsdam, June 1849. 



\section{HYPSOMETRIC ADDENDA.}

I AM indebted to Mr. Pentland (whose scientific labours have thrown so much light on the geology and geography of Bolivia) for the following determinations, which he communicated to me in a letter written from Paris, in October 1848, after the publication of his great map :-

Nevado of Sorata, or

Ancohuma.

S. lat.

South Peak.....15 $15^{\circ} 51^{\prime} 33^{\prime \prime}$

North Peak.....15 $15^{\circ} 49^{\prime} 18^{\prime \prime}$

Illimani.

South Peak.....16 $16^{\circ} 38^{\prime} 52^{\prime \prime}$

Middle Peak ....16 $36^{\circ} 26^{\prime \prime}$

North Peak......16 $36^{\circ} 50^{\prime \prime}$
Long. from Greenwich. $68^{\circ} 33^{\prime} 55^{\prime \prime}$ $68^{\circ} 33^{\prime} 52^{\prime \prime}$

$67^{\circ} 49^{\prime} 18^{\prime \prime}$

$67^{\circ} 49^{\prime} 17^{\prime \prime}$

$67^{\circ} 49^{\prime} 39^{\prime \prime}$
Height in English Feet.

$21286^{\circ}$

21043

21145

21094

21060

The heights (with the exception of the unimportant difference of a few feet in the South Peak of Illimani) are the same as those given in the map of the Lake of Titicaca. A sketch of the last-named mountain (Illimani), as it shews itself in all its majesty from $\mathrm{La} \mathrm{Paz}$, has been given by $\mathrm{Mr}$. Pentland in the Journal of the Royal Geographical Society, Vol. V. (1835), p. 77. This was five years after the publication of the first measurements in the Annuaire du Bureau des Longitudes for 1830, p. 323, which results I myself 
hastened to make known in Germany. (Hertha, Zeitschrift für Erd und Völkerkunde, von Berghaus, Bd. xiii. 1829, S. 3-29.) The Nevado de Sorata is to the east of the village Sorata, or Esquibel : it is called in the Ymarra language, according to Pentland, Ancomani, Itampu, and Illhampu. We recognise in "Tllimani," the Ymarra word "illi," snow.

If, however, in the eastern chain of Bolivia the Sorata was long assumed 3718 French, or 3952 English feet, and the Tllimani 2675 French, or 2851 English, feet too high, there are in the western chain of the same country, according to Pentland's map of Titicaca (1848), four peaks to the east of Arica and between lat. $18^{\circ} 7^{\prime}$ and $18^{\circ} 25^{\prime}$, all of which are higher than Chimborazo, which is 21422 English or 20100 French feet. These four peaks are-

Pomarape . . . . 21700 English feet, or 20360 French feet. Gualateiri . . . . 21960 " " " 20604 " " Parinacota . . . . 22030 " " 20670 " " Sahama . . . . " 22350 " 20971 " "

Berghaus has applied to the eastern and western chains of the Andes of Bolivia the investigation published by me in the Annales des Sciences Naturelles, T. iv. 1825, p. 225-253, of the proportion (very different in different mountain chains), which the general height of the ridge, the crest, or kamm (the mean height of the passes), bears to the highest summits or culminating points. He finds, following Pentland's map, the mean height of the passes in the eastern chain 12672 French, or 13502 English feet; and in the 
western chain 13602 French, or 14896 English feet. The culminating points are 19972 and 20971 French, 21286 and 22350 English feet; consequently the ratio of the height of the ridge to that of the culminating point is, in the eastern chain, as $1: 1.57$, and in the western chain as 1 : 1.54. (Berghaus, Zeitschrift für Erdkunde, Band. ix. $\mathrm{S} .322-326)$. This ratio, which is, as it were, the measure of the subterranean elevating force, is very similar to that which exists in the Pyrenees, but very different from the Alps, where the mean height of the passes is less as compared with Mont Blanc. The ratios are, in the Pyrenees, $=1: 1.43$, and in the Alps, =1 : 2.09.

But, according to Fitz Roy and Darwin, the height of the Sahama is still surpassed by 796 French, or 850 English feet, by that of the volcano of Aconcagua, on the north east of Valparaiso, in Chili, in S. lat. $32^{\circ} 39^{\prime}$. The officers of the Adventure and Beagle, in Fitz Roy's Expedition, found, in August 1835, the summit of Acongagua between 23000 and 23400 English feet. If we take it at 23200 (equal to 21767 Paris feet), this volcano would be 1667 French, or 1777 English, feet higher than the Chimborazo. (Fitz Roy, Voyages of the Adventure and Beagle, 1839, Vol. ii. p. 481 ; Darwin, Journal of Researches, 1845, pp. 223 and 291.) According to more recent calculations, the height of Acongagua is given as 22431 French, or 23907 English feet. (Mary Somerville, Physical Geogr. 1849, Vol. ii. p. 425.)

Our knowledge of the systems of mountains which, north of the parallels of $30^{\circ}$ and $31^{\circ} \mathrm{N}$. lat., are called the Rocky 
Mountains and the Sierra Nevada of California, has received most important additions, geologically, botanically, hypsometrically, and geographically by astronomical determinations of position, from the excellent works of Charles Frémont (Geographical Memoir upon Upper California, an illustration of his Map of Oregon and California, 1848) ; of Dr. Wislizenus (Memoir of a Tour to Northern Mexico, connected with Col. Doniphan's Expedition, 1848) ; and of Lieutenants Abert and Peck (Expedition on the Upper Arkansas, 1845; and Examination of New Mexico in 1846 and 1847.) There prevails throughout these different North American works a true scientific spirit, which is deserving of the greatest commendation. The remarkable elevated plain, which rises to an uninterrupted height of four or five thousand French (4260 and 5330 English) feet, between the Rocky Mountains and the Sierra Nevada of California, of which I have spoken in p. 44, and which is called the Great Basin, forms an inland closed river basin, and has hot springs and salt lakes. None of its rivers,Bear River, Carson River, and Humboldt River,-find their way to the sea. The Lake, which I was led by combinations and inferences to represent, in the great Map of Mexico drawn by me in 1804, under the name of Lake Timpanogos, is the great Salt Lake of Frémont's Map : it is sixty geographical miles long from north to south, and ten broad; and it communicates with the fresh water lake of Utah, which is situated at a higher level, and receives the Timpanogos or Timpanaozu River, which enters it from the eastward, in lat. $40^{\circ} 13^{\prime}$. The circumstance of the Timpano- 
gos Lake of my map not having been placed by me suffciently far to the north and west, is to be attributed to the entire want, at that time, of any astronomical determinations of the position of Santa Fé, in New Mexico. The error amounts, for the western margin of the lake, to almost 50 minutes of arc; a difference of absolute longitude which will appear less surprising, if it is remembered that my itinerary map of Guanaxuato could only be based for 15 degrees of latitude on compass surveys, or compass directions, for which I was indebted to Don Pedro de Rivera. (Humboldt, Essai polit. sur la Nouvelle Espagne, T. i. pp. 127-136.) These directions being differently combined by my early deceased fellow-labourer, Herr Friesen, and myself, gave him as the result of his combinations $107^{\circ} 58$ from Paris as the longitude of Santa Fé, and to me as the result of mine, $107^{\circ} 13^{\prime}$. According to actual astronomical determinations since obtained, the true longitude appears to be $108^{\circ} 22^{\prime} \mathrm{W}$. of Paris, or $106^{\circ} 00^{\prime} \mathrm{W}$. of Greenwich. The relative position of the beds of fossil salt-found in "thick strata of red clay," on the south east of the islandstudded Great Salt Lake (my Laguna de Timpanogos), and not far from the present Fort Mormon and the Utah Lakewas given with perfect correctness in my large map of Mexico. I may refer on this point to the latest evidence of the traveller who made the first well-assured determinations of geographical position in that district:- "The mineral or rock salt, of which a specimen is placed in Congress Library, was found in the place marked by Humboldt in his map of 
New Spain (northern half), as derived from the journal of the missionary Father Escalante, who attempted (1777) to penetrate the unknown country from Santa Fé of New Mexico to Monterey of the Pacific Ocean. South-east of the Lake Timpanogos is the chain of the Wha-satch Mountains ; and in this, at the place where Humboldt has written Montagnes de sel gemme, this mineral is found." (Frémont, Geogr. Mem. of Upper California, 1848, pp. 8 and 67 ; compare Humboldt, Essai politique, T. ii. p. 261.)

A great historical interest attaches to this part of the highland, and more particularly to the country round the Lake of Timpanogos, which is perhaps the same with the Lake of Teguayo, the ancestral seat of the Aztecs. In their migration from Aztlan to Tula, and to the Valley of Tenochtitlan (Mexico), this people made three halting places or stations, at which the ruins of the Casas grandes are still to be seen. The first sojourn of the Aztecs was at the Lake of Teguayo, the second on the Rio Gila, and the third not far from the Presidio de Llanos. Lieutenant Abert found on the banks of the Gila the same immense number of fragments of pottery ornamented with painting, and scattered over a considerable tract of ground, which had astonished the missionaries Francisco Garces and Pedro Fonte in that locality. These remains of the products of human skill are supposed to indicate the existence of a former higher civilisation in these now solitary regions. Remains of buildings in the singular style of architecture of the Aztecs, and of their houses of seven stories, are also found far to the east. 
ward of the Rio Grande del Norte; for example, in Taos. (Compare Abert's Examination of New Mexico, in the Documents of Congress, No. 41, pp. 489 and 581-605, with my Essai pol. T. ii. pp. 241-244.) The Sierra Nevada of California is parallel to the Coast of the Pacific; but between the latitudes of $34^{\circ}$ and $41^{\circ}$, between San Buenaventura and the Bay of Trinidad, there runs, on the West of the Sierra Nevada, another (smaller) coast chain, of which Monte del Diablo, 3448 French, 3674 English feet high, is the culminating point. In the narrow valley, between this coast chain and the great Sierra Nevada, flow from the south the Rio de San Joaquin, and from the north the Rio del Sacramento, on the banks of which, in rich alluvial soil, are the rich gold-washings now so much resorted to.

I have already referred, p. 43, to a hypsometric levelling, and to barometric measurements made from the junction of the Kanzas River with the Missouri to the Pacific, or throughout the immense extent of 28 degrees of longitude. Dr. Wislizenus has now successfully continued the levelling began by me from the city of Mexico, in the Equinoctial Zone, to the North as far as Santa Fé del Nuevo Mexico, in lat. $35^{\circ} 38^{\prime}$. It will be seen, perhaps, with surprise, that the elevated plain which forms the broad crest of the Mexican Andes is far from sinking down, as had long been supposed, to an inconsiderable height. I give here for the first time, according to the measurements which we at present possess, the elevations of several points, forming a line of levelling from the city of Mexico to Santa Fé, which latter 
town is less than four German (sixteen English) geographical miles from the Rio del Norte.

\begin{tabular}{|c|c|c|c|}
\hline ........ & 7008 & 7490 & Ht. \\
\hline . . . . . & 6318 & 6733 & Ht. \\
\hline an Juan del Rio . . . . . . & 6090 & 6490 & Ht. \\
\hline ueretaro . . . . . . . & 5970 & 6363 & Ht. \\
\hline elaya. : . . . . . & 5646 & 6017 & Ht. \\
\hline Salamanca . . . . . . & 5406 & 5761 & Ht. \\
\hline Guanaxuato . . . . & 6414 & 6836 & Ht. \\
\hline . & 5546 & 5910 & Br. \\
\hline Villa de Leon . . . . . . . & 5755 & 133 & Br. \\
\hline Lagos . . . . . . . . . & 5983 & 6376 & Br. \\
\hline Aguas Calientes . . . . . . . & - 5875 & 6261 & Br. \\
\hline San Luis Potosi . . . . . . . . & 5714 & 6090 & Br. \\
\hline acatecas. . . . . . . & . 7544 & 8040 & Br. \\
\hline Fresnillo . . . . . . & - 6797 & 7244 & Br. \\
\hline Durango . . & - 6426 & 6848 & (Oteiza \\
\hline Parras. . . & 4678 & 4985 & Ws. \\
\hline . . . . . & 4917 & $5240^{\circ}$ & Ws. \\
\hline El Bolson de Mar & $\left\{\begin{array}{c}3600 \text { to } \\
4200\end{array}\right.$ & $\left.\begin{array}{c}3837 \text { to } \\
4476\end{array}\right\}$ & Ws \\
\hline Chihuahua & - 4352 & 4638 & Ws. \\
\hline Cosiquiriachi . . . . . . & 5886 & 6273 & Ws \\
\hline $\begin{array}{l}\text { Passo del Norte, on the Rio Grande del } \\
\text { Norte }\end{array}$ & 3557 & 3812 & Ws \\
\hline Santa Fé del Nuevo Mexico . & . 6612 & 7047 & Ws \\
\hline
\end{tabular}

The letters Ws., Br., and Ht., are placed to distinguish the barometric measurements of Dr. Wislizenus, Oberbergrath Burkart, and my own. Wislizenus has appended to his valuable memoir three vertical sections of the surface of the ground: one from Santa Fé to Chihuahua by Passo del 
Norte; one from Chihuahua to Reynosa by Parras; and one from Fort Independence (a little to the east of the Confluence of the Missouri and the Kanzas River) to Santa Fé. The calculation is founded on daily corresponding observations of the barometer, made by Engelmann at St. Louis, and by Lilly at New Orleans. If we consider that the difference of latitude between Santa Fé and Mexico is $16^{\circ}$, and that thus (apart from deviations from a straight line) the distance in the north and south direction is above 960 geographical miles, we are led to inquire whether there be in any other part of the whole globe a similar conformation of the Earth, equal in extent and elevation (between 5000 and 7000 French, or 5330 and 7460 English feet above the level of the sea) to the highland of which I have just given the levelling, and yet over which four-wheeled waggons can travel as they do from Mexico to Santa Fé. It is formed by the broad, undulating, flattened crest of the chain of the Mexican Andes, and is not the swelling of a valley between two mountain chains, as is the case in some other remarkable elevations of plain or undulating sufacein the Northern Hemisphere, in the "Great Basin" between the Rocky Mountains and the Sierra Nevada of California, in the Southern Hemisphere, in the high plain of the lake of Titicaca, between the eastern and western chains of the Andes of Bolivia,-and in Asia, in the highlands of Thibet, between the Himalaya and the Kuen-liun. 



\section{GENERAL SUMMARY}

OP THE

CONTTENTS OF THE FIRST VOLUME. 



\section{GENERAL SUMMARY}

\section{OF THE \\ CONTENTS OF VOL. I.}

Preface to the First Edition-p. vii. to p. ix.

Preface to the Second and Third Editions-p. xi. to p. xv.

Note by the Translator-p. xvii.

Steppes and Deserts-p. 1 to p. 26.

Coast chain and mountain valleys of Caraccas. Lake of Tacarigua. Contrast in respect to the luxuriance of vegetation between those districts and the treeless plains. The steppe regarded as the bottom of a Mediterranean Sea ; broken strata a little higher than the rest of the plain called "banks." General phenomena of extensive plains; the Heaths of Europe, the Pampas and Llanos of South America, the African Deserts, and the Steppes of Northern Asia. Different characters of the vegetable covering of the surface. Animal life. Pastoral nations, and their invasive migrations. $1-6$

Description of the South American plains and prairies-their extent and climate; the latter dependent on the outline of the coasts, and on the hypsometric conformation of the New Continent. Comparison with the plains and deserts of Africa . . . . 7-13

Original absence of pastoral life in America. Food furnished by the Mauritia palm; the Guaranis' huts raised on trees . 13-17 VOL. I. 
Since the discovery of America the Llanos have become more habitable. Extraordinary increase in the number of wild cattle, horses, asses, and mules. Description of the season of extreme dryness, and of the rainy season. Appearance of the surface of the ground and of the sky. Life of the animals-their sufferings, their conflicts; power of adaptation with which certain animals and plants are endowed. Jaguars, crocodiles, and electric fishes. Unequal conflict between Gymnoti and horses . . . . . 17-23

Retrospective glance at the countries surrounding the Steppes and Deserts. Forest wildernesses of the Orinoco and the Amazons. Indian tribes separated by the wonderful diversity of their languages and differences of their habits; their hardships, and frequent variance between the different tribes. Figures graven on the rocks show that these solitudes were once the seat of a degree of civilisation which has now disappeared . . . 23-26

Scientific Elucidations and Additions-p. 27 to p. 204.

The island-studded lake of Tacarigua ; its relations to the neighbouring mountain chains. Geological description. Progress of cultivation and of European civilisation. Varieties of the sugar-eane. Cacao plantations. Great fertility of soil associated within the tropics with insalubrity of atmosphere . . . . . 27-33

"Banks" or broken strata. General horizontality of the surface. Subsidences of the surface . . . . . . 33-35

Resemblance of the distant steppe to the ocean. Naked stony crust. Tabular masses of syenite; whether prejudicial to health $36-37$

General views respecting the mountain systems of North and Sonth America, embracing the most recent information. Chains running in a south-west and north-east direction in Brazil and in the 
Atlantic portion of the United States of North America. The low province of Chiquitos; small swellings of the ground constitute the division between the waters of the Guaporé and Aguapebi in $15^{\circ}$ and $17^{\circ} \mathrm{S}$. lat., and between the river basins of the Orinoco and the Rio Negro in $2^{\circ}$ and $3^{\circ}$ N. lat. . . . 37-39

Continuation of the chain of the Andes north of the isthmus of Panama (through the Aztec country, where Popocatepetl, 16626 French, or 17720 English feet high, has very recently been again ascended by Captain Stone) in the Sierra de las Grullas and the Rocky Mountains. Excellent scientific investigations of Captain Frémont. The longest barometric levelling ever made, showing a profile or vertical section of the earth's surface through a space of $28^{\circ}$ of longitude. Culmirating point of the route from the coast of the Atlantic to the Pacific. "Soulh Pass," south of the Wind River Mountains. Swelling of the ground in the Great Basin. Long contested existence of the Timpanogos Lake. Coast Chain, Maritime Alps, or Sierra Nevada of California. Voleanic eruptions. Falls of the Columbia .

General considerations on the contrasts shown by the spaces included between the central chain (the Rocky Mountains) and the diverging chains on the east and west (the Alleghanies and the Sierra Nevada of Califormia); hypsometric characters of the low eastern space, which is only from 400 to 600 French, or 426 to 639 English feet above the level of the sea, and of the arid uninhabited plain 5000 or 6000 (5330 to 6400 English) feet above the same level, called the Great Basin. Sources of the Mississipi in the Lake of Istaca according to Nicollet's highly meritorious researches. Buffalo country; Gomara's assertion of buffaloes having been formerly tamed in the northern part of Mexico . . . . 50-55

Retrospective view of the chain of the Andes from the Rocks of 
Diego Ramirez to Behring's Strait. Long circulated errors respecting the heights of mountains in the eastern chain of the Andes of Bolivia, especially the Sorata and the Illimani. Four summits of the western chain of Bolivia, which, according to Pentland's latest determinations, are higher than the Chimborazo, but are not equal in height to the still active volcano of Acongagua measured by Fitz-Roy

The African mountains of Harudsch-el-Abiad. Oases . $58-60$

West winds on the coast of the Sahara. Accumulation of sea-weed; position of the great bank of Fucus from the time of Scylax of Caryanda to that of Columbus, and to the present day.

$60-67$

Tibbos and Tuaricks. The camel and its distribution . 67-71

Mountain systems of the interior of Asia between Northern Siberia and India. Erroneous belief in the existence of a single great elevated plain called "Plateau de la Tartarie" . . 71-75

Chinese literature a rich source of orographic knowledge. Series of elevations of different highlands. Desert of Gobi. Probable mean height of Thibet. . . + . . . . 75-85

Review of the mountain systems of the interior of Asia. Chains running in the direction of the meridian; the Ural, which separates the low part of Europe from the low part of Asia, or divides into two portions the Seythian Europe of Pherecydes of Syros and of Herodotus; Bolor; Khingan and the Chinese chains, which, near the great bend in the direction of the Thibetian and AssamoBurmese river Dzangbo-tschu, run north and south. The elevations which, between $66^{\circ}$ and $77^{\circ} \mathrm{E}$. long. from Greenwich, follow the direction of meridians from Cape Comorin to the Icy Sea, alternate 
like veins or dikes in which there are faults or displacements; thus the Ghauts, the Soliman Chain, the Paralasa, the Bolor, and the Ural, succeed each other from south to north: the Bolor gave occasion among the ancients to the idea of the Imaus, which Agathodæmon supposed to be prolonged to the north into the low basin of the lower Irtysch. Parallel chains running east and west; the Altai; Thian-schan, with its active volcanoes at a distance of 1528 geographical miles from the Icy Sea at the mouth of the Obi, and of 1512 geographical miles from the Indian Sea at the mouth of the Ganges; the Kuen-lün, recognised by Eratosthenes, Marinus of Tyre, Ptolemy, and Cosmas Indicopleustes, as the longest axis of elevation in the Old World, runs between $35 \frac{1}{2}^{\circ}$ and $36^{\circ}$ of latitude in the direction of the diaphragm of Dicearchus. Himalaya. The Kuen-lün, considered as an axis of elevation, may be traced from the wall of China near Lung-tscheu through the somewhat more northerly chains of Nan-schan and Kilian-schan, through the mountain knot near the Lake called the "Starry Sea," through the Hindu-Coosh (the Parapanisus and Indian Caucasus of the ancients), and through the chain of Demawend and the Persian Elbourz, to Taurus in Lycia. Near the intersection of the Kuenlïn and the Bolor the correspondence of the direction of the axes of elevation (east and west in the Kuen-lün and the Hindu-Coosh, whereas that of the Himalaya is south-east and north-west) shows that the Hindu-Coosh is a continuation of the Kuen-lün, and not of the Himalaya. The point where the direction of the Himalaya changes to south-east and north-west from having been east and west, is about the 79th degree of east longitude from Paris $\left(81^{\circ} 22^{\prime}\right.$ Greenwich). Next to the Dhawalagiri, it is not, as has been hitherto supposed, the Jawahir which is the highest summit of the Himalaya ; that rank belonging, according to the most recent intelligence received from Dr. Joseph Hooker, to a mountain situated between Boutan and Nepaul in the meridian of Sikkim, the Kinchinjinga : the western summit of this mountain, which has been measured 
by Colonel Wangh, director of the trigonometrical survey of India, is 28178 feet, and its eastern summit 27826 feet high, according to the Journal of the Asiatic Society of Bengal, Nov. 1848 :-The mountain which is now supposed to be higher than the Dhawalagiri is figured on the frontispiece of the magnificent work of Joseph Hooker entitled "The Rhododendrons of Sikkim-Himalaya, 1849."

-Determination of the lower limits of the snow-line on the northern and southern declivities of the Himalaya; its height being on an average 3400 to 4600 French, or 3620 to 4900 English feet higher on the northern face. New data on the subject from Hodgson. Without this remarkable distribution of temperature in the upper strata of the atmosphere, the mountain plains of Western Thibet would be uninhabitable to the millions of human beings who now dwell there.

The Hiong-nu, regarded by Deguignes and Johannes Müller as a tribe of Huns, appear rather to have been one of the widely scattered tribes of the Turks of the Altai and Tang-nu mountains. The Huns, whose name was known to Dionysius Perigetes, and who are noticed by Ptolemy as Chuns (whence the later appellation of Chunigard given to a country!), are a Finnish race of the Ural mountains .

. 101-102

Figures of the sun and of animals, and other signs carved on rocks in the Sierra Parime, as well as in North America, have often been supposed to be writing . . . . . 102-104

Description of the cold mountain elevations between 11000 and 13000 (or 11720 and 13850 English) feet, which are distinguished by the appellation of Paramos; character of their vegetation. 104-106

Notices of the two groups of mountains (Pacaraima Mountains, and 
the Sierra de Chiquitos) which separate the three plains of the Lower Orinoco, the Amazons, and the Rio de la Plata . 106-107

On the dogs of South America; both the aboriginal race and the descendants of European dogs which have become wild. Sufferings of cats when taken to elevations exceeding 13000 (13850 Eng.) feet .

. 107-112

The low tract of the Sahara, and its relations to the Atlas Mountains, according to the latest information given by Daumas, Carette, and Renou. The barometric measurements of Fournel make it appear very probable that part of the North African desert is lower than the level of the sea. Oasis of Biscara; abundance of fossil salt in zones or bands running from south-west to north-east. Causes of the nocturnal cold in the desert according to Melloni . 112-118

Notices of the River Wady Dra (1-6th longer than the Rhine, and dry a large portion of the year), and of the country of Sheikh Beirouk, a chief independent of the Emperor of Moroceo, from manuseript communications of the Naval Captain Count BouetVillaumez. The mountains north of Cape Noun (a name used by Edresi, in which, since the 15th century, an allusion to the negative particle has been erroneously sought) attain 8600 (9166 English) feet of elevation. . . . . . . . 118-120

The vegetation of the tropical American Llanos consisting of grasses, compared with the vegetation of the North Asiatic Steppes consisting of herbaceous plants. In the last-named Steppes, and especially the more fertile among them, a pleasing effect is produced in spring by small snow-white and red-flowering Rosacex, Amygdaleæ, species of Astragalus, Crown Imperials, Cypripedias, and Tulips. Contrast with the desolate salt Steppes full of Chenopodiaceæ, species of Salsola and Atriplex. Considerations on the 
relative numbers of the prevailing families of plants. The plains adjoining the Icy Sea, north of the limit determined by Admiral Wrangel as that of the growth of Coniferæ and Amentaceæ, are the domain of cryptogamous plants. Aspect and physiognomy of the Tundras, where the soil, which is perpetually frozen, is covered either with a thick coating of Sphagnum and other mosses, or with the snow-white Cenomyce and Stereocaulon paschale . 120-123

Principal causes of the very different distribution of temperature in the European and American Continents. Direction and curvature of the isothermal lines, or lines of equal temperature, for the entire - year, for the winter, and for the summer . . . 123-136

Are there any grounds for believing that America emerged later than the Old Continent from the chaotic watery covering? . 136-139

Thermic comparison of the Northern and Southern Hemispheres in high latitudes . . . . . . . . . . . . . . .

Apparent connection of the African sea of sand with those of Persia, Kerman, Beloochistan, and the interior of Asia. On the western part of Mount Atlas, and the connection of purely mythical ideas with geographical traditions. Indistinct allusions to igneous eruptions. Triton Lake. Crater-like forms of a locality south of Hanno's "Bay of the Gorilla Apes." Singular description of the "hollow Atlas" from the Dialexes of Marinus Tyrius . 143-149

Notices respecting the Mountains of the Moon (Djebel al-Komr) in the interior of Africa by Reinaud, Beke, and Ayrton. Werne's instructive notice of the second expedition undertaken by the orders of Mehemet Ali. The Abyssinian mountains, which rise, according to Rüppell, almost to the height of Mont Blanc. The most ancient notice of snow between the tropics contained in the Inscrip. 
tion of Adulis, which is somewhat more modern than Juba. High mountains which, between $6^{\circ}$ and $4^{\circ}$ of north latitude, and still more to the south, approach the Bahr el-Abiad. A considerable swelling of the ground divides the White Nile from the basin of the Goschop. Line of separation between the waters which flow to the Mediterranean and those which flow to the Indian Ocean according to Carl Zimmermann's map. Lupata Chain according to the instructive researches of Wilhelm Peters . . 149-158

Oceanic currents. In the northern part of the Atlantic Ocean the waters are impelled in a true revolving current. That the first impulse which causes the Gulf Stream is to be sought at the southern extremity of Africa, was already known to Sir Humphry Gilbert in 1560. Influence of the Gulf Stream on the climate of Seandinavia. How it contributed to the diseovery of America. Instances of Esquimaux who, aided by the returning eastward flowing portion of the warm Gulf Stream, and by north-west winds, arrived on the coasts of Europe. Such a case related by Cornelius Nepos and Pomponius Mela (of Indians given by a king of the Boii to Quintus Metellus Celer, Proconsul of Gaul); others in the time of the Othos and of Frederic Barbarossa, of Columbus and of Cardinal Bembo. Again, in the years 1682 and 1684 natives of Greenland appeared in the Orkneys . . . . . 159-165

Operation of lichens and other Cryptogamia in the cold and temperate zones in preparing the way for the more rapid establishment of larger phænogamous plants. Within the tropics lichens are often replaced in this respect by succulent plants. Milk-yielding animals of the New Continent; the Lama, the Alpaca, the Guanaco.

$165-169$

Cultivation of farinaceous grasses . $.169-173$

On the earliest population of America $.173-174$ 
The coast nation of the Guaranis (Warrans), and the Mauritia palm of the coasts, according to the accounts given by Bembo in the Historiæ Venetæ, and those of Raleigh, Hillhouse, and Robert and Richard Schomburgk .

. 174-182

Phenomena which long-continued drought produces in the Steppe; sand-spouts, hot winds (Mirage); awakening of crocodiles and tortoises from long summer sleep . . . . 182-190

Otomacs. General considerations on the practice of earth-eating among particular nations or tribes. Clays and earths containing Infusoria . . . . . . . . . 190-196

Figures graven on rocks throughout a zone running from east to west, and extending from the Rupunuri, Essequibo, and the Pacaraima Mountains, to Caycara and the wildernesses of the Cassiquiare. Earliest notice (April 1749) of these traces of former civilization in the manuscript account of the travels of the surgeon Nicolas Hortsmann of Hildesheim, found among D'Anville's papers. 196-203

The vegetable poison Curare or Ourari .' . . . 203-204

$$
\text { Cataracts of the Orinoco-p. } 207 \text { to p. } 231 .
$$

The Orinoco; general view of its course. Ideas excited in Columbus on seeing its embouchure. Its unknown sources are east of the Mountain of Duida and the groves of Bertholletia. Causes of the principal bends of the river. . . . . . 207-219

The falls or rapids; Raudal of Maypures enclosed by four streams. Former state of the district. Island-like form of the rocks Keri and Oco. Grandeur of the view obtained on descending the hill of Manimi, where a foaming river-surface of four miles in extent presents itself at once to the eye. Iron-black masses of rock rise like 
castles from the bed of the river; the summits of the lofty palm trees pierce through the cloud of spray and vapour $\quad$. 219-226

Raudal of Atures; numerous islands; rocky dikes connecting one island with another, and the resort of pugnacious golden Pipras. Parts of the bed of the river at the cataracts are dry, from the waters having found a passage by subterranean channels. We visited the rocks at the elosing in of night and during storm and heary rain. Unsuspected proximity of crocodiles .

. $226-227$

Celebrated cave of Ataruipe, the sepulchral vault of an extinct nation

$.227-231$

\section{Scientific Elucidations and Additions-p. 233 to p. 255.}

The river-cow (Trichecus manati) lives in the sea at the place where, in the Gulf of Xagua, on the south coast of the Island of Cuba, springs of fresh water break forth . . . . 233-234

Geographical discussion on the sources of the Orinoco . 236-241

The Bertholletia, a Lecythidea, a remarkable example of highly developed organization. Stem of an Arundinarea sixteen to seventeen feet long from knot to knot. . . . . . 241-243

On the myth or fable of the Lake of Parime . . . 243-254

The Nocturnal Life of Animals in the Primeval Forest-p. 259 to p. 272.

Difference between languages in respect to their richness in welldefined expressions for characterising natural phenomena, such as the state of vegetation, the forms of plants, the outlines and grouping of clouds, the appearance of the surface of the ground, and the forms of rocks and mountains. Loss which languages suffer by the disuse of such words, or by their signification becoming impaired. 
The misinterpretation of a Spanish word, "Monte," has caused the undue extension or introduction of mountains in maps. Primeval Forest; frequent abuse of the term. Absence of the uniformity which is produced by the association of the same kinds of trees, characteristic of tropical forests. Causes of the impenetrability of forests between the tropics; the twining plants, Lianes, often form only a small portion of the Underwood. . . . 259-266

Appearance of the Rio Apure in the lower part of its course. Margin of the forest fenced like a garden by a low hedge of Sauso (Hermesia). The wild animals of the forest lead their young to the river through small openings in this hedge. Flocks of large waterhogs or Cavies (Capybara). Fresh-water dolphins 266-269

Wild cries of animals resound throughout the forest. Cause of the nocturnal uproar. $\quad . \quad . \quad . \quad . \quad . \quad . \quad .269-271$

Contrast with the stillness which reigns during the noon-tide hours on days of more than usual heat in the torrid zone. Description of the narrows of the Orinoco at Baraguan. Humming and fluttering of insects. Life stirs audibly in every bush, in the clefts of the bark of trees, and in the earth undermined and furrowed by Hymenopterous insects

$.271-272$

Scientific Elucidations and Additions-p. 273 to p. 275.

Characteristic terms in Arabic and Persian deseriptive of the surface of the ground (Steppes, grassy plains, deserts, \&c.) Richness of the old Castilian idiom in words expressive of the form of mountains. Fresh-water skates and dolphins. In the great rivers of both continents some organic sea-forms are repeated. American nocturnal monkeys, the three-striped Douroucouli of the Cassiquiare. 


\section{Hypsometric Addenda-p. 277 to p. 285.}

Pentland's measurements in the eastern mountain chain of Bolivia. Height of the volcano of Aconcagua according to Fitzroy and Darwin. Western mountain chain of Bolivia . . 277-279

Mourtain systems of North America. Rocky Mountains and the Snowy Chain (Sierra Nevada) of California. Laguna de Timpanogos. $279-283$

Hypsometrical profile of the Highland of Mexico from the city of Mexico to Santa Fé . . . . . . . 283-285

END OF VOL. I. 





Q

171

H863

จ.1

P\&ASci.
Humboldt, Alexander Aspects of nature

\section{PLEASE DO NOT REMOVE}

CARDS OR SLIPS FROM THIS POCKET

\section{UNIVERSITY OF TORONTO LIBRARY}




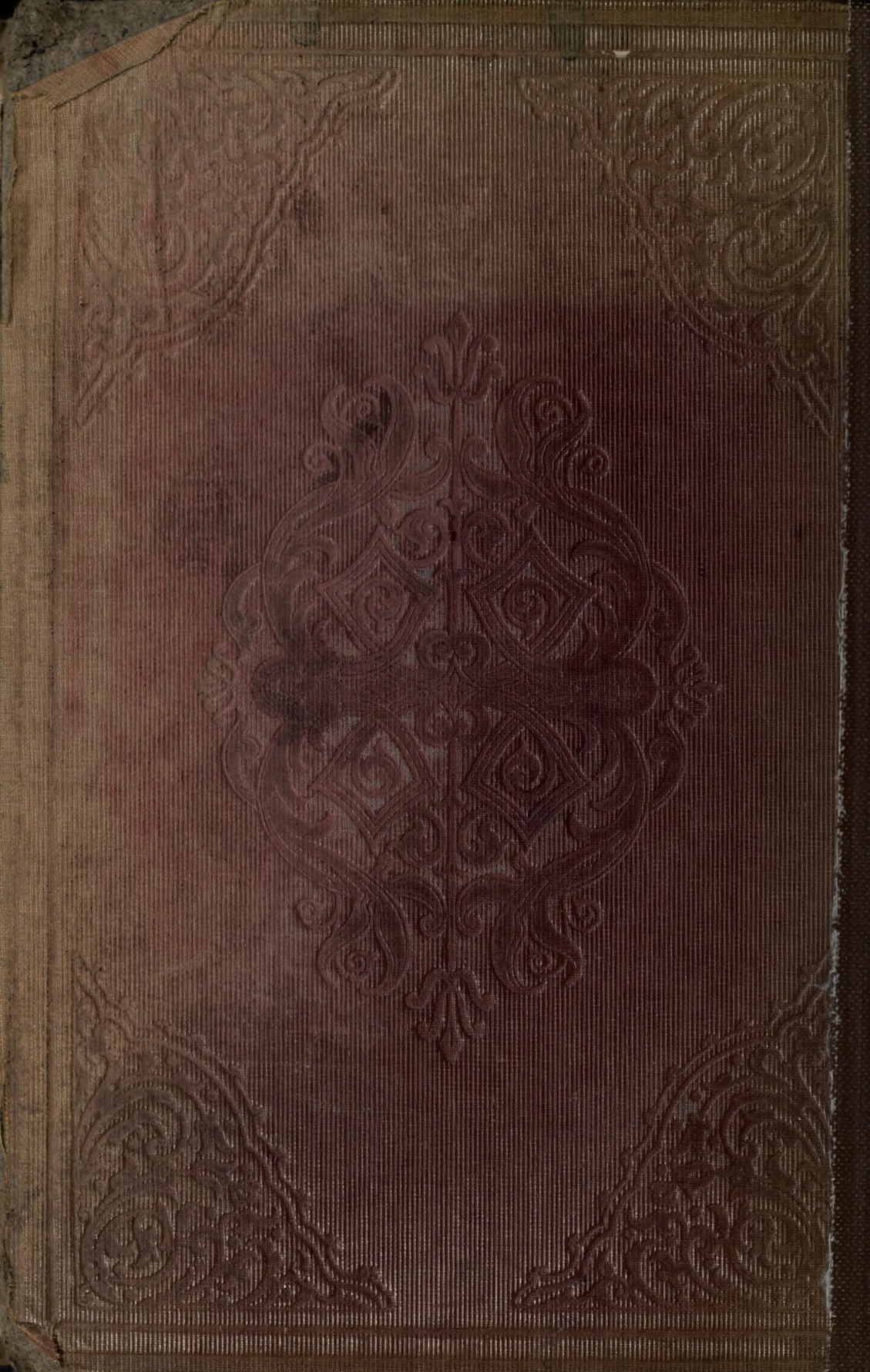

